\title{
POLÍTICAS PÚBLICAS E MERCADOS DEPRIMEM O RESULTADO DO SISTEMA AGROINDUSTRIAL DO LEITE
}

\section{PAULO DO CARMO MARTINS}

Bacharel em Ciências Econômicas

Orientador: Prof. Dr. PAULO FERNANDO CIDADE DE ARAÚJO

Tese apresentada à Escola Superior de Agricultura "Luiz de Queiroz" da Universidade de São Paulo, para obtenção do Título de Doutor em Ciências, Área de Concentração: Economia Aplicada.

PIRACICABA

Estado de São Paulo - Brasil

Dezembro - 2002 


\section{Dados Internacionais de Catalogação na Publicação (CIP) DIVISÃO DE BIBLIOTECA E DOCUMENTAÇÃO - ESALQ/USP}

Martins, Paulo do Carmo

Políticas públicas e mercados deprimem o resultado do sistema agroindustrial do leite / Paulo do Carmo Martins. - - Piracicaba, 2002.

$217 \mathrm{p}$.

Tese (doutorado) - Escola Superior de Agricultura Luiz de Queiroz, 2002.

Bibliografia.

1. Competição econômica 2. Leite 3. Política pública 4. Sistema agroindustrial Eficiência I. Título

CDD 338.177

Hermitida a copia total ou parcial deste documento, desde que citada a fonte - $\mathbf{0}$ autor" 


\section{OFEREÇO}

A meus pais, Jurandir e Maria da Conceição,

espelhos de minha trajetória de vida.

\section{DEDICO}

À companheira Lêda, presente na alegria e na tristeza, e ao Lucas, à Paula e ao Vitor, que intensamente participaram desta etapa de minha vida. 


\section{AGRADECIMENTOS}

Nas montanhas de Minas, mais que o queijo, a cachaça, a lingüiça e as letras, degusta-se Gratidão.

A Embrapa ofereceu-me oportunidade de treinamento na FGV/RJ, com o Prof. Mauro Lopes, em 1998, quando o problema da tese começou a ser gestado. Os pesquisadores Rita Milages, "Tonito" Teixeira, Antônio Jorge e a equipe de técnicos da Secretaria de Assuntos Estratégicos da Embrapa estimularam-me a desenvolver esta pesquisa e apoiaram-me no requerido.

A Universidade Federal de Juiz de Fora contemplou-me com bolsa de estudos de sua cota, da CAPES.

A Universidade de São Paulo, mais especificamente, o Departamento de Economia, Administração e Sociologia da Escola Superior de Agricultura "Luiz de Queiroz", recebeu-me e proveu-me de estímulo e das condições mais que satisfatórias para me dedicar aos meus propósitos.

As Profas. Mirian Rumenos e Ana Kassouf reintroduziram-me nos métodos quantitativos e o Prof. Joaquim Bento mostrou-me a abordagem formal da microeconomia. Revi e refleti sobre economia brasileira com o Prof. Pedro Melo. Com o Prof. Geraldo Camargo voltei a dedicar-me ao fascinante estudo 
sistemático da macroeconomia, num ambiente de estímulo e respeito marcantes. O Prof. Décio Zylbersztajn deu-me duas indeléveis contribuições. Uma, de caráter formal, com respeito ao referencial da NEI. A outra, de cunho pessoal, fez-me refletir como professor, sobre o planejamento e a condução de uma disciplina, em ambiente provocativo e de envolvente participação. Da mesma forma o Prof. Joaquim Guilhoto influenciou-me duplamente: com o instrumental adquirido e na minha conduta futura como professor. Com ele, mais que aprender, foi possivel gostar de aprender.

O Prof. Carlos Bacha foi meu orientador desde o início do curso. Com ele delimitei o trabalho da pesquisa e deu-me a segurança necessária na etapa inicial do trabalho e conduziu-me até ao Seminário de Tese. A realização do seu curso de pós-doutoramento, o que implicou em seu afastamento do Brasil, levou-nos à separação.

Convivi com o Prof. Paulo Cidade desde o primeiro minuto do curso. Com ele tive a primeira aula e fiz duas disciplinas. Ele também participou da banca de meu Seminário de Tese e substituiu o Prof. Bacha, como meu orientador. Nessa condição, foi possível estreitar os laços de convivência e perceber suas características mais acentuadas, e conhecer um pouco de sua história de vida - de formação de pessoas e estruturação de instituições públicas reconhecidas, o que o faz respeitado pelas três gerações de economistas em atividade, e pela comunidade científica brasileira.

Os profs. Pedro Marques e Zilda Mattos doaram-me conhecimento e tempo, duas variáveis sempre caras, ao lerem duas versões iniciais da pesquisa. Deram-me sugestões estruturantes, ao participarem das bancas de Seminário de Tese e de Qualificação. O Prof. Alexandre Mendonça de Barros também muito contribuiu, ao participar da Banca de Qualificação e da Banca de Defesa da Tese. 
Foi muito relevante ter contado com críticas e comentários da Profa. Elizabeth Farina (FEAJUSP), do Prof. Antônio Campos (UFV), e do Prof. Léo Ferreira (UERJ) na Banca de Tese. Os dois primeiros conheço e admiro a quase duas décadas. O Prof. Léo é, para mim, uma agradável relação conquistada recentemente.

Nestes anos de convivência, recebi mais que tratamento profissional dos colaboradores do Depto., especialmente de Maielli, Helena, Ligiana, Elenice, Álvaro, Pedro e Luciane.

Relação de longa data e de tantas jornadas, Custódio Mattos, Maria Helena Castro e José Maurício Arantes deram-me a exata noção de amizade, ao estarem presentes, apesar da distância.

Em Piracicaba, Roberto Dias, Alexandre Florindo e José Parré cuidaram de me receber carinhosamente. Forjada na labuta do dia-a-dia, a confiança e a admiração recíprocas do casal Cleise e Emerson Hilgemberg, Carlos Estevão, Marcos Hasegawa, Francisco Casimiro, Marcia Istake e Ricardo Lopes ensinaram-me, dentre outras, como é fundamental a partilha e a construção coletiva. Do contato como colega em sala de aula surgiram relações mais fortes também com Sérgio De Zen, Arlélio dos Santos e Alexandre "Conchas".

Não fosse uma história de dedicação, por mais de duas décadas, de de profissionais engajados e reconhecidos, a Embrapa Gado de Leite não poderia ter cumprido o papel de melhor cartão de visitas junto às empresas de laticínios e aos produtores, o que viabilizou o trabalho de coleta de informações. Não fosse também a decisão de seus dirigentes, Duarte Vilela e Mário Martinez, no sentido de viabilizar recursos, a obtenção de informações poderia não ter ocorrido da forma segura como ocorreu. 
Aloísio Gomes foi meu Conselheiro Acadêmico pela Embrapa. Rui Verneque evitou que eu cometesse erros estatísticos no trabalho. Luiz Carlos Takao e Alziro Carneiro, percorri $31.840 \mathrm{~km}$ por via terrestre, visitando fazendas e fábricas de leite, em cinco estados da Federação. Além disso, contei com eles, em jornadas de 15 horas diárias, durante vários dias, na limpeza e entrada dos dados coletados. Paulo Moreira viabilizou os primeiros contatos em Goiás, que resultaram nas coletas de informações.

Também o Takao e o Prof. Ricardo Martins foram muito importantes e, em alguns momentos, decisivos, nas sugestões que fizeram. Contei ainda com amizade fraternal de Guilherme Martins e vali-me de sua inteligência, sua paciência e, literalmente, suas mãos, pois ele soube conviver com minha irritação e desânimo temporários quando, durante cinco meses e por motivos de doença, fiquei impossibilitado de utilizar as minhas próprias mãos.

O Drs. Ernesto Krug, Antonio Carlos Souza e Braz Neves deram-me segurança necessária, gerando e corrigindo informações relativas ao segmento industrial lácteo, não disponiveis na literatura. Sem elas, seria impossivel estudar cadeias de leite em pó e de leite longa vida. O Prof. Vidal e o Dr. Vicente Nogueira também forneceram-me preciosas informações.

Os Drs. Edson Gonçalves, Edimilson Vilela, Ernesto Krug, Valter Galan, Eduardo Portugal, Loreno Taffarel, Arnaldo Bandeira, Manolo e Jacques Gontijo se responsabilizaram, com suas equipes, por toda a operação logística que possibilitou-me estar nas propriedades amostradas, sem perda de tempo.

As empresas Parmalat, Coonai, Elegê, Castrolanda, Frimesa/Sudcoop, Centroleite, Itambé e Nestlê cederam recursos e técnicos, vitais para a coleta de dados. 


\section{SUMÁRIO}

Página

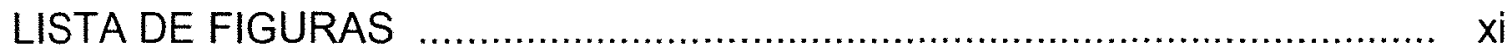

LISTA DE QUADROS .................................................................. xiii

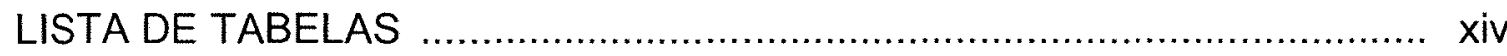

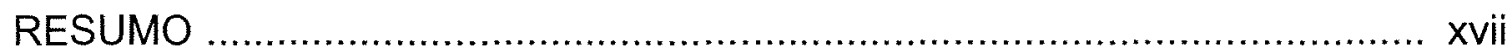

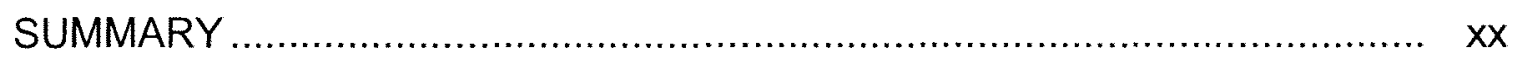

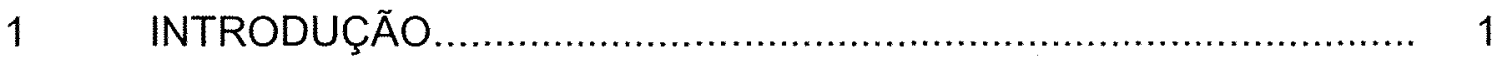

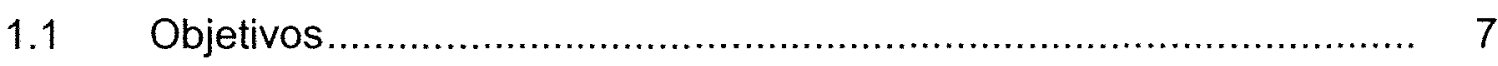

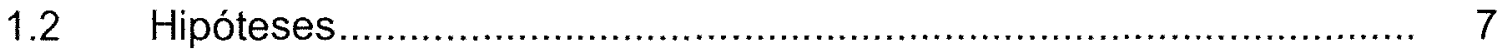

1.3 Organização do trabalho ........................................................ 8

2 SAG DO LEITE NO BRASIL: UMA REVISÃO E ANÁLISE

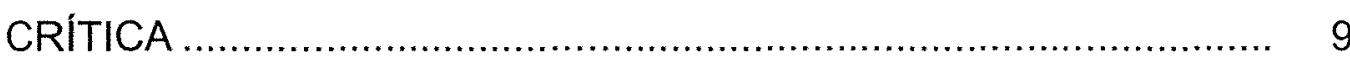

2.1 Evolução do setor de leite e laticínios …...................................... 9

2.1.1 Período da regulamentação ....................................................... 9

2.1.2 Período pós-desregulamentação.................................................. 11

2.1.2.1 Transformações no SAG do leite nacional .................................... 11

2.1.2.2 Relação produtor - indústria.................................................... 12

2.1.2.3 Comércio internacional e o SAG do leite nacional ......................... 13

2.2 Relevância do SAG do leite no contexto da economia

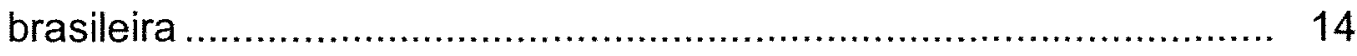

2.3 Transformações no SAG do leite após a desregulamentação ......... 19

2.3.1 Segmento produção ................................................................. 19

2.3.2 Segmento transporte até a usina de processamento .................... 24 


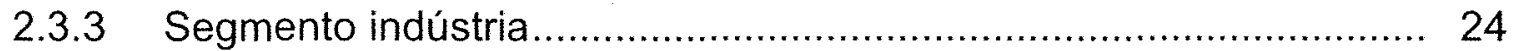

2.3.4 Segmento distribuição/varejo ................................................... 29

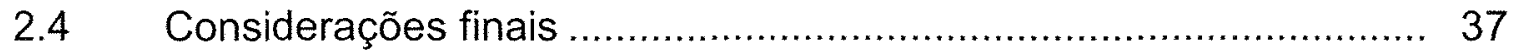

3 MERCADO INTERNACIONAL DE LÁCTEOS E O ACORDO AGRICOLA DA OMC: UMA REVISÃO ANALÍTICA …................... 40

3.1 Justificativas para a regulamentação ............................................ 41

3.2 Mercado internacional de lácteos ............................................. 45

3.3 Rodada Uruguai e a implementação do Acordo Agrícola em países e regiões selecionados ..................................................... 51

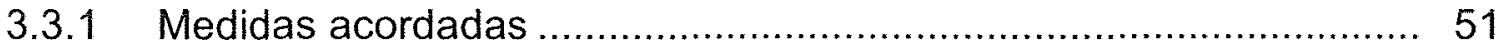

3.3.1.1 Acesso a mercados .............................................................. 52

3.3.1.2 Medidas de apoio interno ..................................................... 53

3.3.1.3 Estímulo à exportação ............................................................ 54

3.4 Politicas de regulamentação e o Acordo Agrícola por países e regiões selecionados ................................................................ 54

3.4.1 Estados Unidos da América ..................................................... 54

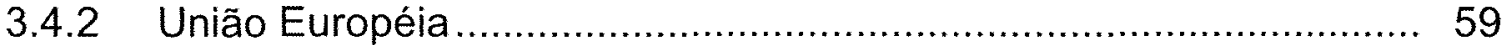

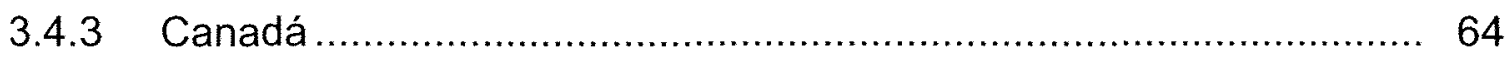

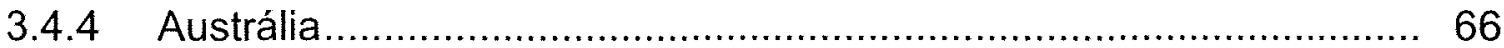

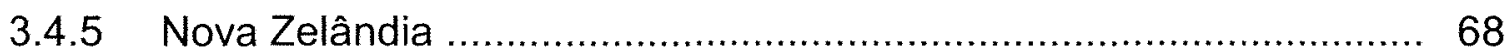

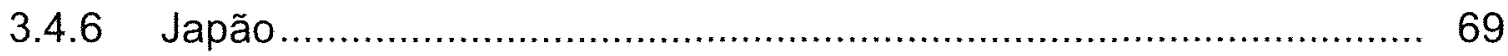

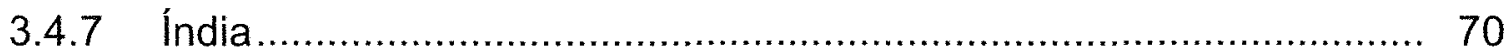

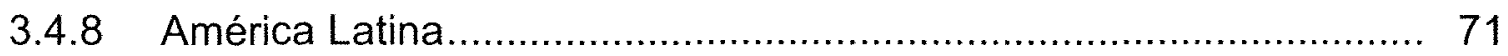

3.5 Simulações sobre a desregulamentação no mercado de

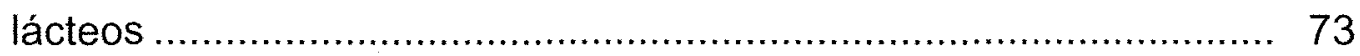

3.6 Considerações finais ............................................................. 77

4 RESULTADO ECONÔMICO DA ATIVIDADE E VISÃO INSTITUCIONAL DOS PRODUTORES …..................................... 80

4.1 Economia dos custos de transação .............................................. 81

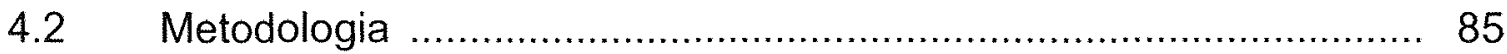


4.2.1 Fonte de dados e procedimentos adotados ................................ 89

4.3 Análise de resultados entre corredores ...................................... 92

4.4 Considerações finais ................................................................ 117

5 IMPACTO DE POLITICAS PÚBLICAS E FALHAS DE MERCADO NO SAG DO LEITE .............................................. 120

5.1 Matriz de Análise Política ...................................................... 121

5.2 Operacionalização da MAP ..................................................... 130

5.3 Aplicações da MAP ................................................................ 140

5.3.1 Segmento de produção ......................................................... 140

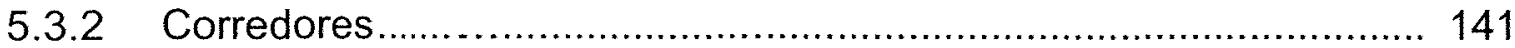

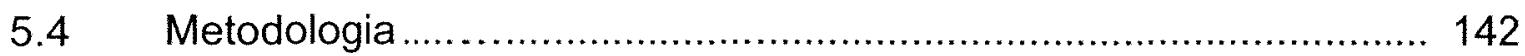

$5.5 \quad$ Resultados da MAP ............................................................... 145

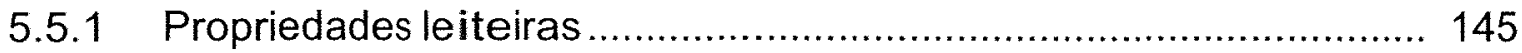

5.5.2 Leite Longa Vida................................................................... 149

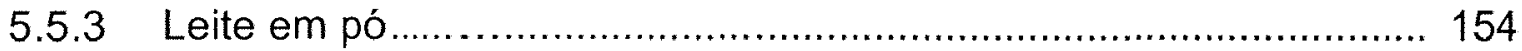

5.5.4 Análise de sensibilidade ........................................................ 157

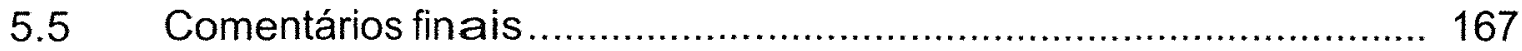

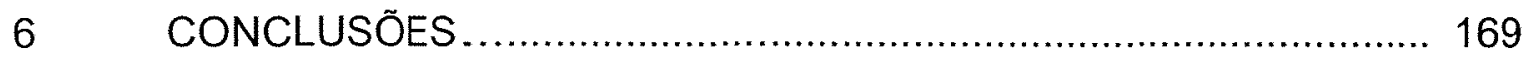

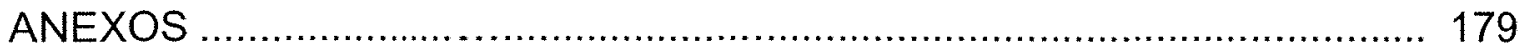

REFERÊNCIAS BIBLIOGRÁFICAS ............................................. 203 


\section{LISTA DE FIGURAS}

Página

1 Preços reais mensais recebidos por produtores de leite em cinco estados, Brasil, Janeiro de 1986 a Agosto de 2001

2 Preços recebidos por produtores de leite, média dos cinco estados maiores produtores, expressos em dólar americano, Brasil, Janeiro de 1986 a Agosto de 2001

3 Dispêndio anual em Reais estimado com Leite, Leite Fluido, Leite em Pó e Demais Derivados em Regiões Metropolitanas Selecionadas, Brasil, 1995-1996 34

4 Percentagem do dispêndio com leite por produto, por RM, Brasil, 1996 36

5 Dispêndio mensal e per capita com leite e derivados em onze $\mathrm{RM}$, em Reais e em percentual relativo ao dispêndio com alimentos, por classe de renda

6 Instituições e desempenho econômico 84

7 Determinantes das instituições formais 85

8 Fluxograma de apropriação de custos por setores 87

9 Produtores sindicalizados e conhecimento de medidas adotadas pelo Governo que afetaram o SAG do leite, por corredor 
10 Instituições que representam os interesses dos produtores.

Respostas expontâneas e múltiplas

11 Opinião sobre o trabalho desenvolvido pela CNA na defesa dos interesses dos produtores, por corredor

12 Opinião sobre o trabalho desenvolvido pela Leite Brasil na defesa dos interesses dos produtores, por corredor

13 Opinião sobre o trabalho desenvolvido pela Indústria de laticinios na defesa dos interesses dos produtores, por corredor.

14 Opinião sobre o trabalho desenvolvido pelo Poder Executivo na defesa dos interesses dos produtores, por corredor.

15 Opinião sobre o trabalho desenvolvido pelo Poder Legislativo na defesa dos interesses dos produtores, por corredor

16 Opção de voto dos produtores em candidatos ao Legislativo Federal em 1998, por corredor

17 Opção de voto dos produtores em candidatos ao Legislativo Estadual em 1998, por corredor

18 Fronteira de Possibilidades de Produção

19 Efeitos de políticas na MAP 128

20 Lucros consolidados e a partição entre produtores e demais elos da cadeia produtiva do Leite Longa Vida, por mil litros, por corredor.

21 Lucros consolidados e a partição entre produtores e demais elos da cadeia produtiva do Leite em pó, por mil litros, por corredor. 


\section{LISTA DE QUADROS}

Página

1 Estados, corredores e municipios participantes da pesquisa

2 Produção diária, preço do leite, resultado econômico, área usada em leite e preço da terra, por corredor, Agosto/2000 a Julho/2001

3 Resultado econômico: custos de produção, preço do leite e lucro por mil litros de leite, por corredor. Agosto/2000 a Julho/2001 $(\mathrm{R} \$ 1,00)$.

4 Conhecimento, pelos produtores, de critérios de bonificação adotados e suas preferências, por corredor

5 Comparação de mensuração de efeitos de políticas entre matriz de análise política e modelo de equilíbrio parcial.

6 Matriz de Análise Política-MAP

7 Custos consolidados, receita e lucro da cadeia produtiva do leite Longa Vida, por 1.000 litros, por corredor, Agosto/2000 a Julho/2001, (R\$1,00)

8 Custos consolidados, receita e lucro da cadeia produtiva do Leite em pó, por mil litros, por corredor, Agosto/2000 a Julho/2001 (R\$ $1,00)$ 


\section{LISTA DE TABELAS}

Página

1 Estimativa de geração de emprego, renda e tributos para um aumento de demanda de $\mathrm{R} \$ 1$ Milhão, em setores selecionados

2 Índices de Ligação de Rasmussen-Hirschman por Setores Selecionados, Brasil, 1996

3 Produção de leite e distribuição percentual por regiões, Brasil, 1990-2000 (milhões de litros)

4 Os cinco estados da Federação maiores produtores de leite, Brasil, 1990-2000 (bilhões de litros).

5 Estimativa de Taxa Anual de Crescimento -T.A.C. da produção, vacas ordenhadas e produtividade, por décadas, Brasil, 19701999 (\% ao ano)

6 Número de unidades fornecedoras dos doze principais laticínios, Brasil, 1996-2000 (em mil unidades)

7 Volume diário de leite recebido por produtor em doze dos principais laticínios, Brasil, 1996-2000 (em litros)

8 Produção e importação de derivados lácteos anuais em equivalente leite, Brasil, 1970-1999

9 Consumo de leite fluido, Brasil, 1990-99 (milhões litros).

10 Dispêndio mensal per capita estimado com alimentação e leite por Região Metropolitana, Brasil, 1996.

11 Principais países produtores de leite, 1999 
12 Maiores exportadores líquidos em equivalente leite, 1999 ................. 48

13 Maiores importadores líquidos em equivalente leite, 1999 ................. 48

14 Subsídio Equivalente ao Produtor de leite em países da OCDE ......... 49

15 Comportamento da produção de leite por regiões, 1992-1994 ............ 50

16 Consumo per capta de leite em litros por regiões, 1983-1994 ............. 51

17 Efeitos do livre comércio sobre os preços de derivados lácteos .......... 75

18 Efeitos sobre o bem-estar da liberação do comércio lácteo: (US\$

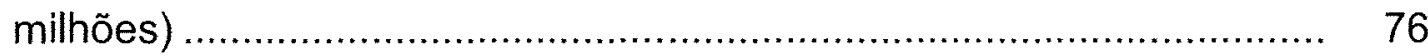

19 Variação percentual de preços e quantidades para leite cru e leite processado, com a retirada de cotas de produção, por países

20 Produção, receita e preços de terra e de vaca por corredor, Agosto/2000 a Julho/2001

21 Grau de Sangue das vacas e adoção de aleitamento artificial, por corredor, Agosto/2000 a Julho/2001

22 Indicadores de Eficiência por corredor, Agosto/2000 a Julho/2001

23 Características da posse da terra e do uso de mão-de-obra, por corredor, Agosto/2000 a Julho/2001

24 Indicadores sócio-econômicos por corredor, Agosto/2000 a Julho/2001

25 Opinião dos produtores sobre práticas de preços diferenciados e adoção de contratos formais de comercialização, por corredor

26 Preferência de produtores quanto ao critério de bonificação a ser valorizado, por corredor 106

27 Indicadores privados e sociais de propriedades leiteiras por litro de leite, por corredor

28 Indicadores privados e sociais da cadeia produtiva do leite Longa Vida, por corredor

29 Indicadores privados e sociais da cadeia produtiva do leite em 
Pó, por corredor

30 Variação na Razão do Custo Doméstico da cadeia produtiva do leite Longa Vida, quando ocorre variação de $1 \%$ no valor dos fatores, preço de venda e na produtividade, por corredor 159

31 Variação na Razão do Custo Doméstico da cadeia produtiva do Leite em Pó quando ocorre variação de $1 \%$ no valor dos fatores, preço de venda e na produtividade, por corredor 160

32 Variação na Razão do Custo Privado da cadeia produtiva do leite Longa Vida quando ocorre variação de $1 \%$ no valor dos fatores, preço de venda e na produtividade, por corredor 162

33 Variação na Razão do Custo Privado da cadeia produtiva do Leite em Pó quando ocorre variação de $1 \%$ no valor dos fatores, preço de venda e na produtividade, por corredor

34 Indicadores de competitividade e de eficiência para as cadeias produtivas de Leite Longa Vida e Leite em Pó, por corredor

35 Preços de comercialização em São Paulo, os quais a competitividade e a eficiência são anuladas, cadeias produtivas de Leite Longa Vida e Leite em Pó, por corredor 


\title{
POLÍTICAS PÚBLICAS E MERCADOS DEPRIMEM O RESULTADO DO SISTEMA AGROINDUSTRIAL DO LEITE
}

\author{
Autor: PAULO DO CARMO MARTINS \\ Orientador: Prof. Dr. PAULO FERNANDO CIDADE DE ARAÚJO
}

\section{RESUMO}

Esta pesquisa teve como objetivo analisa a competitividade e a eficiência nos principais corredores do Sistema Agroindustrial do Leite no Brasil. Para tanto, estudaram-se diferenças de regulamentação do leite nos principais mercados domésticos e suas conseqüências sobre o mercado internacional, pois o Brasil coloca-se como histórico importador do produto. Investigou-se também, em diferentes economias, como políticas de regulamentação foram impactadas em função do Acordo Agrícola implementado pela Organização Mundial do Comércio. Além disso, aferiu-se o custo econômico exclusivamente da produção de leite em propriedades e em cadeias produtivas e diagnosticaram-se a competitividade e a eficiência em propriedades, e na produção de Leite em Pó e leite Longa Vida, por corredor. Foram coletados dados em propriedades dos estados de Goiás, Minas Gerais, São Paulo, Paraná e Rio Grande do Sul. Apurou-se o custo da atividade, em 
cada propriedade leiteira, separando-se o custo de recria de fêmeas do custo de produção de leite, pois a atividade gera, ao final, os dois produtos. Os produtores também foram levados a se posicionar quanto a organização institucional do setor. A avaliação sobre competitividade e eficiência deu-se pelo uso do instrumental Matriz de Análise Política. Nos países analisados a atividade mostrou-se muito regulamentada, em geral com o propósito de atender os interesses dos produtores, que contam com instrumentos de proteção e estímulo. Como conseqüência, o mercado internacional de lácteos apresenta importantes distorções. O Acordo Agrícola não foi suficiente para promover grandes transformações nesse cenário. Quanto ao Brasil, Verificouse que o sistema agroindustrial do leite é muito importante na geração de emprego, renda e tributos, em comparação com outros setores da economia. A abertura econômica e a desregulamentação do setor trouxeram dinamismo à atividade, mas acentuou a concentração em diferentes segmentos da cadeia produtiva. Os diferentes corredores analisados mostraram importantes diferenças em termos de procedimentos produtivos e de organização, entre regiões e entre produtores de um mesmo corredor. Isso impossibilita afirmar que haja padronização de sistemas de produção. Por outro lado, os produtores pesquisados demonstraram que conhecem pouco as instituições que os representam. O percentual de filiados a sindicatos é baixo e poucos acompanham medidas tomadas pelo Governo que interferem em sua atividade. A maioria votou em candidatos ao Legislativo não identificados com o leite, mas, contraditoriamente, mostrou-se insatisfeitos com a atuação desse Poder. Todos os 150 produtores e as duas cadeias produtivas (leite Longa Vida e Leite em Pó) foram eficientes em niveis aceitáveis. A maioria dos produtores e todas as cadeias produtivas mostraram-se competitivas. Identificaram-se distorções, geradas por falhas de mercado e por politicas de governo, que impactaram as propriedades e as cadeias produtivas. Discriminam contra os produtores, em maior magnitude. Entre as cadeias, a mais desprotegida é a do leite em pó. A cadeia do leite longa vida demonstrou pequena desproteção. 


\title{
PUBLIC POLICIES AND MARKETS REDUCE THE RESULTS IN THE DAIRY AGRIFOOD SYSTEM
}

\author{
Author: PAULO DO CARMO MARTINS \\ Adviser: Prof. Dr. PAULO FERNANDO CIDADE DE ARAÚJO
}

\section{SUMMARY}

This research had as general objective to identify the competitiveness and the efficiency in the main aisles of the Brazilian Dairy Agrifood System. To enable that, differences in the dairy regulation in the main domestic markets and its consequences upon the international market was studied, since Brazil in the position of historical importer of the product. How regulation were affected by the Agricultural Agreement, implemented by the World Trade Organization, was also researched in different economies. Beyond that, only in properties and productive chains the economic cost of the milk production was taken into account, finding competitiveness and efficiency in the properties, as well as in powdered and Ultra High Temperature (UHT) milk production, in each "aisle". Data were collected in 150 farms located in the states of Goiás, Minas Gerais, São Paulo, Paraná and Rio Grande do Sul. The average cost of the activity was calculated in each farm milk system, separating the females breeding cost from 
milk production cost, as the whole activity results in these two products. The producer were also positioned in institutional organizations of the sector. The evaluation about competitiveness and efficiency was done by the use of the Policy Analysis Matrix methodology. In the countries studied the activity presented itself as being strongly regulated, in general with the purpose of attending producers interests, aiming on protection and incentives goals. As a consequence, the dairy international market presents important distortions. The Agricultural Agreement was not enough to promote great changes in this scenario. As far as Brazil is concerned, it was verified that the milk agrifood system is very important when the creation of employment, income and taxes are taken into account, especially when compared to other sectors of the economy. The economica adn trade liberalization of the brazilian economy land the lack of regulation in the sector brought dynamism to the activity, but increased the concentration in different branches of the productive chain. The different "aisles" analyzed showed important differences in terms of productive procedures and of organization, among regions and even among producers of the same "aisle". This makes it impossible to affirm that there is a standardization in the production systems. On the other hand, the researched producers did not seem to know the institutions by which they are represented very well. The percentage of syndicate members is low and only a few follow the government measures which interfere in their activity. The majority voted for candidates to the Legislative who are not identified with milk problems, but in contradiction, showed no satisfaction with most of Congress attitudes and decisions. All the producers and the two productive chains they discriminate. Most producers and all the productive chains were competitive. Distortions were identified, created by market improjections and by government policies, which had a great impact on the farms and productive chains. Tehy discriminate against milk producers, in greater magnitude. Among the chains, the least protected is the one of powdered milk. The UHT chains did not show much lack of protection. 


\section{INTRODUÇÃO}

O presente trabalho analisa a competitividade e a eficiência do Sistema Agroindustrial - SAG do leite em dez dos principais corredores do Brasil. O problema motivador foi o seguinte: a possível existência de distorções geradas por políticas públicas e falhas de mercado propiciam impactos diferenciados em distintas regiões produtoras de leite e de derivados no Brasil?

Para tanto, foram utilizados os conceitos a seguir. Corredor agrega a visão de eixos, pólos e clusters, numa análise que integra áreas com desenvolvimento local em estágios diferentes, com potenciais diferentes e eventualmente unidos por cadeias produtivas comuns (Nasser, 2000). Especificamente, considera-se uma região produtora de leite em um estado da Federação, o transporte até à usina de beneficiamento, o processamento e o transporte do produto processado até ao local de comercialização. Cluster consiste de indústrias e instituições que têm ligações entre si, tanto horizontal quanto verticalmente, incluindo empresas de transformação, de fornecimento, prestadoras de serviço, instituições de pesquisa e de suporte, públicas e privadas (Haddad, 1999).

Por Sistema Agroindustrial entende-se a reunião dos participantes envolvidos na produção, processamento e marketing, o que inclui suprimento, processamento, atacado e varejo, envolvidos em um fluxo desde a produção de insumos até o consumidor final. Inclui instituições que afetam e coordenam os estágios sucessivos do fluxo do produto, tais como Governo e associações (Golberg, citado por Neves \& Spers, 1996). 
Competitividade é a capacidade que os sistemas produtivos têm de conseguirem sustentar ou ampliar, duradouramente, suas posições competitivas no mercado (Silva \& Batalha,1999). É a capacidade sustentável de sobreviver e, de preferência, crescer nos mercados concorrentes ou em novos mercados.

Eficiência pode-se caracterizar como eficiência técnica - a escolha de uma combinação de insumos leva ao mais alto nível de produto, dada a tecnologia disponível; eficiência econômica - dado um conjunto de insumos e preços de insumos e produto, extrai-se a produção economicamente "ótima"; e eficiência social - dada pela impossibilidade de rearranjar a disponibilidade de bens, visando elevar o bem-estar de um agente, sem que haja redução de bemestar de outrem (Tsakok, 1990).

Nos diferentes países o SAG do leite é regulamentado. Visa-se a conjugação de um ou mais interesses, como a segurança alimentar, a preservação de renda dos agentes produtivos, a preservação da renda dos consumidores e/ou a obtenção de divisas no mercado internacional.

Leite é, portanto, assunto de Estado. As diferentes formas de regulamentação, somados aos desenhos de políticas macroeconômicas em cada país, impactam os mercados domésticos de maneira distinta, refletindo no mercado internacional de derivados lácteos. Como conseqüência, a competitividade e a eficiência dos corredores são também impactados.

No Brasil, o SAG do leite tem importância significativa. Está presente em todo o território nacional e gera renda e um grande contingente de postos de trabalho. Em 1996 movimentou R\$ 17,34 bilhões, em valor de mercado, subtraídos os impostos indiretos e margens de transporte e de comercialização, ou seja, até o portão do laticínio (Instituo Brasileiro de Geografia e Estatística IBGE, 2000a). Desse montante, $54 \%$ corresponderam ao consumo lácteo pelas 
familias, enquanto o restante foi utilizado como insumo em produtos e serviços ofertados pelos demais setores da economia brasileira. Leite é, portanto, insumo para diferentes atividades produtivas.

Em 1996, a indústria de laticínios gerou 65,4 mil empregos diretos. Mas é na atividade primária que o maior volume de empregos é gerado. Em 1995, cerca de 1,8 milhão de propriedades agrícolas produziram leite (IBGE, 2000b). Assumindo-se um mínimo de dois trabalhadores atuando continuamente por propriedade, esse segmento gerou pelo menos 3,6 milhões de postos de trabalho permanentes (Martins \& Guilhoto, 2001).

A regulamentação da produção de leite no Brasil data de 1945, época em que o Governo Federal exercia rigoroso controle de preços sobre um conjunto de produtos considerados de primeira necessidade. A proteção aos consumidores foi a tônica da intervenção ao longo de 46 anos e acentuou-se na década dos oitenta, quando o controle do custo de vida mereceu maior atenção, face ao recrudescimento das taxas de inflação. A utilização do controle do preço deveu-se ao elevado peso relativo que leite e derivados apresentam no índice de custo de vida - cerca de $4 \%$ nos índices calculados nas regiões metropolitanas, para população com faixa de renda de até dez salários mínimos.

O resultado da experiência de regulamentação do mercado de leite e derivados nacionais não foi favorável ao crescimento e modernização do SAG do leite. Perpetuaram-se baixas taxas de crescimento da produção, baixos índices zootécnicos, pouca especialização do rebanho e restrita adoção de práticas higiênico-sanitárias. Adicionalmente, houve elevada instabilidade de preços recebidos pelos produtores entre anos e entre meses de um mesmo ano, o que redundou em fator inibidor de investimentos em modernização tecnológica. Por outro lado, as importações de leite feitas pelo governo, nem 
sempre no momento e nas quantidades necessárias, gerou até mesmo situações de excesso de oferta de leite na entressafra e a escassez na safra.

A década de noventa iniciou-se com transformações institucionais na economia brasileira. A busca por maior inserção no cenário internacional, a formalização do Mercosul e a implementação do chamado Plano Real ocorreram num ambiente em que o Governo Federal, visando ao controle das taxas inflacionárias e à modernização produtiva, procurou desregulamentar a economia. Some-se a isso o fato da Constituição Federal, promulgada em 1988, ter como marcante característica a descentralização de competências e de responsabilidades, entre os três niveis de poder.

No SAG do leite, essas mudanças institucionais foram sentidas com bastante intensidade. Em 1991 o Governo Federal deixou de fixar preços e de definir importações. A desregulamentação se deu no momento em que se promovia a consolidação do Mercosul, e a abertura comercial, esta de forma mais ampla. Por outro lado, a implementação do Plano Real, que minimizou o imposto inflacionário, estimulou o consumo e a diversificação na produção de lácteos.

Os reflexos dessas mudanças no ambiente competitivo fizeram com que a década dos noventa guardasse um contraste com o que se verificou nos 46 anos anteriores de intervenção governamental. Aumentou a produção de leite entre 1990 e 1999 - com destaque para a região Centro-Oeste, aumentou a concentração industrial e o mercado de lácteos tornou-se dinâmico.

De fato, as mudanças no cenário macroeconômico ensejaram mudanças no comportamento dos agentes integrantes da cadeia produtiva do leite. No período da regulamentação plena, as atenções estiveram voltadas para o custo de produção nas propriedades - parâmetro para a reinvidicação de preços junto ao Governo. A partir daí organizava-se a cadeia, com pouca 
competição e dinamismo. Após 1991 e principalmente após 1994, o mercado consumidor passou a ser o ponto de referência e indutor de dinamismo.

Este novo cenário tem por característica a seleção contínua de produtores e laticínios que permanecem no mercado. Representantes de produtores têm argumentado que as condições vigentes nos países exportadores dificultam a plena competição do produto nacional com o produto importado. Após dois anos de intensa negociação, o que em alguns momentos desgastou as relações do Brasil com Argentina e Uruguai, fechou-se um acordo no âmbito do Mercosul, exatamente para evitar a chamada "triangulação", ou seja, a entrada no Brasil de produtos lácteos subsidiados e originários de países que não participam deste bloco, via Argentina e Uruguai, usufruindo das condições favoráveis de comércio. Adicionalmente, em 2001, o Brasil passou a adotar imposto "ad valorem" diferenciado, com alíquotas variando em função do país de origem, como estratégia anti-dumping.

Um outro tópico que compromete a competição do produto nacional com o importado está relacionado à carga tributária. Apenas com ICMS foram arrecadados $R \$ 2,11$ bilhões em 1996, o que correspondeu a $4,1 \%$ do total arrecadado em toda a economia com este imposto, apesar do sistema lácteo ter movimentado $1,3 \%$ do total do faturamento da economia, com base em dados do IBGE (2000a).

A elevada incidência de tributos sobre os lácteos é um dos fatores a explicar o comprometimento de mais de US\$ 2 bilhões em importações de lácteos na segunda metade da década passada. Com efeito, enquanto países exportadores adotam políticas no sentido de isentar de impostos e até mesmo reduzir o preço dos produtos lácteos destinados ao mercado internacional, no Brasil os lácteos são onerados significativamente. Por ser este um imposto de base estadual, todavia, os integrantes da Federação têm adotado políticas diferentes quanto ao ICMS incidente no SAG do leite. 
Quanto às negociações entre produtores e indústria, o custo de produção é peça fundamental. Sua obtenção é, contudo, procedimento de difícil consecução, dada a complexidade das atividades necessárias ao processo produtivo e as alternativas de alimentação, uso de medicamentos, e demais ações relacionadas ao manejo do rebanho, o que leva a sistemas de produção distintos. As maiores empresas do setor têm mecanismos de monitoramento de custos, mas encontram dificuldades para determinar o custo econômico da produção de leite. Este é um problema realçado por produtores e pesquisadores.

Em geral, o processo produtivo dá origem a dois produtos: leite e bezerras. A forma mais usual para aferição de custos tem sido a metodologia de Custo Total da Atividade Leiteira, que inclui tanto as atividades de produção de leite quanto a criação de fêmeas para reposição do rebanho de vacas. Nesse enfoque, o Custo Total do Leite é estimado, adotando-se o artifício de se deduzir do Custo Total da Atividade Leiteira, o valor equivalente ao percentual de participação da renda proveniente da venda de animais na renda bruta da atividade leiteira. Este procedimento, contudo, não guarda fidelidade à teoria de econômica de custos.

Os diferentes estrangulamentos relatados interferem de modo diferenciado na competitividade e na eficiência em cada um dos corredores. Essa interferência é, contudo, pouco conhecida. As empresas de laticínios dominam informações dos corredores que atuam. Mas nenhuma está presente em todos os principais corredores, o que não permite comparações. Por outro lado, trabalhos realizados pela academia e por órgãos do governo têm focado tópicos específicos de estrangulamentos e limitados ao âmbito regional. Há ainda o fato de levantamentos de custos serem realizados por meio de diferentes procedimentos metodológicos. Esse conjunto traduz na impossibilidade, até o presente, de se proceder análises que levem a 
conclusões seguras e análises comparativas sobre a competitividade e a eficiência do SAG do leite nacional.

\subsection{Objetivos}

O objetivo geral deste trabalho é analisar diferenças de competitividade e eficiência entre os principais corredores do SAG do leite no Brasil.

Especificamente, pretende-se:

1. Diagnosticar diferenças na regulamentação do leite nos principais países e suas consequências sobre 0 mercado internacional, notadamente sobre países importadores como o Brasil, e possíveis adaptações de políticas de intervenção, frente ao Acordo Agrícola da Organização Mundial do Comércio OMC;

2. Aferir o custo econômico e estimar o resultado exclusivamente da produção do leite em propriedades amostradas e em cadeias produtivas de corredores selecionados;

3. Analisar diferenças de competitividade e eficiência entre os principais corredores do SAG do leite no Brasil.

\subsection{Hipóteses}

As hipóteses principais desta pesquisa são: i) as propriedades leiteiras e as cadeias produtivas escolhidas são majoritariamente competitivas e eficientes; ii) o desempenho econômico, contudo, é comprometido por políticas públicas e falhas de mercado, tanto internacionais quanto domésticas, e iii) tudo isso tem impacto diferenciado em cada um dos corredores. 


\subsection{Organização do trabalho}

Este trabalho compõe-se de seis capitulos, incluindo esta introdução. No segundo capítulo é analisada a importância do SAG do Leite no contexto da economia brasileira e as características estruturais apresentadas, em termos de produção, processamento, transporte e distribuição/consumo de leite no Brasil.

O terceiro capítulo aborda os desenhos regulatórios domésticos voltados ao leite, em diferentes regiões mundiais. Procurou-se, dessa forma, caracterizar as distorções geradas por essas políticas domésticas de intervenção, que impactam e restringem as transações lácteas internacionais e interferem na competitividade e na eficiência do SAG lácteo mundial, com reflexos especialmente no caso de países historicamente importadores, como é o caso do Brasil.

O capitulo quatro discute as caracteristicas produtivas das propriedades amostradas e que formam os diferentes corredores. Apresenta também a opinião de produtores quanto a aspectos relevantes que interferem no desempenho econômico das propriedades e na competitividade dos corredores, tais como suas posições quanto à relação com os laticínios e a visão que têm de instituições relacionadas ao seu negócio.

O quinto capítulo traz os resultados obtidos quanto à eficiência e à competitividade das propriedades e das cadeias produtivas do Leite Longa Vida e Leite em Pó, em cada um dos corredores. No capítulo seis são reunidas as conclusões obtidas nesse trabalho. 


\section{SAG DO LEITE NO BRASIL: UMA REVISÃO E ANÁLISE CRÍTICA}

Este capítulo tem como propósito situar o SAG do Leite nacional, focando suas caracterísiticas recentes, motivadas pela desregulamentação ocorrida, em contraponto ao período de regulamentação plena. A seção 2.1 apresenta revisão bibliográfica a respeito destes dois periodos.

A seção 2.2 foi construída no sentido de demonstrar que o leite tem relevante inserção na economia brasileira, como gerador de empregos, de renda e de tributos, destacando-se em comparação com setores tradicionalmente lembrados por apresentarem estas características.

A seção 2.3 discute as transformações ocorridas na década noventa, após a desregulamentação do SAG, seguindo uma tendência verificada em toda a economia. Essa discussão considerou os efeitos ocorridos na produção, no transporte, no processamento e na distribuição/varejo. Também foram apresentadas as condições estruturais do consumo de lácteos no mercado nacional.

Na seção 2.4 a analise é complementada, ressaltando-se os pontos principais elencados ao longo do capítulo.

\subsection{Evolução do setor de leite e laticínios}

\subsubsection{Período da regulamentação}

Os estudos econômicos referentes à atividade leiteira no Brasil ocorreram com maior frequência a partir da década dos sessenta e analisaram 
mais intensamente Minas Gerais e São Paulo, os dois principais estados em produção de leite. O foco se deu em sistemas de produção então vigentes. Objetivavam detectar pontos de estrangulamento e ineficiências, num período de tabelamento de preços, onde o setor primário era a base para essa política. Os estudos subsidiaram estruturas de pesquisa e de difusão de tecnologia voltadas para o produto, então recem-criadas.

Como exemplo, podem ser citados os trabalhos de Araújo (1981), Barroso (1961), Casali (1981), Engler (1961), Magalhães (1971), Martins (1987), Moricochi (1973), Noronha (1974), Peres (1969) Teixeira Filho (1964), Tollini (1964) e Veiga (1978). Estes autores identificaram inadequada infraestrutura nas propriedades, práticas sanitárias e condições de higiene insatisfatórias, utilização irracional de fatores de produção e baixo potencial genético do rebanho. Os estudos desta época, em geral, configuraram um cenário de baixo nível tecnológico na atividade primária, com reflexos diretos e desfavoráveis na qualidade, na quantidade e no custo de produção.

$\mathrm{Na}$ década dos oitenta os estudos incorporaram análises referentes aos demais segmentos e os reflexos das políticas públicas sobre o SAG do leite. Farina (1983) foi o primeiro trabalho a discutir o assunto sob esse foco e concluiu pela nefasta intervenção do governo, responsável pelo pouco dinamismo produtivo então existente. Homem de Melo (1985) verificou que, entre 1977 e 1984, os preços reais recebidos pelos produtores de leite tinham reduzido anualmente, chegando em 1984 a $66 \%$ do que eram em 1977 . Em outra contribuição, Homem de Melo (1988) concluiu que seria necessário o crescimento da produção de leite entre $5,6 \%$ e $8,4 \%$ ao ano até 1995 e entre $3,8 \%$ e $5,9 \%$ ao ano, entre 1996 e 2000 , para satisfazer as necessidades do mercado interno.

Trabalhos como os mencionados e a crise de escassez de alimentos que se instalou nos meses que sucederam à implantação do Plano Cruzado, 
levaram o Governo a estabelecer parâmetros para reajustes do preço recebido pelo produtor de leite, visando estimular investimentos em aumento de produção e de produtividade. Isso resultou na criação da Planilha de Custo de Produção de Leite da Embrapa, em 1987, apresentada em Gomes et al. (1989). Sua finalidade, como norteadora de reajustes de preços, nunca se consolidou.

\subsubsection{Período pós-desregulamentação}

A partir dos anos noventa, há uma ampliação da contribuição de estudos. Optou-se então por um ordenamento por assuntos.

\subsubsection{Transformações no SAG do leite nacional}

Em 1991, o Estado deixou de regulamentar preços praticados ao longo da cadeia e vários trabalhos discutiram as repercussões desse novo período. Meireles (1996) afirmou que as mudanças, ao terem se dado sem prévia preparação, encontraram os agentes não acostumados a negociar, o que justificaria a instabilidade de preços ocorrida nos primeiros anos.

A manutenção de baixa produtividade do rebanho, a reduzida produção por propriedade e a qualidade inferior do leite entregue aos laticínios foram fatores apontados por Faria (1995) e Rodrigues (1999) como restrições a serem vencidas, visando dotar a atividade láctea de competitividade frente aos produtos importados.

Dadas a facilidade de importação e a existência de prática de subsídios no mercado lácteo internacional, Farina (1995) concluiu que os produtores necessitariam de conhecimento técnico relativo ao comércio internacional e os laticínios teriam de investir em marca, face à disponibilidade de novos produtos e marcas importadas. A configuração de um mercado varejista mais competitivo fol confirmada posteriormente por Kardel (1999). 
Quanto ao segmento indústria, Barros et al. (2001), Instituto Global MacKinsey (1999) e Martins \& Yamaguchi (1998), encontraram processo de concentração industrial, com aquisições de laticínios médios por grandes empresas. De Nigri (1997) e Nascimento (1999) concluiram que este fenômeno foi provocado principalmente por empresas de capital transnacional, que aumentaram a participação no mercado brasileiro.

Após quase uma década de experiência de desregulamentação do setor, Jank \& Galan (2000) concluiram que cresceram o mercado de produtos não inspecionados e a importação de lácteos, bem como a captação das maiores empresas, ao mesmo tempo em que ocorreu a redução de número de produtores, fornecedores dessas empresas. Jank et al. (1999) propuseram um conjunto de medidas para o SAG do leite, como a revisão de normas de qualidade na produção e comercialização, a melhoria dos sistemas de inspeção sanitária, o monitoramento das importações, bem como o estímulo à especialização de produtores, dentre outras.

\subsubsection{Relação produtor - indústria}

A partir da desregulamentação do SAG do leite, estudos que abordam a relação entre o setor de produção e a indústria passaram a merecer atenção por parte de estudiosos. Mendes (1999) afirmou que melhorias na coordenação de ações entre os segmentos que compõem o SAG do leite é item básico para que este se torne mais competitivo. Galan (2000), Araújo (1999) e Dornelas (2000) concluiram que os produtores apresentam custos de transação maiores que os dos laticínios, dada a perecibilidade do leite in natura. O uso de tanques de resfriamento de leite cresce o custo de transação, pois representa elevada especificidade de ativo. Os custos de aquisição são relativamente altos e específicos à atividade leiteira. Embora isso ocorra, contraditoriamente, as distintas amostragens realizadas pelos autores demonstraram que as relações entre produtor-indústria se davam em sua 
quase totalidade por meio de contratos informais. O que se espera é que, em situações de elevada especificidade de ativos, haja relações contratuais formais, salvaguardando as partes contra ações oportunistas.

\subsubsection{Comércio internacional e o SAG do leite nacional}

O Brasil caracteriza-se como histórico importador de derivados lácteos. Após a desregulamentação, a quantidade importada cresceu significativamente. Esse fato motivou a realização de vários estudos na década dos 90 .

Ao analisar o Mercosul, Lopes \& Jank (1992) concluíram que haviam distorções causadas por políticas macroeconômicas e setoriais no Brasil, que discriminavam contra o SAG do leite nacional. Cruz et al. (1993) concluíram que o leite fluído da Argentina e do Uruguai eram competitivos no mercado nacional a uma distância de $810 \mathrm{~km}$ e $1125 \mathrm{~km}$, respectivamente. O leite em pó mostrou-se competitivo nos principais mercados nacionais.

A adoção de políticas "antidumping" foi defendida por Lopes (1995), visando dificultar a importação de leite. Nonnenberg \& Mendonça (2000), contudo, obtiveram resultados que os levaram a conclusões opostas. Para esses autores, não foi a alteração na política comercial que levou ao aumento das importações, mas a adoção do Plano Real e a desregulamentação que criaram condições favoráveis para o aumento da demanda de lácteos importados.

Por outro lado, Barros et al. (2000) afirmaram que o volume de produtos lácteos importados não causam o preço no mercado interno, mas o preço dos produtos importados causam efeito sobre o valor pago aos produtores. 


\subsection{Relevância do SAG do leite no contexto da economia brasileira}

O SAG do leite é um dos mais complexos do agronegócio brasileiro. A título de exemplo, no setor de produção primária é necessário gerar ou adquirir insumos e serviços, tais como mudas e sementes de milho, sorgo, caroço de algodão, azevém, aveia, cana-de-açúcar, farelos de soja e trigo, minerais, polpa citrica, cevada, dentre outras. A atividade de produção adquire também produtos de formulação química, como medicamentos, adubos e defensivos agrícolas, material de higiene e limpeza, além de sêmen e produtos auxiliares. Adquire ainda diferentes tipos de máquinas e implementos, bem como serviços a esses relacionados.

Por outro lado, o SAG do leite apresenta uma cadeia produtiva extensa. Após a produção, o leite é levado a um posto de resfriamento e, em seqüência, transportado para a usina de beneficiamento, de onde, após a transformação, os derivados lácteos são destinados a centrais de distribuição ou a outros setores da economia, que os utilizam como insumo.

É também importante na geração de emprego, renda e tributos. Com base nas Matrizes de Recursos e Usos para o Brasil elaboradas para o ano de 1996, pelo Instituto Brasileiro de Geografia e Estatística - IBGE, Martins \& Guilhoto (2001) concluíram que a Indústria de Laticínios apresentou potencial gerador de empregos maior que setores tradicionalmente aceitos como relevantes sob esse aspecto, como Construção Civil, Indústria Têxtil, Siderurgia e Fabricação de Automóveis, dentre outros. Este setor mostrou-se também relevante em termos de geração de renda e tributos, conforme simulação realizada pelos autores para um aumento na demanda, no valor de R\$ 1 milhão (Tabela 1). 
Tabela 1. Estimativa de geração de emprego, renda e tributos para um aumento de demanda de $\mathrm{R} \$ 1$ Milhão, em setores selecionados.

\begin{tabular}{lccc}
\hline \multicolumn{1}{c}{ Setores } & $\begin{array}{c}\text { Empregos } \\
\text { (unidade) }\end{array}$ & $\begin{array}{c}\text { Renda } \\
\text { (R\$ mil) }\end{array}$ & $\begin{array}{c}\text { Tributos } \\
\text { (R\$ mil) }\end{array}$ \\
\hline Leite e Derivados & 197 & 1.060 & 54 \\
Calçados & 191 & 1.170 & 50 \\
Peças e Outros Veículos & 129 & 1.170 & 47 \\
Construção Civil & 128 & 1.010 & 110 \\
Maquinas e Equipamentos & 122 & 1.170 & 43 \\
Indústria Têxtil & 122 & 940 & 42 \\
Material Elétrico & 122 & 1.090 & 49 \\
Siderurgia & 116 & 990 & 49 \\
Automóveis/caminhões/ônibus & 102 & 940 & 41 \\
Eletrônicos & 91 & 860 & 36 \\
\hline
\end{tabular}

Fonte: Martins \& Guilhoto (2001)

Ainda com base nesses autores, o vínculo entre a Indústria de Laticínios e o setor primário mostrou-se bastante acentuado. Das 1764 relações intersetoriais da economia, a Indústria de Laticínios tem duas entre as 50 maiores, sendo que a quinta relação com maior intensidade de toda a economia se deu entre a Indústria de Laticínios e o Setor Agropecuário. Quando se expandiu a análise para as 176 ligações intersetoriais mais intensas, a Indústria de Laticínios surgiu em 11 ligações, ficando em quinta posição, num total de 42 setores que retratam a economia brasileira.

Nos resultados apresentados na Tabela 2, verifica-se que a Indústria de Laticinios tem a característica de impulsionar de maneira significativa 0 crescimento de setores que se colocam como seus fornecedores, obtendo o quinto melhor Índice de Ligação para Trás, no contexto da economia brasileira. Este desempenho não se reproduz com a mesma intensidade, quando se considera o Índice de Ligação para Frente, o que traduz a menor vitalidade desse setor para impulsionar os setores que se colocam à jusante da cadeia produtiva. Os resultados foram obtidos pelo cálculo dos Indices de Rasmussen- 
Hirschman, que definem os setores chave da economia. Ao apresentar Índice de Ligação para Trás maior que a unidade, a Indústria de Laticínios demonstrou poder de encadeamento com outros. É, portanto, setor chave no processo de crescimento.

Tabela 2. Índices de Ligação de Rasmussen-Hirschman por Setores Selecionados, Brasil, 1996.

\begin{tabular}{lcccc}
\hline Setores & Ind. Lig. Para Trás & Posiçăo* & Ind. Lig. Para Frente & Posição* \\
\hline Indústria de Laticínios & 1,24 & 5 & 0,66 & 33 \\
Material Elétrico & 1,16 & 10 & 0,71 & 28 \\
Indústria Têxtil & 1,14 & 12 & 1,36 & 7 \\
Artigos do Vestuário & 1,13 & 14 & 0,52 & 41 \\
Fabricação Calçados & 1,12 & 16 & 0,62 & 37 \\
Autom./Cam./Ônibus & 1,11 & 17 & 0,54 & 40 \\
Máquinas e Equip. & 0,92 & 28 & 1,17 & 12 \\
Construção Civil & 0,82 & 33 & 0,65 & 35 \\
Equip. Eletrônicos & 0,85 & 31 & 0,57 & 38 \\
\hline
\end{tabular}

Fonte: Martins \& Guilhoto (2001)

* Refere-se à posição obtida pelo setor em comparação com 42 setores que compõem a economia brasileira

Portanto, os resultados demonstraram que a Indústria de Laticínios gera impactos maiores para os setores que lhe são fornecedores, embora tenha desempenho melhor, para frente, que setores relevantes como Construção civil, Fabricação de Calçados, Automóveis/Caminhões/Ônibus e Artigos do Vestuário.

Estes dados auxiliam no entendimento da importância do SAG do leite na economia brasileira e da relevância assumida pela Indústria de Laticínios dentro deste sistema. Adicionalmente, auxiliam também no entendimento do impacto que variações de demanda geram sobre este Sistema Agroindustrial. Considerando-se que no modelo de Insumo-Produto as famílias, o Governo e as transações com o resto do mundo definem a 
demanda, é possível perceber que aumento/retração na renda das famílias, nos gastos do Governo e na dificuldade/facilidade em importações lácteas podem estimular/desestimular o SAG do leite nacional.

Numa retrospectiva histórica, os instrumentos macroeconômicos que operaram a política de substituição de importações na segunda metade do século $X X$, até a década dos oitenta, impactaram o SAG do leite nacional. Por ser típico de mercado interno, a dificuldade em importar contribuiu para estagnação tecnológica, ao inibir a concorrência.

Por outro lado, países de industrialização tardia, como o Brasil, adotaram política de "alimento barato" como mecanismo de alavancagem do setor urbano-industrial (De Janvri, 1978). No caso dos lácteos brasileiros, isso se acentuou no período recessivo dos anos oitenta. Como leite e derivados apresentam elevado peso no cálculo do índice de Preços ao Consumidor, a política de tabelamento de preços contribuiu no combate à inflação (Martins, 1986). Com efeito, o controle de preços inibiu a demanda por investimentos em tecnologia de produtores comerciais. Ademais, a recessão econômica daquela década não estimulou um crescimento significativo da demanda de lácteos. No segmento industrial, reproduziu-se o que ocorria nos demais setores da economia: a incorporação de vários laticínios de administração familiar por grupos maiores, notadamente multinacionais (Farina,1997; De Nigri, 1997).

$\mathrm{Na}$ década dos noventa, entretanto, tiveram início substanciais transformações no setor. Após 1991, o Estado deixou de estabelecer preços de comercialização, rompendo com uma tradição que vinha desde 1945. Com a abertura econômica e a implantação do Plano Real, a produção em 1999 foi 4,7 bilhões de litros superior a obtida em 1990, enquanto em 1989 a produção de leite foi superior em 2,6 bilhões de litros à produção de 1980 (Embrapa Gado de Leite, 2001). 
A livre negociação de preços, contudo, gerou inicialmente um quadro de turbulência, motivado por interesses diferenciados entre produtores e indústria. Passados estes momentos, o que se verificou foi um esforço no sentido de se reduzir custos e ineficiências, bem como melhorar a qualidade $\mathrm{e}$ diversificar os derivados ofertados. A busca de eficiência ultrapassou o nível da fazenda e chegou até ao varejo, com investimentos realizados em todos os segmentos. Este fenômeno recente inseriu o setor na lógica de organização industrial por meio de cadeia produtiva, conceito que foi relevante para a redução de custos nos Estados Unidos, Europa e Argentina.

Quanto aos grupos de interesse, o controle de preços ensejou a existência de lideranças com discursos em defesa de reajustes de preços pagos ao produtor. As assembléias de sindicatos e de cooperativas somente se mostravam participativas quando esta bandeira era empunhada. Com o término do controle de preços, essas lideranças perderam sua principal bandeira aglutinatória. A partir da segunda metade da década dos 90 , surgiu um novo estilo de representação dos interesses lácteos. Associações de produtores passaram a contar com corpo técnico, a acompanhar e propor alternativas para os produtores. Além disso, contrataram consultorias e estudos técnicos de universidades, visando dar sustentação às argumentações em prol de seus interesses. A resultante foi o soerguimento reivindicatório, que passou a discutir questões relativas a importações, definição de políticas de financiamento, bem como a adoção de novas legislações vinculadas aos lácteos. O Movimento S.O.S. Leite, que envolveu o Congresso Nacional em 1997, é o "divisor de águas" deste processo, que culminou com adoção de medidas "antidumping", adotadas pelo governo. (Martins \& Araújo, 2000; Martins \& Gomes, 2000). 


\subsection{Transformações no SAG do leite após a desregulamentação}

\subsubsection{Segmento produção}

Este segmento apresentou importantes transformações, após o período de desregulamentação. A primeira diz respeito ao aumento da produção nacional em $36 \%$ na década (Tabela 3 ). A segunda refere-se à mudança do mapa de produção. As regiões Centro-Oeste e Sul cresceram a produção respectivamente em $81 \%$ e $50 \%$, enquanto que a região Sudeste, cresceu a produção em $24 \%$.

Tabela 3. Produção de leite e distribuição percentual por regiões, Brasil, 19902000 (milhões de litros).

\begin{tabular}{lcrcrcr}
\hline \multirow{2}{*}{ Região } & \multicolumn{2}{c}{1980} & \multicolumn{2}{c}{1990} & \multicolumn{2}{c}{2000} \\
\cline { 2 - 7 } & Produção & \multicolumn{1}{c}{$\%$} & Produção & \multicolumn{1}{c}{$\%$} & Produção & $\%$ \\
\hline Sudeste & 5.669 & 50,8 & 6.923 & 47,9 & 8.573 & 43,4 \\
Sul & 2.572 & 23,0 & 3.262 & 22,5 & 4.904 & 24,8 \\
Nordeste & 1.569 & 14,1 & 2.045 & 14,1 & 2.160 & 10,9 \\
Centro-Oeste & 1.208 & 10,8 & 1.698 & 11,7 & 3.080 & 15,6 \\
Norte & 145 & 1,3 & 555 & 3,8 & 1.050 & 5,3 \\
Brasil & 11.163 & 100,0 & 14.493 & 100,0 & 19.767 & 100,0 \\
\hline
\end{tabular}

Fonte: Banco de dados econômicos da Embrapa Gado de Leite (2001)

A produção está migrando de estados tradicionais em leite, para o Centro-Oeste, estados do Norte e Bahia, que apresentam menor custo de produção, conforme constatou Reis et al. (1998). Os cinco principais estados produtores foram os mesmos durante toda a década, conjuntamente respondendo por pouco mais de dois terços da produção nacional (Tabela 4). Os estados de Minas Gerais e São Paulo, entretanto, tiveram variação de produção, entre 1990 e 2000 , de $37 \%$ e $-5 \%$, respectivamente, enquanto que o 
crescimento conjunto dos cinco estados foi de $39 \%$, em igual período. A produção do estado Rio Grande do Sul cresceu $45 \%$, enquanto que os estados do Paraná e de Goiás se destacaram, com crescimento de 55\% e 100\%, respectivamente.

Tabela 4. Os cinco estados da Federação maiores produtores de leite, Brasil, 1990-2000 (bilhões de litros).

\begin{tabular}{cccccccc}
\hline Ano & MG & SP & RS & PR & GO & TOTAL & $(\%)^{*}$ \\
\hline 1990 & 4,29 & 1,96 & 1,45 & 1,16 & 1,07 & 9,94 & 68,7 \\
1991 & 4,32 & 1,98 & 1,49 & 1,24 & 1,17 & 10,19 & 67,6 \\
1992 & 4,50 & 2,02 & 1,60 & 1,28 & 1,28 & 10,68 & 67,7 \\
1993 & 4,53 & 2,05 & 1,59 & 1,36 & 1,41 & 10,93 & 70,0 \\
1994 & 4,58 & 2,01 & 1,63 & 1,42 & 1,41 & 11,04 & 70,0 \\
1995 & 4,76 & 1,98 & 1,71 & 1,58 & 1,45 & 11,48 & 69,7 \\
1996 & 5,50 & 1,85 & 1,89 & 1,36 & 1,83 & 12,42 & 69,3 \\
1997 & 5,60 & 2,00 & 1,91 & 1,58 & 1,87 & 12,47 & 66,8 \\
1998 & 5,70 & 2,20 & 2,04 & 1,80 & 1,91 & 13,65 & 69,8 \\
1999 & 5,81 & 2,32 & 2,14 & 2,03 & 1,95 & 14,24 & 69,9 \\
2000 & 5,87 & 1,86 & 2,10 & 1,80 & 2,19 & 13,82 & 69,9 \\
\hline
\end{tabular}

Fonte: Banco de dados econômicos da Embrapa Gado de Leite

* Refere-se ao percentual de participação de produção dos cinco estados na produção nacional

Numa comparação entre três décadas, conforme apresentado na Tabela 5, percebe-se que a taxa anual de crescimento da produção na década dos noventa foi maior que na década imediatamente anterior. O número de vacas ordenhadas decresceu anualmente, caracterizando aumento de produtividade, marca do período pós-desregulamentação. 
Tabela 5. Estimativa de Taxa Anual de Crescimento - T.A.C. da produção, vacas ordenhadas e produtividade, por décadas, Brasil, 1970-1999 (\% ao ano).

\begin{tabular}{lccc}
\hline & $1970-79$ & $1980-89$ & $1990-99$ \\
\hline Produção & 4,84 & 2,60 & 3,31 \\
Vacas Ordenhadas & 6,34 & 1,43 & $-2,03$ \\
Produtividade * & $-1,40$ & 1,16 & 5,45 \\
\hline
\end{tabular}

Fonte: Yamaguchi et al. (2001)

* Variável expressa em produção por vaca ordenhada

A produção cresceu enquanto decresceu o preço recebido pelos produtores em $-7,5 \%$ ao ano, média para o Brasil (Yamaguchi et al., 2001). A Figura 1 demonstra que os preços mensais têm tendência de queda desde 1987, nos cinco maiores estados produtores. Essa tendência antecede o período da desregulamentação, a partir de 1991. Por outro lado, na medida em que se consolidou o novo cenário de negociação entre produtores e indústria, a diferença entre os preços recebidos pelos produtores nos cinco estados tendeu a ser cada vez menor.

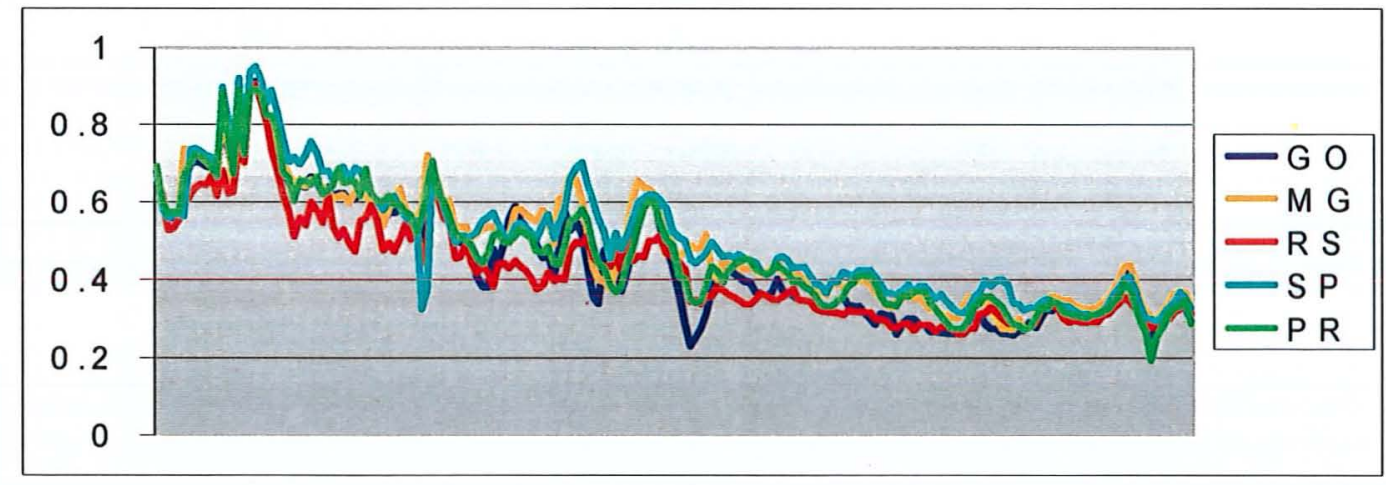

Figura 1 - Preços reais mensais recebidos por produtores de leite em cinco estados, Brasil, Janeiro de 1986 a Agosto de 2001.

Fonte: Banco de Dados USP,ESALQ,CEPEA Nota: Preços deflacionados por IGP-DI da FGV/RJ 
Embora aparentemente contraditório ter-se elevação da produção concomitante com queda de preços recebidos, isso pode ser explicado pelo aumento da produtividade apresentada na Tabela 5 . É possível que esteja ocorrendo no setor de produção de leite nacional o fenômeno caracterizado por Cochrane (1958) como Technological Treadmill ou seja, os produtores inovadores adotam novos procedimentos tecnológicos e temporariamente obtêm ganhos extras. Na medida em que estes procedimentos se universalizam a oferta do produto se eleva, o que induz a uma queda de preços recebidos pelos produtores. Os últimos a adotarem as inovações ou aqueles que não as adotam tendem a apresentar dificuldades de sobrevivência na atividade.

No caso do leite, ao longo da década passada foi introduzida e consagrada a prática de pagamento de preços diferenciados entre os produtores de leite, inclusive nas cooperativas, com decisão favorável do Conselho Administrativo de Defesa Econômica - CADE, em julgamento ocorrido em 1999. Alguns critérios são utilizados na definição da diferenciação de preços. Um deles diz respeito ao leite resfriado. Nos primeiros anos, como havia resistência dos produtores em adquirir o tanque de resfriamento e construir as instalações necessárias, as empresas financiaram estas operações, amortizando em até 48 meses com 12 de carência e assumindo os custos de transação. Os produtores passavam a ter ganhos imediatos, na medida em que reduzia o custo de transporte, aumentava o preço recebido por litro e ainda podiam introduzir a segunda ordenha, aumentando a produção.

Outros procedimentos indutores de adoção de tecnologia, como o descrito, foram também disseminados, levando ao aumento de produtividade. Além disso, três outros fatores auxiliam no entendimento do fenômeno do aumento da produtividade. O primeiro diz respeito a um importante trabalho de conscientização quanto à necessidade do produtor atuar de maneira profissionalizada na atividade, desenvolvido por técnicos dos laticínios e por 
professores/pesquisadores de universidades e agências do governo, além de um marcante envolvimento das federações estaduais e da Confederação Nacional da Agricultura - CNA.

O segundo está relacionado à queda do preço real da ração ao longo da década dos noventa, que segundo Yamaguchi et al. (2001) apresentou taxa negativa de crescimento de preços $(-6,1 \%$ ao ano), próximo da taxa anual de $-7,5 \%$ para o preço recebido pelos produtores em igual período.

Um terceiro fator explicativo, de difícil verificação empírica e de apelo dedutível, diz respeito à queda das taxas de inflação. Em geral, o produtor recebe o valor da produção mensalmente do laticínio, no mês subseqüente à entrega. Se o pagamento se dá, por exemplo, sempre no dia 3 de cada mês, são decorridos entre 33 e 3 dias entre a produção entregue no primeiro e último dia do mês anterior e o efetivo pagamento. Portanto, em média, o produtor será remunerado 18 dias após a produção. Num periodo de inflação elevada, há uma corrosão do valor real recebido pelo produtor. O mecanismo inflacionário reduz, assim, o poder de compra do produtor de leite, dado pela renda líquida auferida na atividade. Se ocorrer controle da inflação e esta se estabilizar próxima de zero, haverá um ganho real de renda para o produtor que, estimulado, tenderá a responder com aumento da produção.

Dessa forma, o aumento de produtividade ocorrida nos anos 90 poderia ser explicado parcialmente pela redução do preço da ração importante ítem de custo - pela decisiva ação de laticínios, de lideranças de produtores e de universidades e agências de pesquisa e difusão, além de sensivel redução do imposto inflacionário. 


\subsubsection{Segmento transporte até a usina de processamento}

Até a primeira metade dos anos noventa, o transporte do leite das propriedades até as usinas de beneficiamento se dava por meio de caminhões comuns, acondicionados em latões. Em pontos de coleta à beira da estrada, permaneciam expostos à temperatura ambiente. A coleta era feita diariamente e o custo dessa operação correspondia entre $4 \%$ e $25 \%$ do preço do leite recebido pelo produtor (Ferreira Sobrinho et. al., 1995). Vale registrar que o frete até à usina tradicionalmente é arcado pelo produtor.

A partir da segunda metade da década dos noventa foi introduzida e rapidamente disseminada a coleta a granel, com transporte em caminhões isotérmicos. Após a ordenha, o leite é imediatamente resfriado em tanques apropriados, permanecendo nesta condição até a chegada do caminhão, a cada dois dias. Assim, há redução do custo de transporte e melhoria da qualidade da matéria-prima. Botelho (1997) e Silva (1999) encontraram redução de 28 a $39 \%$ no custo do frete em relação ao transporte por latão.

No contexto da adoção da coleta de leite a granel, os laticínios introduziram o conceito de logística integrada, o que levou ao fechamento de postos de resfriamento, redução de rotas de coleta, demissão de pessoal e aumento de carga transportada por caminhão.

\subsubsection{Segmento indústria}

A tendência de concentração de mercado está presente desde os anos setenta e acentuou-se na década dos noventa. Tem ocorrido incorporações e associação de empresas, em geral de nacionais com transnacionais, ao mesmo tempo em que novas plantas industriais estão sendo implementadas, principalmente na região Centro-Oeste. Em 1998, a Parmalat adquiriu $51 \%$ do controle da marca Batavo para produtos lácteos. A Itambé 
está à procura de uma associação estratégica, enquanto a Cooperativa Paulista vendeu sua marca.

Além da busca de poder de mercado, o objetivo de melhorar o desempenho tem levado os principais laticínios a reduzir o número de fornecedores de matéria-prima, sem que haja redução do volume captado, conforme demonstram as estatísticas das Tabelas 06 e 07 . Dos doze maiores laticínios, todos estão implantando esta política.

Tabela 6. Número de unidades fornecedoras dos doze principais laticínios, Brasil, 1996-2000 (em mil unidades).

\begin{tabular}{clrrc}
\hline Ordem (1) & Empresa & \multicolumn{1}{c}{1996} & \multicolumn{1}{c}{2000} & 2000/1996(\%) \\
\hline 1 & Nestlé & 39,2 & 14,1 & 35,7 \\
2 & Parmalat & 35,8 & 15,6 & 43,6 \\
3 & Itambé & 19,9 & 8,4 & 42,2 \\
4 & Elege & 44,0 & 32,2 & 73,2 \\
5 & CCL/SP (2) & 25,4 & 8,9 & 35,0 \\
6 & Batavia & 11,8 & 7,5 & 63,6 \\
7 & Grupo Vigor & 8,4 & 3,7 & 44,0 \\
8 & Leite Lider & n.d. & 8,8 & n.d. \\
9 & Centroleite (2) & n.d. & 4,2 & n.d. \\
10 & Morrinhos & n.d. & 7,3 & n.d. \\
11 & F.Royal (Glória) & 6,0 & 2,3 & 38,3 \\
12 & Danone & 2,1 & 1,4 & 66,7 \\
\hline
\end{tabular}

Fonte: Banco de dados econômicos da Embrapa Gado de Leite

(1) Ordem com base na quantidade leite recebida em 2001; (2) CL/SP = Cooperativa Central de Laticínios do Estado de São Paulo; Centroleite = Cooperativa Central de Laticínios de Goiás 
Tabela 7. Volume diário de leite recebido por produtor em doze dos principais laticínios, Brasil, 1996-2000 (em litros).

\begin{tabular}{clrrc}
\hline Ordem (1) & Empresa & 1996 & 2000 & $2000 / 1996(\%)$ \\
\hline 1 & Nestlé & 100 & 270 & 170,0 \\
2 & Parmalat & 61 & 162 & 165,6 \\
3 & Itambé & 98 & 252 & 157,1 \\
4 & Elege & 35 & 65 & 85,7 \\
5 & CCL/SP (2) & 72 & 157 & 118,1 \\
6 & Batavia & 62 & 100 & 61,3 \\
7 & Grupo Vigor & 99 & 170 & 71,7 \\
8 & Leite Lider & n.d. & 64 & n.d. \\
9 & Centroleite (2) & n.d. & 114 & n.d. \\
10 & Morrinhos & n.d. & 55 & n.d. \\
11 & F.Royal (Glória) & 80 & 164 & 105,0 \\
12 & Danone & 225 & 251 & 11,6 \\
\hline
\end{tabular}

Fonte: Banco de dados econômicos da Embrapa Gado de Leite

(1) Ordem com base na quantidade leite recebida em 2001; (2) CCL/SP = Cooperativa Central de Laticínios do Estado de São Paulo; Centroleite = Cooperativa Central de Laticínios de Goiás

A Indústria de Laticínios é a principal responsável pela implementação das transformações em curso nos diferentes segmentos da cadeia produtiva. Fomentou a aquisição de tanques de resfriamento pelos produtores, por meio de intermediação financeira. Induziu também a adoção de tecnologia intensiva em pastagem e na melhoria administrativa das unidades produtivas, por exemplo. Plantas industriais de maior escala e tecnologia de processamento mais eficiente e que levem à diferenciação de produtos têm sido incorporadas, visando a manutenção e conquista de mercado.

O novo perfil da indústria tem motivado mudanças na cultura das empresas, no sentido de se manterem atualizadas frente a tendências mundiais do setor. Para Castro \& Neves (2001), os segmentos que apresentam maior índice de automação são os que têm demandado larga escala produtiva 
e número reduzido de produtos na linha de produção, como o leite ultra high temperature - UHT, conhecido como Longa Vida, e o Leite em Pó. Nesses casos, os postos de trabalho gerados são menos numerosos e com exigência de maior qualificação. São também esses os produtos em maior volume importados pelo Brasil e, portanto, estão submetidos mais intensamente à competição. Por outro lado, as empresas têm promovido profundas reformas administrativas, objetivando a simplificação de estruturas hierárquicas para maior agilidade na tomada de decisões. Para Castro \& Neves (2001), num contexto de poucas barreiras tecnológicas, a capacidade gerencial e a flexibilidade organizacional tornam-se os aspectos mais importantes de competitividade. Para esses autores, embora intenso, o investimento tecnológico tem sido freado por instabilidades do mercado e de políticas públicas, além da concorrência em grande escala com produtos não inspecionados que, de acordo com Jank \& Galan (2000), respondem por $40 \%$ de toda a produção nacional.

A instabilidade do mercado dificulta a plena coordenação da cadeia produtiva por parte da indústria. A manutenção de sólidos vínculos com outros setores da economia e, principalmente, com o agropecuário tem possibilitado estabelecer padrões de matéria-prima, insumos e equipamentos, ou seja, à montante da cadeia produtiva. Dois pontos, contudo, inibem o pleno exercício de coordenação. O primeiro diz respeito a sua relação com os supermercados, item a ser abordado na seção seguinte. O segundo refere-se ao fato da demanda de lácteos ser influenciada solidamente pelo poder aquisitivo do consumidor - que tem se mostrado instável ao longo dos anos - e pela facilidade/dificuldade de se importar leite.

O mercado de leite nacional conta com dois agentes importantes, que levam em consideração variáveis diferentes na decisão de comportamento. O consumidor é quem desencadeia o processo. A decisão de consumo lácteo relaciona-se positivamente com o poder de compra e inversamente ao preço 
relativo dos derivados lácteos, frente aos demais produtos. Assim, se há redução da sua renda real, motivada por inflação, ou se há perspectiva de desaquecimento da economia e uma provável onda de desemprego, ou ainda, se o preço do leite e de derivados está relativamente mais elevado que outros bens e serviços disponíveis, a tendência é de retração do consumo.

Já a indústria irá considerar a perspectiva de comportamento da demanda, se a mesma apresenta tendência de aumento ou retração, e também a facilidade de obtenção de produtos importados, para estabelecer os preços que irá praticar. Nesse caso, a análise leva em conta os preços internos e os internacionais, estes influenciados fortemente pela cotação do dólar americano frente à moeda nacional. $\mathrm{O}$ comportamento dos preços internos mensalmente recebidos ao produtor evidencia uma forte instabilidade de preços defrontada pela indústria (Figura 2)

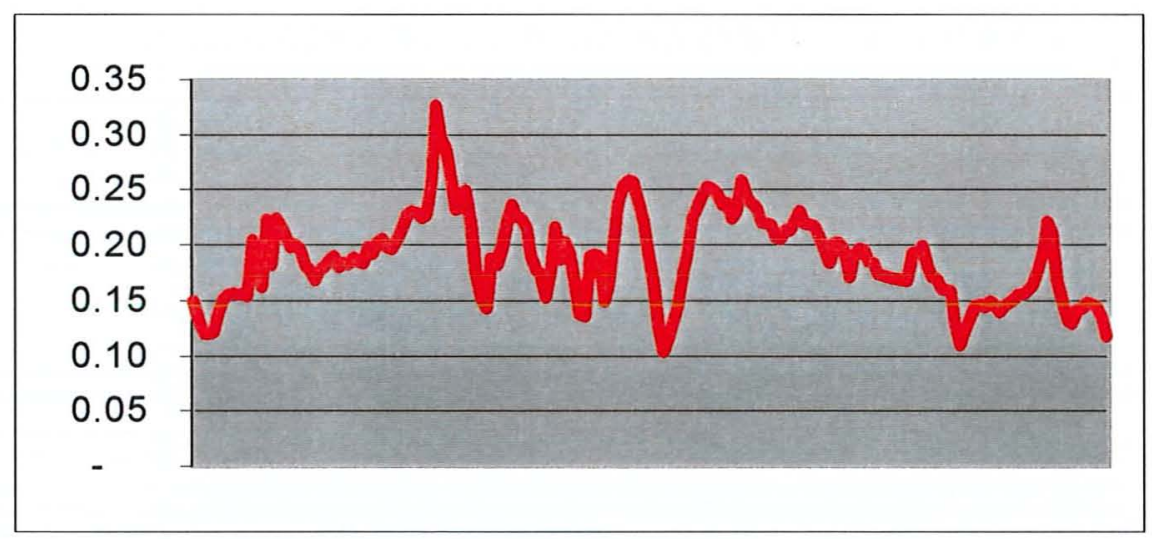

Figura 2 - Preços recebidos por produtores de leite, média dos cinco estados maiores produtores, expressos em dólar americano, Brasil, Janeiro de 1986 a Agosto de 2001.

Fonte: Banco de dados USP,ESALQ,CEPEA 


\subsubsection{Segmento distribuição/varejo}

O Plano Real, a abertura econômica e a consolidação do Mercosul trouxeram modificações quantitativas e qualitativas neste elo da cadeia/Mesmo com o expressivo crescimento da produção nacional, o país acentuou sua condição de importador líquido de leite.

Existem quatro momentos em que os percentuais de importação em relação à produção foram mạis elevados: 1973, 1986, 1991 e a partir de 1995. Em 1973 ocorreu uma elevação generalizada de preços de alimentos no Brasil, leite incluído, levando o governo a aumentar a quantidade importada para compensar a pressão de demanda. Os outros três momentos ocorreram quando foram adotados planos de controle da inflação: Plano Cruzado, Plano Collor e Plano Real.

O Plano Cruzado, implementado em 1986, marcou um importante momento para a atividade de produção de leite. Ainda que de maneira momentânea e de modo artificial, o controle das taxas inflacionárias deu à população de baixa renda um ganho real temporário em seu poder aquisitivo, o que levou a um aumento na demanda de lácteos. Como naturalmente não foi possivel aumentar instantaneamente a oferta, a alternativa do governo foi adquirir no mercado internacional a quantidade necessária para fazer frente à crise de abastecimento.

Um outro momento de crescimento significativo das importações deu-se em 1991, com a adoção do Plano Collor, que também reduziu as taxas inflacionárias temporariamente (Tabela 8). Este ano também correspondeu ao início do período de desregulamentação, com o fim do tabelamento de preços para o leite. 
Tabela 8. Produção e importação de derivados lácteos anuais em equivalente leite, Brasil, 1970-1999.

\begin{tabular}{|c|c|c|c|}
\hline Ano & $\begin{array}{c}\text { Produção(a) } \\
\text { (bilhões de litros) }\end{array}$ & $\begin{array}{c}\text { Importação(b) } \\
\text { (bilhões de litros) }\end{array}$ & $\begin{array}{c}\text { (b)/(a) } \\
(\%)\end{array}$ \\
\hline 1970 & 7,13 & 0,22 & 3,08 \\
\hline 1971 & 7,11 & 0,15 & 2,09 \\
\hline 1972 & 7,14 & 0,12 & 1,66 \\
\hline 1073 & 6,33 & 0,54 & 8,52 \\
\hline 1974 & 7,10 & 0,22 & 3,16 \\
\hline 1975 & 7,95 & 0,14 & 1,78 \\
\hline 1976 & 8,26 & 0,20 & 2,48 \\
\hline 1977 & 9,57 & 0,46 & 4,85 \\
\hline 1978 & 9,78 & 0,12 & 1,20 \\
\hline 1979 & 10,19 & 0,76 & 0,74 \\
\hline 1980 & 11,16 & 0,61 & 5,48 \\
\hline 1981 & 11,32 & 0,80 & 0,71 \\
\hline 1982 & 11,46 & 0,68 & 0,59 \\
\hline 1983 & 11,46 & 0,19 & 1,63 \\
\hline 1984 & 11,93 & 0,30 & 2,49 \\
\hline 1985 & 12,08 & 0,33 & 2,69 \\
\hline 1986 & 12,49 & 2,12 & 16,99 \\
\hline 1987 & 13,00 & 1,01 & 7,77 \\
\hline 1988 & 13,52 & 0,05 & 0,35 \\
\hline 1989 & 14,09 & 1,05 & 7,46 \\
\hline 1990 & 14,48 & 0,58 & 4,02 \\
\hline 1991 & 15,08 & 1,31 & 8,71 \\
\hline 1992 & 15,78 & 0,28 & 1,75 \\
\hline 1993 & 15,59 & 0,63 & 4,05 \\
\hline 1994 & 15,78 & 1,25 & 7,92 \\
\hline 1995 & 16,47 & 3,20 & 19,42 \\
\hline 1996 & 18,52 & 2,45 & 13,23 \\
\hline 1997 & 18,67 & 1,93 & 10,34 \\
\hline 1998 & 18,69 & 2,27 & 12,14 \\
\hline 1999 & 19,07 & 2,41 & 12,64 \\
\hline
\end{tabular}

Fonte: Banco de dados econômicos da Embrapa Gado de Leite

Naquele ano, as importações brasileiras de derivados equivaleram a 2,1 bilhões de litros de leite, ou $94 \%$ de toda a importação verificada na década anterior. Este fato torna-se ainda mais relevante ao se considerar que havia um razoável esforço no sentido de se importar ao mínimo, face à escassez de 
divisas em toda aquela década. Além disso, é relevante registrar que as importações concentraram-se basicamente no segundo semestre do ano, pois os primeiros meses de adoção do Plano mostraram-se muito instáveis, pela sua própria originalidade e a consequente dificuldade de compreensão inicial pelos agentes econômicos.

Um último momento da série histórica refere-se à adoção do Plano Real. Embora presente nos últimos trinta anos no mercado nacional, a participação do produto importado cresceu significativamente a partir de 1994. Entre 1970 e 1993 o país importou 10,6 bilhões de litros de leite, sendo que 3,4 bilhões de litros nos anos de 1986 e 1991, enquanto entre 1994 e 1999 a importação foi de 13, 5 bilhões de litros.

Os dados demonstram, portanto, que um relevante impulsionador das importações no Brasil é o comportamento do poder aquisito da população brasileira. Em momentos em que se promoveu a significativa redução das taxas de inflação, a demanda de lácteos se elevou, induzindo a um aumento nas importações, mesmo com o aumento de produção. Isso se acentua na presença de câmbio valorizado. O mecanismo estimulador de produção e consumo parece ser o mesmo: taxas inflacionárias reduzidas. Isso eleva a renda de produtores e consumidores de leite, estimulando o aumento de produção, de consumo e de importação, para o equilíbrio de mercado.

Uma segunda transformação ocorrida refere-se à mudança do tipo de leite fluido consumido. O leite tipo $\mathrm{C}$, comercializado no varejo em sacos plásticos, teve o consumo anual em queda, sendo substituído na preferência do consumidor pelo leite Longa Vida (Tabela 9). Meireles \& Alves (2001) afirmaram que a mudança de hábito do consumidor de leite fluido contribuiu para que os estados exportadores líquidos viabilizassem a colocação no mercado, de seu crescente excedente na década dos noventa nos estados importadores líquidos. Os estados exportadores de maior expressão são Minas 
Gerais, Goiás, Rio Grande do Sul, Paraná, Santa Catarina, Mato Grosso e Rondônia, enquanto São Paulo e Rio de Janeiro são os maiores importadores.

Tabela 9. Consumo de leite fluido, Brasil, 1990-99 (milhões litros).

\begin{tabular}{cccccc}
\hline Ano & Longa Vida & \multicolumn{3}{c}{ Pasteurizado } & Total \\
& & Tipo A & Tipo B & Tipo C & \\
\hline 1991 & 187 & 28 & 347 & 3.764 & 4.326 \\
1992 & 204 & 34 & 445 & 3.489 & 4.172 \\
1993 & 355 & 36 & 358 & 2.807 & 3.556 \\
1994 & 730 & 48 & 433 & 2.885 & 4.096 \\
1995 & 1.050 & 48 & 388 & 3.150 & 4.636 \\
1996 & 1.385 & 55 & 460 & 3.150 & 5.169 \\
1997 & 1.885 & 44 & 405 & 2.835 & 5.169 \\
1998 & 2.810 & 40 & 360 & 2.270 & 5.480 \\
1999 & 3.145 & 45 & 400 & 1.980 & 5.570 \\
2000 & 3.530 & 50 & 450 & 1.700 & 5.730 \\
\hline
\end{tabular}

Fonte: Banco de dados econômicos da Embrapa Gado de Leite

Uma terceira transformação diz respeito à mudança do canal de comercialização. Até o início do Plano Real, as padarias ocupavam ponto central nas vendas de varejo. Os laticínios cediam o resfriador, faziam entregas diárias e arcavam com os custos dos sacos de leite que furavam ou não eram vendidos.

O crescimento do consumo do leite Longa Vida, contudo, estimulou os supermercados a substituirem as padarias como o principal canal de distribuição no varejo. Se por um lado isso reduz os custos de distribuição, por outro coloca os laticinistas em situação de terem de negociar com um agente com maior poder de barganha. Como a tendência é de os supermercados aumentarem sua importância no varejo brasileiro, e dada a sua lógica de 
aquisição em grandes volumes, é provável que cada vez mais os laticínios de pequeno e médio portes tenham dificuldades na colocação de seus produtos, o que pode caracterizar-se numa barreira de mercado.

O faturamento das 12 principais empresas do setor de laticínios e de supermercados, em ambos os casos, não somente com leite, foi retratado por Meireles \& Alves (2001). Enquanto as 12 principais empresas de laticínios apresentaram faturamento acumulado de US $\$ 6,1$ bilhões em 2000 , somente as duas principais redes de supermercado obtiveram faturamento de US\$ 9,2 bilhões. Por outro lado, as doze maiores empresas de laticínios compradoras de leite (Tabela 7) adquiriram 5,6 bilhões de litros de leite em 2000, o que equivale a $50 \%$ do leite sob inspeção federal. O valor da produção em 1996 para o leite foi de $R \$ 6,4$ bilhões, enquanto que o valor adicionado pelos laticínios foi de $\mathrm{R} \$ 11,0$ bilhões (IBGE,2000a).

O que se percebe, portanto, é que há um afunilamento na cadeia, da produção até o supermercado. Pelo número de participantes e pela não diferenciação da matéria-prima, os produtores assemelham-se a um mercado concorrencial, enquanto a indústria e o supermercado detêm mecanismos de definição de preços.

Além da concentração ao longo da cadeia produtiva, ocorre também concentração em termos de consumo espacial e por faixa de renda. Em 2000 foram consumidos 129 litros por habitante. O recomendado pelo Instituto Nacional de Alimentação e Nutrição é de 146 litros/habitante/ano. Embora com "déficit" em relação ao recomendado, houve um crescimento na década, pois em 1990 o consumo era de 107 litros (Meireles e Alves, 2001).

Tos dados da Pesquisa de Orçamentos Familiares para 1996 (IBGE, 2002), apresentados na Figura 3, mostram a concentração do consumo de leite nas onze regiões metropolitanas - RM pesquisadas. A estimativa é que nessas $\mathrm{RM}$ as familias dispenderam $\mathrm{R} \$ 3,6$ bilhões com leite e derivados em doze 
meses, entre 1995 e 1996. Somente a região metropolitana de São Paulo foi responsável por $36 \%$ do dispêndio, o que ultrapassa o dispêndio conjunto estimado para Porto Alegre, Recife, Curitiba, Salvador, Fortaleza, Distrito Federal, Goiânia e Belém. As famílias das duas principais regiões metropolitanas, São Paulo e Rio de Janeiro, corresponderam a $57 \%$ de todo o consumo estimado.

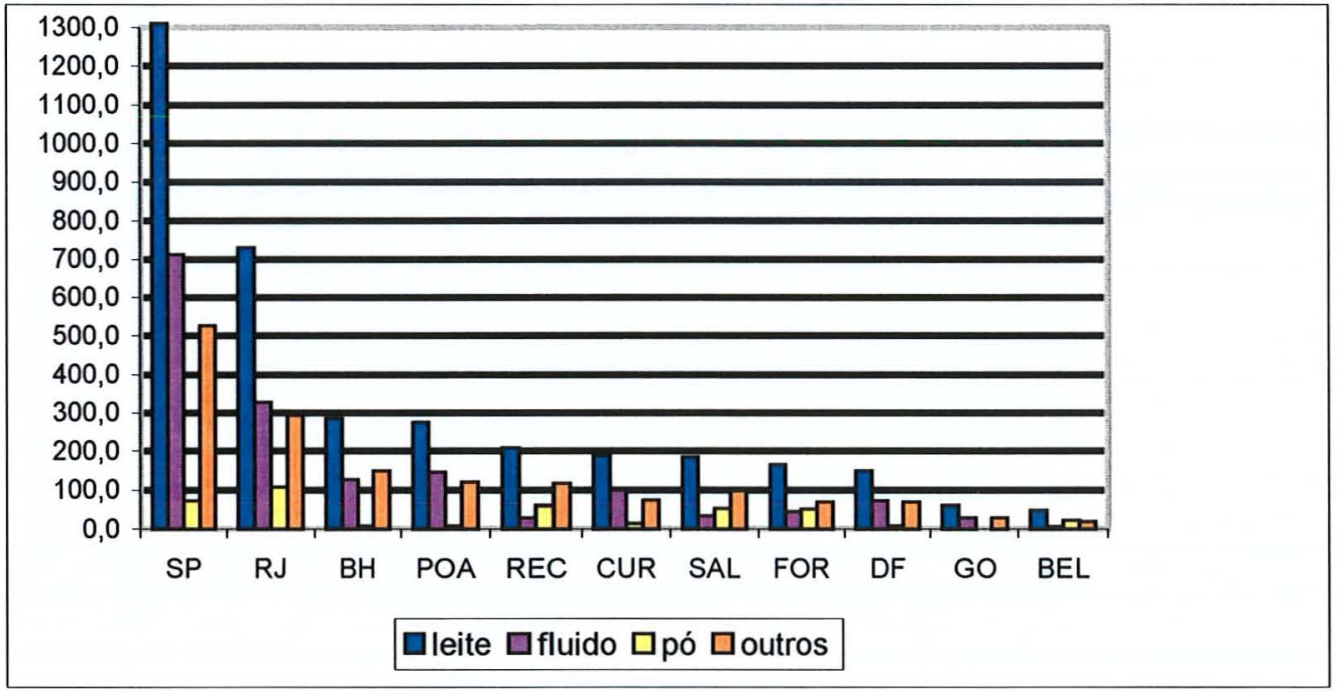

Figura 3 - Dispêndio anual em Reais estimado com Leite, Leite Fluido, Leite em Pó e Demais Derivados em Regiões Metropolitanas Selecionadas, Brasil, 1995-1996.

Fonte: IBGE (2002)

Em termos de consumo de leite fluido, a concentração em São Paulo é ainda maior, correspondendo a $44 \%$ de todo o dispêndio realizado nas RM. Em conjunto com o Rio de Janeiro, o porcentual chegou a $64 \%$. Para o dispêndio com queijos e outros derivados, cerca de 1/3 correspondeu ao consumo de São Paulo, enquanto o de leite em pó foi $17 \%$, menor que o dispendido isolado das RM de Rio de Janeiro, Belo Horizonte, Porto Alegre, 
Curitiba e Distrito Federal. Nas onze RM, o consumo anual estimado foi de R $\$$ 1,63 bilhões para leite fluido, $\mathrm{R} \$ 1,57$ bilhões para queijos e outros derivados e $\mathrm{R} \$ 412$ milhões para o leite em pó. Em termos consolidados, o reduzido dispêndio de Leite em Pó em relação a outras formas de consumo pode ser justificado em função desse produto ser utilizado preferencialmente como insumo de outros produtos e não no consumo final.

A Tabela 10 reproduz a estimativa de dispêndio mensal médio e por habitante nas onze regiões metropolitanas. Verifica-se que é elevado o comprometimento da renda com a aquisição de leite e derivados. Excetuandose Belém, o dispêndio esteve acima de $10 \%$ em relação ao dispêndio com alimentos. Por esse enfoque, São Paulo perdeu sua posição de destaque, pois o gasto mensal médio e per capita com leite foi maior em outras três RM. Mas a pior queda relativa de posição foi no Rio de Janeiro, que se colocou-se na sexta posição.

Tabela 10. Dispêndio mensal per capita estimado com alimentação e leite por Região Metropolitana, Brasil, 1996.

\begin{tabular}{lccc}
\hline $\begin{array}{c}\text { Regiões } \\
\text { Metropolitanas }\end{array}$ & $\begin{array}{c}\text { Alimentação (a) } \\
(\mathrm{R} \$)\end{array}$ & $\begin{array}{c}\text { Leite (b) } \\
(\mathrm{R} \$)\end{array}$ & $\begin{array}{c}\text { (a) /(b) } \\
(\%)\end{array}$ \\
\hline Porto Alegre & 67,92 & 7,52 & 11,1 \\
Distrito Federal & 66,19 & 7,44 & 11,2 \\
Curitiba & 64,24 & 7,09 & 11,0 \\
São Paulo & 64,43 & 6,88 & 10,7 \\
Belo Horizonte & 59,77 & 6,67 & 11,2 \\
Rio de Janeiro & 57,75 & 6,05 & 10,5 \\
Recife & 49,75 & 5,99 & 12,0 \\
Salvador & 53,61 & 5,96 & 11,1 \\
Fortaleza & 47,74 & 5,52 & 11,6 \\
Goiânia & 43,21 & 5,08 & 11,7 \\
Belém & 55,32 & 4,39 & 7,9 \\
\hline
\end{tabular}

Fonte: IBGE (2002) 
A Tabela 10 e a Figura 4 revelam preferências de consumo. Nas RM localizadas nas regiões Sul, Sudeste e Centro-Oeste, é restrito o comprometimento da renda com aquisição de leite em pó. Somente no Rio de Janeiro mais de $10 \%$ dos gastos com leite se deram com este produto. As RM do Norte e Nordeste, por outro lado, valeram-se mais de leite em pó que de leite fluido. Esse é um traço cultural destas regiões, que durante o período de regulamentação, por serem deficitárias em termos de disponibilidade do leite, valiam-se da alternativa de consumo, dada pelo leite em pó. Mesmo com o crescimento do Leite UHT, que viabilizou o consumo de leite fluido em regiões deficitárias, essa prática não foi de todo erradicada, conforme demonstram os dados.

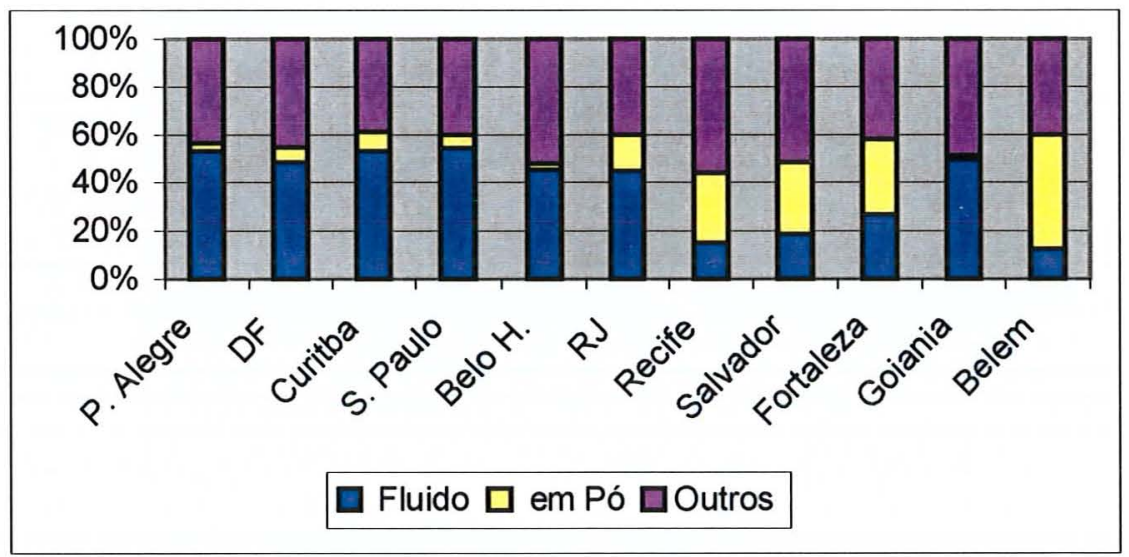

Figura 4 - Percentagem do dispêndio com leite por produto, por RM, Brasil, 1996.

Fonte: IBGE (2002)

Também sob a ótica do consumo per capita e mensal confirma-se a característica de concentraçao de dispêndio e importância do leite no gastos das famílias com alimentos (Figura 4). Os dados consolidados para as onze RM demonstram que o dispêndio com aquisição de leite varia diretamente com 
a renda. As familias com renda de até 2 salários mínimos tiveram dispêndio médio mensal de $R \$ 3,02$ per capita, contra $R \$ 13,02$ daquelas com renda mensal acima de 30 salários mínimos.

Por outro lado, o percentual de comprometimento da renda com aquisição de leite e derivados em relação ao dispendio com alimentação esteve acima de $10 \%$ para oito das dez classes de renda e variou entre $9,4 \%$ e $11,5 \%$.

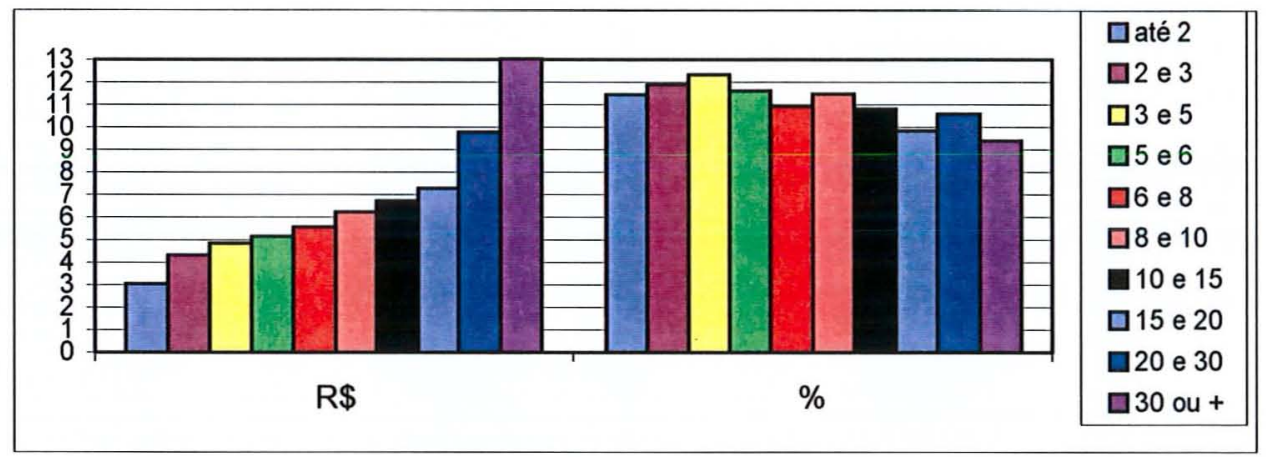

Figura 5 - Dispêndio mensal e per capita com leite e derivados em onze

RM, em Reais e em percentual relativo ao dispêndio com alimentos, por classe de renda.

Fonte: IBGE (2002)

\subsection{Considerações Finais}

São marcantes as diferenças de foco entre os trabalhos analíticos produzidos nos dois períodos: regulamentação e pós-regulamentação. As contribuições geradas até os anos oitenta têm a característica primordial de analisar questões relacionadas a eficiência técnica e econômica da atividade primária. Caracterizam-se por abordagens focadas em economia da produção. Não há discussão intensa sobre os efeitos da atuação do governo e de importações, nem sobre estrutura de mercado, variáveis não consideradas relevantes. 
A partir dos anos noventa a literatura mostra-se mais diversificada e questões relacionadas ao ambiente institucional passam a merecer importante atenção. Decisões de governo relacionadas ao leite passam a ser objeto de análise, bem como a relação entre os diferentes agentes que compõem a cadeia produtiva.

Por outro lado, o SAG do leite nacional teve sua relevância econômica demonstrada, pela sua capacidade de gerar emprego, renda e tributos em praticamente todas as regiões do país. Some-se a isso o tipo de mão-de-obra que emprega no setor primário. De restrita educação formal, é aquela que maiores dificuldades encontra para ser absorvida por setores urbano-industriais. A relevância do SAG é acrescida pelas relações que estabelece com outros setores importantes da economia, motivadas pela intensidade nos vínculos estabelecidos e pelo fato de ser uma cadeia longa, o que se traduz em aquisição de insumos e serviços e de destinação de seus produtos a diferentes setores, não somente a demanda final.

As transformações estruturais da economia, ensejadas ao longo dos anos noventa, trouxeram mais eficiência e dinamismo à cadeia produtiva láctea, até pelas condições competitivas adversas impostas aos agentes, derivadas do câmbio sobrevalorizado, da taxa de juros e da carga tributária elevadas.

Se por um lado a desregulamentação levou a uma intensa busca de ganhos de escala, o que permitiu a redução do preço do leite recebido pelos produtores, levou e tem levado a um processo de dificuldade de sobrevivência daqueles agentes que não perceberam as mudanças em curso, ou não tiveram tempo e condições de se adaptarem. Isso vale tanto para o setor primário, quanto para o setor de transformação, que vem passando por concentração industrial. 
O poder de mercado, representado pelo setor de embalagem para o leite Longa Vida, o crescimento da importância do setor de supermercados na ponta da cadeia e a tendência de oligopolização do setor de transformação parecem sinalizar para a criação de um cenário que demandará, cada vez mais, foco não somente nos custos de produção, mas também nos custos de transação relacionados. 


\section{MERCADO INTERNACIONAL DE LÁCTEOS E O ACORDO AGRÍCOLA DA OMC: UMA REVISÃO ANALITICA}

O presente capítulo tem por objetivo retratar o mercado internacional de leite e derivados, procurando analisar a existência de distorções que afetam a eficiência e a competitividade do produto nacional, frente a produtos importados. Para tanto, na seção 3.1 são apresentadas justificativas para a ocorrência de regulamentação de mercados e instrumentos possíveis de implementação por governos, sob a ótica de impactos no comércio internacional. Na seção 3.2 são reunidas informações visando a montagem do cenário existente no mercado internacional de lácteos.

Na seção 3.3 estão sistematizados os compromissos assumidos ao término da Rodada Uruguai, que visaram a redução de ações inibitórias ao livre comércio entre nações, consubstanciadas no Acordo Agrícola. Na seção 3.4 lança-se mão das idéias contidas na primeira seção para se analisar as políticas de intervenção no mercado de leite e derivados, adotadas em diferentes países e regiões, e como estas políticas foram afetadas com o Acordo Agrícola. Considerou-se, nesse tópico, a literatura internacional, preferencialmente aquela gerada por autores dos países e regiões retratados. $A$ seção 3.5 traz resultados de simulações sobre desregulamentação do mercado de lácteo, obtidas na literatura internacional sobre modelos de equilíbrio geral. A seção 3.6, finalmente, complementa a discussão sobre o tema deste capítulo. 


\subsection{Justificativas para a regulamentação}

Há justificativas para a intervenção do Estado quando o mercado não propicia condições para uma eficiente alocação de recursos. Os principais fatores que afetam o sistema e justificam a intervenção são, dentre outros, a existência de externalidades, de informação assimétrica, de bens públicos e de poder de monopólio.

Considerando a sistemática apresentada por Farina (1997), existindo externalidades, a regulamentação social é requerida. Existem externalidades quando o cálculo privado não equivale ao cálculo social de produção ou de investimento. Esta situação ocorre quando não existem mercados organizados e competitivos, o que impede a efetiva definição de custos e benefícios privados.

Por outro lado, visando preservar o interesse social, justifica-se a intervenção do Estado, quando os agentes atuam na presença de informação assimétrica e imperfeita. Se os agentes participantes de transações não têm a mesma qualidade e quantidade de informações, ou quando os agentes não dominam a lista de informações necessárias para a tomada de decisões, guarda-se uma distância do modelo de concorrência perfeita e há necessidade da presença do Estado.

Uma terceira motivação para a regulamentação sob a ótica social diz respeito aos bens públicos: aqueles que, ao serem produzidos, o número de consumidores não altera o custo de sua provisão, nem é possível a exclusão de consumidores. Nesses casos, o mercado não oferece estímulos eficientes para induzir investimentos necessários.

Um quarto fator que justificaria a intervenção do Estado, derivada de falhas de mercado, mas sob a ótica de regulamentação econômica, diz respeito à possibilidade de agentes usufruírem da condição de poder de monopólio. 
Esta situação ocorre quando um agente ou grupo tem condição de estabelecer preços de mercado. Quando a existência de muitas firmas pode levar à utilização sub-ótima dos recursos, justifica-se a existência de poucas firmas, mas na presença de regulamentação do Estado.

A regulamentação por interesse público visa à correção de falhas de mercado, que levam a economia a se distanciar do equilibrio competitivo e da alocação ótima dos recursos, o que gera um desempenho sub-ótimo em termos de bem-estar social.

Apenas duas organizações alternativas são encontradas na literatura: o mercado e o Estado (Farina, 1997, p.129), sendo que a atividade regulamentatória é uma prerrogativa do Estado. Outras organizações, contudo, que participam na coordenação de atividades econômicas, podem vir a assumir esta função, como sindicatos, associações e até mesmo firmas. As associações de interesse privado não são substitutas nem do Estado, nem do mercado, por guardarem uma racionalidade própria que justificam sua existência (Streek e Schmitter, citados por Farina, 1997). Não há garantia prévia de que a racionalidade privada dos participantes será compatível com a racionalidade pública. Ademais, o poder das associações de se auto governarem necessita de autoridade legitimada pelo Estado ou por consenso, para que ações coercitivas contra seus participantes possam ser implementadas.

De acordo com Saes (1998), a regulamentação dos mercados pode ser também motivada por grupos de interesse. Visa-se, dessa forma, atender a demanda de grupos organizados da sociedade, como a elevação de preços e a diminuição da competição entre os agentes, por exemplo.

Finalmente, a regulamentação neocorporativista considera pressupostos de interesses público e privado. O comportamento dos membros que compõem um grupo de pressão é condicionado por forças competitivas de 
mercado e pela burocracia estatal. A relação entre o público e o privado se dá por uma interação estratégica, ditada pelo jogo de contrários que se estabelece, que pode dar origem a diferentes arranjos, em função das condições históricas vividas por cada uma dessas instituições.

A regulamentação pode valer-se de políticas tarifárias e nãotarifárias, bem como de políticas domésticas. Políticas Tarifárias referem-se a impostos cobrados quando um bem é importado. Tarifas específicas são fixadas e cobradas por unidade do bem importado, enquanto tarifas ad valorem são impostos cobrados em relação ao valor do bem importado.

Na presença de livre comércio, o preço local vigente para um produto deverá ser o mesmo que o verificado nas demais nações. Caso esse preço leve a uma demanda interna superior à quantidade ofertada, o equilibrio do mercado interno se dará pela importação da quantidade necessária ao ajuste.

Por seu turno, a adoção de uma tarifa sobre as importações leva a desequilibrios nos diferentes mercados e, portanto, à perda de eficiência. No mercado local, que sofreu o impacto da tarifa, haverá uma elevação de preços, resultando no aumento da produção e na redução do consumo e da quantidade importada. Supondo-se que essa economia tem algum poder de mercado em relação aos demais países, o preço externo cairá.

Com efeito, ao se supor equilibrio com pleno emprego e combinação eficiente de fatores, a adoção de uma tarifa leva a um aumento da produção local, em detrimento da produção mundial. O efeito de uma tarifa leva, portanto, à proteção de produtores locais, ao inibir a concorrência de produtos importados, e em algum nivel, a uma redução de eficiência na alocação de recursos, tanto na economia local, agora protegida pela tarifa, quanto na economia mundial. 
Resultados semelhantes ao descrito são obtidos no mercado local quando se adotam subsídios à exportação. A redução artificial dos preços de comercialização no mercado internacional dota de maior competitividade os produtos do país que subsidia, aumentando a demanda internacional pelo seu produto. A produção no mercado local tenderá a se elevar, em detrimento da produção internacional, que será inibida. Por outro lado, quando o imposto incide sobre as exportações, os produtores são prejudicados.

Quanto a barreiras não-tarifárias, a adoção de sistemas de cotas de importação restringe a quantidade importada de um bem. A emissão de autorizações para importar é destinada a grupos de indivíduos ou empresas, levando a ganhos privados. Além disso, os produtores se beneficiam, pois o preço interno do produto se eleva (Krugman \& Obstfeld, 2001). A limitação da importação leva a um excesso de demanda, que se reflete na elevação dos preços.

Uma variante das cotas de importação é a restrição voluntária as exportações. Por este instrumento o país exportador define a quantidade do produto a ser exportada. É implementada visando salvaguardar o seu mercado interno, ou o do país importador, quando essa se dá por negociações entre governos. Nos dois casos, o produtor do pais importador é beneficiado, ao se limitar a importação. Dois outros instrumentos compõem o conjunto clássico de barreiras não-tarifárias: comércio estatal - quando somente empresas do governo podem promover importações, e controles cambiais, estes ocorrendo por liberação de licenças para importação, ou por manutenção da moeda desvalorizada.

Praticas impostas pela burocracia, bem como exigências fitossanitárias aos produtos importados, vêm ganhando importância como mecanismos não-tarifários de restrição ao comércio, principalmente após o 
término da Rodada Uruguai, quando as nações acordaram restrições à adoção de barreiras não-tarifárias clássicas.

Programas de preço mínimo, subsídio ao consumo ou à produção, e políticas de discriminação de preços efetivadas pelos governos são importantes instrumentos limitantes ao livre comércio e, portanto, agem em favor da proteção de produtores menos eficientes. Quando se trata de grandes economias, essas práticas interferem diretamente no mercado internacional.

\subsection{Mercado internacional de lácteos}

O leite é produzido em todos os países do mundo e políticas de intervenção específicas são adotadas, visando a preservação da saúde e/ou a renda dos consumidores, ou a proteção de interesses de agentes que participam da cadeia produtiva, principalmente os produtores. Políticas de cunho protecionista contribuem para que somente $5 \%$ da produção mundial de lácteos seja transacionada no mercado mundial (Turnbull, 1999). Dentre os produtos agrícolas, o setor lácteo é um dos mais altamente subsidiados, tanto em termos de mercado interno, quanto em termos de mercado internacional (Bailey, 1997). Subsídios a produção doméstica, barreiras à importação e subsídios à exportação criam um cenário de distorções no mercado internacional de lácteos, que afeta a economia dos países de maneira diferenciada.

Três tipos de políticas são largamente adotadas pelos países, no comércio de lácteos: políticas domésticas, de importação e de exportação. No âmbito doméstico são adotados subsídios à produção, ao consumo, controle de produção, preço mínimo e esquemas de discriminação de preços. A União Européia (UE), por exemplo, subsidia o leite em pó destinado ao consumo humano e animal e estoques de manteiga. Estados Unidos, Japão e UE utilizam a merenda escolar como mecanismo de sustentação da demanda por lácteos. Já a Nova Zelândia e a Austrália subsidiam insumos usados pelos fazendeiros 
(Zhu et al., 1999). Práticas como essas aumentam a demanda ou reduzem a oferta doméstica de lácteos, o que afeta positivamente o preço interno.

Políticas de importação dizem respeito a barreiras tarifárias e não tarifárias, visando limitar as importações de lácteos. São exemplos de barreiras não tarifárias as cotas de importação para derivados lácteos, preço mínimo permitido para a comercialização de derivados lácteos importados no mercado interno, e licenças discricionárias para importação, dentre outras. As tarifas podem ser sobre o valor (ad valorem) ou sobre um montante fixo por unidade importada, ou a combinação de ambas. Enquanto as barreiras tarifárias têm impacto indireto sobre o volume importado, por meio do efeito-preço, as barreiras não tarifárias restringem o comércio diretamente, afetando o volume importado.

Políticas de exportação incluem instrumentos que estimulam direta ou indiretamente a colocação de lácteos no mercado mundial e estão intimamente relacionadas com as políticas domésticas e de restrição à importação. A existência de excedente exportável, gerado por preços mínimos elevados e por dificuldades impostas à importação, leva os países a destinar estoques ao mercado internacional. $\mathrm{Na}$ ausência dessas políticas, o excedente exportável impactaria o mercado internacional e as economias domésticas ao mesmo tempo. Na presença de distorções ao livre comércio, o impacto recai somente sobre o mercado internacional. Os países que sofrem a ação desencadeada por outros, arcam com o ônus das distorções, quanto menores forem seus mecanismos de proteção ao mercado interno de lácteos.

Os dados apresentados nas Tabelas 11 a 13 demonstram que a produção e o comércio mundiais são concentrados em poucos países. Os vinte maiores produtores foram responsáveis por $74 \%$ da produção mundial em 1999 , sendo que os oito maiores países produtores responderam pela metade da produção mundial. Os vinte maiores exportadores líquidos de lácteos 
naquele ano exportaram US\$ 11,3 bilhões, que equivaleram a $86 \%$ das exportações mundiais. Os sete maiores exportadores foram responsáveis por $66 \%$ das exportações mundiais. Por outro lado, os vinte maiores países importadores líquidos foram responsáveis por $65 \%$ das aquisições de lácteos.

Tabela 11. Principais países produtores de leite, 1999.

\begin{tabular}{clcc}
\hline Posição & \multicolumn{1}{c}{ Variável } & Produção (bilhões de litros) & \% da produção mundial \\
\hline & Mundo & 489,1 & 100,0 \\
01 & Vinte Maiores & 362,8 & 74,2 \\
02 & IUA & 73,8 & 15,1 \\
03 & Federação Russa & 36,0 & 7,4 \\
04 & Alemanha & 32,0 & 6,5 \\
05 & França & 28,3 & 5,8 \\
06 & Brasil & 24,9 & 5,1 \\
07 & Reino Unido & 21,7 & 4,4 \\
08 & Ucrânia & 15,0 & 3,1 \\
09 & Polônia & 13,2 & 2,7 \\
10 & Itália & 12,3 & 2,5 \\
11 & Holanda & 11,7 & 2,4 \\
12 & Nova Zelândia & 11,7 & 2,4 \\
13 & Argentina & 10,9 & 2,2 \\
14 & Austrália & 10,6 & 2,2 \\
15 & México & 10,5 & 2,1 \\
16 & Turquia & 9,2 & 1,9 \\
17 & Japão & 8,8 & 1,8 \\
18 & Canadá & 8,5 & 1,7 \\
19 & Paquistão & 8,2 & 1,7 \\
20 & China & 8,0 & 1,6 \\
\hline
\end{tabular}

Fonte: Brandão \& Leite (2001) 
Tabela 12. Maiores exportadores líquidos em equivalente leite, 1999.

\begin{tabular}{clc}
\hline Posição & País & Exportação (US\$ milhão) \\
\hline 1 & Nova Zelândia & 1.947 \\
2 & França & 1.891 \\
3 & Holanda & 1.394 \\
4 & Austrália & 1.273 \\
5 & Dinamarca & 1.253 \\
6 & Alemanha & 1.231 \\
7 & Irlanda & 926 \\
8 & Argentina & 333 \\
9 & Uruguai & 154 \\
10 & Suiça & 143 \\
11 & Austria & 129 \\
12 & Finlândia & 110 \\
13 & Lituânia & 105 \\
14 & República Tcheca & 100 \\
15 & Polônia & 91 \\
16 & Bielo-Rússia & 71 \\
17 & Noruega & 63 \\
18 & Ucrânia & 50 \\
19 & Zona de Gaza & 41 \\
20 & África do Sul & 36 \\
\hline
\end{tabular}

Fonte: Brandão \& Leite (2001)

Tabela 13. Maiores importadores líquidos em equivalente leite, 1999.

\begin{tabular}{clc}
\hline Posição & País & Importação (US\$ milhão) \\
\hline 1 & Itália & 1.705 \\
2 & EUA & 769 \\
3 & Reino Unido & 758 \\
4 & Japão & 737 \\
5 & Argélia & 514 \\
6 & México & 488 \\
7 & Espanha & 437 \\
8 & Brasil & 436 \\
9 & Arábia Saudita & 374 \\
10 & Grécia & 372 \\
11 & China & 345 \\
12 & Filipinas & 331 \\
13 & Indonésia & 241 \\
14 & Malásia & 219 \\
15 & Federação Russa & 218 \\
16 & Tailândia & 217 \\
17 & Nigéria & 217 \\
18 & Hong Kong & 188 \\
19 & Egito & 178 \\
20 & Bélgica - Luxemburgo & 163 \\
\hline
\end{tabular}

Fonte: Brandão \& Leite (2001) 
As Tabelas referidas sinalizam a importância da União Européia no mercado mundial. Quatro paises membros colocaram-se entre os vinte maiores produtores em 1999, respondendo por $18 \%$ da produção mundial. Por outro lado, oito países membros daquele bloco estão entre os vinte maiores exportadores líquidos e contribuiram com $62 \%$ do total exportado pelos vinte maiores exportadores. Dentre os sete maiores, cinco países são membros da União Européia.

Com o propósito de medir o grau de subsidios aplicados aos produtos, a Organização para a Cooperação e Desenvolvimento Econômico OCDE desenvolveu o conceito de Subsídio de Equivalência ao Produtor - SEP. No caso do leite, no período que antecede ao Acordo Agrícola assinado ao final da Rodada Uruguai, os diferentes países apresentaram elevada taxa de proteção a seus mercados domésticos, o que dificultava a importação de produtos lácteos, a exceção da Nova Zelândia (Tabela 14).

Tabela 14. Subsídio equivalente ao produtor de leite em países da OCDE.

\begin{tabular}{lcccc}
\hline & Média $1979-86(\%)$ & $1987(\%)$ & $1990(\%)$ & $1993(\%)$ \\
\hline Japão & 82 & 90 & 87 & 89 \\
Noruega & 77 & 78 & 81 & 82 \\
Suíça & 72 & 83 & 84 & 81 \\
Finlândia & 64 & 74 & 74 & 75 \\
Canadá & 64 & 77 & 81 & 70 \\
Áustria & 46 & 59 & 64 & 67 \\
Suécia & 65 & 72 & 74 & 66 \\
União Européia & 51 & 72 & 55 & 64 \\
EUA & 61 & 64 & 61 & 53 \\
Austrália & 28 & 29 & 34 & 26 \\
Nova Zelândia & 21 & 13 & 03 & 02 \\
OCDE & 58 & 66 & 68 & 62 \\
\hline
\end{tabular}

Fonte: OCDE (1994)

Nota: Suiça, Finlândia, Áustria e Suécia são atualmente membros da UE. 
A produção mundial de leite apresentou tendência de elevação em países em desenvolvimento, enquanto que o inverso ocorreu em países desenvolvidos, no período que antecede a assinatura do Acordo Agrícola (Tabela 15). A taxa anual de crescimento média dos países em desenvolvimento foi quase cinco vezes maior que a dos países desenvolvidos, entre 1982 e 1994, e quase o dobro da taxa anual média mundial. Mesmo ainda registrando crescimento vegetativo populacional, a produção per capita nos países em desenvolvimento cresceu $22 \%$ em 12 anos, contra uma reduzida redução da produção per capita nos países desenvolvidos. De acordo com Delgado et al. (1999), entre 1983 e 1993 os países em desenvolvimento aumentaram sua participação relativa na produção mundial de $24 \%$ para $32 \%$.

Tabela 15. Comportamento da produção de leite por regiões, 1992-1994.

\begin{tabular}{lccc}
\hline & $\begin{array}{c}\text { Taxa anual de crescimento } \\
\text { da produção (\%). }\end{array}$ & $\begin{array}{c}\text { Produção k/per } \\
\text { capita 1983 }\end{array}$ & $\begin{array}{c}\text { Produção k./per } \\
\text { capita 1993 }\end{array}$ \\
\hline China & 8,4 & 3 & 6 \\
Índia & 3,7 & 51 & 66 \\
América Latina & 2,9 & 94 & 101 \\
Em Desenvolvimento & 5,4 & 32 & 39 \\
Desenvolvidos & 1,1 & 305 & 272 \\
Mundo & 2,9 & 102 & 93 \\
\hline
\end{tabular}

Fonte: Delgado et al. (1999)

O crescimento na produção entre os paises em desenvolvimento não foi suficiente para reverter o quadro de concentração de consumo. Em 1983 os países desenvolvidos consumiram per capita 2,6 vezes mais leite do que a média mundial. Quando a comparação é feita com os países em desenvolvimento o consumo per capita dos países desenvolvidos é 5,6 vezes maior. Em 1993, essas relações pouco se alteraram (Tabela 16). 
Tabela 16. Consumo per capta de leite em litros por regiões, 1983-1994.

\begin{tabular}{lcc}
\hline & 1983 & 1993 \\
\hline China & 3 & 7 \\
India & 46 & 58 \\
América Latina & 93 & 100 \\
Em Desenvolvimento & 35 & 40 \\
Desenvolvido & 195 & 192 \\
Estados Unidos & 237 & 253 \\
MUNDO & 76 & 75 \\
\hline
\end{tabular}

Fonte: Delgado et al. (1999)

\subsection{Rodada Uruguai e a implementação do Acordo Agrícola em países e regiões selecionados}

O Acordo Geral sobre Tarifas e Comércio - GATT, foi criado em 1947 para reorganizar o comércio mundial e reduzir procedimentos protecionistas adotados de maneira generalizada, que levavam os países a um distanciamento dos pressupostos do livre comércio. Em 49 anos de existência, o GATT promoveu oito rodadas de negociações multilaterais (Gonçalves et. al.,1998). A última, denominada Rodada Uruguai, iniciou-se em 1986 e culminou com um acordo de liberação do comércio, assinado inicialmente por 128 paises, em 1994.

\subsubsection{Medidas acordadas}

A Rodada Uruguai foi a maior negociação comercial de âmbito mundial já realizada. Ao final, ocorreram mudanças institucionais importantes, com a extinção do GATT e a criação da Organização Mundial do Comércio OMC. Além disso, no momento em que vários acordos comerciais bilaterais eram negociados e/ou implementados, garantiu-se a sobrevivência das negociações multilaterais. Sua grande marca, contudo, foi ter incluído, pela primeira vez, o setor agropecuário no âmbito dessas negociações. Isso contribuiu para o atraso no encerramento das negociações em quatro anos, 
face às dificuldades de se chegar a posições que atendessem aos interesses dos países participantes.

Ao término das negociações, foi firmado o Acordo Agrícola, que estabeleceu normas relativas a três temas: acesso a mercados, políticas de apoio interno e subsídios às exportações. Vigente a partir de 1995, definiu-se um prazo de seis anos de implementação para os paises desenvolvidos e de dez anos para países em desenvolvimento.

\section{3.1.1 Acesso a mercados}

Ficou estabelecido que seriam eliminadas todas as barreiras nãotarifárias, pelo mecanismo de "tarificação", ou seja, essas barreiras deveriam ser convertidas em tarifas, visando tornar mais transparentes as medidas inibitórias a importação de produtos agrícolas. As barreiras não-tarifárias seriam transformadas em um "equivalente tarifário", que resultaria em uma tarifa que desse proteção equivalente às barreiras não tarifárias então existentes. A estimativa do equivalente tarifário seria dada pela diferença entre o preço vigente no mercado interno do produto protegido e o preço praticado no mercado internacional. Além disso, após essa conversão, haveria uma redução dos níveis tarifários em pelo menos $36 \%$ na média dos produtos agricolas de cada país, e em $15 \%$ por produto, no mínimo, em países desenvolvidos. Nos países em desenvolvimento as reduções deveriam ser, respectivamente, de $24 \%$ e $10 \%$.

Tendo por período-base as tarifações vigentes em setembro de 1986 e os preços praticados entre 1986 e 1988 para definição de alíquotas, considerando-se a possibilidade do processo de "tarificação" resultar em tarifas proibitivas para produtos específicos, estabeleceu-se ainda o dispositivo chamado de "acesso mínimo" dos produtos aos mercados domésticos. Visouse, dessa forma, assegurar que os novos procedimentos garantiriam o acesso dos produtos importados, em 3\% no mínimo, de cada mercado, em 1995. Nos 
anos subsequentes, previu-se um acréscimo de $0,4 \%$ ao ano, até que se atingisse $5 \%$ em 2000.

\subsubsection{Medidas de apoio interno}

Face à amplitude de instrumentos de suporte usualmente adotados pelos países e que têm efeitos distorcivos no comércio internacional, o Acordo Agrícola classificou-os em dois grupos.

O primeiro grupo, denominado de Caixa Verde, é composto por medidas que não se destinam a produtos específicos e não interferem no funcionamento dos mercados. Essas medidas estão autorizadas e devem ser implementadas com recursos públicos - o que inclui renúncia fiscal. Por outro lado, não deverão objetivar a sustentação de preços. São exemplos de medidas autorizadas: serviço de inspeção sanitária, educação rural e infra-estrutura pública; estoques de segurança alimentar; programas sociais de ajuda alimentar; seguro agricola; programas ambientais e de desenvolvimento regional; e, pagamentos diretos e sustentação de renda dos produtores, desde que não seja proporcional à quantidade produzida.

O segundo grupo é formado por medidas que distorcem os mercados e que deveriam ser reduzidas. São exemplos as políticas de sustentação de preços, como preços administrados, preços mínimos e políticas que levem à redução de custos de produção ou de comercialização. O Acordo Agrícola estabeleceu uma redução monetária de $20 \%$ sobre o montante de ajuda dada a cada produto, caso tal ajuda tenha sido superior a $5 \%$ do valor da produção no período-base em países desenvolvidos, e a $10 \%$ do valor da produção no período-base, nos países em desenvolvimento. 


\subsubsection{Estímulo à exportação}

O Acordo Agrícola estabeleceu redução mínima de $36 \%$ do montante monetário concedido como estímulo à exportação e um mínimo de redução de $21 \%$ da quantidade do produto subsidiada, em países desenvolvidos. Em países em desenvolvimento os valores são, respectivamente, $24 \%$ e $14 \%$. Foram considerados subsidios o uso de práticas comerciais como: subsídios diretos à produção agrícola voltada para o mercado externo; subsídios diretos à exportação ou a comercialização de produtos exportáveis; subsídios ao frete interno ou a insumos usados em produtos voltados para o mercado externo; e, comercialização de estoques públicos a preços inferiores aos praticados no mercado doméstico.

\subsection{Políticas de regulamentação e o Acordo Agrícola por países e regiões selecionados}

\subsubsection{Estados Unidos da América}

A atividade láctea nos EUA vem passando por constantes transformações. O número de vacas caiu de 12 milhões em 1970 para 9,2 milhões em 2000, e 9,1 milhões em 2001, enquanto que a produtividade anual, medida por vaca, cresceu de 4,4 mil quilos para 8,3 mil quilos em igual período. Em 2001 existiam 80 mil propriedades leiteiras, com perspectivas de se estabilizar entre 30 e 50 mil (Brooks, 2001).

As transformações no SAG do leite americano começaram logo após o término na II Grande Guerra, com a substituição da pequena produção e do pequeno laticínio por propriedades e plantas industriais com maior produção e processamento. Objetivou-se a obtenção de ganhos por meio de economias de escala. A adoção do sistema de granelização na captação do leite contribuiu decisivamente para que ocorresse a exclusão de produtores que não se adaptaram a um novo cenário de uso intensivo de tecnologia e de 
procedimentos administrativos. Fato similar ocorreu com os laticínios, que contavam 4.103 em 1964 e eram 640 em 1988 (Bailey, 1997). De janeiro de 1998 a março de 2002 a Indústria de Laticínios americana esteve envolvida em 143 fusões e aquisições. Dessas, 127 ocorreram nos EUA e 16 no restante do mundo, mas por empresas americanas (Newsletter Milkpont, 2002)

As cooperativas de leite apresentam um significativo domínio do mercado lácteo norte-americano. Entre 1964 e 1992 cresceram sua participação de $67 \%$ para $82 \%$ do leite comercializado. Em igual período, contudo, ocorreu concentração no número de cooperativas, que passaram de 1.244 para 265 .

Apesar do SAG do leite ter faturado US\$ 28,4 bilhões em 1984, o que correspondeu a $0,28 \%$ do $\mathrm{PIB}$, nenhum outro produto agrícola é tão regulamentado nos EUA (Bailey, 1997; Hammond, 1996). A regulamentação iniciou-se na Grande Depressão. A queda do poder aquisitivo das famílias durante a depressão econômica comprimiu o preço dos produtos lácteos em $31 \%$. Face as pressões dos produtores de leite, o Congresso americano aprovou legislação que introduziu a política de preço mínimo. Esperava-se que essa decisão tivesse caráter temporário. Tornou-se permanente, contudo, por meio de diferentes legislações que se seguiram.

Sob a ótica do consumo, os derivados lácteos apresentam características de demanda inelástica, não ocorrendo pressão por parte dos consumidores para o estabelecimento de políticas regulatórias que garantam preços baixos. A demanda social é por intervenção pública quanto à garantia de produtos saudáveis em termos sanitários.

O primeiro grupo de interesse dos produtores foi criado em 1915. O Conselho Nacional de Lácteos tinha o propósito de enfatizar a importância do leite na dieta humana. Atualmente, esse conselho financia pesquisas e eventos científicos e dissemina informações sobre lácteos. Em 1940 os produtores 
criaram a Associação Americana de Lácteos, também com propósitos semelhantes, além de dar sustentação técnica aos produtores. Em 1971 foi criada a Associação da Indústria Láctea Unida, com a finalidade de coordenar as ações das duas entidades citadas, evitando a duplicidade de ações. Mantida por contribuições voluntárias de produtores e processadores, conta com orçamento anual de US $\$ 40$ milhões. Os produtores e processadores também contribuem para a manutenção de dois fundos estatais: o Conselho Nacional para Produção e Pesquisa Láctea e o Conselho Nacional de Processadores de Leite Fluido. Ambos promovem campanhas visando o aumento do consumo de leite e derivados. O primeiro tem como receita US $\$ 0,05$ para cada 100 libras/pound de leite comercializado nos EUA, enquanto que o segundo recolhe US $\$ 0,20$ para cada 100 libras, por um período de seis meses no ano. (Bailey, 1997).

A intervenção de Estado americano no mercado lácteo traduz um reconhecimento quanto à dificuldade de se conciliar os interesses de produtores, processadores e consumidores via mercado. A politica setorial tem como base uma estrutura de preços administrados, o que inclui preços mínimos pagos aos produtores, discriminação de preço - tendo como base o destino dado ao leite (consumo fluido ou fabricação de derivados), e a adoção de um preço comum a todos produtores atuantes num mercado específico.

Essa política promoveu fortes incentivos ao aumento da produção, pois assegurou preços acima daqueles que seriam obtidos sem a intervenção. (Réquillart, 1999). A distorção resulta em constantes excedentes, que variaram de $4,5 \%$ a $12,4 \%$ entre 1980 e 1994 . A eliminação do excesso de oferta se deu nesse período a um custo orçamentário de US\$ 269 milhões a US $\$ 2,6$ bilhões. (Bailey, 1997).

A discriminação de preços também contribui para a manutenção de preços elevados no mercado doméstico, estimulando a produção, que conta 
com o estímulo adicional advindo da dificuldade de importações (Summer, 1999). O leite fluido tem diferencial de preço acima do preço pago ao leite destinado a transformação em derivados. O preço do leite fluido difere em cada região, enquanto que o preço do leite destinado à indústria tem cotação nacional. As áreas delimitadas para a fixação de preços eram de 33 até o término da Rodada Uruguai. Quanto maior a proporção de leite comercializado na forma fluida, maior é o preço pago ao produtor, que é idêntico para todos na mesma região.

Além de medidas federais de intervenção, os estados apresentam legislações complementares, que visam inibir a competição entre regiões. A justificativa para esse procedimento é que a competição foi a causa da crise láctea durante a Grande Depressão e resultou em perda de renda para os produtores. Por outro lado, as autoridades estaduais exercem permanentes auditorias nas contas dos laticínios e aplicam sanções, caso sejam confirmadas ações oportunistas em detrimento dos interesses dos produtores. (Hammond, 1996).

A manutenção de preços domésticos elevados estimularia também importações. Por essa razão, desde 1935 foi imposta uma política de cotas de importação. Ações restritivas foram intensificadas a partir de 1951, sob o argumento de que os preços internacionais são artificiais. Visando salvaguardar os interesses dos produtores, o sistema de cotas de importação é de responsabilidade direta da Secretaria de Estado da Agricultura (USDA), que considera, em suas decisões, os mercados interno e externo para diferentes derivados lácteos.

O freqüente excesso de oferta levou a criação do Programa de Incentivo à Exportação de Derivados Lácteos, com base na Lei de Segurança Alimentar, em 1985. Esse programa visa reduzir os custos da política de preços mínimos e desenvolver mercado para produtos lácteos americanos. A 
justificativa formal para a adoção de subsídios à exportação é que a União Européia distorce os preços internacionais de leite e derivados com subsídios a exportação, sendo necessário compensar essa interferência para que os produtores americanos se tornem competitivos. Anualmente são eleitos produtos e países a serem atingidos pela exportação subsidiada americana. São considerados o excedente interno por derivados e o objetivo de expandir a exportação para países específicos. Agentes privados são autorizados a proceder negociação de contratos de comercialização, após a definição de recursos alocados por produto e país alvo. Antes da adoção dessa política, a experiência americana na exportação de lácteos era insignificante, fato que se modificou a partir de então, chegando a US\$ 520 milhões em 1999. (Hammond, 1996; Brandão \& Leite, 2001).

Sob a influência do Acordo Agrícola resultante da Rodada Uruguai, os EUA promoveram modificações em sua política de atuação no mercado de leite e derivados. Barreiras não tarifárias à importação, tais como cotas e acordos de restrição voluntária à exportação, foram convertidas em tarifas e reduzidas em 15\% - o mínimo aceito pelo Acordo Agrícola, por ter sido o setor de lácteos considerado sensível e merecedor de atenção especial. A garantia de mínimo acesso de $5 \%$ para produtos importados foi atingida, embora com intensas controvérsias na definição de equivalência de leite utilizada na obtenção dos derivados e na determinação de preços domésticos que poderiam ser praticados para produtos importados. O programa de preços mínimos seria extinto em 1999 e em seu lugar surgiria um programa de empréstimos do governo para que a indústria de laticínios promovesse a estocagem de produtos lácteos (AFPC, 1997). Essa extinção, contudo, ainda não aconteceu.

A redução tarifária de $15 \%$ não se deu linearmente. Ao contrário, foi resultante de redução de aliquotas adotadas diferentemente para cada derivado lácteo. A importação de manteiga foi liberada, pois os preços internos vigentes 
não são atrativos à importação. Para o leite em pó e o queijo, por outro lado, foram fixadas tarifas que praticamente proibem importações (IATRC, 1997).

Quanto ao subsidio à exportação, houve redução de $21 \%$ em volume e $36 \%$ em recursos, conforme preconiza o Acordo Agrícola. Manteve-se, contudo, a discriminação de preços por destinação dada ao leite. Foi mantida a regionalização do mercado interno, mas houve uma redução de 33 para 14 regiões que, em essência, caracterizam diferentes mercados, com preços e estruturas distintas de intervenção. (AFPC, 1997).

Em suma, as adaptações processadas para que a política destinada ao leite ficassem em conformidade com o Acordo Agrícola, não produziram significativas mudanças no mercado norte-americano. O leite continua tendo mercado fortemente protegido. Ainda assim, em 2000 foi criado um fundo com o objetivo de ajustar os produtores de leite às mudanças na regulamentação. Com a legislação agrícola de 2002 - o Farm Bill, ficou estabelecido o Contrato de Perda de Rendimento com o Leite. Esse programa prevê repasse de recursos aos produtores, quando o preço do leite cair abaixo de US $\$ 0,373$ o litro. O produtor recebe $45 \%$ da diferença entre esse valor e o menor preço recebido. Em 2002, cerca de 30,1 mil produtores estão recebendo cerca de US $\$ 962$ milhões, correspondendo a US $\$ 0,068$ por litro produzido.

\subsubsection{União Européia}

A União Européia (UE) é a maior exportadora e importadora de produtos agrícolas e alimentares do mundo. Com 15 membros a partir de 1995 e com a previsão de entrada de mais dez países, sua política agrícola doméstica tem impacto em todo o mundo. As exportações agrícolas são dominadas por vendas subsidiadas geradas pela Política Agrícola Comum PAC, que depreciam os preços internacionais e desestabilizam o mercado mundial (Swinbank, 1996). 
A UE responde por cerca de $1 / 3$ do leite exportado no mundo. Como exemplo, em 1995 importou 9\% de todo o volume de manteiga comercializado internacionalmente e exportou $32 \%$, importou $0,5 \%$ do volume de leite em pó e exportou $22 \%$ e importou $12 \%$ do volume de queijos e exportou $52 \%$. Ao todo, importou $2 \%$ e exportou $33 \%$ do volume de lácteos transacionados no comércio mundial. (Swinbank, 1996).

O desenho da intervenção é configurado pela PAC. Estabelecida em 1950, a PAC é fruto de discussão iniciada logo ao término da II Grande Guerra, relativa a uma integração agrícola entre países europeus. Até então, Bélgica, Luxemburgo, Alemanha, França e Itália eram deficitárias em termos de balança comercial agrícola. Somente a Holanda mostrava-se superavitária. Dois objetivos foram então perseguidos: segurança alimentar e garantia de renda para os fazendeiros. A elevada dependência às importações, somada à carência de divisas nos anos subsequentes ao final do conflito bélico, deram aos defensores da proposta de criação de uma política de intervenção por meio da PAC, os argumentos econômicos necessários (Zobbe \& Rolighedsveje, 2002).

Ao longo dos anos sessenta foi criada a união tarifária, visando assegurar livre circulação de produtos agrícolas entre os seis países. A estabilidade de preços foi assegurada por meio de um sistema de intervenção, que manteve continuamente os preços elevados para os produtores. Isso foi possivel principalmente pela adoção de um sistema de impostos à importação, com alíquotas variáveis, dependente do preço alvo estabelecido para cada período.

No caso do leite, por meio da PAC, a UE estabeleceu um complexo conjunto de medidas, desenhadas para assegurar um padrão de vida para os produtores europeus. Esse conjunto de políticas tem com ponto central o preço 
alvo, que visa cobrir os custos de produção e assegurar condições de vida favoráveis aos produtores de leite.

Para que os preços de mercado interno estejam próximos do preço alvo, a PAC estabelece preços mínimos, restrições a importação, aquisições governamentais e subsídio à exportações. Esses instrumentos asseguram preços domésticos superiores ao mercado internacional, bem como competitividade ao produto exportado. Restrições a importações são usados para limitar o consumo de derivados lácteos não produzidos pelos países que compõem a UE. Os produtos importados de outros países são comercializados internamente a preços equivalentes aos vigentes no mercado doméstico, o que limita as importações.

As aquisições governamentais surgem como reflexo da manutenção de preços mínimos, que é mais elevado que os preços do mercado internacional. A garantia da aquisição do excesso de oferta tem resultado em sua manutenção. Com preços atrativos assegurados e sem riscos de comercialização, a produção mantém-se superior à demanda interna. Um instrumento de política usado para reduzir o custo de estocagem tem sido o uso de subsídios à exportação. Claramente, sem esse mecanismo, a UE não seria competitiva no mercado internacional de lácteos. Os subsídios aos produtos exportados totalmente financiados pelos produtores desde 1977, por meio de uma contribuição que varia entre 0,5\% e 3\% do preço alvo. (Bailey,1997).

Outro procedimento que visa atuar sobre o excesso estrutural de oferta está relacionado ao sistema de cotas de produção de leite. Sua implantação se deu pelo crescimento da oferta, o que gerou necessidades crescentes de recursos destinados à política de aquisição governamental e exportação subsidiada. Entre 1973 e 1981 a produção de leite cresceu na UE a uma taxa anual de 2,5\%. Entre 1982 e 1983 a taxa se elevou para 3,5\% ao ano, enquanto desde os anos setenta o consumo tem se mostrado estagnado ou em 
queda eventual. Em 1983, a produção foi de 104 bilhões de litros contra um consumo de 84 bilhões. Em 1984, por outro lado, os gastos com compras e subsídios à exportação de leite chegaram ao equivalente a US\$ 2,3 bilhões e US $\$ 1,7$ bilhão, respectivamente, em valores correntes de 1984. Esse montante correspondeu a $30 \%$ de todo o montante da PAC naquele ano. (Cardwell, 1996).

Em 1984 foi introduzido o sistema de cotas de produção, com o objetivo de limitar o montante de estoque resultante da política de intervenção. Algumas mudanças estruturais ocorreram a partir de então. Entre 1985 e 1997 a produtividade média por vaca se elevou de 4,5 mil quilos/ano para 5,4 quilos/ano. O número de vacas declinou em $20 \%$ e o número de fazendas produtoras caiu de 1,6 milhão para 668 mil, em igual período. Continua, contudo, ocorrendo excesso de oferta, estimado em 12 bilhões de litros em 1996. Para ser exportado, o excedente demandou US $\$ 2,1$ bilhões em 1996 ou cerca de $45 \%$ do orçamento destinado a política do leite. Além disso, somente com estocagem e aquisição de manteiga e leite em pó foram gastos US $\$ 1,9$ bilhões naquele ano. (Benjamin \& Guyomard, 1999).

A intervenção do Estado no setor de leite e derivados, no âmbito da UE, não visa a promoção do interesse público (Guyomard et al. 1993). A justificativa para o formato das políticas voltadas aos lácteos é que há uma função social nelas embutidas, pois visam a manutenção da renda dos produtores, por meio de transferência de renda urbana para o meio rural. A meta é assegurar nivel de vida com qualidade para a comunidade agrícola, particularmente estimulando que a população jovem continue engajada no setor primário de produção.

Reduções no grau de intervenção são difíceis de serem implementadas. Primeiro, porque a concepção social da regulamentação está enraizada. Por exemplo, são legalmente considerados pequenos produtores 
aqueles que obtenham produção diária de até 545 litros, sendo merecedores de atenção especial. Segundo, porque as forças domésticas vinculadas ao leite são relevantes politicamente, ao contrário das pressões externas, já que somente a Nova Zelândia mantém constante pressão para a abertura de mercado para o leite. (Guyomard et al., 1993). A pressão de grupos tem levado o ônus da política de intervenção a recair principalmente sobre as contas do governo (Cardwell, 1996). Ademais, a redução de intervenção tem se dado mais para cereais que para o leite, que deverá continuar a contar com preço mínimo pelo menos até 2006 (Ramsden et. al., 1999).

O Acordo Agrícola, assinado no término da Rodada Uruguai, não foi visto favoravelmente na UE, por agentes que participam do SAG do leite (IATRC, 1997). Isso se deveu à importância do produto para o conjunto dos 15 países. Em 1996 o leite correspondeu a $18 \%$ do valor bruto da produção agrícola da UE, tendo demandado subsídios equivalentes a $60 \%$ do seu valor bruto. (Bouamara \& Réquillart., 1998). Sob esse aspecto, o acordo foi o máximo que a UE poderia conceder e o mínimo aceitável pelos demais países participantes da Rodada Uruguai (Swinbank, 1996).

As medidas preconizadas pelo Acordo Agrícola foram acatadas e implementadas pela UE quanto aos lácteos, mas não impactaram esse setor. A exigência de reduzir preços suporte em $20 \%$ foi implantada e os preços internos ainda continuam elevados. Por outro lado, quanto à restrição à importação, o acordo não modifica em nada o acesso ao mercado de queijos, por exemplo. Quanto aos subsídios à exportação, a UE está autorizada a aumentar o volume exportado com subsídios para manteiga e leite em pó. No caso da manteiga, as exportações têm ficado em torno de 273 mil toneladas/ano. Tomando por base o critério estabelecido no Acordo Agrícola, de redução de $36 \%$ nos subsídios à exportação e de $21 \%$ no volume exportado, a UE pode exportar 366 mil toneladas de manteiga subsidiada por ano, ou $34 \%$ a mais do volume que vem sendo colocado no mercado mundial. 
Dado o peso que a UE tem, como produtora e exportadora de lácteos, uma efetiva liberação do comércio mundial passa necessariamente por uma desregulamentação a ser implementada no âmbito dos países-membros. Não é possível, contudo, prever até quando irá perdurar a política de intervenção nos lácteos aos moldes do que hoje se pratica. Muitos gestores públicos europeus são a favor dessas políticas ou pela substituição de alguns instrumentos, como o preço mínimo, por pagamentos diretos aos produtores. (IATRC, 1997).

\subsubsection{Canadá}

O leite é o terceiro produto agrícola mais importante do Canadá e faturou US $\$ 2,6$ bilhões ou $14 \%$ do PIB agrícola em 1998 . Cerca de $39 \%$ do leite produzido é comercializado na forma fluida. O número de propriedades leiteiras foi de 145 mil em 1971 e de 22,7 mil em 1999, declinando a uma taxa de $4,1 \%$ ao longo da década passada (Cropp, 1999). Por outro lado, o número de vacas por propriedade vem crescendo. Entre 1971 e 1992 a média se elevou de 16 para 34, demonstrando a busca de ganhos de escala (AFPC, 1997). Em 1998 , uma fazenda média contava 50 vacas e faturou $\$ 175$ mil. Quanto ao setor de processamento, o faturamento foi de US $\$ 5,5$ bilhões (Barrichello, 1999).

O SAG do leite canadense é profundamente regulamentado por políticas estaduais e federais. Essas políticas incluem: preço alvo, preço mínimo, sistemas de cotas de produção e subsídios diretos pagos ao produtor. O objetivo é assegurar aos produtores preços internos que permitam a manutenção da qualidade de vida. Para isso torna-se necessário inibir as importações, por meio de barreiras, e assegurar recursos orçamentários que possibilitem transferência de renda para os produtores (Bailey, 1977).

O preço mínimo para o leite é determinado de acordo com o custo de produção. Medidas regulamentatórias são administradas pela Comissão Canadense de Lácteos. Essa agência adquire a oferta excedente e a revende 
no mercado interno, quando há escassez de oferta, ou disponibiliza estoques para o mercado internacional.

O sistema de cotas de produção é definido para cada província e seu estabelecimento reflete a estimativa de consumo doméstico, acrescido da quantidade estimada que deverá ser destinada ao mercado internacional. (AFPC, 1997).

O Acordo Agrícola da Rodada Uruguai foi bem recebido pelos agricultores canadenses, pois poderia viabilizar o aumento nas exportações. A reação dos produtores de leite, contudo, foi de desaprovação. O Canadá promoveu a implantação das medidas estabelecidas no acordo e modificações em termos de regulamentação ocorreram para o leite em 1995, embora se mantenha a base estrutural da política de intervenção voltada para o produto. (AFPC,1997). O mercado doméstico para o leite continuou protegido.

A abertura de mercado considerou o interesse dos produtores e se deu de maneira diferenciada entre os parceiros comerciais. As importações de queijo têm se dado prioritariamente dos EUA, a manteiga da Nova Zelândia e o creme de leite e o leite condensado da Austrália. Mantiveram-se subsídios à exportação de produtos lácteos, embora tenham sido reduzidos.

O Canadá adota a política de discriminação de preços com base em cinco tipos de destino dado ao leite. A produção usada para processamento visando a exportação é remunerada ao preço do mercado internacional. As demais quatro classificações apresentam preços mais elevados, que compensam a perda de receita advinda com os preços do mercado internacional. O gerenciamento desse complexo sistema considera diferentes preços estabelecidos em cada estado, incorporando o uso da matéria-prima, a região produtora e seu destino final: mercado doméstico ou exportação. 
Os produtores são detentores de cotas de produção, que são transacionadas, por apresentarem valor de mercado. Os conflitos entre os agentes são dirimidos em cada estado por agências regionais, que têm o controle e condições de fiscalização do mercado sobre todo o leite comercializado. A coordenação nacional, por seu turno, é feita pelo Comitê Canadense de Gestão da Oferta de Leite e pela Comissão Canadense de Lácteos. (Bailey, 1997).

O estabelecimento do NAFTA (North American Free Trade Agreement) não facilitou a concorrência entre os produtos originários dos EUA e Canadá. Ao contrário, os EUA interpelaram formalmente o Canadá junto a OMC, quanto a adoção de preços diferenciados para o leite a ser destinado ao mercado externo, após processamento. A OMC concluiu que o Canadá cumpriu o Acordo Agrícola, em linhas gerais. Três pontos, contudo, deixaram o leite distante dos pressupostos do livre comércio: o Estado canadense está fortemente envolvido no mercado de lácteos, as exportações continuam a ser fortemente subsidiadas, e o mercado interno é pouco acessível à importações, principalmente para leite fluido. Promover mudança estrutural na intervenção do governo, contudo, é ação de difícil consecução, pois o mercado doméstico para produtos lácteos é muito lucrativo e o peso político dos produtores é compativel com seus elevados lucros. (Larue et al., 1999).

\subsubsection{Austrália}

O Leite é um dos principais sistemas agroindustriais australianos. Compreende $1 \%$ do PIB e $13 \%$ dos produtos alimentares processados. Cerca de $25 \%$ da produção é exportada, o que confere ao país cerca de $10 \%$ de participação do mercado internacional. (Pritchard, 1998).

O setor de leite e derivados tem se estruturado sob regulamentação desde a década de trinta, por se reconhecer que as forças de mercado atuando livremente não levariam a uma situação de atendimento dos interesses dos 
agentes que participam da cadeia produtiva. O Governo Federal regulamenta o leite manufaturado, que corresponde a cerca de $70 \%$ da produção, enquanto os governos de províncias regulamentam o comércio de leite fresco. Essa divisão criou, na prática, múltiplos mercados regionais, e foi responsável pela existência de cooperativas regionais, já que o acesso a outros mercados depende das condições adotadas por cada governo provincial.

Em meados dos anos 80, o Governo australiano garantiu o acesso da Nova Zelândia ao seu mercado, o que iniciou um processo de reestruturação da cadeia produtiva, com redução da intervenção do governo nos preços e na produção. O sistema de preços mínimos passou a contar com a contribuição dos produtores, bem como o subsídio à exportação. A redução da estrutura de intervenção continuou a ocorrer na década seguinte, aumentando o questionamento quanto às barreiras existentes no comércio lácteo entre as diferentes regiões do país. (Bailey, 1997).

A partir de 1995, nova legislação para os lácteos foi introduzida, incorporando os requisitos do Acordo Agrícola. Buscou-se, portanto, mudar a lógica da regulamentação, ao se dar mais relevância a decisões locacionais e à competição, que ao atendimento dos interesses dos produtores quanto ao preço de comercialização. Produtores e indústrias contribuem para um fundo, responsável pelo custeio das despesas de preço mínimo e subsídio à exportação, além de gastos com promoções. Em 1995, por exemplo, somente com promoções foram gastos US $\$ 13,7$ milhões no mercado doméstico e US\$ 5,8 milhões em mercados externos específicos. Mesmo com as mudanças implementadas pós 1995, o mercado lácteo ainda é muito regulamentado e o preço é fixado com base nos custos de produção, processamento e distribuição. (Hill et al., 1999).

A reestruturação do setor lácteo em curso, há quase duas décadas, ao reduzir a participação do Estado, tem levado ao surgimento de quatro novas 
características. Primeiro, tem ocorrido concentração, por meio de fusões e aquisições de cooperativas e empresas. Segundo, alianças estratégicas tem se multiplicado, visando assegurar a participação de produtores e laticínios no mercado, por meio de ganhos de escala, principalmente para produtos de baixo retorno, como manteiga e leite em pó. Terceiro, o sistema de transporte e de distribuição do leite foi reestruturado, ao mesmo tempo que cresceu a importância dos supermercados. Isso tem contribuido para uma maior concentração no processo de distribuição do produto. Quarto, as cooperativas tem operado com baixo nivel de capitalização, o que as tem levado a promover mudanças qualitativas em sua forma de operar. Buscam eficiência e competitividade em suas ações. (Pritchand, 1998).

\subsubsection{Nova Zelândia}

É o grande exportador de derivados lácteos, com pouco subsidio embutido no preço. Isso se deve a dois fatores. Primeiro, o custo de produção é um dos menores do mundo, por utilizarem intensivamente o pastejo rotacionado, o que reduz o uso de concentrados. Segundo, tem uma atuação agressiva quanto a promoção de seus produtos no mercado mundial (Bailey, 1997)

Em 1999 o país contou 13,9 mil produtores de leite, todos vinculados a uma das quatro cooperativas existentes. Cerca de $95 \%$ do leite produzido é exportado, o que coloca esse país muito dependente do mercado internacional. Por outro lado, o setor lácteo é relevante em termos de captação de divisas. Em 1999, o leite respondeu por cerca de $21 \%$ das exportações daquele país.

Em 1994 o setor lácteo, que tinha restrita intervenção do governo, passou por um processo de desregulamentação e foi criada a Comissão de Lácteos da Nova Zelândia, uma entidade privada, de propriedade das cooperativas e que, por força de lei, era a única exportadora. As cooperativas podiam exportar, mas necessitavam de permissão desse Conselho. A visão 
focada no mercado internacional levou à criação da Fonterra, em outubro de 2001. A empresa é resultante da aliança da comissão de Lácteos da Nova Zelãndia, do Grupo Lácteo da Nova Zelândia e da Cooperativa Láctea Kiwi, transformando-se na maior empresa exportadora de lácteos do mundo. Em 2002 a Fonterra e a Nestlé formaram joint-venture visando atuação no continente americano, o que significará a adoção de estratégias de atuação comuns no Brasil, Argentina e Venezuela, inicialmente.

A Nova Zelândia mantém uma rede de distribuição articulada com mais de 80 empresas no exterior e coloca seus produtos permanentemente em mais de 140 países. Além da auto-gestão no comércio internacional, os produtores mantêm o Instituto de Pesquisa Leiteira e o Centro de Excelência Leiteira, entidades que se dedicam à pesquisa e ao treinamento de produtores, bem como ao desenvolvimento de produtos voltados para as características de cada mercado em que atuam. Isso tem assegurado a esse pais uma participação de cerca de $25 \%$ no mercado internacional de lácteos.

Em suma, não houve necessidade de adaptação de política voltada para o setor de lácteos, tendo por base os pressupostos do Acordo Agrícola, dada a condição estrutural de produção, processamento e inserção dos produtos neo-zelandeses no mercado internacional. Por outro lado, este país considerou tímidos os avanços obtidos com o Acordo Agrícola, pois o leite continua sendo um dos setores mais protegidos e um dos mais subsidiados quanto à parcela que os países destinam à exportação, o que reduz a competitividade da Nova Zelândia (Turnbull, 2001).

\subsubsection{Japão}

Como é característica da economia japonesa, o setor lácteo é bastante regulamentado. O país, contudo, converteu procedimentos não tarifários em tarifários no caso de 28 produtos, incluindo leite e derivados. Por apresentar-se como importador líquido de alimentos, a política comercial focou 
as importações, estabelecendo quatro categorias de tarifação, visando delimitar o acesso ao mercado interno. A primeira define tarifas impostas a produtos que podem ser importados pelo setor privado. A segunda estabelece tarifação sobre importação, que deverá se dar diretamente pelo estado. A terceira e quarta classificações se referem, respectivamente, a suínos e arroz.

Os derivados lácteos enquadram-se na segunda categoria. Estão sob o controle estatal, o que inclui também a gestão de estoques necessários para a manutenção da estabilidade dos preços domésticos. Em situações específicas, há autorizações para importação privada, pelo regime de cotas.

A implementação dos requisitos do Acordo Agrícola não foi suficientemente capaz de abrir o mercado japonês para a importação de lácteos. A manutenção das restrições objetivou manter protegida a renda dos produtores. (IATRC, 1997).

\subsection{7 Índia}

Leite é o produto mais importante do setor agrícola daquele país, sendo responsável por cerca de $17 \%$ do valor da produção (Delgado \& Narrot, 2002). Essa importância, contudo, cresceu após a implementação de uma política específica de intervenção voltada para o produto. Ainda nos anos cinquenta e sessenta, a produção manteve-se estagnada e a disponibilidade per capita caiu, com o crescimento populacional.

Nos anos setenta, com a ação do governo, a produção cresceu substancialmente. A primeira ação de intervenção foi no sentido de restringir as importações. Seguiram-se ações no sentido de promover inovações institucionais, visando a redução de riscos para projetos de novas e modernas plantas industriais, bem como a redução de risco para os produtores. $O$ mercado doméstico passou a ser intensamente regulamentado. As exportações e importações foram praticamente banidas e a atividade de processamento 
passou a ser controlada por meio de emissão de licenças de permissão, com prioridade para as cooperativas em relação às empresas privadas.

Tendo como característica principal a pequena produção, esse desenho institucional assegurou aos produtores condições satisfatórias de lucratividade, o que redundou na adesão ao mercado formal de produtores que atuavam na informalidade. Isso contribuiu para assegurar leite de melhor qualidade sanitária à população. Os resultados foram melhores nas regiões em que a intervenção foi mais intensa, pela ação de governos regionais, e onde as cooperativas operavam o mercado (Delgado \& Narrot, 2002). O fato é que a Índia foi galgada à posição de segunda maior produção mundial, sendo responsável por $15 \%$ do total produzido, embora praticamente não participe do comércio mundial de lácteos.

Face às exigências da $\mathrm{OMC}$, derivadas do Acordo Agrícola, a Índia vem promovendo um desmonte de sua política de intervenção. Em 2002 foram extintas as exigências de licenças para processamento lácteo e o mercado encontra-se drasticamente desregulamentado. Ainda no final dos anos noventa foram retiradas as restrições à importação e aquele país passou a participar do mercado internacional como importador de manteiga e leite em pó. Há, no presente, intensa discussão naquele país quanto aos resultados possíveis frente ao novo cenário. Lideranças e técnicos têm levantado a possibilidade de se retornar ao cenário dos anos cinqüenta, com estagnação da produção, e conseqüências econômicas e sociais desfavoráveis.

\subsubsection{América Latina}

A partir da década de 70, o Chile, a Argentina e o Uruguai iniciaram reformas profundas em suas economias. Os demais países latino-americanos adotaram procedimentos nesse sentido a partir da década seguinte. Todos motivados por crises fiscais, traduzidas em elevados índices de endividamento externo e interno, altas taxas de inflação e baixo crescimento da renda nacional. 
A crise fiscal latino-americana levou, portanto, à adoção de programas de austeridade nos gastos do governo, à privatização de serviços, à desregulamentação e, em suma, à uma redefinição do papel do Estado. (IATRC, 1997).

Abandonou-se a estratégia de substituição de importações e caminhou-se para um ambiente de livre mercado. Subsídios, controle de preços e cotas foram eliminados ou reduzidos. As ações do governo ficaram limitadas à promoção e regulamentação de mercados livres e competitivos, e à provisão de bens e serviços onde os mercados mostraram-se falhos.

Em termos de comércio exterior, promoveu-se uma ampla liberalização, com simplificação dos procedimentos legislativos, fim do comércio estatal e redução dos impostos "ad valorem". A maioria dos países fez reformas gerais, não se limitando a setores específicos. Os programas de liberalização foram unilaterais e precederam ao Acordo Agrícola. Os países têm aplicado tarifas aquém do que está permitido pelo Acordo. A abertura econômica ocorreu ditada pelo contexto das reformas econômicas e não em função do término da Rodada Uruguai (De Janvry et al., 1997).

No caso do leite, as políticas macroeconômicas traduziram-se em uma desregulamentação do setor. Em países que não apresentavam autosuficiência, como o Brasil e o México, a abertura econômica atuou como mecanismo auxiliar relevante na redução dos preços dos derivados lácteos para os consumidores, o que impactou favoravelmente o controle dos índices de custo de vida. Por outro lado, em paises exportadores, a adoção da desregulamentação visou facilitar a participação desses países no mercado internacional, com o objetivo de assegurar ingressos contínuos de divisas, como no caso da Argentina e Uruguai, por exemplo. A crise das contas públicas, contudo, não permitiu a implementação de políticas que dessem suporte a ações mais agressivas visando a inserção no mercado internacional. 
Com efeito, as reformas de regulamentação de mercados, implementadas na América Latina, não objetivaram adaptações ao Acordo Agrícola. Iniciadas ainda nos anos 80 , tiveram como motivação a instabilidade econômica do continente. Como o setor agrícola em geral, e o leite em particular, são concebidos por formuladores de políticas como apêndice de políticas macroeconômicas, não houve esforço no sentido prioritário de preservar a renda dos produtores - em países exportadores e importadores. Onde a produção cresceu, isso se deu como consequência e não como objetivo.

Face a mais uma crise de retração de demanda ocorrida em 2001, e valendo-se da condição favorável da moeda nacional frente a moedas internacionais, a Itambé, a Embaré, a Ilpisa, a Confepar, e a Cooperativa Central de Laticínios do Estado de São Paulo criaram em 2002 a trading Serlac, visando o mercado internacional. Foram fechados negócios com países da América Latina, África e China. Por outro lado, também em 2002, representantes privados da Argentina, Brasil, Chile, Uruguai, Austrália e Nova Zelândia criaram a Aliança Láctea Global, com o objetivo de pressionar a OMC para a abertura de mercados na previsível Rodada Doha de negociações. Estes dois fatos demonstram ações no sentido de organizar a participação brasileira no mercado internacional como exportador. Se os resultados obtidos forem favoráveis, poderá caracterizar 2002 como o divisor de águas da atuação brasileira no cenário mundial.

\subsection{Simulações sobre a desregulamentação no mercado de lácteos}

A FAO e a UNCTAD, estimularam que, se todos os países adotassem fielmente os pressupostos do Acordo Agrícola e não implementassem políticas compensatórias para a manutenção da renda dos produtores, como subsídios diretos, os preços dos derivados lácteos no mercado internacional se elevariam em $7,6 \%$ e entre $4,5 \%$ e $7,9 \%$, 
respectivamente, de acordo com modelos de equilibrio geral usados por aqueles órgãos (Sharma et al., 1996).

Nos EUA, se adotado o Acordo Agrícola e eliminado o preço mínimo, o preço doméstico da bebida láctea cairia em $12,8 \%$, da manteiga se elevaria em $5,3 \%$ e os preços dos queijos permaneceriam inalterados. (Wsthoff \& Brown, 1999). Vale lembrar que a adoção dos pressupostos do Acordo Agrícola não extingue todas políticas protecionistas. Caso os EUA adotassem plenamente o livre comércio, contudo, o preço interno do leite fluido cairia $16 \%$ e a receita dos produtores cairia $14 \%$. Com queda de $0,6 \%$ na produção de queijos e aumento no consumo de $2,2 \%$, haveria um aumento no preço de $5 \%$, com redução da oferta de $3 \%$. Os consumidores americanos dispenderiam menos US\$ 648 milhões com produtos lácteos neste cenário. (Cox \& Chavas, 1998).

No caso da UE, Weyeibrock (1998) simulou a redução do preço mínimo e das cotas de importação. Suas conclusões foram que o Acordo Agrícola não afeta a competição nos lácteos. Isso só ocorreria se houvesse uma redução no preço mínimo de $26 \%$ e um aumento no acesso ao mercado interno de $20 \%$. Em ambiente mais competitivo, as exportações lácteas do bloco cairiam $5 \%$ - se eliminada a política de preço mínimo e $26 \%$ - se extintas as cotas de importação.

Valendo-se de um modelo de equilibrio geral, Zhu et. al. (1999) simularam os impactos advindos em cada região com a supressão das principais restrições ao comércio de lácteos. Nesse cenário, todas as tarifas, cotas de importação e subsídios a exportação seriam eliminados, bem como políticas domésticas que poderiam afetar o preço, como cotas de produção e preço mínimo. Seria mantida somente a discriminação de preços em função do uso. 
Sob essas condições, o preço médio para lácteos cairia significativamente para os principais derivados lácteos na Europa Ocidental, Japão, Canadá e México. Nos EUA haveria queda de preços, à exceção da manteiga. Em contrapartida, ocorreria elevação de preços na Europa Oriental, na Austrália, na Nova Zelândia e na América Latina. Em termos mundiais, os preços sofreriam queda de $6,5 \%$ a $8,5 \%$, dependendo do derivado lácteo analisado, conforme Tabela 17.

Tabela 17. Efeitos do livre comércio sobre os preços de derivados lácteos.

\begin{tabular}{lcccc}
\hline & Leite & Queijo & Manteiga & Leite em pó \\
\hline Europa ocidental & $-25,8$ & $-20,4$ & $-37,7$ & $-14,7$ \\
Europa oriental & 25,9 & 19,1 & 34,3 & 20,4 \\
Japão & $-36,4$ & $-13,2$ & $-72,9$ & 5,4 \\
Austrália & 22,5 & 17,1 & 33,0 & 20,4 \\
Nova Zelândia & 50,8 & 33,7 & 63,1 & 26,4 \\
Canadá & $-32,3$ & $-27,2$ & $-44,3$ & $-19,7$ \\
EUA &,- 4 & $-1,5$ & 29,9 & $-14,4$ \\
México & $-17,3$ & $-21,9$ & $-28,8$ & $-18,9$ \\
América do Sul & 17,2 & 19,9 & 12,5 & 10,9 \\
Média mundial & $-7,1$ & $-7,9$ & $-8,5$ & $-6,5$ \\
\hline
\end{tabular}

Fonte: Zhu et al. (1999)

A mudança de preços domésticos nos diferentes países e regiões, e a queda de preços no mercado internacional levaria a modificações em variáveis relevantes (Tabela 18). O consumo cresceria nos países e regiões cujos preços caíssem, enquanto cairia o consumo naqueles em que o inverso fosse registrado. A produção cairia nos países de políticas protecionistas, como é o caso da Europa Ocidental, EUA, Japão e Canadá. Nos países que não adotam políticas de proteção haveria elevação da produção. Seriam os casos da Europa Oriental, Austrália, Nova Zelândia e Mercosul. Em termos mundiais, haveria queda dos excedentes de produção, com o aumento do consumo. 
Sob a ótica orçamentária, haveria ganhos positivos na maioria das contas dos governos. Num balanço final, mesmo com a manutenção de discriminação de preços - instrumento relevante nos EUA, Austrália e Canadá, a retirada de políticas protecionistas levaria a um ganho de bem-estar líquido em todos os paises e regiões simulados. Em termos mundiais, os resultados obtidos foram de US $\$ 2,28$ bilhões.

Tabela 18. Efeitos sobre o bem-estar da liberação do comércio lácteo (US\$ milhões).

\begin{tabular}{lrrrr}
\hline & Consumo & Produção & Contas de Governos & Total \\
\hline Europa ocidental & 12.741 & -14.018 & 2.988 & 1.711 \\
Europa oriental & -6.548 & 6.612 & -62 & 1 \\
Japão & 2.466 & -1.998 & -183 & 285 \\
Austrália & -229 & 357 & 105 & 233 \\
Nova Zelândia & -212 & 750 & 0 & 539 \\
Canadá & 1.096 & -1.038 & 84 & 142 \\
EUA & 126 & -74 & 128 & 180 \\
México & 621 & -405 & -30 & 186 \\
Mercosul & -321 & 333 & 1 & 13 \\
Mundo & 10.337 & -9.966 & 1.909 & 2.280 \\
\hline
\end{tabular}

Fonte: Zhu et al. (1999)

Objetivando estudar o efeito das cotas de produção, Lips \& Rieder (2002) simularam sua extinção e verificaram o seu impacto em diferentes países europeus que adotam essa política, tanto para leite cru quanto para leite processado.

Os resultados apresentados na Tabela 19 demonstram que haveria uma queda generalizada de preços para os dois produtos. Na França, segunda maior exportadora mundial, os preços para leite cru e leite processado cairiam internamente em $20,2 \%$ e $6,5 \%$, respectivamente. Na Holanda, terceira maior exportadora, a queda de preços esperada seria de $19,1 \%$ e $11,8 \%$. Na 
Dinamarca, quinta maior exportadora mundial, seria de $-18,8$ e $-10,1 \%$. Na Alemanha, sexta colocada no ranking de exportação, seria de $-20,1 \%$ e $-6,5 \%$. Apenas com a supressão do regime de cotas, espera-se que os preços e quantidades de leite cru, em termos mundiais, variem em $-0,2 \%$ e $-0,7 \%$, enquanto os preços e quantidades de leite processado em $-0,2 \%$ e $-1,6 \%$.

Tabela 19. Variação percentual de preços e quantidades para leite cru e leite processado, com a retirada de cotas de produção, por países.

\begin{tabular}{lcccc}
\hline \multirow{2}{*}{ Países } & \multicolumn{2}{c}{ Leite Cru } & \multicolumn{2}{c}{ Leite Processado } \\
\cline { 2 - 5 } & Preço (\%) & Quantidade (\%) & Preço (\%) & Quantidade (\%) \\
\hline Alemanha & $-20,2$ & $-0,9$ & $-5,7$ & $-1,4$ \\
Áustria & $-16,8$ & 1,5 & $-6,3$ & 2,0 \\
Bélgica & $-19,7$ & 4,4 & $-8,1$ & 5,5 \\
Dinamarca & $-18,7$ & 6,4 & $-10,1$ & 6,8 \\
Espanha & $-21,0$ & 3,6 & $-11,0$ & 4,4 \\
Finlândia & $-19,0$ & 5,1 & $-12,5$ & 5,3 \\
França & $-20,2$ & 2,0 & $-6,5$ & 1,1 \\
Grécia & $-0,3$ & $-3,0$ & $-0,4$ & $-4,7$ \\
Holanda & $-19,1$ & 14,3 & $-10,6$ & 15,2 \\
Irlanda & $-20,9$ & 16,7 & $-12,5$ & 19,9 \\
Itália & $-19,8$ & 3,3 & $-9,5$ & 3,9 \\
Luxemburgo & $-18,7$ & 13,0 & $-11,8$ & 17,4 \\
Portugal & $-0,1$ & $-2,2$ & $-0,2$ & $-4,8$ \\
Reino Unido & $-30,3$ & 3,5 & $-12,4$ & 4,6 \\
Suécia & $-19,6$ & 2,3 & $-10,3$ & 2,2 \\
Suiça & $-11,3$ & 0,0 & $-6,4$ & $-0,3$ \\
Resto do Mundo & $-0,2$ & $-0,7$ & $-0,2$ & $-1,6$ \\
\hline
\end{tabular}

Fonte: Lips \& Rieder (2002)

\subsection{Considerações finais}

A análise demonstrou que o mercado internacional de lácteos apresenta diferentes tipos de imperfeição, derivada de regulamentação e concentração. O consumo e a produção estão concentrados nos países desenvolvidos e o comércio internacional é concentrado em poucos países. 
A União Européia surge como destaque, dada sua relevância em termos de produção, consumo e, principalmente, pela participação como exportadora. É também, entre os principais paises que formam esse mercado imperfeito, onde se verifica a forma mais complexa de intervenção estatal.

Nos Estados Unidos, na União Européia e no Canadá, a regulamentação visa atender aos interesses dos agentes que compõem a cadeia produtiva, principalmente os produtores. A justificativa para a ação do governo diz respeito a impossibilidade do mercado, por si só, funcionar de maneira competitiva. A ação do governo, todavia, distancia este mercado das condições de Ótimo de Pareto, em vez de aproximá-lo.

Dois casos extremos também merecem destaque em termos de desenhos institucionais. O Japão, por eleger o leite como assunto de controle pleno do Estado, e a Nova Zelândia, pela auto regulamentação do setor.

Como se verificou, as principais economias especializadas em lácteos não foram afetadas pelo Acordo Agrícola. Os mercados domésticos continuam solidamente imperfeitos, o que resulta imperfeição também no mercado internacional. No caso da América Latina, também não ocorreu grandes mudanças institucionais derivadas do Acordo, pois seus pressupostos foram implantadas antes e por motivos macroeconômicos. Austrália e Índia, os únicos exemplos apresentados na análise que sofreram impacto do Acordo, merecem acompanhamento pormenorizado dos desdobramentos que as mudanças deverão gerar. Não se pode afirmar que a desregulamentação de seus mercados levará essas economias a se tornar mais eficientes, pois este procedimento não está ocorrendo de maneira generalizada no mundo.

Há, todavia, perspectivas favoráveis ao mercado de leite. A produção e o consumo mostram-se estabilizados nos países desenvolvidos, enquanto ambos vêm crescendo nos países subdesenvolvidos, mesmo em termos per capita. Adicione-se o fato do consumo ser ainda restrito, o que sinaliza um 
mercado doméstico de largo potencial nesses países. Por outro lado, é cada vez mais intensa a discussão internacional sobre a necessidade de restrição à intervenção estatal no mercado lácteo. A celebração do Acordo Agrícola parece ter legitimado o leite na órbita das negociações comerciais internacionais, em prol da desregulamentação. 


\section{RESULTADO ECONÔMICO DA ATIVIDADE E VISÃO INSTITUCIONAL DOS PRODUTORES}

O capítulo anterior procurou situar o mercado internacional de leite e derivados e as distorções existentes, derivadas de políticas de intervenção de governos, principalmente. Dada a condição brasileira de histórico importador, essas distorções afetam a competitividade e a eficiência do SAG do leite nacional.

Com o propósito de analisar fatores internos que afetariam a competitividade e a eficiência das unidades de produção primária de leite é que o presente capítulo foi concebido. Dessa forma, lançou-se mão do referencial da Economia dos Custos de Transação, pois assume-se que a inserção das propriedades na cadeia produtiva é condicionada por variáveis de mercado, pela forma em que as organizações se estruturam e se relacionam, e pela ação de políticas públicas, que impactam o seu desempenho. A seção 4.1 retrata esse referencial. Na seção 4.2 é apresentada a metodologia utilizada na aferição dos custos de produção, a fonte e o tratamento dos dados. Na seção 4.3 analisam-se as características das propriedades, dos produtores e suas opiniões sobre variáveis que se relacionam diretamente com a competitividade e a eficiência das propriedades amostradas. Na seção 4.4 procurou-se complementar a análise sobre as informações apresentadas nas seções anteriores. 


\subsection{Economia dos custos de transação}

A Economia dos Custos de Transação - ECT coloca-se como instrumento de análise de diferentes formas contratuais, que viabilizam as distintas estruturas de governança desenhadas pelas organizações, para atuarem no mercado de modo eficiente e competitivo. Seu pressuposto é que a firma pode obter todos os insumos necessários no mercado, produzir internamente tudo o que é requerido em seu processo produtivo, ou adotar formas mistas de obtenção de insumos e serviços. Quanto ao produto obtido, a firma pode entregá-lo a outra firma para que as etapas subseqüentes sejam processadas - como transporte, armazenagem, distribuição e venda ao consumidor final, pode assumir o controle de todas estas etapas ou pode assumir algumas delas.

As transações e suas formas de organização são a unidade de análise relevante para a ECT. Para Williamson (1989), a firma é um nexo de contratos e organiza transações necessárias para que ocorra o processo produtivo, em interfaces tecnologicamente separáveis.

Existem pressupostos comportamentais que diretamente interferem nos custos de transação. O primeiro diz respeito à racionalidade dos agentes, limitada pelos custos de se obter e processar todas as informações necessárias à tomada de decisões que levem à maximização de resultados. A impossibilidade de predição de todos os acontecimentos que envolvem uma transação leva ao delineamento de contratos incompletos. As salvaguardas neles contidas materializam este reconhecimento.

O segundo pressuposto refere-se ao oportunismo, pela existência de assimetria de informações entre os agentes. Adicionalmente, as incertezas quanto ao futuro e à busca da realização do auto interesse possibilitam comportamentos oportunistas pelos agentes. 
As transações apresentam atributos como a frequência, a incerteza e a especificidade de ativos, que levam à existência de diferentes estruturas de governança em diferentes transações (Williamson, 1985). Transações discretas tendem a se dar via mercado spot. Na medida em que estas tendem a ser contínuas entre os agentes, torna-se viável, em termos de custo, a adoção de estruturas de governança que viabilizem o levantamento de informações, a confecção de contrato e o monitoramento de seu cumprimento.

O atributo incerteza ocorre pela impossibilidade de se conhecer previamente todos os eventos, bem como pela assimetria de informações entre os agentes (Milgrom \& Roberts, 1992). Níveis diferentes de incerteza, somados à duração das transações, levam a estruturas de governança hierárquica, via mercado ou a estruturas hibridas.

Por seu turno, a especificidade de ativos relaciona-se à decisão de investimento, bem como à perda de valor advinda da reutilização do ativo em outras atividades diferentes daquela para o qual foi planejada. Os custos de transação são diretamente proporcionais à especificidade do ativo, pois quanto mais específico, menor a possibilidade de uso alternativo. $\mathrm{Na}$ ausência de especificidade de ativos, há estímulos a transações via mercado. Na medida em que cresce a especificidade, cresce o estímulo à adoção de estruturas hierárquicas.

Os contratos podem ser classificados em clássicos, neoclássicos e relacionais. Os contratos clássicos são os de natureza discreta e os ajustes ocorrem via mercado. Os contratos neoclássicos referem-se a transações com reflexos no longo prazo e passíveis de demandarem arbitragem. No caso de contratos relacionais, troca-se o esforço de se desenhar um contrato completo, pelo esforço de se manter um sistema negocial e continuado (Macneill, citado por Zilberstajn, 1995) 
Na visão de North (1991:97) "Instituições são restrições criadas pelo homem, que emergem de estruturas políticas, econômicas e da interação social e consistem de restrições informais (sanção, tabus, costumes, tradição e código de conduta) e formais (constituição, leis, direito de propriedade)". As instituições foram criadas ao longo da história para reduzir incertezas.

Em termos econômicos, se todos os agentes têm a mesma função objetivo, as transações ocorrem sem grandes percalços. Mas se há assimetria de informações, os custos de transação são um determinante fundamental para o desempenho econômico. Assim, o papel das instituições é o de reduzir custos de produção e de transação. Instituições políticas e econômicas têm, portanto, a finalidade crítica de reduzir custos, na medida em que minimizam os riscos derivados das situações não previsives.

Para Alston (1998), as instituições determinam o desempenho econômico e este determina as instituições. As instituições são formadas por normas e leis informais e formais da sociedade, que influenciam os tomadores de decisão. Normas informais não dizem respeito a um poder coercitivo do Estado, ao contrário das leis. Como na Figura 6, as normas e leis levam ao direito de propriedade que, juntamente com as normas e a tecnologia, estabelecem os custos de produção e de transação.

Os custos de produção referem-se àqueles necessários à transformação de insumos em produtos e estão diretamente ligados à tecnologia disponível. Incluem custos de coordenação dos fatores de produção usados no processo. A tecnologia afeta o custo de produção na medida em que reduz a necessidade de monitoramento. Já as normas e o direito de propriedade também reduzem custos se, por exemplo, as pessoas têm a cultura de, ao trabalhar intensamente, serão recompensadas pelos seus esforços. 
Custos de transação de trocas incluem os custos associados a negociações e obrigações contratuais. As instituições, nesse caso, podem reduzir o potencial de comportamento oportunista, se suas decisões em relação a possiveis contraditórios entre os agentes são ágeis e se são por eles confiáveis. Se, no limite, não há salvaguardas cobrindo as transações, estas não acontecem.

Dado um conjunto de instituições na sociedade, os agentes tendem a construir contratos entre si para minimizar os custos de produção e de transação, o que resultará num desempenho econômico baseado no sucesso/insucesso que vierem a obter em suas negociações.

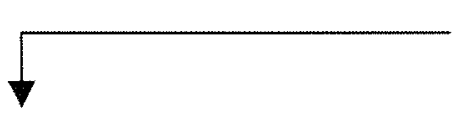

Governo

Instituições Informais

(Normas da Sociedade)

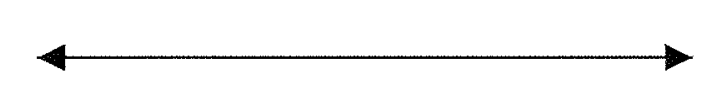

Instituições Formais

(Leis da Sociedade)

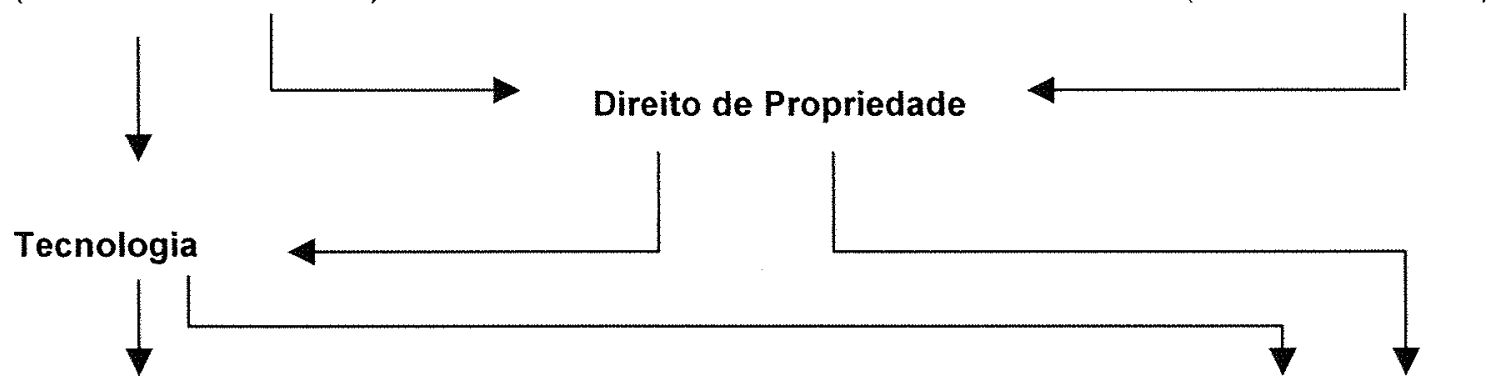

Custos de Produção

Custos de Transação

Desempenho Econômico

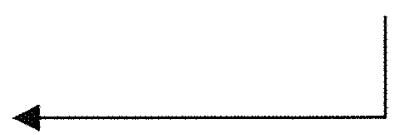

Figura 6 - Instituições e desempenho econômico.

Fonte: Adaptado de Alston (1998)

A Figura 6 explica como as instituições influenciam o desempenho econômico, mas não descreve como ocorrem as mudanças institucionais. Sob 
esse aspecto, Alston (1998) chama a atenção para o fato de estar associada ao desempenho econômico a existência de perdedores e ganhadores (Figura 7). Os perdedores têm incentivos para pressionarem o governo para que promova mudanças institucionais para protegê-los de situações vigentes no mercado. Já os ganhadores têm um incentivo para forçarem o governo a manter o status quo existente ou melhorará-lo ainda mais.

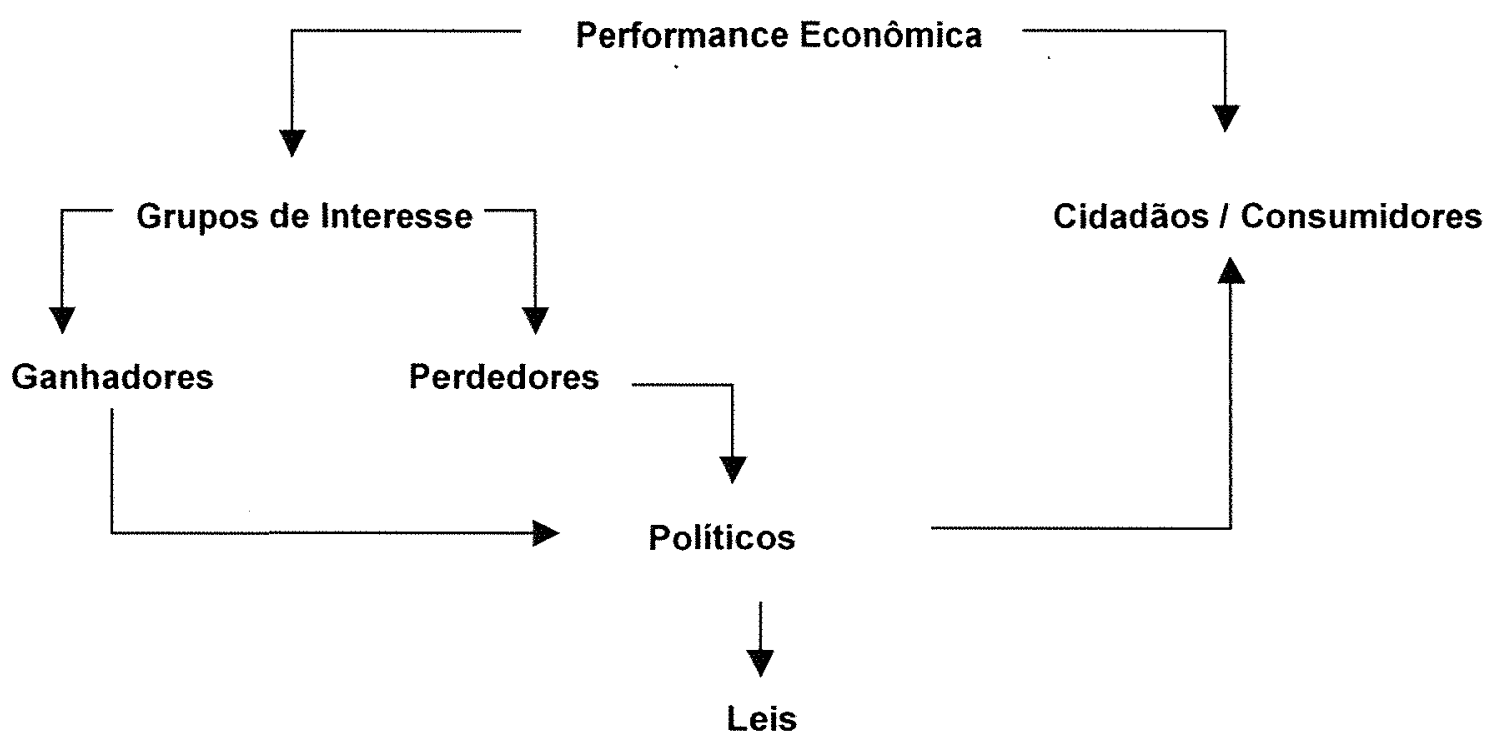

Figura 7 - Determinantes das instituições formais.

Fonte: Alston (1998)

\subsection{Metodologia}

No presente trabalho adotou-se o custo de produção por setores, proposto por Yamaguchi et al. (2001b). Isso se deveu à necessidade de se considerar somente os custos específicos do leite e não da atividade leiteira. Além disso, a abordagem descrita a seguir está em consonância com a teoria tradicional de custos, ao contrário de levantamentos de custos em geral utilizados, que se valem de artifícios contábeis para a obtenção de custos de produção de leite. 
Para a apropriação de custos, cada sistema de produção de leite foi subdivido em quatro setores, sendo dois referentes aos produtos que são obtidos - produção de leite e produção de fêmeas para a reposição do plantel de vacas - e dois que fornecem insumos e serviços para a obtenção dos referidos produtos - produção de alimentos volumosos e prestação de serviços de bens de capital.

A cada um dos setores foram imputados os custos relativos aos ativos específicos - o que inclui custos de capital, além de custos de aquisição de insumos, de serviços e com mão-de-obra. Dessa forma, custos com benfeitorias e instalações, com máquinas motores e equipamentos, custos de depreciação, reparos, juros, energia e custos do fator trabalho (incluindo o autoconsumo), taxas e impostos foram desagregados e atribuídos aos quatro setores, tendo por base a realidade de cada sistema de produção pesquisado.

Custos com o imobilizado em terra, assistência técnica e custos com animais de serviço foram imputados distintamente aos setores produção de leite, produção de fêmeas e produção de alimentos e volumosos. Aquisição de concentrados, sais minerais, sanidade e inseminação artificial, foram arcados pelos setores produção de leite e produção de fêmeas. Custos com capital imobilizado em vacas e em animais de recria foram apropriados respectivamente no setor produção de leite e no setor produção de fêmeas. $\mathrm{O}$ custo do consumo de leite das bezerras foi apropriado ao setor produção de fêmeas, enquanto que a aquisição de mudas, sementes e fertilizantes foi imputada ao setor produção de alimentos volumosos.

Após a apropriação de custos de cada setor, foi necessária uma nova partição, já que produção de alimentos e volumosos e bens de capital são setores meio, pois dão sustentação aos setores produção de leite e produção de fêmeas. A Figura 8 retrata o fluxograma de apropriação de custos. 


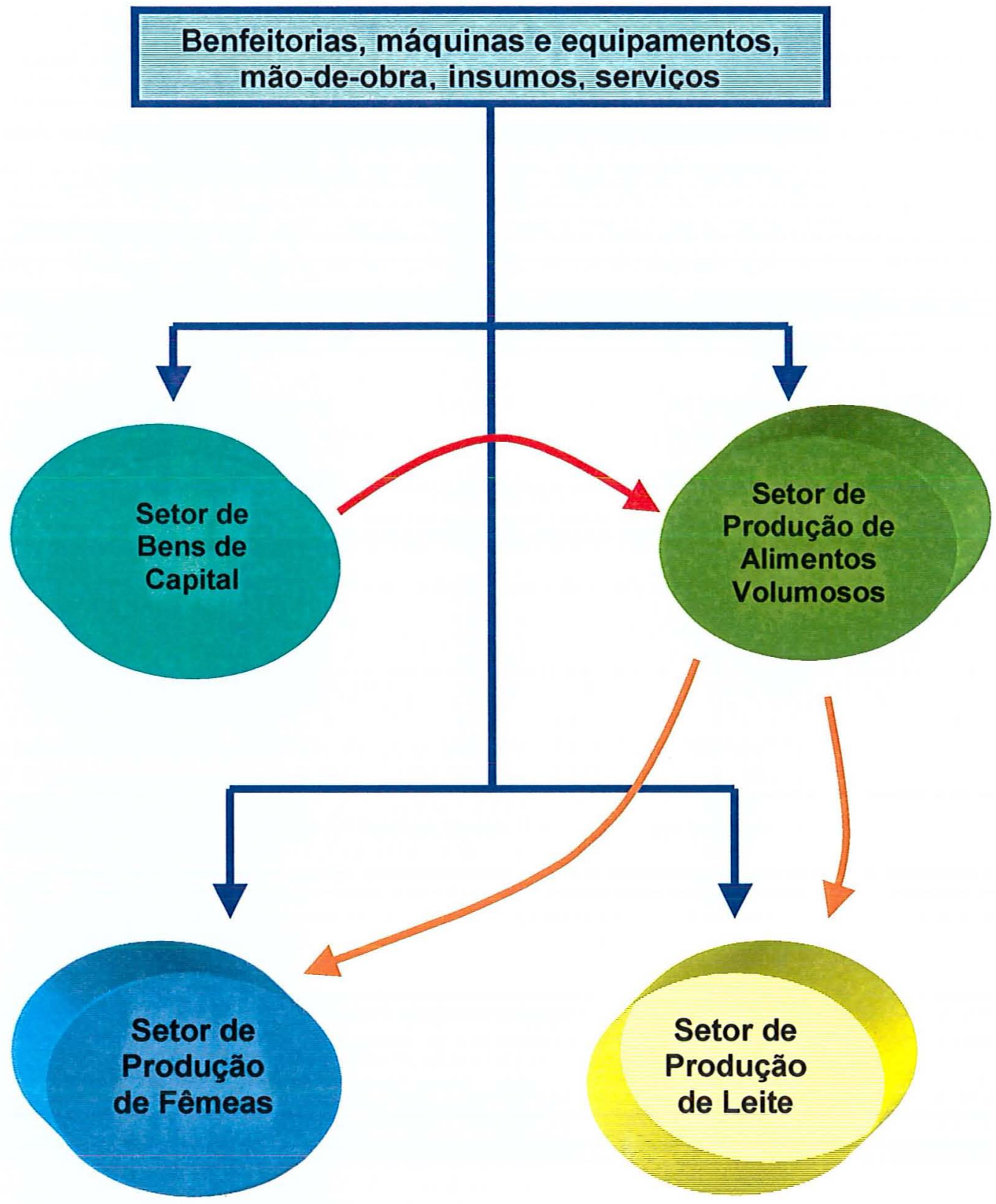

Figura 8 - Fluxograma de apropriação de custos por setores.

Fonte: Elaborado pelo autor 
No presente trabalho foram considerados somente os custos obtidos para o setor produção de leite. Os custos fixos correspondem ao custo do capital imobilizado em benfeitorias e instalações, máquinas, motores e equipamentos e animais de serviço de uso exclusivo ou em comum com demais setores e animais de produção (vacas secas e vacas em lactação). Além disso, são considerados os custos de pastagens próprias, o que inclui depreciações, remunerações e despesas com manutenção (serviços e insumos).

Os custos variáveis consistem de concentrados e sais minerais, alimentos volumosos, mão-de-obra de ordenha, administração e manejo geral, assistência técnica, sanidade, inseminação artificial, energia elétrica, reparos de benfeitorias, instalações e de máquinas, motores e equipamentos, transporte do leite, INSS sobre o valor bruto da produção, cotas de integração do capital e taxas de administração, no caso de cooperativas, e demais gastos.

Em situações em que não foi possivel efetivamente apropriar por setores, com base na realidade observada, optou-se por rateio por Unidade Animal - UA. Foram, contudo, situações restritas, em que esse critério foi aplicado, como gastos com medicamentos curativos. Em vacinas e aplicação de medicamentos ecto e endoparasiticidas, por outro lado, foi possível a apropriação, considerando as práticas de cada propriedade.

O cálculo de depreciações e remunerações do capital imobilizado, considerou o recomendado por Hoffmann (1976), Holanda (1975) e Noronha (1987). A depreciação anual do capital imobilizado em forrageiras, benfeitorias e instalações, máquinas, motores e equipamentos, mobiliários e equipamentos de escritório e animais de produção teve por base o valor inicial e, atribuído pelo proprietário, bem como o tempo de vida útil. $O$ cálculo seguiu a equação

$$
D=\left(V_{i}-V_{f}\right)\left[\frac{r}{(1+r)^{n}-1}\right]
$$


onde:

$V i=$ valor inicial;

$V f=$ valor final;

$r=$ taxa de juros e

$n=$ vida útil.

Para a remuneração pelo uso do fator terra e demais itens de capital imobilizado foi imputada uma taxa anual de $6 \%$ sobre o capital médio imobilizado, segundo a fórmula:

$$
R=\left[\frac{\left(V_{1}+V_{f}\right)}{2}\right] * r
$$

em que, $\mathrm{R}=$ Valor da remuneração anual.

\subsubsection{Fonte de dados e procedimentos adotados}

Promoveu-se inicialmente um pré-teste com o questionário em 14 propriedades vinculadas à Cooperativa de Curvelo-MG.

A definição dos corredores pesquisados considerou dez regiões do Brasil que apresentavam concentração regional de produção, crescimento de produtividade após 1994 e fornecimento para fábricas de leite em pó ou leite UHT (tipo longa vida). Os dados utilizados para esta definição foram do banco de dados econômicos da Embrapa Gado de Leite. A opção pela construção de corredores considerando esses dois produtos deveu-se ao fato de serem transacionáveis, portanto com cotação no mercado internacional, e por serem as duas formas de importação de leite com maior volume no Brasil.

Pelos critérios usados, as 10 regiões selecionadas encontram-se nos 5 maiores estados produtores de leite: Minas Gerais, São Paulo Goiás, Paraná 
e Rio Grande do Sul. Foram contactadas empresas em operação nessas regiões e solicitado que selecionassem 15 propriedades em cada um dos corredores. Na seleção das propriedades, foram considerados os seguintes aspectos:

a) pelo menos $70 \%$ da receita bruta da propriedade proveniente da atividade leiteira;

b) sistemas de produção consolidados ou próximos da consolidação, em termos de rebanho, infra-estrutura, uso de mão-de-obra e outros;

c) referências na produção leiteira, economicamente sustentáveis e com perspectivas de permanecerem no mercado nos próximos cinco anos; e,

d) que apresentassem as características da região em termos de raça, (mestiço ou pura), sistema de produção (a pasto, semiconfinado ou confinado), sistema de alimentação (concentrado ano todo ou somente na seca) e manejo reprodutivo (uso de reprodutores ou inseminação artificial).

O presente estudo não trabalha, portanto, com amostra representativa dos estados pesquisados. Os 10 corredores terminam em São Paulo, capital. Justificativas que fundamentaram esta decisão: primeiro, a maior parte da importação de leite se dá pelo porto de Santos; segundo, o estado de São Paulo concentra o consumo nacional; terceiro, o término dos 10 corredores em um local somente, facilitaria comparações entre corredores. O processamento é realizado próximo ou no município que dá nome ao corredor, excetuando-se Rio Verde, cuja simulação é feita supondo-se venda para processamento em Ribeirão Preto. 
As informações fornecidas referem-se ao período de agosto de 2000 a julho de 2001. Os preços de leite e de insumos, prioritariamente são aqueles constantes nas notas fiscais, fornecidas pelos produtores. As informações relativas à produção, frete e INSS foram fornecidas pelas empresas. Os corredores selecionados são apresentados no Quadro 1.

\begin{tabular}{|c|c|c|}
\hline Estado & Corredor & Município visitado \\
\hline MG & $\begin{array}{l}\text { Ibiá } \\
\text { (Nestlé) } \\
\text { Sete Lagoas } \\
\text { (Itambé) }\end{array}$ & $\begin{array}{l}\text { Araxá, Cachoeira do Prata, Caetanópolis, } \\
\text { Cordisburgo, Curvelo, Esmeraldas, Ibiá, Inhauma, } \\
\text { Iguatama, Luz Maravilhas, Paraopebas, Patrocinio, } \\
\text { Perdizes, Piumhi, Presidente Juscelino, Santana do } \\
\text { Pirapama, Serra do Salitre, Sete Lagoas }\end{array}$ \\
\hline$S P$ & $\begin{array}{l}\text { Jundiaí } \\
\text { (Parmalat) } \\
\text { Ribeirão Preto } \\
\text { (COONAI-Nilza) } \\
\end{array}$ & $\begin{array}{l}\text { Amparo, Brodowsky, Cristais Paulista, Irapuã, } \\
\text { Itirapuã ,Jaboticabal, Jardinópolis, Patrocínio } \\
\text { Paulista, Ribeirão Pret, Santo Antônio da Alegria, } \\
\text { Socorro }\end{array}$ \\
\hline GO & $\begin{array}{l}\text { Piracanjuba } \\
\text { (Centroleite) } \\
\text { Rio Verde } \\
\text { (Centroleite) } \\
\end{array}$ & $\begin{array}{l}\text { Caiapônia, Jataí, Mineiros, Morrinhos, Piracanjuba, } \\
\text { Portelândia, Rio Verde }\end{array}$ \\
\hline$P R$ & $\begin{array}{l}\text { Castro } \\
\text { (Castrolanda) } \\
\text { Mal. Cândido Rondon } \\
\text { (Sudcoop-Frimesa) }\end{array}$ & $\begin{array}{l}\text { Castro, Carambeí, Marechal Candido Rondon, } \\
\text { Entre Rios do Oeste, Matelândia, Medianeira, } \\
\text { Mercedes, Missal, Nova Santa Rosa,Pato Bragato, } \\
\text { Pirai do Sul, Ponta Grossa, Santa Helena, Toledo }\end{array}$ \\
\hline RS & $\begin{array}{l}\text { Teutônia } \\
\text { (Elegê) } \\
\text { Carazinho } \\
\text { (Parmalat) }\end{array}$ & $\begin{array}{l}\text { Almirante Tamandaré do Sul, Arroio do Meio, Água } \\
\text { Santa, Ajuricaba, Carazinho, Chapada, Cruz Alta, } \\
\text { Cruzeiro do Sul, Estrela, Forquetinha, Horizontina, } \\
\text { Humaitá, Ibirubá, ljuí, Júlio de Castilho, Não Me } \\
\text { Toques, Passo Fundo, Pontão, Quinze de } \\
\text { Novembro, Santa Rosa, Sinimbu, Tapera, Teutônia, } \\
\text { Tucunduva, Tuparandi, Selbach, Vera Cruz }\end{array}$ \\
\hline
\end{tabular}

Quadro 1 - Estados, corredores e municípios participantes da pesquisa.

Fonte: Dados da pesquisa

Foram obtidos custos de produção para todas as 150 propriedades pesquisadas. Os valores monetários foram atualizados para novembro de 2001 , tendo por base o Índice Geral de Preços - Disponibilidade Interna, da Fundação Getúlio Vargas/RJ. 
Procederam-se testes de média entre os valores monetários obtidos nos corredores. O teste estatístico escolhido foi o de Tukey, conforme recomendado e descrito em Hoffman (1980). Ao contrário do Teste $t$, o Teste Tukey não exige contrastes ortogonais de médias, nem que a escolha de contrastes se dê previamente. Por este método, testam-se as médias duas a duas. A hipótese testada foi, portanto,

$$
H_{0}: \mu_{i}-\mu_{h}=0
$$

em que $i, h=1,2, \ldots, 10$ e $i \neq h$.

As informações qualitativas relativas aos produtores e propriedades foram obtidas quando da coleta de dados.

\subsection{Análise de resultados entre corredores}

Das 150 propriedades pesquisadas, todas apresentaram custo variável menor ou igual à receita da atividade leiteira, sendo que 26 obtiveram custo total superior à receita. Nos corredores de Minas Gerais (Ibiá e Sete Lagoas) e Teutônia, todas as propriedades demonstraram lucro positivo ou supernormal. No corredor Castro, somente uma propriedade obteve desempenho desfavorável, em Carazinho duas, em Rio Verde três e em Marechal Cândido Rondon quatro. Os corredores de São Paulo (Jundiaí e Ribeirão Preto) apresentaram cinco propriedades com prejuízo cada, enquanto que o corredor Piracanjuba obteve seis propriedades nessas condições.

No Anexo A são apresentados os custos obtidos em cada uma das 150 propriedades, bem como indicadores de eficiência técnica selecionados de propriedades que apresentaram prejuízo, e aqueles obtidos no corredor respectivo, que são médias ponderadas pela produção das propriedades formadoras de cada um dos corredores. 
Esse procedimento visa auxiliar na compreensão do desempenho desfavorável de cada uma das propriedades com lucro negativo. A principal justificativa encontrada diz respeito à baixa produção, que afetou a produtividade de ativos como terra e vacas, bem como onerou o transporte e deprimiu o preço recebido por litro. Das 26 propriedades que apresentaram prejuizo, 23 produziram menos leite que a média do corredor. Há, contudo, casos em que o uso de mão-de-obra e ração por litro produzido foram superiores ao verificado no corredor respectivo, contribuindo para o insucesso de resultado.

O Quadro 2 permite dois tipos de análise: entre propriedades e entre corredores. Em ambas, fica evidente a significativa amplitude de variação das informações apresentadas para variáveis selecionadas. Nos dez corredores, a produção de leite por dia mostrou-se muito variável. Excetuando-se Sete Lagoas, com Coeficiente de Variação (C.V.) de 33\%, os demais corredores tiveram C.V. entre $47 \%$ e $88 \%$. Entre corredores, a produção média diária no corredor Castro foi quatro vezes maior que a obtida no corredor Jundiaí, respectivamente a maior e a menor produção verificada entre os dez pesquisados.

O preço recebido pelos produtores variou pouco entre as propriedades de um mesmo corredor. Teutônia e Rio Verde apresentaram, respectivamente, o menor e o maior C.V. Quanto ao resultado econômico obtido, o C.V. superou a $25 \%$ em todos os corredores, chegando a $69 \%$ em Ribeirão Preto. Castro e Ibiá apresentaram o melhor desempenho, contra os corredores de São Paulo, Mal. Cândido Rondon e Piracanjuba - os piores.

A área destinada à atividade leiteira foi o item com maior variação entre os indicadores selecionados, chegando a apresentar C.V. de $118 \%$ em Teutônia. Numa comparação entre os corredores, Ibiá utilizou 15,7 vezes mais área em relação a Mal. Cândido Rondon, apesar da produção ter sido apenas 
1,7 vezes superior. Quanto ao preço da terra, as maiores variações num mesmo corredor foram encontradas em Piracanjuba e Castro, enquanto que a menor em Mal. Cândido Rondon. Este corredor e Piracanjuba apresentaram, respectivamente, o maior e o menor preço real da terra.

\begin{tabular}{|c|c|c|c|c|c|c|c|c|c|c|}
\hline \multirow[t]{2}{*}{ Itens } & \multicolumn{2}{|c|}{ Goiás } & \multicolumn{2}{|c|}{$\begin{array}{l}\text { Minas } \\
\text { Gerais }\end{array}$} & \multicolumn{2}{|c|}{ São Paulo } & \multicolumn{2}{|c|}{ Paraná } & \multicolumn{2}{|c|}{$\begin{array}{c}\text { Rio Grande } \\
\text { do Sul }\end{array}$} \\
\hline & $\begin{array}{l}\text { Pira- } \\
\text { can- } \\
\text { juba }\end{array}$ & $\begin{array}{c}\text { Rio } \\
\text { Ver- } \\
\text { de }\end{array}$ & Ibiá & $\begin{array}{l}\text { Sete } \\
\text { La- } \\
\text { goas }\end{array}$ & $\begin{array}{l}\text { Jundi } \\
\text {-aí }\end{array}$ & $\begin{array}{l}\text { Rib. } \\
\text { Preto }\end{array}$ & $\begin{array}{c}\text { Cas- } \\
\text { tro }\end{array}$ & $\begin{array}{l}\text { Mal. } \\
\text { Cand } \\
\text { Rond }\end{array}$ & $\begin{array}{l}\text { Teu- } \\
\text { tônia }\end{array}$ & $\begin{array}{l}\text { Cara- } \\
\text { zinho }\end{array}$ \\
\hline Prod.(I.) & 492 & 612 & 846 & 799 & 395 & 749 & 1593 & 508 & 897 & 513 \\
\hline & 50,6 & 46,9 & 55,9 & 33,0 & 70,1 & 53,8 & 88,1 & 53,3 & 77,4 & 86,9 \\
\hline Preço (R\$) & 0,325 & 0,341 & 0,387 & 0,387 & 0,373 & 0,377 & 0,36 & 0,315 & 0,326 & 0,332 \\
\hline C.V. $(\%)$ & 4,9 & 12,3 & 7,0 & 3,9 & 6,4 & 7,2 & 2,5 & 1,9 & 1,2 & 8,4 \\
\hline Lucro (R\$) & 0,035 & 0,045 & 0,095 & 0,069 & 0,031 & 0,03 & 0,092 & 0,032 & 0,074 & 0,052 \\
\hline C.V. $(\%)$ & 48,4 & 40,2 & 31,4 & 35,5 & 45,7 & 68,8 & 35,5 & 38,4 & 24,8 & 35,3 \\
\hline Área (ha) & 101 & 122 & 195 & 168 & 58 & 85 & 29 & 12,4 & 57 & 29 \\
\hline & 96,0 & 51,6 & 77,9 & 79,2 & 89,7 & 100,0 & 75,9 & 84,7 & 117,5 & 72,4 \\
\hline Terra (R\$) & 1206 & 2069 & 1831 & 1742 & 4209 & 3321 & 3741 & 7207 & 5000 & 4493 \\
\hline C.V. $(\%)$ & 55,8 & 32,5 & 49,6 & 46,6 & 38,4 & 34,7 & 57,1 & 26,6 & 36,1 & 40,9 \\
\hline
\end{tabular}

Quadro 2 - Produção diária, preço do leite, resultado econômico, área usada em leite e preço da terra, por corredor, Agosto/2000 a Julho/2001.

Fonte: Dados da pesquisa

Os dados da Tabela 20 demonstram que a variação do preço da terra foi, em média, $600 \%$ e o preço da vaca variou em $72 \%$ entre os corredores. O valor do hectare de terra, medido em litros de leite, mostrou-se diferenciado entre os corredores, mesmo entre aqueles que se localizam no mesmo estado, excetuando-se Minas Gerais. As vacas foram mais valorizadas nos corredores Ribeirão Preto e nos estados do sul do país. 
Tabela 20. Produção, receita e preços de terra e de vaca por corredor, Agosto/2000 a Julho/2001.

\begin{tabular}{|c|c|c|c|c|c|c|}
\hline Corredores & $\begin{array}{l}\text { Produção } \\
\text { (I./dia) }\end{array}$ & $\begin{array}{c}\text { Receita } \\
(R \$ / 1 .)(a)\end{array}$ & $\begin{array}{c}\text { Preço Terra } \\
\text { (R\$/ha) (b) }\end{array}$ & $\begin{array}{l}\text { Preço Vaca } \\
\text { (R\$/cab.) (c) }\end{array}$ & $\begin{array}{l}\text { (b)/(a) } \\
\text { (ha/l.) }\end{array}$ & $\begin{array}{l}\text { (c) / (a) } \\
\text { (l./cab.) }\end{array}$ \\
\hline Piracanjuba & 492 & 0,325 & 1.206 & 860 & 3.711 & 2.646 \\
\hline Rio Verde & 612 & 0,341 & 2.069 & 1.000 & 6.067 & 2.933 \\
\hline Ibiá & 846 & 0,387 & 1.831 & 980 & 4.731 & 2.532 \\
\hline S. Lagoas & 799 & 0,387 & 1.742 & 1.027 & 4.501 & 2.654 \\
\hline Jundiaí & 395 & 0,373 & 4.209 & 837 & 11.284 & 2.244 \\
\hline Rib. Preto & 749 & 0,377 & 3.321 & 1.139 & 8.809 & 3.021 \\
\hline Castro & 1.593 & 0,360 & 3.741 & 1.443 & 10.392 & 4.008 \\
\hline Mal. Rond. & 508 & 0,315 & 7.207 & 1.263 & 22.879 & 4.009 \\
\hline Teutônia & 897 & 0,326 & 5.000 & 1.163 & 15.337 & 3.567 \\
\hline Carazinho & 513 & 0,332 & 4.493 & 1.173 & 13.533 & 3.533 \\
\hline
\end{tabular}

Fonte: Dados da pesquisa

Nos corredores dos estados de São Paulo, Paraná e Rio Grande do Sul, que apresentaram os maiores valores monetários para o fator terra, as propriedades foram de menor tamanho. Considerando-se os preços da terra, do leite e a produção diária por corredor, para se adquirir um hectare de terra eram necessários 45 dias de produção de leite, em Mal. Cândido Rondon, contra menos de seis dias em Ibiá. Aí está um bom exemplo de racionalidade no uso de fatores de produção.

Os dados apresentados na Tabela 21 demonstram uma nítida divisão regional. Com maior intensidade nos estados do Sul que nos estados das regiôes Sudeste e Centro-oeste, encontram-se animais especializados na atividade leiteira e a recomendável prática de aleitamento artificial. $\mathrm{O}$ grau de sangue das vacas nos corredores Jundiaí e estados de Goiás e Minas Gerais caracterizaram-se por maior incidência de sangue holandês e não especializado, enquanto nos corredores do Paraná e do Rio Grande do Sul, ocorreu maior concentração de animais geneticamente puros. Isso explica, em boa parte, o preço mais elevado desses animais na região sul. Já o corredor 
Ribeirão Preto situou-se entre esses dois grupos, encontrando-se, contudo, especialização dos animais de produção. Em relação ao tipo de aleitamento, quase a totalidade das propriedades dos corredores dos estados do sul do país praticava o aleitamento artificial, ao contrário do corredor Jundiaí, que somente utilizava aleitamento natural.

Tabela 21. Grau de sangue das vacas e adoção de aleitamento artificial, por corredor. Agosto/2000 a Julho/2001.

\begin{tabular}{|c|c|c|c|c|c|}
\hline \multirow[t]{2}{*}{ Corredores } & \multicolumn{4}{|c|}{ Grau de Sangue das Vacas } & \multirow{2}{*}{$\begin{array}{c}\text { Aleitamento } \\
\text { Artificial }\end{array}$} \\
\hline & $\begin{array}{c}\text { Puro } \\
\text { Holandês }\end{array}$ & $\begin{array}{c}\text { Mais } \\
\text { Holandês }\end{array}$ & $1 / 2 \mathrm{Hol} . /$ Zebu & Jersey & \\
\hline Piracanjuba & 0 & 09 & 06 & 0 & 03 \\
\hline Rio Verde & 0 & 09 & 06 & 0 & 08 \\
\hline Ibiá & 1 & 07 & 07 & 0 & 09 \\
\hline S. Lagoas & 2 & 08 & 07 & 0 & 09 \\
\hline Jundiaí & 0 & 02 & 13 & 0 & 0 \\
\hline Rib. Preto & 4 & 09 & 02 & 0 & 10 \\
\hline Castro & 11 & 0 & 02 & 2 & 13 \\
\hline Mal. Rond. & 13 & 01 & 0 & 1 & 15 \\
\hline Teutônia & 14 & 01 & 0 & 0 & 15 \\
\hline Carazinho & 15 & 0 & 0 & 0 & 15 \\
\hline
\end{tabular}

Fonte: Dados da pesquisa

Segundo a Tabela 22, o menor e o maior custo de hora-máquina de trator ocorreram respectivamente em Jundiaí e Sete Lagoas. O ponto favorável ao corredor Jundiaí deveu-se à pouca utilização de trator na rotina da propriedade, motivada pelo relevo íngrime das propriedades, e pelo fato de ser, entre os dez corredores, aquele que apresenta maior contratação de serviços de terceiros para trator. Pagam-se, portanto, as horas utilizadas. Nos demais corredores, foi freqüente encontrar esse ativo sub-utilizado. 
Tabela 22. Indicadores de eficiência por corredor, Agosto/2000 a Julho/2001.

\begin{tabular}{|c|c|c|c|c|c|c|c|c|}
\hline \multirow[t]{2}{*}{ Corredores } & \multirow{2}{*}{$\begin{array}{l}\text { Trator } \\
(R \$ / h .)\end{array}$} & \multirow{2}{*}{$\begin{array}{l}\text { Vaca } \\
\text { Lact. } \\
\text { (cab.) }\end{array}$} & \multirow{2}{*}{$\begin{array}{l}\text { V. lac.I } \\
\text { tot.vac. } \\
(\%)\end{array}$} & \multirow{2}{*}{$\begin{array}{l}\text { Taxa } \\
\text { Lotação } \\
\text { (UA/há) }\end{array}$} & \multicolumn{4}{|c|}{ Produtividade } \\
\hline & & & & & $\begin{array}{l}\text { Terra } \\
\text { (I./ha) }\end{array}$ & $\begin{array}{c}M-O \\
\text { (l./d.h.) }\end{array}$ & $\begin{array}{l}\text { Vacas } \\
\text { (I./cab) }\end{array}$ & $\begin{array}{l}\text { Conc. } \\
(1 . / \mathrm{kg})\end{array}$ \\
\hline Piracanjuba & 14,30 & 51 & 74 & 2,94 & 6.004 & 418 & 3.542 & 3,78 \\
\hline Rio Verde & 15,33 & 62 & 72 & 2,08 & 4.904 & 428 & 3.561 & 5,25 \\
\hline Ibiá & 13,07 & 76 & 72 & 1,52 & 4.547 & 448 & 4.423 & 3,71 \\
\hline S. Lagoas & 16,21 & 65 & 75 & 2,21 & 6.870 & 761 & 4.569 & 2,61 \\
\hline Jundiaí & 11,89 & 37 & 61 & 2,70 & 7.242 & 307 & 4.291 & 4,04 \\
\hline Rib. Preto & 13,81 & 46 & 75 & 2,33 & 10.334 & 696 & 6.223 & 3,68 \\
\hline Castro & 14,00 & 70 & 84 & 5,52 & 19.755 & 872 & 7.376 & 3,28 \\
\hline Mal. Rond. & 15,59 & 29 & 83 & 5,53 & 24.564 & 345 & 6.449 & 3,53 \\
\hline Teutônia & 14,72 & 49 & 84 & 3,64 & 16.534 & 469 & 7.018 & 4,18 \\
\hline Carazinho & 15,43 & 26 & 81 & 3,07 & 15.307 & 429 & 6.511 & 3,73 \\
\hline
\end{tabular}

Fonte: Dados da pesquisa

Analisando o percentual de vacas em lactação em relação ao rebanho leiteiro, o corredor Jundiaí apresentou o pior índice de eficiência, seguido dos corredores Ribeirão Preto e dos estados de Goiás e Minas Gerais. Os corredores dos estados do Sul estiveram todos acima de $80 \%$. Em relação à taxa de lotação, o corredor lbiá obteve o pior desempenho, enquanto os corredores do Paraná se destacaram, com os melhores índices. Mesmo tendo como fator limitante o tamanho dos rebanhos leiteiros, Carazinho e Mal. Cândido Rondon demonstraram uso eficiente desse ativo em comparação com os corredores representativos de São Paulo, Minas Gerais e Goiás.

A produtividade da terra foi maior nos corredores dos estados do Paraná e Rio Grande do Sul. Quanto à produtividade da mão-de-obra, os corredores Ribeirão Preto e Castro se destacaram como os de melhores resultados. Os corredores de Jundiaí e Mal. Cândido Rondon, embora guardando suas peculiaridades, apresentam características de uso intensivo de mão-de-obra em relação aos demais fatores, enquanto que a produção nos corredores de Ribeirão Preto e Castro apresentaram perfis de uso intensivo no uso de capital na exploração. 
A produtividade por vaca foi maior em Castro e menor nos corredores do estado de Goiás e em Jundiaí. Em relação à produtividade do concentrado, Sete Lagoas obteve o menor índice, enquanto o corredor Rio Verde obteve o maior.

As propriedades amostradas demonstraram nítida tendência de produção em terras próprias. Somente um caso de produção em terras totalmente arrendadas foi encontrado em 150 observações. $79 \%$ dos produtores utilizaram somente terras próprias e $20 \%$ valeram-se também de arrendamento, conforme Tabela 23.

Tabela 23. Características da posse da terra e do uso de mão-de-obra, por corredor, Agosto/2000 a Julho/2001.

\begin{tabular}{lcccccc}
\hline \multicolumn{1}{c}{ Corredores } & \multicolumn{3}{c}{ Posse da Terra } & \multicolumn{3}{c}{ Uso da Mão-de-Obra } \\
& Própria & Arrendada & Ambas & Familiar & Contratada & Ambas \\
\hline Piracanjuba & 15 & 0 & 0 & 02 & 06 & 07 \\
Rio Verde & 14 & 0 & 01 & 01 & 10 & 04 \\
lbiá & 09 & 0 & 06 & 01 & 08 & 06 \\
S. Lagoas & 12 & 0 & 03 & 03 & 09 & 03 \\
Jundiaí & 11 & 0 & 04 & 04 & 11 & 0 \\
Rib. Preto & 12 & 0 & 03 & 0 & 15 & 0 \\
Castro & 10 & 0 & 05 & 04 & 07 & 04 \\
Mal. Rondon & 13 & 0 & 02 & 08 & 04 & 03 \\
Teutônia & 12 & 0 & 03 & 10 & 01 & 04 \\
Carazinho & 11 & 01 & 03 & 13 & 0 & 02 \\
\hline
\end{tabular}

Fonte: Dados da pesquisa

O uso de mão-de-obra contratada é predominante nos corredores dos estados de Goiás, Minas Gerais e São Paulo, sendo que Ribeirão Preto não utilizou mão-de-obra familiar. Nos corredores dos estados do sul, Castro demonstrou equilíbrio no uso de mão-de-obra familiar e contratada, enquanto os demais corredores valeram-se da mão-de-obra familiar em maior intensidade, principalmente no Rio Grande do Sul. 
Os produtores dos corredores Castro e dos estados de Minas Gerais e São Paulo são aqueles com maior média de idade, enquanto Carazinho, Mal. Cãndido Rondon e Teutônia apresentaram menores médias, (Tabela 24). Já os produtores de Ribeirão Preto são os que apresentaram maior nivel de educação formal, contra Jundiaí, Mal. Cândido Rondon e Carazinho.

Tabela 24. Indicadores sócio-econômicos por corredor, Agosto/2000 a Julho/2001.

\begin{tabular}{|c|c|c|c|c|c|c|c|}
\hline \multirow[t]{2}{*}{ Corredor } & \multirow[t]{2}{*}{ Idade } & \multirow{2}{*}{$\begin{array}{l}\text { Escol. } \\
\text { (anos) }\end{array}$} & \multirow{2}{*}{$\begin{array}{c}\text { Reside } \\
\text { Propried. (unid) }\end{array}$} & \multirow{2}{*}{$\begin{array}{l}\text { Leite é } 100 \% \\
\text { da renda (unid.) }\end{array}$} & \multicolumn{3}{|c|}{ Anos na atividade } \\
\hline & & & & & $\leq 10$ & $11-20$ & $\geq 21$ \\
\hline Piracanjuba & 44,4 & 9,1 & 7 & 9 & 6 & 8 & 1 \\
\hline Rio Verde & 43,4 & 9,1 & 7 & 9 & 9 & 3 & 3 \\
\hline Ibiá & 50,5 & 9,0 & 10 & 7 & 2 & 4 & 9 \\
\hline S. Lagoas & 46,5 & 9,8 & 10 & 13 & 4 & 4 & 7 \\
\hline Jundiaí & 49,6 & 7,5 & 4 & 5 & 3 & 3 & 9 \\
\hline Rib. Preto & 48,7 & 12,4 & 8 & 4 & 5 & 6 & 4 \\
\hline Castro & 46,3 & 9,5 & 11 & 7 & 3 & 5 & 7 \\
\hline Mal. Rond. & 41,1 & 7,5 & 13 & 8 & 4 & 3 & 8 \\
\hline Teutônia & 42,0 & 8,3 & 13 & 4 & 6 & 6 & 3 \\
\hline Carazinho & 40,9 & 7,8 & 13 & 8 & 7 & 6 & 2 \\
\hline
\end{tabular}

Fonte: Dados da pesquisa

Os corredores dos estados do sul e Jundiaí são os que se localizam mais próximos das cidades. Neste corredor, contudo, a menor parcela dos produtores reside na propriedade. Os dados amostrados parecem sinalizar que a distância da propriedade até a cidade não foi fator decisivo na definição do local de moradia. As propriedades de Goiás são as mais distantes das cidades, entre todos os corredores, e a menor parcela reside nas propriedades. Considerando-se que a atividade leiteira é intensiva em administração, e com base nos dados da pesquisa, é de se supor que o local de residência está mais relacionado com o tipo de mão-de-obra empregada. Nos corredores em que predominou a mão-de-obra contratada, o produtor tendeu a residir na cidade. 
Quanto à participação da renda auferida com o leite na composição da renda da propriedade, todas as propriedades obtiveram pelo menos $70 \%$, por critério de definição da amostra. São nos corredores de São Paulo e Teutônia, contudo, que os menores percentuais de propriedades mantêm-se exclusivamente com o leite.

Em termos de tempo de permanência na atividade, cerca de $1 / 3$ iniciou a produção, respectivamente, nos anos setenta, oitenta e noventa. $\mathrm{Na}$ década de noventa, quando ocorreu o início das transformações estruturais no SAG do leite, os corredores de Goiás e Rio Grande do Sul foram os que apresentaram maior percentual de produtores os maiores percentuais de iniciantes na atividade. Os produtores dos corredores dos estados de Minas Gerais, São Paulo e Paraná estão entre aqueles que se iniciaram na atividade nos anos setenta ou menos. Têm, portanto, mais de vinte anos que se dedicam à atividade.

O Quadro 3 retrata os custos, as receitas e os lucros médios por mil litros de leite em cada um dos corredores. Apesar dos corredores do sul apresentarem os maiores preços para terra, foram os que obtiveram os menores custos fixos. Isso se deveu à produtividade da terra e das vacas, bem como à rusticidade e funcionalidade das benfeitorias. O mesmo não se verificou na produtividade de terra e de vacas em Goiás e Jundiaí, bem como no caso singular das benfeitorias, em Ribeirão Preto. 


\begin{tabular}{|c|c|c|c|c|c|c|c|c|c|c|}
\hline \multirow[t]{3}{*}{ Itens } & \multicolumn{10}{|c|}{ Corredores } \\
\hline & \multicolumn{2}{|c|}{ Goiás } & \multicolumn{2}{|c|}{$\begin{array}{l}\text { Minas } \\
\text { Gerias }\end{array}$} & \multicolumn{2}{|c|}{ São Paulo } & \multicolumn{2}{|c|}{ Paraná } & \multicolumn{2}{|c|}{$\begin{array}{c}\text { Rio Grande } \\
\text { do Sul }\end{array}$} \\
\hline & $\begin{array}{l}\text { Pira- } \\
\text { canj. }\end{array}$ & $\begin{array}{l}\text { Rio } \\
\text { Verde }\end{array}$ & Ibiá & $\begin{array}{l}\text { S. La- } \\
\text { goas }\end{array}$ & $\begin{array}{l}\text { Jundi- } \\
\text { aí }\end{array}$ & $\begin{array}{l}\text { Rib. } \\
\text { Preto }\end{array}$ & $\begin{array}{l}\text { Cas- } \\
\text { tro }\end{array}$ & $\begin{array}{l}\text { Mal.C. } \\
\text { Rond. }\end{array}$ & $\begin{array}{l}\text { Teu- } \\
\text { tônia }\end{array}$ & $\begin{array}{l}\text { Cara- } \\
\text { zinho }\end{array}$ \\
\hline C. Fixo & 59 & 50 & 46 & 48 & 62 & 53 & 42 & 39 & 44 & 38 \\
\hline C. Var. & 235 & 221 & 246 & 269 & 272 & 292 & 196 & 239 & 208 & 223 \\
\hline Alimento & 158 & 133 & 176 & 201 & 177 & 214 & 143 & 175 & 153 & 153 \\
\hline Volumoso & 46 & 35 & 50 & 43 & 52 & 75 & 57 & 72 & 64 & 71 \\
\hline Concentr. & 76 & 61 & 101 & 127 & 85 & 105 & 80 & 96 & 85 & 71 \\
\hline Pastagem & 36 & 37 & 25 & 31 & 40 & 7 & 6 & 7 & 4 & 11 \\
\hline M.-de-Ob. & 29 & 30 & 28 & 20 & 34 & 28 & 16 & 22 & 16 & 19 \\
\hline $\mathrm{N}$-qualif. & 22 & 22 & 19 & 15 & 23 & 16 & 10 & 17 & 13 & 15 \\
\hline Enc. Soc. & 6 & 7 & 7 & 4 & 6 & 6 & 3 & 4 & 2 & 2 \\
\hline Qualif. & 1 & 1 & 2 & 1 & 5 & 6 & 3 & 1 & 1 & 2 \\
\hline Transporte & 16 & 19 & 15 & 12 & 19 & 11 & 5 & 14 & 10 & 16 \\
\hline INSS & 7 & 7 & 8 & 8 & 7 & 8 & 8 & 7 & 7 & 7 \\
\hline Outros & 25 & 32 & 18 & 28 & 33 & 31 & 25 & 21 & 22 & 28 \\
\hline C. Total & 294 & 271 & 292 & 317 & 334 & 345 & 239 & 278 & 252 & 261 \\
\hline Receita & 339 & 304 & 386 & 383 & 372 & 374 & 359 & 314 & 319 & 329 \\
\hline Lucro & 45 & 33 & 94 & 66 & 38 & 29 & 120 & 36 & 67 & 68 \\
\hline
\end{tabular}

Quadro 3 - Resultado econômico: custos de produção, preço do leite e lucro por mil litros de leite, por corredor, agosto'2000 a Julho/2001. $(\mathrm{R} \$ 1,00$

Fonte: Dados da pesquisa

Nota: Outros corresponde a custos de reprodução, sanidade, contribuições a sindicatos, associações, pagamentos de INSS, IPVA.

Os custos variáveis foram maiores nos corredores do estado de São Paulo. Em Ribeirão Preto, devido ao custo da alimentação, enquanto em Jundiaí, aos custos de mão-de-obra e alimentação. Em Goiás e na região sul os corredores apresentaram menores custos variáveis.

O custo total foi menor nos estados do Sul, com destaque para Castro, enquanto São Paulo e Sete Lagoas obtiveram os maiores custos de produção. Sob a ótica estatística, os corredores com menores custos foram os quatro do sul. Os resultados do Teste Tukey, ao nível de 5\% encontram-se no Anexo B. 
Os maiores preços ao produtor foram observados nos corredores do estado de Minas Gerais, seguidos pelos corredores do estado de São Paulo e Castro. Os menores preços foram registrados em Mal. Cândido Rondon e nos estados do Rio Grande do Sul e Goiás. Estatisticamente, os estados de São Paulo e Minas Gerais apresentaram preços médios superiores aos demais, enquanto Mal. Cândido Rondon, Teutônia, Piracanjuba e Carazinho apareceram com os menores preços recebidos.

Quanto ao lucro, Ibiá e Castro foram os de melhor desempenho econômico, enquanto Jundiaí, Ribeirão Preto e Mal. Cândido Rondon tiveram desempenho menos favorável. Em termos de análise estatística, Ibiá obteve o melhor resultado, enquanto Jundiaí o resultado menos favorável.

A política de diferenciação de preços recebidos entre os produtores, implementada pelas empresas de laticínios, passou a ser adotada na década passada, depois da desregulamentação do setor. Até o presente, contudo, é possivel encontrar lideranças de produtores que argumentam contra esta prática, principalmente no meio cooperativista. No auge da polêmica, o Conselho Administrativo de Direito Econômico (CADE) foi levado a se pronunciar a respeito, decidindo favoravelmente à discriminação de preços. No levantamento realizado, dos 150 produtores amostrados, $88 \%$ declararam-se favoráveis a adoção dessa política. Vale registrar que $70 \%$ da amostra eram de produtores vinculados a cooperativas, onde a resistência tenderia a ser maior (tabela 25). 
Tabela 25. Opinião dos produtores sobre práticas de preços diferenciados e adoção de contratos formais de comercialização, por corredor.

\begin{tabular}{lcccccccc}
\hline Corredores & \multicolumn{2}{c}{$\begin{array}{c}\text { Preço } \\
\text { Diferenciado }\end{array}$} & \multicolumn{2}{c}{ Volume } & \multicolumn{2}{c}{$\begin{array}{c}\text { Quntrato } \\
\text { Qualidade }\end{array}$} & \multicolumn{2}{c}{ Importância } \\
& Favor & Contra & Sim & Não & Sim & Não & Sim & Não \\
\hline Piracanjuba & 14 & 1 & 11 & 4 & 8 & 7 & 9 & 6 \\
Rio Verde & 14 & 1 & 8 & 7 & 8 & 7 & 8 & 7 \\
lbiá & 13 & 2 & 7 & 8 & 6 & 9 & 6 & 9 \\
S. Lagoas & 11 & 4 & 8 & 7 & 10 & 5 & 8 & 7 \\
Jundiaí & 13 & 2 & 6 & 9 & 8 & 7 & 7 & 8 \\
Rib. Preto & 13 & 2 & 5 & 10 & 8 & 7 & 9 & 6 \\
Castro & 12 & 3 & 5 & 10 & 5 & 10 & 5 & 10 \\
Mal. Rond. & 15 & 0 & 10 & 5 & 10 & 5 & 10 & 5 \\
Teutônia & 13 & 2 & 3 & 12 & 3 & 12 & 10 & 5 \\
Carazinho & 14 & 1 & 6 & 9 & 6 & 9 & 10 & 5 \\
\hline
\end{tabular}

Fonte: Dados da pesquisa

Outro assunto suscita discussão entre lideranças do setor diz respeito à necessidade de se promover a celebração de contratos formais na relação produtor-indústria. Seus defensores argumentam que este procedimento traria garantias ao produtor quanto a preços recebidos, minimizando instabilidades de receita. Outros, como Martins \& Gomes (2000), argumentam que, embora seja tópico relevante, no atual estágio do SAG do leite brasileiro, não existiriam ainda as pré-condições favoráveis à implementação dessa prática, de maneira generalizada, tanto por motivos derivados do ambiente institucional, quanto do ambiente organizacional, com base na categorização apresentada por Zylbersztajn (1996).

Conforme Tabela 25 , dos produtores amostrados, $54 \%$ disseram que não firmariam contrato na presença de cláusula de volume a ser entregue, mesmo que houvesse previsão de sazonalidade de produção ao longo do ano. Em somente quatro corredores, os do estado de Goiás, Mal. Cândido Rondon e Sete Lagoas, a maioria mostrou-se inclinada a aderir a uma cláusula desse tipo. 
Quando perguntados se estariam dispostos a firmarem contrato que estabelecesse um padrão de qualidade, $52 \%$ posicionaram-se negativamente. Os corredores de Goiás, São Paulo, Mal. Cândido Rondon e Sete Lagoas, entretanto, apresentaram maioria favorável a esta cláusula. Convém notar, porém, que não foi apresentado aos entrevistados nenhuma definição de padrão de qualidade, nem se estabeleceu o volume de produção, o que levou os produtores a responderem com base nos seus pressupostos individuais.

Sobre a importância da formalização de contrato entre produtor e a indústria como mecanismo que assegure ao produtor uma perspectiva de receita no período de pelo menos seis meses, $55 \%$ concordaram. Torna-se relevante informar que a coleta de dados se deu sob a influência de uma crise de retração de demanda verificada a partir de julho de 2001, quando algumas empresas se recusaram a receber leite de alguns grupos de produtores, enquanto os demais receberam no pico da entre-safra, preços menores que os obtidos no pico da safra anterior. Em alguma medida, o momento influenciou as respostas dos produtores, pois eles tiveram de frustração de expectativa quanto aos preços.

No levantamento, procurou-se investigar a percepção dos produtores quanto à política de diferenciação de preços. Cada qual com critérios particulares, as empresas vislumbraram nessa sistemática um instrumento de estímulo aos produtores no sentido de se aumentar o volume de produção - o que contribuiria para a redução dos custos de captação, e também para a melhoria da qualidade da matéria-prima captada.

Como toda política de estímulo, para que a mesma seja eficaz, é necessário ser claramente entendida por quem pretende ser estimulado. Por outro lado, considerando-se que os estímulos adotados pelas empresas interferem diretamente no preço recebido pelo produtor, é de se esperar que, 
como interessado, o produtor conheça os critérios adotados e planeje o seu negócio com vistas a obter os melhores preços.

Dos 150 produtores amostrados, $77 \%$ afirmaram que a empresa de laticínios a qual estavam vinculados adotava bonificação por volume de produção, mas não souberam informar o critério - que faixas de estímulos de preço eram consideradas (Quadro 4). Somente no corredor Ribeirão Preto a maioria dos produtores dominava essa informação. Quanto à bonificação por qualidade, $65 \%$ dos produtores também afirmaram que esse item constava na definição do preço recebido por litro de leite, mas desconheciam detalhes. Somente os corredores Ribeirão Preto e Sete Lagoas apresentaram maioria conhecedora da política adotada quanto a esse item. Em relação ao teor de gordura, o percentual de produtores que responderam afirmativamente mas admitiram um certo desconhecimento, foi de $75 \%$ e nenhum corredor apresentou maioria de produtores conhecendo a política de estímulo nesse quesito.

\begin{tabular}{|c|c|c|c|c|c|c|c|c|c|}
\hline \multirow[t]{4}{*}{ Corredores } & \multicolumn{9}{|c|}{ Critérios de Bonificação } \\
\hline & \multicolumn{3}{|c|}{ Volume } & \multicolumn{3}{|c|}{ Quantidade } & \multicolumn{3}{|c|}{ Teor de Gordura } \\
\hline & \multicolumn{2}{|c|}{ Sim } & \multirow[t]{2}{*}{ Não } & \multicolumn{2}{|c|}{ Sim } & \multirow[t]{2}{*}{ Não } & \multicolumn{2}{|c|}{ Sim } & \multirow[t]{2}{*}{ Não } \\
\hline & Sabe & $\begin{array}{l}\text { Não } \\
\text { Sabe }\end{array}$ & & Sabe & $\begin{array}{l}\text { Não } \\
\text { Sabe }\end{array}$ & & Sabe & $\begin{array}{l}\text { Não } \\
\text { Sabe }\end{array}$ & \\
\hline Piracanjuba & 0 & 15 & 0 & 2 & 12 & 1 & 2 & 13 & 0 \\
\hline Rio Verde & 2 & 13 & 0 & 4 & 10 & 1 & 2 & 11 & 2 \\
\hline Ibiá & 5 & 10 & 0 & 2 & 13 & 0 & 2 & 13 & 0 \\
\hline S. Lagoas & 2 & 13 & 0 & 8 & 6 & 1 & 1 & 14 & 0 \\
\hline Jundiaí & 2 & 13 & 0 & 7 & 5 & 3 & 2 & 8 & 5 \\
\hline Rib. Preto & 9 & 6 & 0 & 8 & 6 & 1 & 7 & 7 & 1 \\
\hline Castro & 3 & 10 & 2 & 4 & 9 & 2 & 4 & 11 & 0 \\
\hline Mal. Rond. & 5 & 10 & 0 & 5 & 10 & 0 & 5 & 10 & 0 \\
\hline Teutônia & 3 & 12 & 0 & 2 & 13 & 0 & 4 & 11 & 0 \\
\hline Carazinho & 2 & 13 & 0 & 2 & 13 & 0 & 2 & 13 & 0 \\
\hline
\end{tabular}

Quadro 4 - Conhecimento, pelos produtores, de critérios de bonificação adotados e suas preferências, por corredor.

Fonte: Dados da pesquisa 
Quanto ao critério gostariam que fosse mais valorizado, $57 \%$ afirmaram qualidade, contra $42 \%$, que preferiram volume de produção. A maioria dos produtores em seis corredores optou por qualidade (tabela 26).

Tabela 26. Preferência de produtores quanto ao critério de bonificação a ser valorizado, por corredor.

\begin{tabular}{lccc}
\hline Corredores & Volume & $\begin{array}{c}\text { Preferência } \\
\text { Quantidade }\end{array}$ & Teor de Gordura \\
\hline Piracanjuba & 8 & 7 & 0 \\
Rio Verde & 4 & 11 & 0 \\
lbiá & 10 & 5 & 0 \\
Sete Lagoas & 7 & 7 & 1 \\
Jundiaí & 2 & 13 & 0 \\
Ribeirão Preto & 2 & 13 & 0 \\
Castro & 6 & 9 & 0 \\
Mal. Cândido Rondon & 5 & 10 & 0 \\
Teutônia & 7 & 8 & 0 \\
Carazinho & 12 & 3 & 0 \\
\hline
\end{tabular}

Fonte: Dados da pesquisa

Pelo elevado valor da terra, por terem as menores propriedades, rebanho especializado e por disporem de manejo com práticas importantes na manutenção de higiene, mas ainda de modo não generalizado, era de se esperar que os produtores inseridos em corredores do sul, majoritariamente optassem pelo critério qualidade. Carazinho colocou-se como exceção, contudo. Isso pode ter ocorrido em função da coleta de dados ter ocorrido exatamente no momento em que a Parmalat implantava um novo e detalhado esquema de bonificação por qualidade, com ampla pontuação em diferentes práticas. O natural receio a mudanças e a restrita familiaridade com os novos procedimentos e seus efetivos retornos, apesar do esforço de divulgação, podem ter incorporado algum tipo de viés nas respostas. 
A maioria dos produtores do corredor Jundiaí optou pelo critério qualidade, apesar de ser o corredor com tecnologia menos especializada na produção de leite. Supõe-se que os produtores vislumbram restrições ao aumento da produção via incorporação de novas terras, dado o elevado valor que esse fator representa na região. Ademais, as propriedades são de tamanho restrito e com topografia bastante acidentada, o que dificulta a produção de alimentos para o rebanho leiteiro. O aumento da produção poderia ocorrer, nesse caso, com a maior especialização do rebanho. A julgar, contudo, pelas declarações expontâneas dos produtores durante a coleta de dados (favoráveis à rusticidade do rebanho), não Ihes restaria outra opção senão o critério qualidade, até pela subjetividade deste conceito para os produtores.

O capítulo anterior discutiu a característica de ser o leite, em todo o mundo, assunto tipicamente de Estado. Com efeito, para fazer valer os seus interesses dos produtores, torna-se necessário organizá-los em grupos de pressão. No Brasil, a mobilização de produtores visando reinvidicar decisões favoráveis aos produtores tem se dado, principalmente, pela Confederação Nacional da Agricultura - CNA e algumas federações estaduais. Na base dessas instituições estão os sindicatos de produtores. Portanto, é de se supor que, quanto mais produtores sindicalizados existirem, mais forte será o poder de pressão. Além disso, quanto melhor informado sobre decisões de governo que afetam a atividade, mais sólida será a participação dos produtores nos organismos que os representam.

$\mathrm{Na}$ amostragem realizada, somente $56 \%$ dos produtores eram sindicalizados (Figura 9). Os corredores do Paraná apresentaram uma minoria de produtores com vínculo sindical. Aqueles corredores são estruturados em cooperativas, que em alguma medida poderiam substituir o sindicato no imaginário dos produtores. Os demais corredores formados por cooperativas, contudo, tiveram a maioria dos produtores sindicalizados: Teutônia, Ribeirão Preto, Sete Lagoas e os de Goiás. Neste estado, mais de 3/4 dos produtores 
participantes da amostra são sindicalizados. Por outro lado, excetuando-se o Paraná, $2 / 3$ dos produtores cooperados são sindicalizados, contra $56 \%$ dos produtores que fornecem leite para terceiros.

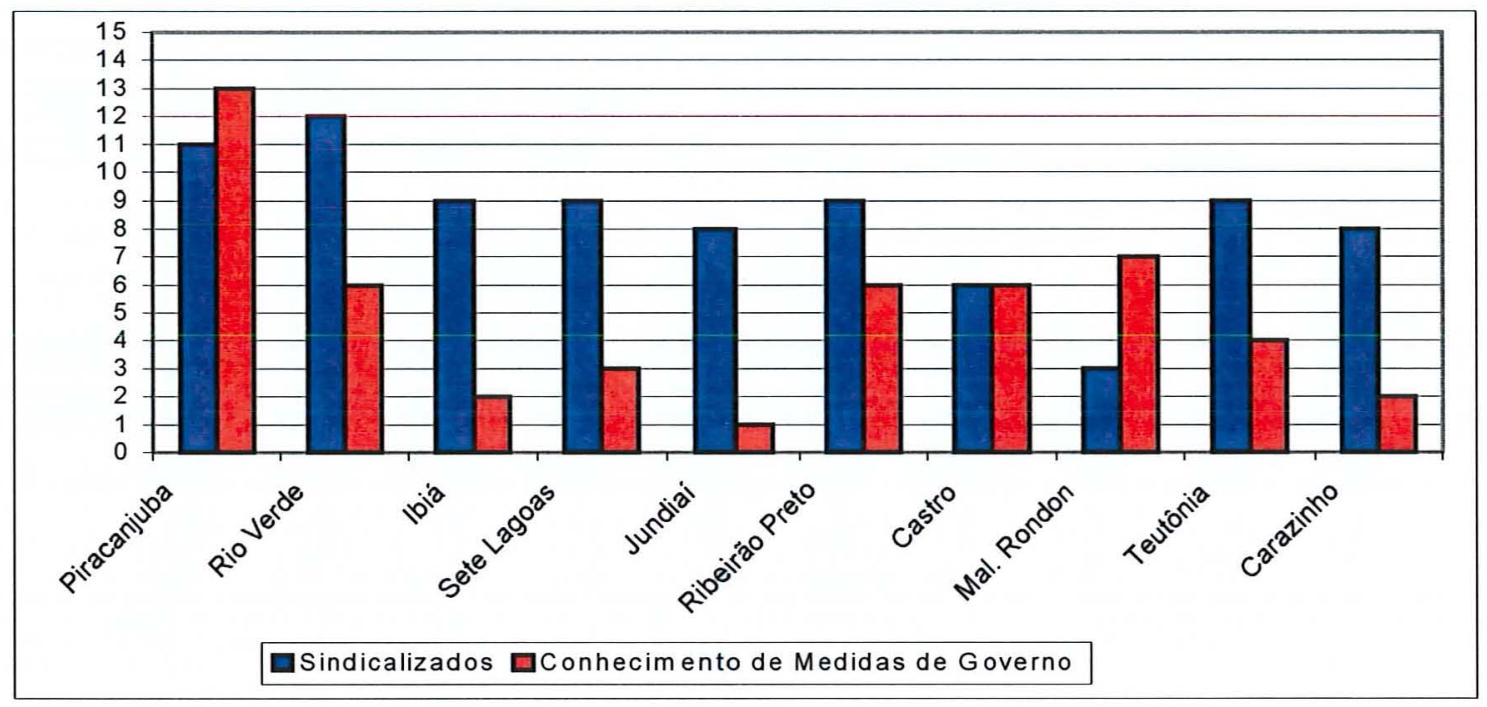

Figura 9 - Produtores sindicalizados e conhecimento de medidas adotadas pelo Governo que afetaram o SAG do leite, por corredor.

Fonte: Dados da pesquisa

Em relação a medidas tomadas pelo governo nos 24 meses que antecederam à pesquisa e que diziam respeito ao SAG do leite, os produtores mostraram pouco conhecimento. Somente $1 / 3$ se manifestou à respeito, em que pese medidas de impacto terem ocorrido, como as salvaguardas anti-dumping, linha de créditos direcionados ao leite (Pró-leite) e a nova legislação sanitária então em discussão, todas com amplo envolvimento de lideranças dos produtores, além de medidas de âmbito estadual, como a redução de ICMS incidente nos derivados lácteos ocorrido no Paraná, por exemplo. Dos 
produtores cooperados, $43 \%$ mostraram-se atualizados, contra $11 \%$ daqueles que são fornecedores de terceiros.

Quanto à instituição que representaria os seus interesses, de maneira expontânea e respostas múltiplas, 56 produtores afirmaram ser 0 sindicato, 50 nenhuma instituição, 34 as cooperativas/laticínios, 27 a CNA, 14 o Poder Executivo, 12 a Leite Brasil e 8 o Poder Legislativo (Figura 10).

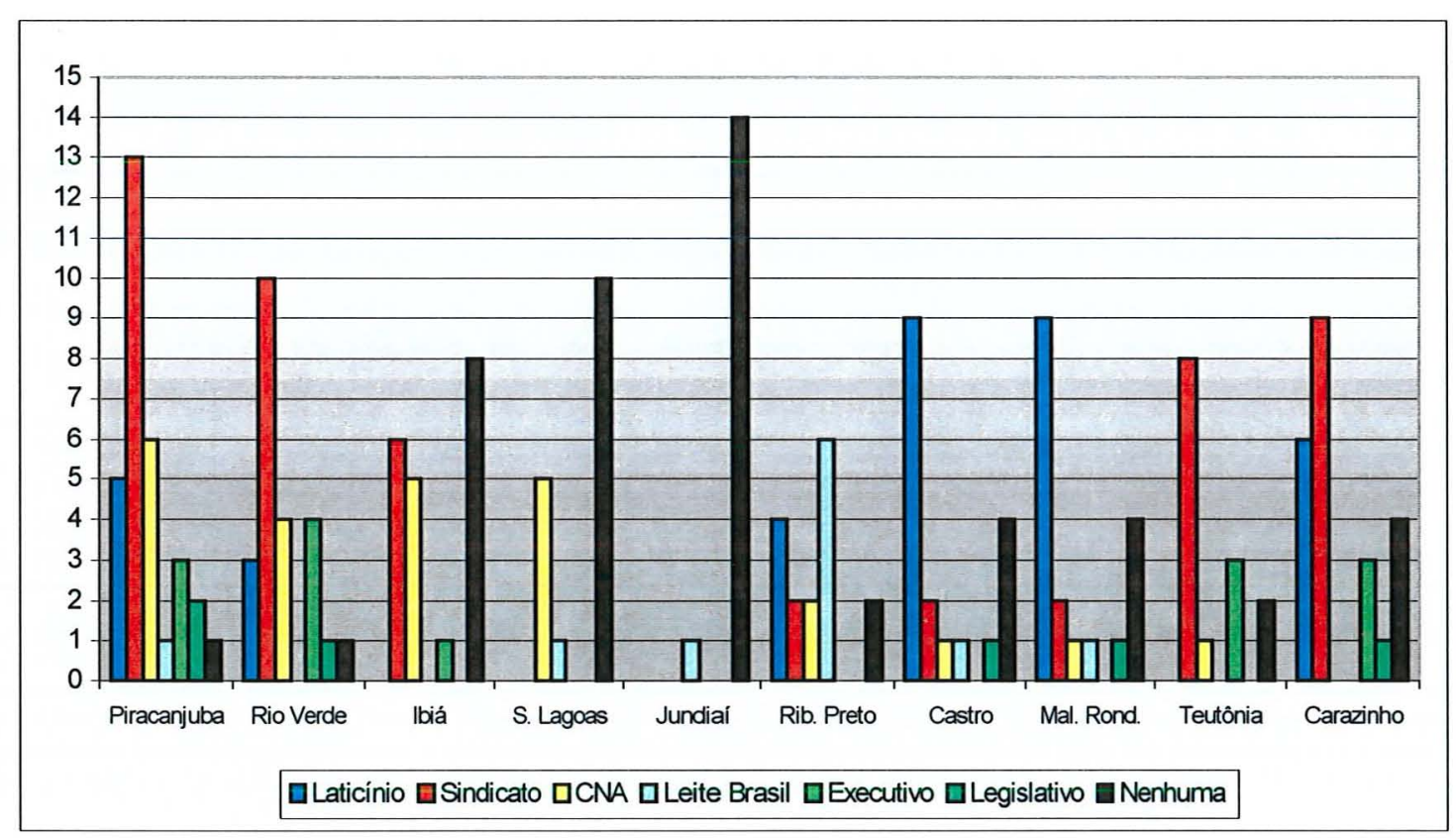

Figura 10 - Instituições que representam os interesses dos produtores. Respostas expontâneas e múltiplas.

Fonte: Dados da pesquisa

Considerando-se que $1 / 3$ dos produtores afirmaram desacreditar em quaisquer instituições, daqueles que acreditavam em pelo menos uma, os sindicatos rurais surgem com importância significativa, seguido das cooperativas/laticínios e da CNA, na visão dos produtores, quanto à defesa de seus interesses. 
Os corredores de Goiás foram os que mais citaram os sindicatos, sendo também aqueles com maior taxa de produtores sindicalizados, seguidos dos corredores do Rio Grande do Sul. Por outro lado, nos corredores de Minas Gerais e Jundiaí os produtores mostraram-se mais desacreditados quanto a atuação das instituições e responderam, majoritariamente, que nenhuma instituição cumpre o papel de representá-los. Sob este aspecto, Minas Gerais apresentou resultados surpreendentes, dado o intenso envolvimento da federação estadual da agricultura com o leite. A CNA foi mais lembrada nos corredores dos estados de Goiás e Minas Gerais, enquanto que a Leite Brasil no corredor Ribeirão Preto. Nesse corredor, os produtores inclusive contribuem mensalmente para esta Associação. Já a cooperativa foi mais freqüentemente citada no Paraná, o que indica que, naqueles corredores, a cooperativa tem também a função de representar os produtores.

Os produtores foram estimulados a avaliar o desempenho de instituições na defesa dos interesses dos produtores de leite. Objetivava-se, dessa forma, não somente conhecer a opinião, mas também verificar o nivel de conhecimento que os produtores detinham em relação às instituições. Os resultados obtidos para a CNA constam da Figura 11. Dos entrevistados, $62 \%$ afirmaram não conhecê-la ou não conhecer o trabalho que realiza em relação aos produtores de leite. Somente nos corredores Rio Verde e Sete Lagoas a maioria afirmou conhecê-la. Nos corredores Jundiaí e estados do sul concentrou-se o maior percentual de desconhecimento. Nesses corredores, apenas um em cada quatro produtores a reconheceram ou reconheceram o seu trabalho. 


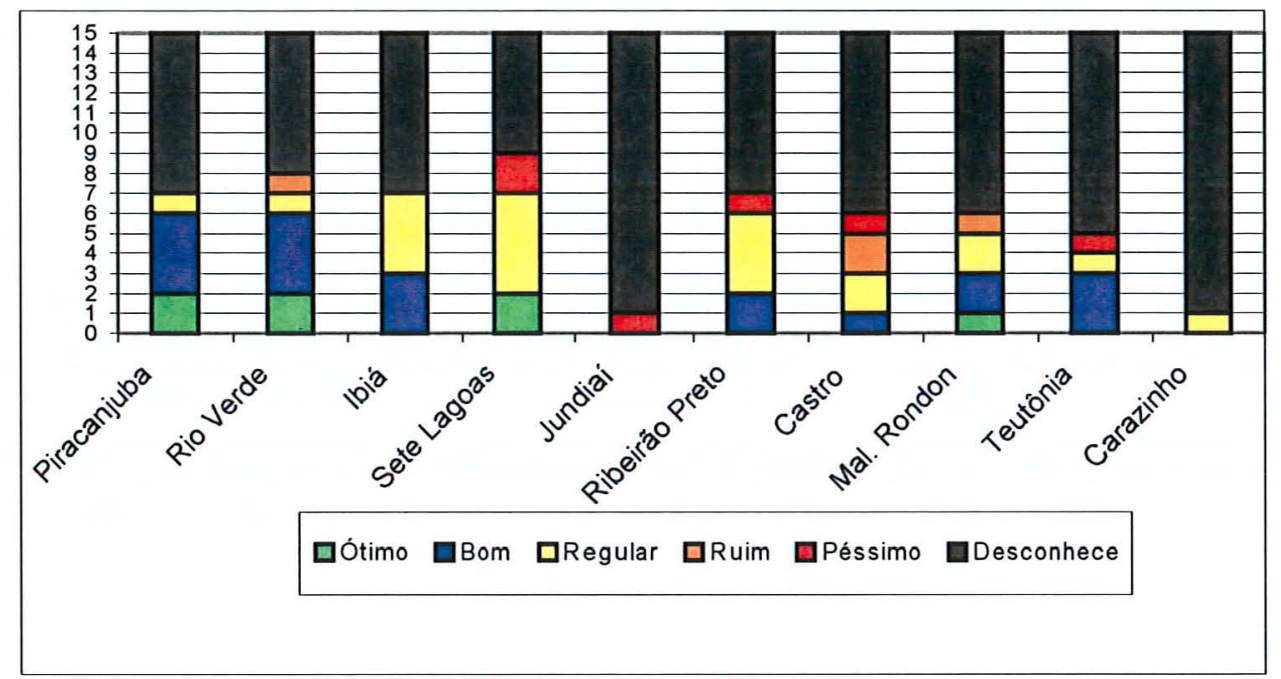

Figura 11 - Opinião sobre o trabalho desenvolvido pela CNA na defesa dos interesses dos produtores, por corredor.

Fonte: Dados da pesquisa

Considerando-se apenas os produtores que afirmaram conhecer a CNA, 45\% avaliaram-na positivamente (ótimo e bom), enquanto $16 \%$ de maneira negativa (ruim e péssimo), o que resulta numa avaliação positiva de $29 \%$. Os corredores de Goiás, Ibiá e Teutônia foram os que esta Instituição obteve melhor avaliação.

Juntamente com a CNA, a Leite Brasil tem cumprido relevante papel no sentido de defender os interesses dos produtores. Dos produtores amostrados, contudo, $68 \%$ afirmaram não conhecê-la. Os dados apresentados na Figura 12 demonstram que a quase totalidade dos produtores dos corredores Rio Verde, Jundiaí e Carazinho a desconhecem. Somente no corredor Ribeirão Preto a maioria a reconhece. Nesse corredor; todavia, esperava-se que todos os produtores a conhecessem, pois todos os produtores analisados faziam contribuições mensais para a Associação, por meio de 
desconto automático processado pela Coonai, especificado nas notas fiscais em poder dos produtores. Dos que a reconhecem, a avaliação é positiva (17\%).

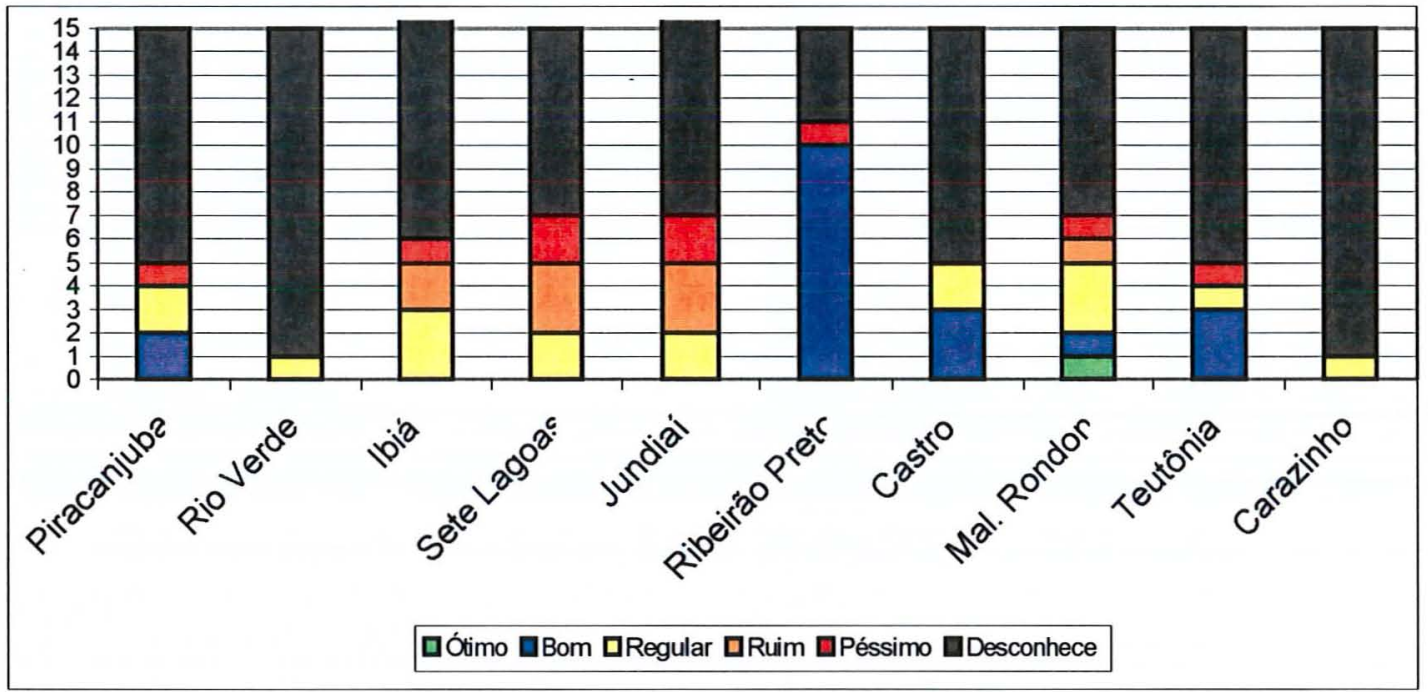

Figura 12 - Opinião sobre o trabalho desenvolvido pela Leite Brasil na defesa dos interesses dos produtores, por corredor.

Fonte: Dados da pesquisa

Os produtores analisaram o comportamento da indústria de laticínios e não especificamente a empresa a que estavam vinculados, em termos de defesa de seus interesses. Embora os interesses de produtor e indústria sejam diferentes objetivou-se, com essa pergunta, verificar o "animus" dessa relação na visão dos produtores, pois na busca de maior competitividade do SAG, torna-se necessário estabelecer a coordenação da cadeia produtiva, sendo saudável que sejam os conflitos reduzidos entre os elos que a compõem.

O comportamento da indústria de laticínios foi reprovado pelos produtores amostrados (Figura 13). Treze por cento consideraram-na favorável na defesa de seus interesses, enquanto $54 \%$ entenderam desfavoráveis suas 
ações em relação a esse item, o que traduziu numa avaliação negativa de $41 \%$ de todos os produtores. Os cooperados foram mais críticos que os produtores vinculados a empresas. Enquanto que no primeiro a indústria apresentou avaliação negativa de $47 \%$, no segundo a avaliação, também negativa, foi de $29 \%$.

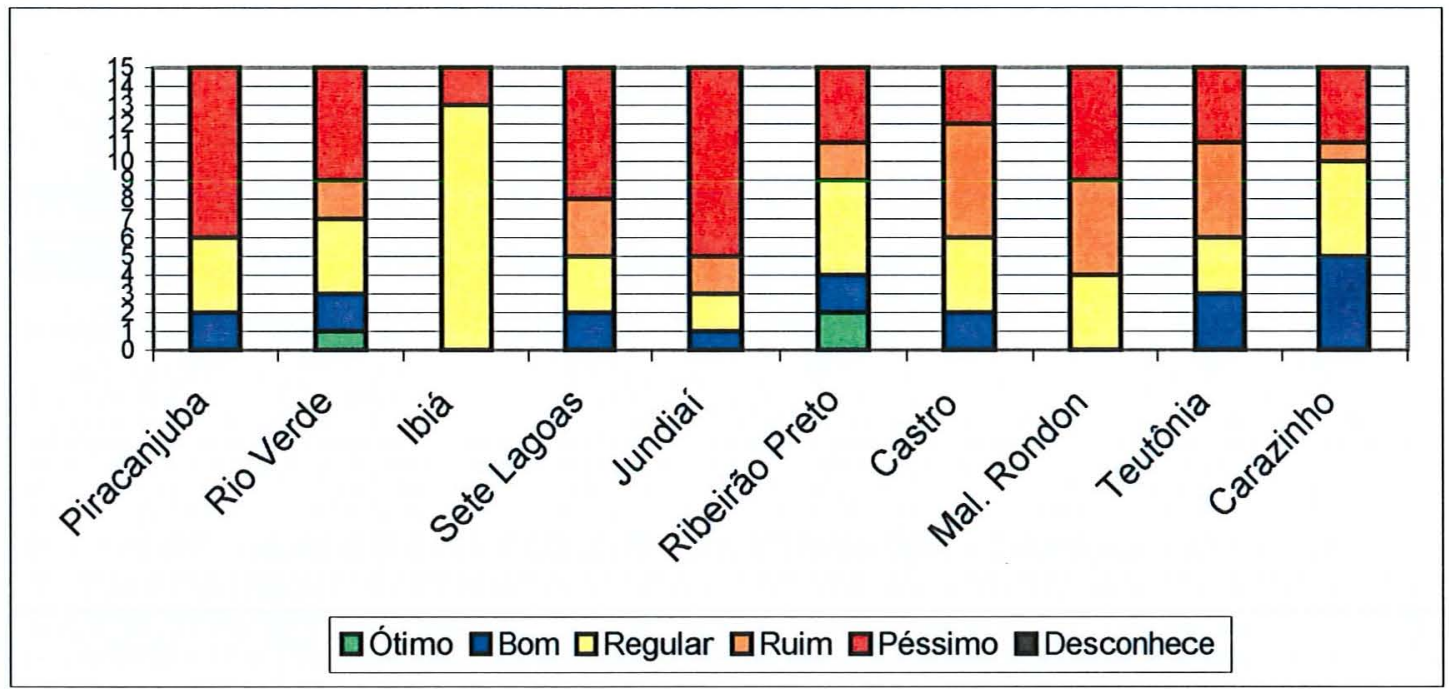

Figura 13 - Opinião sobre o trabalho desenvolvido pela Indústria de Laticínios na defesa dos interesses dos produtores, por corredor.

Fonte: Dados da pesquisa

Dadas as tradições brasileiras, consubstanciadas no regime presidencialista, o poder Executivo tem amplas condições de formular e implementar políticas setoriais. Na visão dos produtores, a avaliação da atuação desse poder em relação a medidas que atendam aos seus interesses foi amplamente rejeitada por $78 \%$ dos entrevistados, não se especificando as distintas esferas (federal, estaduais e municipais). De acordo com a Figura 14, os corredores mais críticos foram Sete Lagoas e Jundiaí, que apresentaram 
avaliação negativa de $87 \%$ e $73 \%$, respectivamente. Foram também os que mostraram maior descrédito nas instituições em termos de defesa de seus interesses. Os corredores que fizeram menores avaliações negativas foram Rio Verde e Ribeirão Preto, com $-13 \%$ e $-27 \%$, respectivamente. Em termos de estados, Goiás apresentou média de avaliação para o Poder Executivo de $26 \%$, seguido de São Paulo, com $-50 \%$. Os demais estados avaliaram com $60 \%$ ou ainda menos.

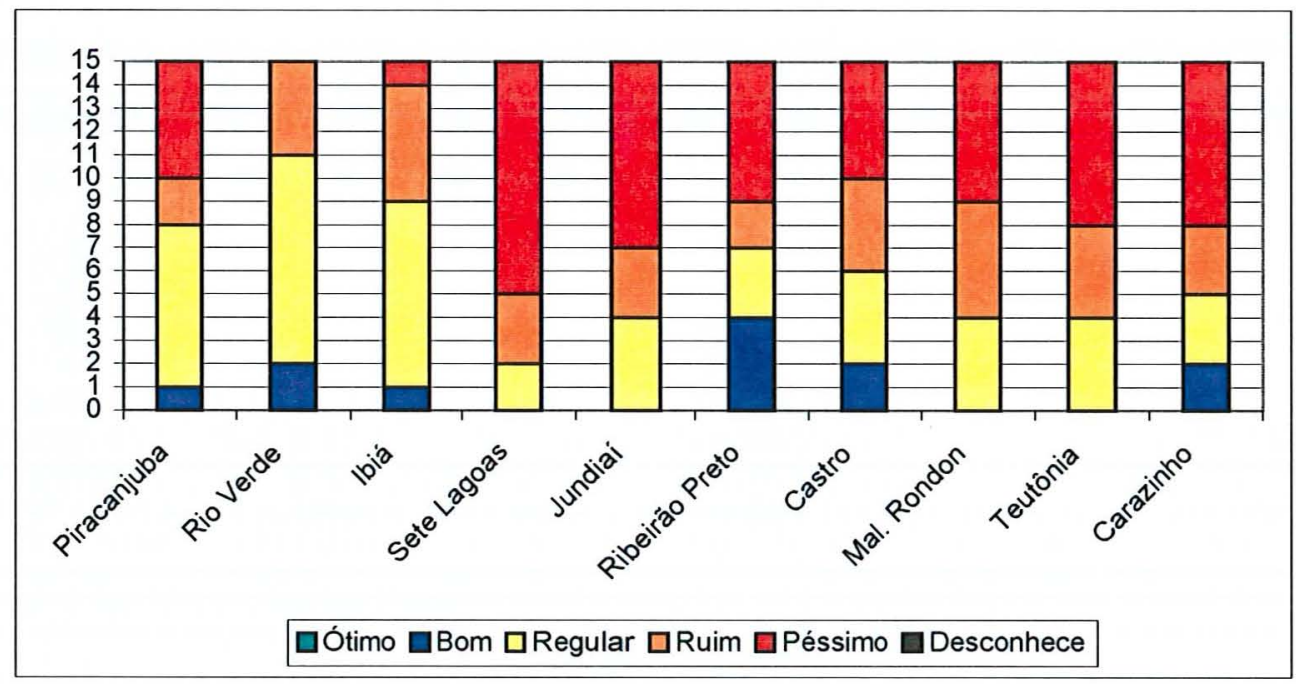

Figura 14 - Opinião sobre o trabalho desenvolvido pelo Poder Executivo na defesa dos interesses dos produtores, por corredor.

Fonte: Dados da pesquisa

O Poder Legislativo foi a instituição com a pior avaliação. No conjunto de todos os produtores, obteve avaliação negativa de $75 \%$, conforme dados extraídos da Figura 15. Os corredores Jundiaí.e Carazinho avaliaram-no com $-100 \%$. Entre os estados, a avaliação menos negativa se deu nos 
corredores de Goiás, com média de $-47 \%$, seguido do Paraná, com média de $60 \%$. Nos demais estados a avaliação esteve acima de $-87 \%$.

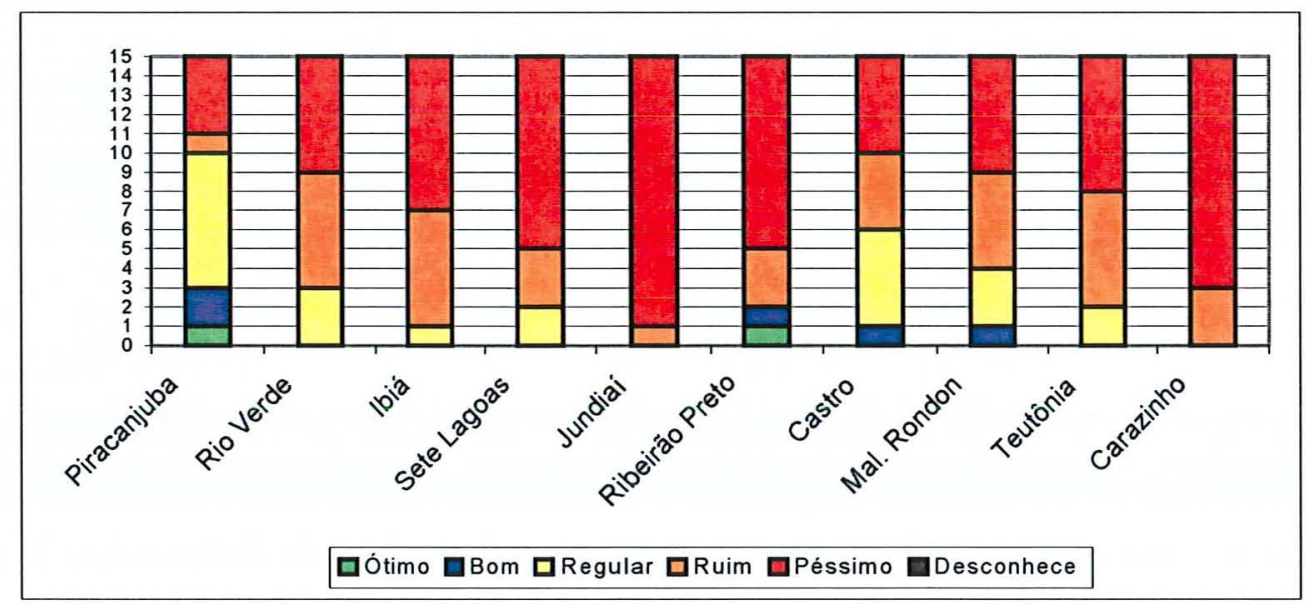

Figura 15 - Opinião sobre 0 trabalho desenvolvido pelo Poder Legislativo na defesa dos interesses dos produtores, por corredor.

Fonte: Dados da pesquisa

As Figuras 16 e 17 retratam as opções dos produtores na eleição ocorrida para a escolha de deputados federais e estaduais, em 1998. Do total dos entrevistados, $16 \%$ votaram em candidatos a deputado federal identificados com o setor leiteiro, enquanto $59 \%$ optaram por candidatos sem nenhum vínculo com esta atividade e nem mesmo com o setor agrícola. Em relação à opção dos produtores para a escolha de candidatos a deputado estadual, $11 \%$ optaram por vinculados aos interesses dos produtores de leite, enquanto $60 \%$ escolheram candidatos que se identificavam com questões urbano-industriais. 


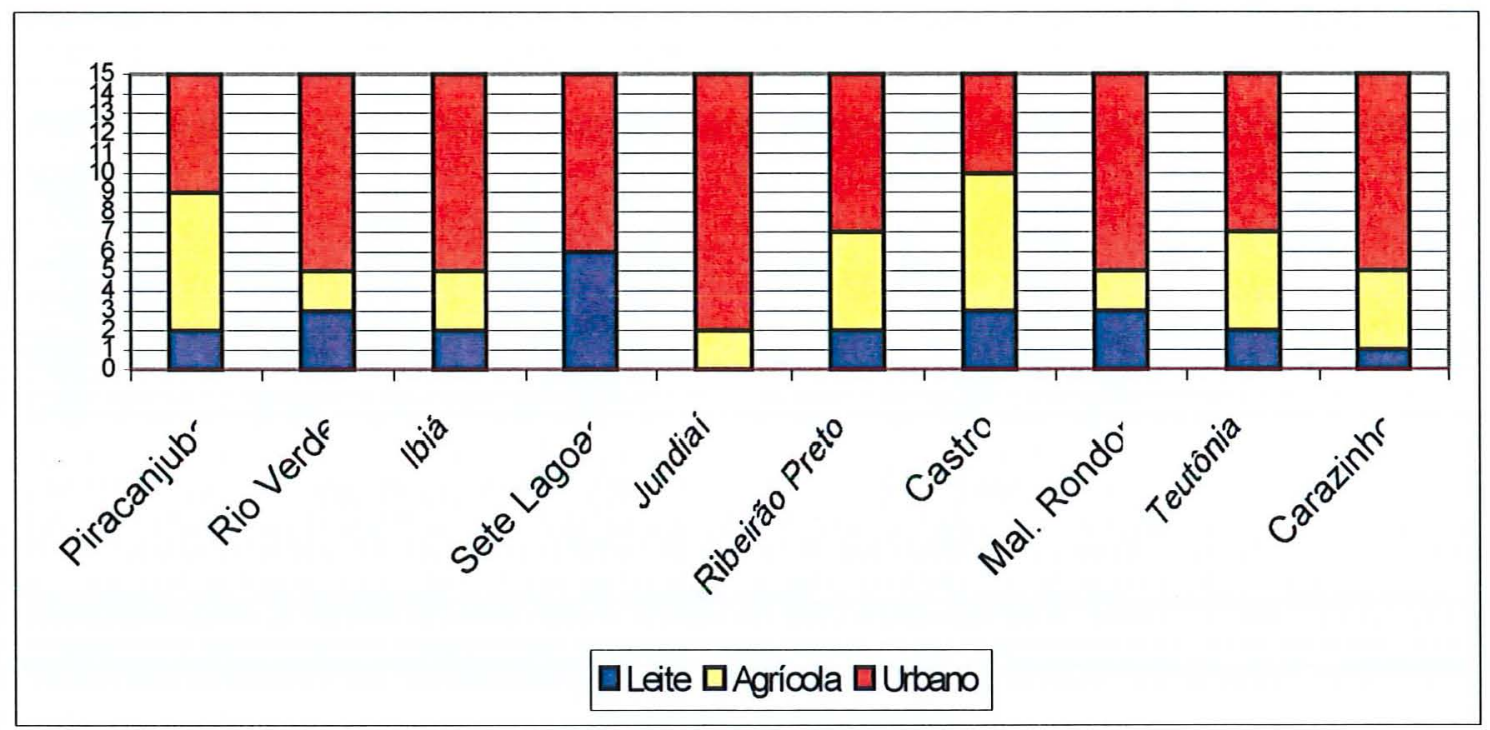

Figura 16 - Opção de voto dos produtores em candidatos ao Legislativo Federal em 1998, por corredor.

Fonte: Dados da pesquisa

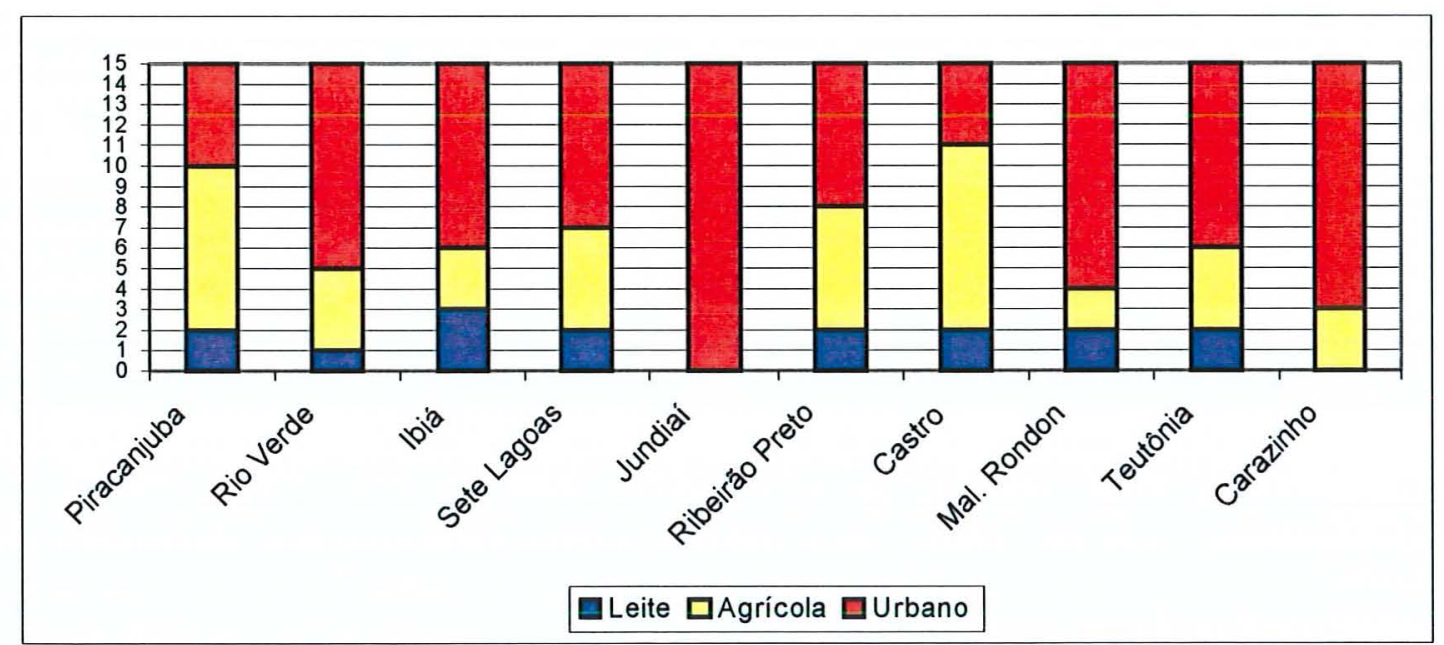

Figura 17 - Opção de voto dos produtores em candidatos ao Legislativo Estadual em 1998, por corredor.

Fonte: Dados da pesquisa 
Entre os corredores, Jundiaí não optou por nenhum candidato a deputado federal e estadual vinculado ao leite. Dos entrevistados, $87 \%$ e $100 \%$ afirmaram que escolheram candidatos aos legislativos federal e estadual, respectivamente, sem nenhum vínculo com o setor primário. No corredor Carazinho, somente um produtor afirmou ter votado em candidato a deputado federal identificado com o leite e nenhum escolheu candidato ao legislativo estadual com essas características. No âmbito estadual, os produtores desse corredor optaram, em $80 \%$ dos casos, por candidatos com discurso voltado ao setor urbano.

Por estado, os produtores dos corredores de Minas Gerais foram os que mais votos atribuíram a candidatos que tinham propostas voltadas para a atividade leiteira. Para deputados federal e estadual corresponderam a $27 \%$ e $17 \%$, respectivamente. O Paraná apresentou $20 \%$ e $10 \%$, seguido de Goiás, com $16 \%$ e $10 \%$. Os demais estados atribuíram $10 \%$ ou menos, de votos para candidatos a deputado federal e $7 \%$ ou menos, para candidatos a deputado estadual comprometidos com a atividade leiteira. Por outro lado, os estados que mais votos destinaram a candidatos a deputado federal comprometidos com setores não agrícolas foram São Paulo (73\%) e Minas Gerais (63\%), seguidos do Rio Grande do Sul (60\%), Goiás (53\%) e Paraná (50\%). Para candidatos a deputado estadual, novamente São Paulo foi o estado em que mais produtores escolheram candidatos não comprometidos com o leite e outras atividades agrícolas: $73 \%$. O Rio Grande do Sul apareceu em segundo lugar com 70\%, seguido de Minas Gerais (57\%), e Goiás e Paraná, ambos com 50\% cada.

\subsection{Considerações finais}

Este capítulo objetivou caracterizar as propriedades e os produtores que compõem os dez corredores, em termos de variáveis representativas de competitividade e eficiência. Pelos requisitos estabelecidos, tanto em termos de escolha de corredores quanto de produtores selecionados, o que caracterizou 
uma amostragem não aleatória, esperava-se que fosse possivel encontrar sistemas de produção bem definidos em cada região. A amplitude de variação quanto à produção, número de vacas e área destinada à atividade leiteira num mesmo corredor demonstrou, contudo, a dificuldade de se estabelecer sistemas de produção representativos no Brasil.

Alguns sinais de regionalização de características foram identificados, contudo. Rebanhos especializados e a utilização de sistemas poupadores de terra foram encontrados com maior incidência na região sul. Gastos com alimentação em pastagens foram inferiores no sul, por exemplo, onde o fator terra é mais caro. Isso poderia também explicar a opção pelo tipo de rebanho utilizado. Por outro lado, das 150 propriedades amostradas, 26 tiveram prejuízos. Dessas, uma parcela muito expressiva (23) opera com pequena produção, inferior à média do corredor. Assim, é possivel inferir a existência de economia de escala para essas unidades produtivas, numa perspectiva de longo prazo.

A celebração de contratos formais entre produtores e indústria de laticínios - uma bandeira de lideranças de produtores, não obteve posição consensual. Considerando-se a elevada especificidade de ativos na atividade, principalmente após a adoção da coleta de leite granelizada, era de se esperar que os produtores fossem amplamente favoráveis ao abandono da prática tradicional em termos de relações com a indústria. Além disso, os custos de transação entre os agentes são elevados. É possivel, contudo, que as instabilidades de oferta de leite "in natura" e de demanda por leite e derivados, bem como a falta de padronização do leite como matéria prima crie desestímulos para a perpetuação de contratos informais.

Em termos de valorização das instituições, ponto fundamental numa atividade que sofre impacto direto da ação do governo, percebeu-se que os produtores em geral pouco nelas acreditam. É restrito o número de 
sindicalizados e desconhecidas as principais entidades nacionais atuando em defesa de seus interesses. Além disso, os produtores de leite mostraram-se pouco atualizados sobre medidas de governo que afetam diretamente os seus negócios. Isso se reproduziu também no desconhecimento dos critérios de bonificação de preços fixados pela indústria. Há, contudo, um ganho sob este aspecto, pois a resistência a adoção de preços diferenciados recebidos pelos produtores foi insignificante, ao contrário do passado recente. Com efeito, isso parece fundamental para melhorias na cadeia, pela via de melhor qualidade e na redução de custos da matéria prima, numa perspectiva de especialização.

Quanto às instituições, é possível que o maior desencontro ocorra entre a visão do produtor e a atuação do legislativo. Esse poder foi reprovado pelos produtores quando estavam em curso Comissões Parlamentares de Inquérito sobre leite em todos os estados analisados - à exceção de São Paulo. Essas comissões concluíram por ações oportunistas desses setores, face a existência de assimetria de informações. A repercussão na mídia foi intensa. Ainda assim, os produtores de leite não a avaliaram favoravelmente. $O$ contraditório deste comportamento, contudo, deu-se pela declaração dos produtores de leite, que em sua maioria votaram em candidatos ao Legislativo com propostas de defesa de interesses urbanos. Com efeito, rechaçaram a ação legislativa em relação aos seus interesses, mas não se fizeram representar no Parlamento. 


\section{IMPACTO DE POLÍTICAS PÚBLICAS E FALHAS DE MERCADO NO SAG DO LEITE}

O presente capítulo objetivou analisar a eficiência e a competitividade em 150 das propriedades leiteiras amostradas e nas cadeias produtivas do Leite Longa Vida e do Leite em Pó, para cada corredor. Sua organização se deu nas seguintes seções. Em 5.1 é apresentado o modelo de equilíbrio geral de comércio internacional, de onde deriva a Matriz de Análise Política - MAP, instrumental utilizado para as mensurações de competitividade e eficiência. Na seção 5.2 é operacionalizada esta Matriz e são apresentados os indicadores dela extraídos para a análise.

$\mathrm{Na}$ seção 5.3 estão relacionados trabalhos que se valeram do instrumental MAP, tanto para estudos de produtos, quanto para corredores. A fonte de dados e os procedimentos adotados são apresentados na seção 5.4 .

Em 5.5 são apresentados os resultados obtidos para as propriedades e para as cadeias produtivas, separadamente, e para cada corredor estudado. Também são encontradas simulações relativas à eficiência e à competitividade das cadeias produtivas nos corredores, considerando variações no custo de fatores de produção, no preço do produto e na produtividade. São estimados valores de comercialização em São Paulo que anulariam a competitividade e a eficiência das cadeias, por corredor. Na seção 5.6 são feitas considerações finais. 


\subsection{Matriz de Análise Política}

Os preços praticados no mercado internacional e a tecnologia são os principais suportes para análises de eficiência e avaliação social de processos agrícolas de produção. O uso do modelo de equilíbrio geral de produção neste capítulo visa mostrar como uma economia pode atingir o seu mais alto nivel de produção e renda, quando internaliza os preços do mercado mundial. Os preços dos fatores são determinados neste processo de maximização, permitindo estabelecer a base para uma avaliação de novos sistemas de produção que venham a se estabelecer na economia. Dessa forma, se um sistema de produção não é eficiente para remunerar os fatores domésticos, em termos de preços internacionais, entendido como custos sociais, espera-se que a renda nacional cresça se os fatores domésticos forem alocados em outros sistemas produtivos existentes na economia.

Considera-se o modelo a seguir. A Figura 18 retrata uma economia que produz dois bens $M$ e $N$, com oferta fixa de dois fatores de produção domésticos, Capital e Trabalho. Ambos são necessários na produção dos referidos bens. $M$ e $N$ são produzidos com retornos constantes à escala, ou seja, os processos de produção são representados por função de produção homogênea de primeiro grau. Se todos os fatores forem alocados na produção de $M$, obtém-se o produto $E$. Do mesmo modo, o ponto $F$ representa a produção máxima possível, com a alocação de todos os fatores na produção de $N$. O Ponto $Z$ representa uma combinação intermediária de fatores para a produção de certa quantidade de $M$ e $N$. 


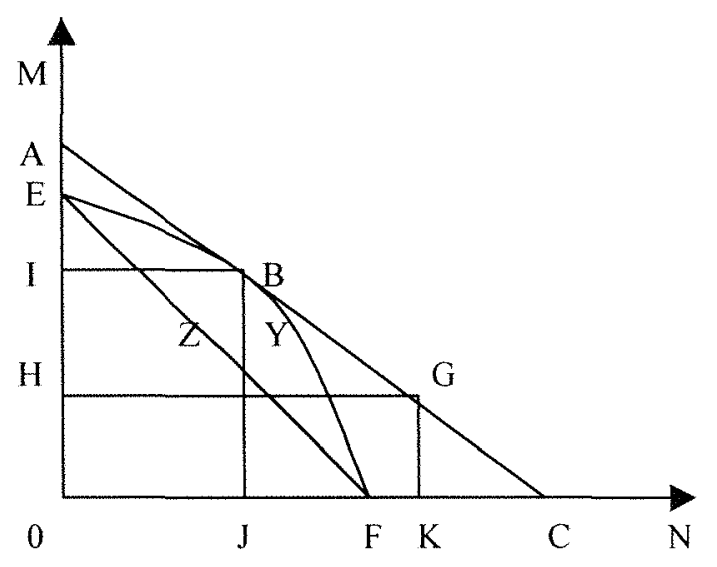

Figura 18 - Fronteira de Possibilidades de Produção.

Fonte: Monke \& Pearson (1989)

Assume-se também que os fatores podem ser substituídos entre si, ou seja, a função de produção é bem comportada. Ademais, não há inversão na intensidade de uso dos fatores e o ajuste é instantâneo, de modo que a economia está sempre em equilibrio. Se os fatores apresentam produtividades diferentes nos dois processos produtivos, o produto total pode ser acrescido, ao se promover diferentes combinações alocativas dos fatores entre os produtos. Com efeito, realocando os fatores, é possivel que a produção de $M$ permaneça a mesma e a produção de $N$ cresça. Isso é representado no ponto $Y$. Ao se assumir retornos marginais decrescentes para os insumos, é de se supor que a curva de produção máxima será côncava à origem. A curva de Fronteira de Possibilidades de Produção é então representada pela curva EBYF. Movimentos ao longo desta curva expressam o custo de oportunidade na produção de um bem em termos de outro bem. A curva também pode ser interpretada como possibilidades de consumo em uma economia fechada, ou seja, auto-suficiente. 
Quando se considera a possibilidade de transações com o restante do mundo, as oportunidades de consumo se expandem além da curva de possibilidades de produção. Se a economia do país é pequena e não influencia os preços de produtos no mercado internacional, os preços externos vigentes podem ser representados pela curva $A B G C$. Todos os pontos ao longo desta curva representam combinações de bens $M$ e $N$ aos preços do mercado internacional. Consequentemente, a inclinação dessa curva é dada pela relação de preços dos bens $N$ e $M$ naquele mercado. Ou seja,

$$
\triangle M \times P M=-\triangle N \times P N
$$

onde $P M$ e $P N$ representam, respectivamente os preços dos produtos $M$ e $N$. Rearranjando os termos,

$$
\frac{\Delta M}{\Delta N}=-\frac{P N}{P M}
$$

ou seja, a inclinação da linha de oportunidades de comércio, representada pelo lado esquerdo da expressão (2), também pode ser expressa pela taxa negativa dos preços mundiais ou termos de troca, representada pelo lado direito desta expressão. A definição que bem será exportado e que bem será importado, depende das preferências dos consumidores domésticos. Se a opção é, por exemplo, manter uma estrutura de consumo como o representado pelo ponto $G$, isso implicará exportar $H I$ do bem $M$ e importar $J K$ do bem $N$. A escolha de consumo de um ponto que esteja ao longo do segmento $A B$, implicaria um movimento inverso, ou seja, importar determinada quantidade do bem $M$ e exportar parte do bem $N$ que for produzido internamente.

A curva $A B G C$ representa a Fronteira de Possibilidades de Consumo para uma economia. Nenhuma outra curva de possibilidades de comércio, de inclinação - $P N / P M$, incluiria um ponto sobre a curva de possibilidades de 
produção e ainda tornaria possivel o consumo de expressivas quantidades dos dois bens.

Somente no ponto $B$ esta economia estaria em equilíbrio autárquico. Dada a nova relação de preços internacionais vigentes internamente, este país realocaria os fatores de produção e, em vez de produzir e consumir uma quantidade de bens $M$ e $N$ representada pelo ponto $Y$, como no início da análise, estaria consumindo uma quantidade menor de $N$ e maior de $M$, mas ainda assim, sem transações com o restante do mundo. Caso a preferência dos consumidores recaia sobre o consumo de bens $M$ e $N$ em quantidades que sejam representadas por quaisquer outros pontos ao longo da curva $A B G C$, haveria necessidade de se importar uma quantidade de um bem que, em valor, equivaleria à exportação de outro bem. Ao longo desta curva todos os pontos são de igual valor. Nesta análise são assumidas algumas premissas que asseguram que, após a abertura da economia, o preço interno será o mesmo que aquele verificado no mercado internacional. Entre elas, ausência de custos de transporte, livre comércio e concorrência perfeita em todos os mercados, inclusive no mercado de fatores.

Os preços do mercado internacional para produtos transacionáveis no modelo de equilíbrio geral são considerados preços sociais, pois permitem que a economia atinja a curva de fronteira de possibilidades de consumo. Para operacionalizar esta consideração, são requeridos a taxa de rentabilidade do capital $r$, dada pela taxa de juros e de depreciação, e a taxa de salários para o trabalho $w$. Mantendo-se a suposição de oferta fixa de fatores, os preços dos fatores são determinados pelos preços dos produtos e pela tecnologia de produção. A suposição de mercados competitivos, inclusive para os fatores, assegura lucros normais. Portanto, custos e receitas totais podem ser expressos como uma igualdade:

$$
w L_{\mathrm{I}}+r K_{\mathrm{I}}=P_{M} M
$$




$$
w L_{2}+r K_{2}=P_{N} N
$$

onde $L$ e $K$ representam, respectivamente, quantidades dos fatores trabalho e capital. Dividindo por $M$ e $N$, tem-se

$$
\begin{aligned}
& w \frac{L_{1}}{M}+r \frac{K_{1}}{M}=P_{M} \\
& w \frac{L_{2}}{N}+r \frac{K_{2}}{N}=P_{N}
\end{aligned}
$$

onde $L_{1} / M, L_{2} / N, K_{1} / M$ e $K_{2} / N$ retratam o uso de fatores por unidade de produto. Renomeando a equação (4), os novos termos representam, portanto, coeficientes insumo-produto. Assim, tem-se que:

$$
\begin{aligned}
& w l_{1}+r k_{1}=P_{M} \\
& w l_{2}+r k_{2}=P_{N}
\end{aligned}
$$

A equação (5) reproduz uma condição de lucro zero. Representa, portanto, uma situação em que preços e tecnologia não variam. Na realidade, raramente os setores produtivos apresentam lucro zero, pois os preços dos produtos e a tecnologia estão frequentemente variando. Dessa forma, os custos totais são maiores ou menores que as receitas totais. O uso da condição de lucro zero, como uma base para se determinar preço social, permite medir incentivos no equilíbrio de longo prazo, assumindo-se que a condição de lucro negativo ou supernormal prevalecerá somente no curto prazo.

Uma manipulação algébrica da equação (5) permite verificar como os preços dos fatores usados no processo produtivo são dependentes dos preços dos produtos e dos coeficientes insumo-produto: 


$$
w=\left(\frac{P_{M} k_{2}-P_{N} k_{1}}{l_{1} k_{2}-l_{2} k_{1}}\right) r=\left(\frac{P_{N} l_{1}-P_{M} l_{2}}{l_{1} k_{2}-l_{2} k_{1}}\right)
$$

Estes custos de fatores representam os custos sociais de oportunidade dos fatores usados num processo de obtenção de um novo produto $Q$. Caso a produção de $Q$ não apresente lucratividade compativel cóm a apresentada pelos fatores domésticos aos preços de $w$ e $r$, a renda nacional não poderá crescer com a produção deste novo produto $Q$. A economia estaria em melhor situação, mantendo a produção restrita a $M$ e $N$. O cálculo da MAP trata o sistema sob estudo como um novo sistema de produto. Assim, os custos de oportunidade social dos fatores são determinados por outros produtos na economia. Lucros sociais então representam a contribuição líquida do sistema do produto à renda nacional.

As equações insumo-produto podem ser expandidas como na equação (7)

$$
\begin{gathered}
w_{1} Z_{11}+w_{2} Z_{21}+w_{3} Z_{31}+\cdots+w_{m} Z_{m 1}=P_{1} Q_{1} \\
w_{1} Z_{12}+w_{2} Z_{22}+w_{3} Z_{32}+\cdots+w_{m} Z_{m 2}=P_{2} Q_{2} \\
\vdots \\
w_{1} Z_{1 n}+w_{2} Z_{2 n}+w_{3} Z_{3 n}+\cdots+w_{m} Z_{m n}=P_{n} Q_{n}
\end{gathered}
$$

em que:

$w_{i}=$ preço do i-ésimo fator

$P_{i}=$ preço do i-ésimo produto

$Q_{j}=$ quantidade do j-ésimo produto

$Z_{i j}=$ quantidade do i-ésimo insumo usado na produção do j-ésimo produto

Dividindo-se até a n-ésima equação por Qj tem-se: 


$$
\begin{gathered}
w_{1} a_{11}+w_{2} a_{21}+w_{3} a_{31}+\cdots+w_{m} a_{m 1}=P_{1} \\
w_{1} a_{12}+w_{2} a_{22}+w_{3} a_{32}+\cdots+w_{m} a_{m 2}=P_{2} \\
\vdots \\
w_{1} a_{1 n}+w_{2} a_{2 n}+w_{3} a_{3 n}+\cdots+w_{m} a_{m n}=P_{n}
\end{gathered}
$$

Alguns insumos usados na produção dos bens são transacionáveis e outros são tipicamente domésticos. Assumindo-se que $Z_{1}$ até $Z_{4}$ representam insumos que utilizam fatores domésticos, e $Z_{5}$ até $Z_{m}$ são insumos transacionáveis plenamente, as equações podem ser reescritas, separando-se os insumos que utilizam fatores domésticos, daqueles insumos que usam fatores transacionáveis, conforme equação (9):

$$
\begin{gathered}
w_{1} a_{11}+w_{2} a_{21}+w_{3} a_{31}+w_{4} a_{41}=P_{1}-P_{5} a_{51}-\cdots-P_{m} a_{m 1} \\
\vdots \\
w_{1} a_{1 n}+w_{2} a_{2 n}+w_{3} a_{3 n}+w_{4} a_{4 n}=P_{n}-P_{5} a_{5 n}-P_{m} a_{m n}
\end{gathered}
$$

onde $W_{5} \ldots W_{m}$ foram substituídos por preços mundiais $P_{5} \ldots P_{m}$, devido ao fato desses insumos serem também produtos transacionáveis.

O lado direito da equação representa agora o valor adicionado ao preço do produto. Em formato matricial, a equação (9) pode ser escrita como se segue

$$
\left[\begin{array}{llll}
w_{1} & w_{2} & w_{3} & w_{4}
\end{array}\left[\begin{array}{llll}
a_{11} & a_{12} & \cdots & a_{1 n} \\
a_{21} & a_{22} & \cdots & a_{2 n} \\
a_{31} & a_{32} & \cdots & a_{3 n} \\
a_{41} & a_{42} & \cdots & a_{4 n}
\end{array}\right]=\left[\begin{array}{lllll}
V A_{1} & V A_{2} & \cdots & V A_{n}
\end{array}\right]\right.
$$


A equação (10) é uma outra forma de apresentar a condição de lucro zero. Os preços dos fatores domésticos, multiplicado pelos coeficientes insumoproduto, equivalem aos valores adicionados no processo produtivo.

Ao assumir o pressuposto de equilíbrio geral, a medida de eficiência da MAP é o lucro social, ou seja, a mudança líquida na renda nacional resultante da introdução de um sistema de "commodities" na economia. Já no diagrama de equilíbrio parcial, a medida de eficiência se dá pela diferença incremental entre os benefícios socais e os custos sociais.

A Figura 19 compara medidas de eficiência em termos de equilíbrio parcial e na MAP. A curva de custo marginal de uma firma é representada pela curva uvwxys. Analisa-se uma política de taxação sobre a produção de um produto exportável, o que faz com que os preços internos $P_{i}$ sejam menores que os preços internacionais $P_{m}$. A produção total então é $Q_{i}$, menor que a produção $Q_{m}$, a ser obtida na vigência de preços internacionais. O custo da eficiência desta política, sob a ótica de equilíbrio parcial, é dado pela área $Q_{m} \vee x Q_{i}$.

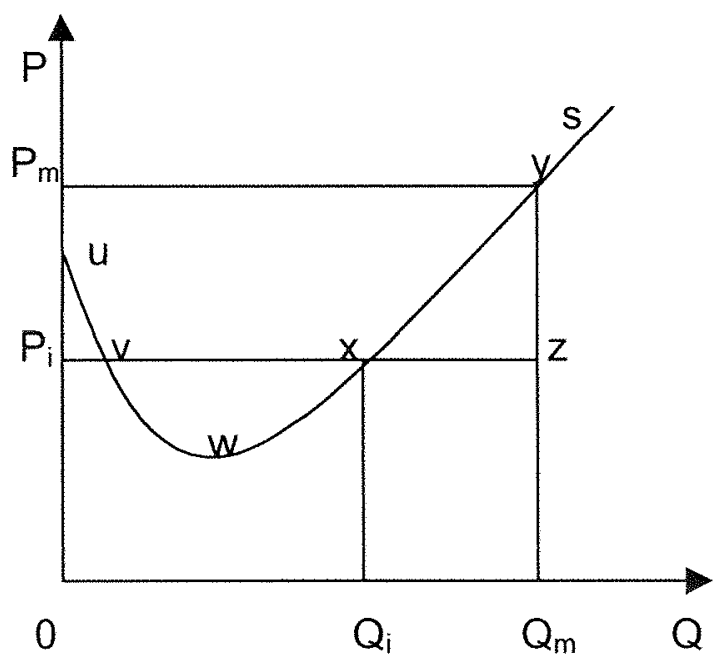

Figura 19 - Efeitos de políticas na MAP.

Fonte: Monke e Pearson (1989) 
Quando se considera a MAP, as receitas privadas e sociais correspondem respectivamente aos retângulos formados pelos preços privados e sociais e as respectivas quantidades produzidas. As medidas de custos totais de produção são representadas pelas áreas abaixo da curva de custo marginal, tanto para os preços domésticos ou privados, quanto para os preços internacionais ou sociais. O custo de eficiência dessa política será dada em termos de receitas, custos e lucros, face as divergências obtidas quando aferidas em preços privados e preços sociais. O Quadro 5 reproduz as áreas relevantes denotadas pela Figura 19.

\begin{tabular}{|c|c|c|c|}
\hline & Receitas & Custos & Lucros \\
\hline Preços Privados & $\mathrm{OP}_{\mathrm{i}} \times \mathrm{Q}_{\mathrm{i}}$ & OuvwXQ $Q_{i}$ & $(v w x)-\left(u v P_{i}\right)$ \\
\hline Preços Sociais & $O P_{m} y Q_{m}$ & OurwxyQ & $P_{m} u v w x y$ \\
\hline Efeitos de Divergência & $-\left(P_{m} y z P_{i}\right)-\left(Q_{m} z x Q_{i}\right)$ & $-\left(Q_{m} z x Q_{i}\right)-(x y z)$ & $-\left(P_{m} y \times Q P_{i}\right)$ \\
\hline
\end{tabular}

Quadro 5 - Comparação de mensuração de efeitos de políticas entre matriz de análise política e modelo de equilíbrio parcial.

Fonte: Monke e Pearson (1989)

A diferença entre as medidas de eficiência por meio de equilibrio parcial e MAP surge porque, na MAP, o lucro social capta a contribuição total do sistema para a renda nacional, enquanto que na análise de equilíbrio parcial mede-se o impacto incremental da política de preços. Na MAP, o impacto incremental da política de preços entra como parte dos efeitos de divergência do lucro, que é a diferença entre lucros sociais e privados, ou o efeito líquido de políticas no sistema. Esse valor inclui as transferências líquidas dos produtores e as perdas de eficiência. 


\subsection{Operacionalização da MAP}

Num modelo de equilibrio geral, se todos os mercados estruturam-se em condições de competição perfeita, maximizam-se a tanto a alocação de recursos, e consequentemente a produção, quanto a satisfação dos consumidores, no conceito de Ótimo de Pareto. Os preços de equilibrio em cada um dos mercados individuais são, assim, preços de eficiência.

Em termos reais, raramente os mercados apresentam todas as características de competição perfeita. No caso do leite, as condições de mercado divergem da competição perfeita, caracterizando-se como um mercado distorcido ou imperfeito.

O sistema de preços em uma economia contém duas importantes informações: reflete escassez relativa e indica incentivos à produção e ao consumo. A análise de preços relativos é, portanto, relevante na discussão de competitividade e eficiência. Para a análise de eficiência, é usual ter o conceito de custo de oportunidade como referência. Uma comparação entre preços observados e seus respectivos custos de oportunidade poderá detectar distorções, dada a diferença entre os mesmos. Distorções crônicas levam a ineficiências.

Os mercados podem apresentar distorções de dois tipos. Distorções endógenas ou falhas de mercado são aquelas que se verificam em função da forma em que o mercado se estrutura, com a presença de poder de mercado, informação assimétrica ou imperfeita, bens públicos e externalidades. Distorções exógenas são resultantes de ações implementadas por políticas públicas, macroeconômicas ou setoriais, que interferem no funcionamento e nos resultados do mercado, com o propósito de atingir objetivos próprios de governo, que necessariamente não são a eficiência econômica, como o atendimento de interesses de grupos específicos da sociedade. 
$\mathrm{Na}$ presença de distorções endógenas ou exógenas, os preços efetivos de equilibrio divergem dos preços de eficiência que prevaleceriam, caso o mercado fosse de competição perfeita. Assim, a alocação de recursos não é ótima e a produção e o nível de utilidade colocam-se aquém do que seria possível.

A MAP permite analisar as distorções de mercado em um SAG e foi desenvolvida por Scott Pearson do Food Research Institute, da Universidade de Stanford, e apresentada em Monke e Pearson (1989). Os autores estabelecem que este instrumental é relevante para (p. 17):

- aferir o impacto de políticas sobre a competitividade de sistemas de mercadorias;

- aferir o impacto de políticas de investimento sobre a eficiência e vantagem comparativa;

- aferir os efeitos de políticas de pesquisa agrícola sobre os caminhos do processo de mudança tecnológica em direções desejáveis.

Sua primeira aplicação diz respeito à competitividade. Os resultados podem ser usados para identificar sistemas de produção competitivos, sob o efeito de políticas correntes e falhas de mercado afetando uma atividade agrícola. A obtenção de lucros é um importante resultado inicial, pois mostra se os sistemas são de fato competitivos e como os lucros variam, caso ocorram mudanças de políticas.

A segunda aplicação refere-se a eficiência ou vantagens comparativas dos sistemas agrícolas e como investimentos públicos adicionais podem interferir no nível de eficiência entre produtores. Assim, é possível verificar, dado um pacote tecnológico previamente estabelecido, em que regiões de um país, com suas peculiaridades agroclimáticas, uma atividades tem vantagens comparativas e qual o montante de recursos públicos é 
necessário para transformar essas vantagens em realidade. A diferença entre receitas e custos para um sistema, medidos a preços de mercado internacional, é uma medida de eficiência econômica. Investimentos públicos que reduzem custos e aumentam o lucro fazem crescer a eficiência.

Uma terceira contribuição está relacionada a melhor alocação de fundos para pesquisa agrícola. É possível determinar em que extensão lucros reais são gerados por transferências de políticas ou por eficiência econômica. Os pesquisadores agrícolas podem simular diferentes tecnologias e seus diferentes impactos sobre os sistemas de produção, escolhendo as melhores alternativas.

Ao analisar as diversas aplicações possiveis para a MAP, Kydd et al. (1997) afirmam ser relevante, numa análise de distorções de políticas, adicionar o instrumental da Nova Economia das Instituições. Este instrumental pode prover "insights" sobre as razões que levam a saída do Estado do mercado, bem como a remoção de distorções políticas que não necessariamente levam a maior competitividade e eficiência nos sistemas de mercado. Eles entendem que é útil considerar os pressupostos da escola dos custos de transação, das instituições e outros mecanismos de contratos existentes. A junção de ambos instrumentais possibilitaria o enriquecimento de análises, por permitir abordagens qualitativa e quantitativa.

A MAP é resultante de duas identidades contábeis. Lucratividade é dada pela diferença entre receitas e custos. A outra identidade é uma medida de divergências ou distorções de políticas públicas ou falhas de mercado. Sua dimensão se dá pela diferença entre preços observados e preços que poderiam ser vigentes, na ausência de distorções. Lucros são definidos como a diferença entre receitas totais e custos de produção.

Cada MAP contém duas colunas de custo: uma para insumos intermediários transacionáveis, e outra para fatores domésticos. Essa 
desagregação leva a quatro categorias de bens e serviços: insumos transacionáveis, fatores domésticos, insumos não transacionáveis e transferências, que seriam impostos ou subsídios.

O Quadro 6 reproduz a MAP. A primeira linha fornece uma medida de lucratividade privada. O termo privada refere-se, nessa abordagem, a receitas e custos efetivamente recebidos e pagos por fazendeiros, processadores, ou por qualquer agente econômico em análise. Reflete, portanto, preços de mercado doméstico. No referido Quadro, LP retrata os lucros privados e são obtidos pela diferença entre as receitas a preços privados $(R M)$ e os custos a preços privados, representados pelo somatório de Insumos transacionáveis (IM) e fatores domésticos (FM).

\begin{tabular}{|lcc|cc|}
\hline & Receitas & \multicolumn{2}{c}{ Custos } & Lucros \\
\cline { 3 - 5 } & & $\begin{array}{c}\text { Insumos } \\
\text { Transacionáveis }\end{array}$ & $\begin{array}{c}\text { Fatores } \\
\text { Domésticos }\end{array}$ & \\
\hline $\begin{array}{l}\text { Preços Privados } \\
\text { (preços de mercado) }\end{array}$ & $R M$ & IM & $F M$ & LP \\
$\begin{array}{l}\text { Preços Sociais } \\
\text { (custo de oportunidade) }\end{array}$ & $R S$ & IS & $F S$ & $L S$ \\
$\begin{array}{l}\text { Transferência de Políticas } \\
\text { e de Falhas de Mercado }\end{array}$ & $O T$ & $I T$ & $F T$ & $T L$ \\
\hline
\end{tabular}

Quadro 6 - Matriz de Análise Política-MAP.

Fonte: Adaptado de Monke e Pearson (1989)

O cálculo da lucratividade privada revela a competitividade do sistema, sendo dados a tecnologia empregada, o preço do produto, os custos dos insumos e as transferências de políticas, que podem ser positivas ou negativas. O custo do capital é definido como a taxa de retorno requerido para a manutenção do capital próprio no investimento. Este valor é considerado no cálculo dos custos domésticos (FM). Dessa forma, caso os Lucros Privados (LP) sejam positivos, os agentes estão auferindo lucros extras, o que levaria a 
uma expansão do sistema. Se LP é zero, o agente permanece na atividade, mas não tem estímulo para expandi-la. Caso $L P$ seja menor que zero, o agente terá estímulos à abandonar a atividade, se nenhum fator concorrer para que haja alguma mudança em sua lucratividade.

A segunda linha da matriz considera os preços sociais e mede eficiência ou vantagem comparativa no sistema agrícola em análise. Os Lucros Sociais (LS) são medidas de eficiência, pois são obtidos a preços que refletem custos de oportunidade ou quão escassos são os recursos.

Para produtos e insumos transacionáveis, os valores sociais a serem considerados deverão ser os praticados no mercado mundial. Como retratam vantagens comparativas, o país tem a opção de alocar fatores na obtenção de insumos e produto, ou importá-los. O preço vigente no mercado internacional é, portanto, o custo de oportunidade de se alocar fatores de produção para a obtenção de insumos transacionáveis e do produto. Monke e Pearson (1989) argumentam que os preços mundiais representam um parâmetro de comparação para a escolha do governo permitindo que consumidores e produtores importem, exportem, ou produzam bens e serviços domesticamente. Para Tsakok (1990), mesmo que os preços no mercado internacional sejam resultantes de dumping, cartel ou outra forma de poder de mercado, ainda assim devem ser considerados. Representam o que o país tem de pagar para obtê-los, no caso de uma comparação entre produzir e importar. O custo de oportunidade de produtos e insumos transacionáveis deverá ser os seus preços nesse mercado, portanto, convertido a uma taxa de câmbio.

Os serviços ofertados por fatores domésticos de produção como trabalho, terra e capital devem ser considerados a preços domésticos. O valor social de cada um destes fatores é encontrado pela estimativa da renda líquida perdida pelo não emprego em seu melhor uso alternativo. Para produtos não 
transacionáveis, portanto, o custo de oportunidade será dado por seus preços sombra.

Para trabalho e capital, que são fatores móveis, os preços são determinados por oferta agregada e forças de demanda. Usos alternativos desses fatores são disponíveis na economia. A determinação de valores sociais deverá considerar a economia como um todo e não somente o setor agrícola. Já fatores imóveis como terra, têm a determinação de valores sociais gerados entre diferentes alternativas de uso, mas dentro do próprio setor agrícola.

Para cada entrada da MAP, analisando-a verticalmente, qualquer divergência entre os preços privados e os preços sociais, para receitas, custos e lucros, são efeitos de políticas e/ou de existência de falhas de mercado. Monke e Pearson (1989) afirmam que nem todas as políticas distorcem a alocação de recursos. Algumas podem ser introduzidas para corrigir falhas de mercado, como a existência de monopólios ou monopsônios, externalidades ou mercado de fatores imperfeitos.

Transferências do Produto (OT), cujo valor é calculado pela subtração das receitas obtidas a preços privados (RM) e preços sociais (RS), bem como Transferências dos Insumos (IT) que também tem valor calculado pela subtração entre os preços privados dos insumos $(I M)$ e os preços sociais (IS), têm origem de duas fontes de políticas, além das falhas de mercado. A primeira diz respeito especificamente a políticas voltadas para o produto, como impostos, subsídios, quotas de importação e preços mínimos. A segunda refere-se a taxa de câmbio, que pode estar sobrevalorizada ou subvalorizada, afetando os cálculos, na medida em que é necessário converter para moeda nacional os preços vigentes no mercado internacional, para que se obtenha os preços sociais a serem considerados. Há também a possibilidade de decisões de governo afetarem um ou mais fatores, por meio de impostos, subsídios ou 
decisões legais que criem divergências entre os custos privados e os custos sociais.

Como resultado, são obtidos indicadores que possibilitam a interpretação dos efeitos de divergência, gerados por políticas públicas ou imperfeição de mercado. O primeiro conjunto refere-se às transferências focadas no produto, e é definido como a diferença entre os preços reais de mercado para um produto e os preços sociais encontrados (OT=RM-RS). Se OT é positivo, os preços do produto no mercado estão acima daqueles que seriam praticados, na ausência de políticas e de falhas de mercado. Na coluna de receitas da saída da MAP afere-se o Coeficiente de Proteção Nominal $(C P N)$, que é dado por:

$$
C P N=\frac{R M}{R S}
$$

Valores acima da unidade indicam que as condições vigentes possibilitaram que os preços privados ficassem algum porcentual acima dos preços vigentes no mercado internacional, traduzindo em proteção. Dessa forma, se CPN encontrado for de 1,25, o produto em questão tem preços no mercado doméstico $25 \%$ acima daqueles praticados no mercado internacional. Valores inferiores à unidade traduzem desproteção ou taxação ao produto. $O$ CPN, portanto, permite comparar a receita a preços domésticos em relação à receita, a preços internacionais. A razão entre ambas indica a extensão de estímulos positivos ou negativos, via preços, ao setor produtivo.

Uma segunda informação é a Transferência de Insumos Transacionados (IT), dada pela diferença entre o valor dos insumos no mercado e em termos sociais $(I T=I M-I S)$. Se $I T$ é positivo, ocorre uma taxação sobre os insumos transacionáveis. O inverso aconteceria se o conjunto de políticas levasse a um subsidio aos insumos. Um indicador relevante pode ser retirado deste item. Trata-se do Coeficiente de Proteção Efetiva (CPE) que é dado por: 


$$
C P E=\frac{(R M-I M)}{(R S-I S)}
$$

O CPE indica a extensão dos incentivos ou taxações que o sistema recebe de políticas voltadas para o produto. A obtenção de CPE maior que a unidade indica que o produto está sendo protegido e os fatores domésticos estão sendo remunerados acima dos preços internacionais. Os lucros privados estão sendo maiores em função de políticas e de falhas de mercado. Valores menores que a unidade indicam que o sistema está recebendo retornos inferiores àqueles que poderiam ser obtidos, no caso da ausência de distorções. Há desestímulo, traduzido em taxação ou desproteção.

Este indicador tem suas limitações por não incorporar efeitos incidentes sobre os preços dos fatores. Isso porquê, o CPE mede os efeitos de incentivos derivados de políticas de preços para o produto, mas não pode ser visto como um indicador do impacto total de políticas que influenciam preços e custos.

Transferência de Fatores ( $F T)$ é o terceiro conjunto de indicadores, definido pela diferença entre os custos a preços de mercado e sociais dos fatores domésticos, ou seja :

$$
F T=F M-F S
$$

Caso FT seja positivo, ocorre transferência positiva causada por políticas de taxação aos fatores domésticos.

Outro conjunto de indicadores refere-se a Transferências Líquidas (TL), definido como a diferença entre as Transferências do Produto (OT), Transferências de insumos transacionados (IT) e Transferência de Fatores (FT), ou seja: 


$$
T L=O T-I T-F T
$$

que também é definida como a diferença entre preços privados e sociais. Se $T L$ é positivo, mostra as ineficiências existentes no sistema em estudo. O governo pode aumentar a eficiência do sistema, reduzindo o grau de distorção.

O Coeficiente de Lucratividade, definido por

$$
C L=\frac{L P}{L S}
$$

e mede o impacto das transferências líquidas quando o lucro privado excede o lucro social ou vice-versa. $C L$ é uma medida melhor acabada que CPE, pois indica os efeitos totais de incentivos de políticas, incluindo as originárias do mercado de fator. Se $C L>1$, indica em que proporção os lucros privados suplantaram os lucros sociais.

A Razão de Custo Privado é dada por:

$$
R C P=\frac{F M}{(R M-I M)}
$$

e é uma medida de competitividade, por considerar a razão entre os custos de fatores domésticos e o valor adicionado, em termos de preços privados. A competitividade do sistema em análise é maior, quanto menor for o indicador obtido. Se $R C P$ for igual à unidade, os fatores domésticos estão apresentando retorno normal e o lucro também é normal, ou seja, zero. Nesse caso, o valor adicionado seria equivalente 'a remuneração dos fatores domésticos. Valores inferiores à unidade indicam retorno dos fatores de produção acima do normal, o que sinaliza a expansão do sistema em análise.

O Custo dos Recursos Domésticos é definido por 


$$
C R D=\frac{F S}{(R S-I S)}
$$

e retrata eficiência ou vantagem comparativa. Se $C R D=1$, os fatores domésticos estão recebendo retornos equivalentes ao seu custo de oportunidade social. Nesse ponto seria indiferente produzir internamente ou importar. Indica que o valor adicionado a preços internacionais é exatamente igual ao valor dos insumos domésticos utilizados na produção. Para $C R D<1$, a economia estaria estimulada a poupar divisas, produzindo internamente, pois o custo de oportunidade de seus recursos domésticos é menor que o custo de oportunidade social. O valor dos recursos domésticos empregados na produção, portanto, seria inferior ao valor adicionado, indicando que a expansão da atividade em estudo traria ganhos líquidos para o país. Quando CRD $>0$, a interpretação analítica seria invertida.

A Taxa de Desestímulo aos Agentes (DA) é dado por:

$$
D A=\frac{T L}{R S}
$$

e mostra o quanto as transferências líquidas originárias das divergências estão em relação à receita social. Estabelece, portanto, a magnitude das divergências em relação à receita social. Se $D A<0$, divergências levaram à diminuição da receita do sistema em análise, via impostos e/ou falhas de mercado. Para $D A>$ 0 , o inverso se aplica. Os valores de DA podem ser expressos em percentagem.

É importante definir uma taxa social de câmbio de equilibrio, para converter os preços sociais dos insumos e do produto em moeda nacional. Com esse procedimento procura-se anular interferências do Banco Central e ações especulativas. 


\subsection{Aplicações da MAP}

\subsubsection{Segmento de produção}

Um esforço conjunto das universidades de Stanford, Arizona e Egerdon viabilizou pesquisa de campo realizada em propriedades leiteiras do Quênia, para três niveis tecnológicos. O estudo concluiu que a desregulamentação, principalmente a supressão dos mecanismos de fixação de preços, reduziu de $20 \%$ a $30 \%$ os efeitos distorcivos que penalizavam a atividade primária em relação ao periodo anterior à reforma naquele país, dependendo do nível tecnológico usado nas propriedades. O mercado lácteo continuou não competitivo e a maior beneficiária da desregulamentação foi a indústria de laticínios (Staal \& Shapiro, 1994).

O estudo de Nelson \& Panggabean (1991) sobre custos de políticas para o açúcar na Indonésia valeu-se de dados primários. A conclusão do trabalho é que os produtores de cana-de-açúcar naquele país eram protegidos por políticas públicas, em detrimento dos consumidores.

A competitividade entre arroz e soja foi analisada na Tailândia por Yao (1997). Os resultados demonstraram que $o$ arroz apresentou vantagens comparativas. Ademais, políticas públicas contribuíram para a perpetuação da produção de arroz em várzeas, pois visavam objetivos sociais.

A análise de lucratividade social de tecnologias agroflorestais para a produção de milho no Camarão foi realizada por Anesina \& Coulibaly (1998). Os autores analisaram os impactos de políticas públicas sobre a competitividade na produção de milho submetida a estas tecnologias. Os resultados obtidos demonstraram que os sistemas de produção de milho que utilizaram tecnologias agroflorestais tiveram atrativas taxas de lucratividade social, em comparação com as tecnologias usualmente empregadas. 
No Brasil, Vieira (1996) comparou a competitividade de milho, trigo e soja em diferentes níveis de produtividade na região Centro-Sul do Brasil e na região do Pampa argentino. Baseando-se em planilhas de custos de produção da Companhia Nacional de Abastecimento-CONAB e do Instituto Nacional de Tecnologia Agropecuária-INTA, respectivamente do Brasil e da Argentina, concluiu que políticas públicas brasileiras discriminavam as produções desses produtos, afetando preços dos insumos, dos fatores e dos produtos. Os resultados revelaram efeitos penalizadores de políticas públicas sobre os sistemas de produção, com destaque para as políticas tributária, tarifária e cambial.

Uma análise de competitividade entre sistemas de produção de carnes de frango e de suínos em Minas Gerais e em Santa Catarina foi realizada por Rosado (1997). Utilizando coeficientes técnicos de institutos de pesquisa, concluiu que, nesses estados, as atividades apresentaram vantagens comparativas e sofreram taxações resultantes de políticas de intervenção do governo, o que promoveu transferências de renda para os consumidores.

Quanto ao leite, Campos (2001) considerou os coeficientes técnicos disponíveis na literatura e concluiu que a produção nacional é prejudicada por mecanismos de intervenção adotados no Brasil e por políticas de apoio a exportação de lácteos, implementadas em países desenvolvidos.

\subsubsection{Corredores}

A Hungria teve 21 produtos e 4 sistemas agroindustriais analisados por Fehér \& Papp (2002), sob a ótica de integração à União Européia. A respeito do leite e derivados, o trabalho concluiu que aquele país não é competitivo na produção de leite em pó, leite pasteurizado e queijos. É competitivo em manteiga e cremes, quando comparado com os países que compõem a UE. Isso se daria em função das condições vigentes naquele bloco econômico, em razão aos subsídios dados. Com a adesão da Hungria na UE, o 
SAG do leite daquele país passaria a ser plenamente competitivo, pois poderia contar com os recursos (subsídios e vantagens) advindos da Política Agrícola Comum.

No Brasil, a Embrapa e a Fundação Getúlio Vargas/RJ desenvolveram estudos para cadeias de 11 produtos. No caso do leite, Calegar et al. (2001), Martins (2001) e Tupy (2001) estudaram distintos corredores. Foram considerados três níveis tecnológicos. Calegar et al. (2001) estudaram o corredor de leite em pó de Piracanjuba-GO até São Paulo-SP. Os resultados obtidos demonstraram que todos os estratos eram competitivos e penalizados por politicas públicas, que distorciam o seu desempenho. Martins (2001), ao analisar o corredor de leite em pó de Sete Lagoas-MG até São Paulo-SP, concluiu de maneira semelhante. A penalização foi maior quanto maior o nível tecnológico adotado. Tupy (2001) considerou o corredor de leite B de São José dos Campos-SP até São Paulo-SP. Os coeficientes técnicos usados foram obtidos na literatura. $O$ autor concluiu que todos os três níveis tecnológicos foram penalizados com políticas públicas, mas esta penalização foi maior quanto menor o nível tecnológico adotado.

Estudo realizado por Alves (2002), para quatro corredores da manga no nordeste, concluiu que esse produto apresenta eficiência e competitividade na exportação.

\subsection{Metodologia}

Os dados de custo de produção das propriedades, bem como os procedimentos adotados foram descritos no capítulo anterior.

As planilhas de custo de processamento foram elaboradas por técnico do Instituto de Laticínios Cândido Tostes, da Empresa de Pesquisa Agropecuária de Minas Gerais - Epamig. Passaram por validação de técnicos de duas das cinco maiores empresas de laticínios do mercado brasileiro. Para 
cada corredor simularam-se duas plantas industriais: leite Longa Vida e Leite em Pó, com processamento de um milhão de litros de leite/dia.

Foram processadas 170 Matrizes de Análise Política, a saber: uma para cada propriedade e duas para cada corredor, considerando-se a cadeia produtiva do leite Longa Vida e a cadeia produtiva do Leite em Pó. Foi utilizado o software desenvolvido com essa finalidade pela Secretaria de Assuntos Estratégicos da Embrapa. Os fatores de conversão necessários para a obtenção dos preços sociais foram aqueles disponíveis no software, reajustados em função da variação cambial.

Para a conversão da moeda internacional em moeda nacional nas Matrizes de Análise Política, foi utilizado a taxa social de câmbio de equilíbrio para 2000, proposta por Ferreira (2002), que foi de $R \$ 2,1142=$ US $\$ 1,00$.

Procederam-se simulações em relação ao impacto esperado na eficiência e na competitividade, o que foi feito por indicadores Razão do Custo Doméstico - RCD e Razão do Custo Privado - RCP, extraídos das matrizes construídas para cada um dos dez corredores e para cada cadeia produtiva: leite em pó e leite longa vida. Para simulações de eficiência, considerou-se o indicador RCD e as variáveis foram aferidas a preços sociais. Para competitividade, o indicador foi RCP, com preços de mercado doméstico. As variáveis e as respectivas formulações, para simulações quanto ao impacto na eficiência e na competitividade, foram as que seguem.

a) Mão-de-Obra Não Qualificada:

$$
M N Q=\left\{\left\{\left[\left(\frac{x_{i j}+\delta_{i j} * 0,01}{\left(\gamma_{i j}-\varphi_{i j}\right)}\right)\right] \frac{1}{\rho_{i j}}\right\}-1\right\} * 100
$$

em que: $\chi_{i j}=$ custo dos fatores de produção na $i$-ésima cadeia produtiva do $j$ ésimo corredor; $\delta_{i j}=$ custo do trabalho não qualificado na $i$-ésima cadeia 
produtiva do $j$-ésimo corredor; $\gamma_{i j}=$ receita na $i$-ésima cadeia produtiva do $j$ ésimo corredor; $\varphi_{i j}=$ custo de insumos transacionáveis na $i$-ésima cadeia produtiva do $j$-ésimo corredor; $\rho_{i j}=$ indicador RCD ou indicador RCP na $i$-ésima cadeia produtiva do $j$-ésimo corredor ; $i=$ cadeia produtiva Leite Longa Vida, cadeia produtiva Leite em Pó; e $j=1, \ldots, 10$.

b) Mão-de Obra Qualificada:

$$
M Q=\left\{\left\{\left[\left(\frac{x_{i j}+Z_{i j} * 0,01}{\left(\gamma_{i j}-\varphi_{i j}\right)}\right)\right] \frac{1}{\rho_{i j}}\right\}-1\right\} * 100
$$

em que $Z_{i j}=$ custo do trabalho qualificado na $i$-ésima cadeia produtiva no $j$ ésimo corredor.

c) Capital:

$$
\left.C=\left\{\int\left[\left(\frac{x_{i j}+\mathrm{K}_{i j} * 0,01}{\left(\gamma_{i j}-\varphi_{i j}\right)}\right)\right] \frac{1}{\rho_{i j}}\right\}-1\right\} * 100
$$

em que $\kappa_{i j}=$ custo do capital na $i$-ésima cadeia produtiva no $j$-ésimo corredor .

d) Valor do Produto :

$$
V P=\left\{\left\{\left[\frac{\left(x_{i j}\right)}{\left(\gamma_{i j} * 1,01-\varphi_{i j}\right.}\right] \frac{1}{\rho_{i j}}\right\}-1\right\} * 100
$$

e) Produtividade:

$$
P=\left\{\left[\left(\frac{\frac{\theta_{i j}}{\zeta_{i j}{ }^{*} 1,01}}{\gamma_{i j}-\frac{\beta_{i j}}{1,01+\delta_{i j}}}\right) \frac{1}{\rho_{i j}}\right]-1\right\} * 100
$$


em que: $\theta_{i j}=$ Custo de Fatores de Produção ao nível das propriedades na $i$ ésima cadeia produtiva do $j$-ésimo corredor; $\zeta_{i j}=$ Custo de Fatores de Produção pós-propriedades na $i$-ésima cadeia produtiva do $j$-ésimo corredor $\beta_{i j}=$ Custo de insumos transacionáveis nível das propriedades na $i$-ésima cadeia produtiva do j-ésimo corredor; $\delta_{i j}=$ Custo de insumos transacionáveis pós-propriedades na $i$ ésima cadeia produtiva do $j$-ésimo corredor .

f) Valor para que a cadeia tenha Lucro Zero:

$$
L_{0}=\gamma_{i j}-\sigma_{i j}
$$

em que $\sigma_{i j}=$ Lucro da cadeia na $i$-ésima cadeia produtiva do $j$-ésimo corredor.

\subsection{Resultados da MAP}

\subsubsection{Propriedades leiteiras}

Pela metodologia da MAP, a análise de competitividade é feita comparando custos dos insumos e fatores de produção e preço do leite recebido pelos produtores, em termos de mercado interno. São consideradas propriedades competitivas aquelas que apresentem lucro privado positivo. Os resultados obtidos são apresentados no Anexo A, para todas as 150 propriedades formadoras dos dez corredores, em tabelas que retratam 0 desempenho econômico.

Por outro lado, a eficiência ou vantagem comparativa é feita também com base no cálculo de custos e receita das propriedades, contudo, tomandose como referência os preços de insumos e do leite em termos de mercado internacional. Aos fatores de produção não transacionáveis são atribuídos respectivos preços-sombra. São consideradas propriedades eficientes aquelas que apresentem lucro social positivo. 
Todas as 150 propriedades, foram eficientes, mesmo as que não foram competitivas. O resultado encontrado para esse e outros indicadores, por propriedade, são apresentados no Anexo C. A perda de competitividade se deveu à divergências impostas por políticas públicas e por falhas de mercado, o que fez com que a receita auferida pelas propriedades analisadas tenha sido inferior àquela que seria obtida, caso pudessem conduzir seus sistemas de produção a preços em que a atuação de políticas de governo fossem neutras e na inexistência de falhas de mercado.

A Tabela 27 retrata indicadores médios obtidos para as propriedades que participam dos corredores estudados. O lucro social médio por mil litros de leite foi positivo em todos os corredores. Por serem sistemas de produção eficientes, não há ganho social com importações de leite. As propriedades que formam os corredores do estado de São Paulo foram as que apresentaram menores lucros sociais médios ( $R \$ 167,00$ e $R \$ 173,00$ por mil litros).

Tabela 27. Indicadores privados e sociais de propriedades leiteiras por litro de leite, por corredor.

\begin{tabular}{rcccccccc}
\hline Corredor & $\begin{array}{c}\text { Lucro } \\
\text { Social } \\
\text { (R\$) }\end{array}$ & $\begin{array}{c}\text { Razão } \\
\text { Custo } \\
\text { Privado }\end{array}$ & $\begin{array}{c}\text { Custo } \\
\text { Rec. } \\
\text { Dom. }\end{array}$ & $\begin{array}{c}\text { Transf. } \\
\text { Líq. Pol. } \\
(\mathrm{R} \$)\end{array}$ & $\begin{array}{c}\text { Coef. } \\
\text { Prot. } \\
\text { Nom. }\end{array}$ & $\begin{array}{c}\text { Coef. } \\
\text { Prot. } \\
\text { Efet. }\end{array}$ & $\begin{array}{c}\text { Coef. } \\
\text { Lucrat. }\end{array}$ & $\begin{array}{c}\text { Des. } \\
\text { Agent. }\end{array}$ \\
\hline Piracanjuba & 230 & 0,04 & 0,29 & $-0,18$ & 0,65 & 0,46 & 0,17 & $-0,36$ \\
Rio Verde & 248 & 0,12 & 0,25 & $-0,20$ & 0,61 & 0,40 & 0,17 & $-0,39$ \\
Ibiá & 237 & 0,02 & 0,22 & $-0,13$ & 0,75 & 0,59 & 0,45 & $-0,26$ \\
S. Lagoas & 221 & 0,06 & 0,24 & $-0,14$ & 0,72 & 0,50 & 0,31 & $-0,28$ \\
Jundiaí & 167 & 0,82 & 0,38 & $-0,12$ & 0,74 & 0,53 & 0,16 & $-0,25$ \\
Rib. Preto & 173 & 0,08 & 0,33 & $-0,13$ & 0,74 & 0,48 & 0,14 & $-0,27$ \\
Castro & 263 & 0,08 & 0,19 & $-0,15$ & 0,70 & 0,53 & 0,40 & $-0,30$ \\
Mal. Rond. & 253 & 0,10 & 0,21 & $-0,20$ & 0,59 & 0,36 & 0,18 & $-0,40$ \\
Teutônia & 283 & 0,39 & 0,16 & $-0,19$ & 0,62 & 0,43 & 0,31 & $-0,38$ \\
Carazinho & 258 & 0,05 & 0,20 & $-0,19$ & 0,62 & 0,41 & 0,26 & $-0,37$ \\
\hline
\end{tabular}

Fonte: Dados da pesquisa 
Um segundo grupo intermediário foi encontrado nos corredores de Minas Gerais ( $R \$ 221,00$ e $R \$ 237,00$ ) e Goiás ( $R \$ 230,00$ e $R \$ 248,00$ ). Os corredores com propriedades mais eficientes foram encontrados no sul do país, com destaque para Castro $(R \$ 263,00)$ e Teutônia $(R \$ 283,00)$.

A Razão do Custo Privado - RCP é um indicador de competitividade. Difere, porém, do indicador Lucro Privado, por medir a participação do custo dos fatores na receita, desconsiderando-se o custo dos insumos transacionáveis, em termos de preços privados. Valores menores que à unidade indicam que o sistema é competitivo, fato ocorrido em todos os corredores. Ibiá $(0,02)$, Piracanjuba $(0,04)$, Carazinho $(0,05)$ e Sete Lagoas $(0,06)$ foram os corredores em que os fatores de produção apresentaram maiores retornos, enquanto que Jundiaí $(0,82)$ foi o corredor menos competitivo.

O indicador Custo dos Recursos Domésticos - CRD assemelha-se à $\mathrm{RCP}$, diferindo por ser aferido em preços sociais e, portanto, retrata eficiência. Todos os corredores mostraram-se eficientes. Os melhores desempenhos foram obtidos pelos estados do sul, enquanto que os menos eficientes foram os corredores de São Paulo.

Por focar fatores de produção, os indicadores podem ser analisados sob a ótica de valor adicionado. Os resultados obtidos permitem afirmar que, embora com magnitudes diferentes, em todos os corredores os fatores apresentaram retornos que sinalizam a expansão da atividade, pois adicionam à receita proporcionalmente mais do que adicionam ao custo. $\mathrm{Na}$ aferição em termos de preços privados - RCP, a atividade de produção de leite pode absorver fatores de outras atividades econômicas enquanto, em termos sociais - CRD, há ganhos com a expansão, em razão do retorno obtido com os fatores poupar divisas internacionais.

O indicador Transferência Líquida de Políticas - TLP estima o quanto as divergências retiraram do lucro das propriedades, em valores monetários, 
transferindo-os para outros setores da sociedade, quando os valores são negativos. Considera, portanto, o efeito de políticas e falhas de mercado sobre o preço do leite e sobre os custos dos insumos transacionáveis e dos fatores.

Todos os corredores demonstraram ter ocorrido transferências da produção primária de leite para demais setores. Medidas em mil litros de leite, as maiores transferências ocorreram, em Mal. Cândido Rondon (R\$ 204,00 por mil litros) e nos estados de Goiás (R\$198,00 e R\$181,00) e Rio Grande do Sul $(R \$ 192,00$ e $R \$ 186,00)$. As menores deram-se nos estados de São Paulo ( $R$ \$ $118,00$ e $R \$ 134,00)$ e Minas Gerais $(R \$ 127,00$ e $R \$ 144,00)$.

A divergência entre os preços internos e os preços mundiais praticados, mesmos que estes sejam subsidiados, foram desfavoráveis aos produtores, o que levou a uma desproteção da atividade. O Coeficiente de Proteção Nominal - CPN demonstrou que as políticas de governo e as falhas de mercado fizeram com que o preço recebido pelos produtores correspondesse a $59 \%$ e $75 \%$ daqueles do mercado internacional. Quando considerados em conjunto o preço do leite recebido pelos produtores e os preços dos insumos transacionáveis, em termos de mercado interno e mercado internacional, que é dado pelo Coeficiente de Proteção Efetiva - CPE, verificou-se que as propriedades estiveram ainda mais desprotegidas, pois os valores obtidos corresponderam a preços entre $36 \%$ e $53 \%$ dos preços internacionais. A desproteção ou taxação, nos dois indicadores, foi maior em Mal. Cândido Rondon, Rio Verde, Teutônia e Carazinho. Foi menor em lbiá e nos corredores de São Paulo para CPN, e nos corredores de Minas Gerais, Castro e Jundiaí para CPE.

O Coeficiente de Lucratividade - CL é uma razão entre o lucro privado e o lucro social que, dessa forma, mede o quanto o primeiro distanciase do segundo, em função de distorções. O indicador CPE ignora os efeitos de transferência de políticas no mercado de fatores e não é um indicador completo 
de incentivos. Com efeito, o CL é uma extensão do CPE, por incluir transferência de fatores. Todos os corredores apresentaram valores inferiores à unidade, o que traduz em taxação da atividade. Ribeirão Preto $(0,14)$ e Ibiá $(0,45)$ foram os corredores com maior e menor penalização, respectivamente.

O indicador Taxa de Desestímulo aos Agentes - DA demonstrou que as propriedades de todos os corredores receberam desestímulo. Mal. Cândido Rondon e os corredores do Rio Grande do Sul e de Goiás foram os que apresentaram maiores taxas de desestímulo, contra os de Minas Gerais e São Paulo, os menores.

\subsubsection{Leite Longa Vida}

A Tabela 28 reproduz indicadores extraídos da MAP, para cada corredor. As matrizes encontram-se no Anexo D. Todos os corredores mostraram-se competitivos, pois apresentaram lucros privados, medidos a preços de mercado interno. O corredor Castro ( $R \$ 0,277$ por litro) foi o de melhor desempenho, seguido dos corredores do Rio Grande do Sul $(\mathrm{R} \$ 0,252$ e $\mathrm{R} \$ 0,246$ por litro) e Rio Verde ( $\mathrm{R} \$ 0,240$ por litro). Os corredores de São Paulo ( $R$ 0,179 e $R \$ 0,194$ por litro) e Sete Lagoas ( $R \$ 0,193$ por litro) foram os menos competitivos.

Por outro lado, todos os corredores mostraram-se eficientes. Novamente, os corredores com melhor desempenho foram Castro, Rio Grande do Sul e Rio Verde. Os corredores menos eficientes também foram os de São Paulo e Sete Lagoas.

Numa comparação entre lucros privados e lucros sociais, percebe-se que todos os corredores apresentaram distorções negativas, demonstrando que as políticas públicas e as falhas de mercado diminuíram o lucro auferido na cadeia do leite Longa Vida. As maiores distorções foram nos corredores Teutônia, Mal. Cândido Rondon e Piracanjuba, enquanto as menores ocorreram 
em São Paulo e Castro. Jundiaí apresentou distorção restrita e bem inferior aos demais corredores $(R \$ 0,002)$.

Tabela 28. Indicadores privados e sociais da cadeia produtiva do leite Longa Vida, por corredor.

\begin{tabular}{lccccccc}
\hline Corredores & $\begin{array}{c}\text { Lucro } \\
\text { Priv. } \\
(\mathrm{R} \$)\end{array}$ & $\begin{array}{c}\text { Lucro } \\
\text { Social } \\
(\mathrm{R} \$)\end{array}$ & $\begin{array}{c}\text { Trans. } \\
\text { Líq. } \\
(\mathrm{R} \$)\end{array}$ & $\begin{array}{c}\text { Coef. } \\
\text { Prot. } \\
\text { Nom. }\end{array}$ & $\begin{array}{c}\text { Coef. } \\
\text { Prot. } \\
\text { Efet. }\end{array}$ & $\begin{array}{c}\text { Coef. } \\
\text { Lucrat. }\end{array}$ & $\begin{array}{c}\text { Deses. } \\
\text { Agen. }\end{array}$ \\
\hline Piracanjuba & 0,211 & 0,248 & $-0,038$ & 0,96 & 0,91 & 0,85 & $-0,05$ \\
Rio Verde & 0,240 & 0,272 & $-0,034$ & 0,96 & 0,92 & 0,88 & $-0,04$ \\
Ibiá & 0,220 & 0,240 & $-0,021$ & 0,98 & 0,95 & 0,91 & $-0,03$ \\
Sete. Lagoas & 0,193 & 0,220 & $-0,027$ & 0,97 & 0,92 & 0,88 & $-0,03$ \\
Jundiaí & 0,194 & 0,192 & 0,002 & 1,00 & 1,04 & 1,01 & 0,00 \\
Ribirão. Preto & 0,179 & 0,192 & $-0,014$ & 0,99 & 0,99 & 0,93 & $-0,02$ \\
Castro & 0,277 & 0,295 & $-0,019$ & 0,98 & 0,96 & 0,94 & $-0,02$ \\
Mal. Cândido Rondon & 0,227 & 0,264 & $-0,036$ & 0,96 & 0,90 & 0,86 & $-0,04$ \\
Teutônia & 0,252 & 0,295 & $-0,042$ & 0,95 & 0,89 & 0,86 & $-0,05$ \\
Carazinho & 0,246 & 0,277 & $-0,043$ & 0,96 & 0,91 & 0,85 & $-0,05$ \\
\hline
\end{tabular}

Fonte: Dados da pesquisa

O indicador Transferência Líquida, ao considerar o efeito de políticas e falhas de mercado sobre o produto e os insumos, demonstrou que foram transferidos de $R \$ 0,02$ a $R \$ 0,06$ por litro de leite longa vida produzido, dos corredores para outros setores da economia. Uma exceção ocorreu em relação ao corredor Jundiaí, que recebeu transferência do restante da economia, embora tenha sido um valor desprezível $(R \$ 0,002)$. Quanto aos demais, as maiores transferências se deram nos corredores do Rio Grande do Sul, de Goiás e Mal. Cândido Rondon, enquanto os menos penalizados foram os de Ribeirão Preto e Castro.

Os coeficientes de proteção demonstraram que todos os corredores apresentaram niveis reduzidos de desproteção, sendo que o corredor Jundiaí apresentou restrito índice de proteção. O Coeficiente de Proteção Nominal - 
CPN indicou que os preços domésticos de comercialização estiveram muito próximos dos preços mundiais. Resultado semelhante foi obtido para o indicador Coeficiente de Proteção Efetiva - CPE, que considera o efeito de política e falhas de mercado, não somente sobre o preço dos produtos, mas também sobre o preço dos insumos transacionáveis.

Esses indicadores parecem estar em consonância com as importações de Leite Longa Vida ocorridas no periodo analisado, que foram reduzidas. Entre agosto de 2000 e julho de 2001, foram de US $\$ 33$ milhões, o que correspondeu a $8,1 \%$ do total das importações lácteas, de acordo com o Banco de Dados Econômicos da Embrapa Gado de Leite (2001). Em termos de volume, o equivalente a $3,4 \%$ do consumo nacional de Leite Longa Vida em 2.001 .

O indicador Coeficiente de Lucratividade é uma extensão do CPE, por incluir a transferência de fatores. Para o leite Longa Vida, todos os corredores apresentaram taxação líquida, com coeficientes menores que a unidade, exceção do corredor Jundiaí. A taxação ou penalização foi, contudo, restrita. Resultado similar foi obtido para o indicador DA.

O Quadro 7 consolida os custos, lucros e receitas médias, obtidos nos quatro elos considerados, para cada corredor, por 1.000 litros de leite Longa Vida. A apropriação se deu sob a ótica do valor adicionado em cada um dos quatro elos da cadeia produtiva: produção, transporte até a usina, beneficiamento e transporte até São Paulo. Formaram-se três faixas distintas de custos fixos médios. Cinco corredores apresentaram custos entre $R \$ 50,00$ e $R \$ 60,00$, três entre $R \$ 60,00$ e $R \$ 70,00$ e dois tiveram custos fixos acima de $\mathrm{R} \$ 70,00$. Carazinho e Castro consolidaram custos fixos mais baixos, enquanto Jundiaí obteve o custo fixo médio mais elevado. O maior impacto sobre este custo se deu pelo elo produção. 


\begin{tabular}{|c|c|c|c|c|c|c|c|c|c|c|}
\hline \multirow[t]{2}{*}{ Itens } & \multicolumn{2}{|c|}{ Goiás } & \multicolumn{2}{|c|}{$\begin{array}{l}\text { Minas } \\
\text { Gerais }\end{array}$} & \multicolumn{2}{|c|}{ São Paulo } & \multicolumn{2}{|c|}{ Paraná } & \multicolumn{2}{|c|}{$\begin{array}{c}\text { Rio Grande do } \\
\text { Sul }\end{array}$} \\
\hline & $\begin{array}{c}\text { Pira- } \\
\text { canjuba }\end{array}$ & $\begin{array}{l}\text { Ja- } \\
\text { taí }\end{array}$ & Ibiá & $\begin{array}{l}\text { S. La- } \\
\text { goas }\end{array}$ & $\begin{array}{c}\text { Jundi- } \\
\text { ai }\end{array}$ & $\begin{array}{l}\text { Rib. } \\
\text { Preto }\end{array}$ & $\begin{array}{c}\text { Cas- } \\
\text { tro }\end{array}$ & $\begin{array}{r}\text { Mal. } \\
\text { Rond }\end{array}$ & $\begin{array}{l}\text { Teu- } \\
\text { tônia }\end{array}$ & $\begin{array}{l}\text { Cara- } \\
\text { zinho }\end{array}$ \\
\hline C. Fixo & 72 & 68 & 56 & 60 & 73 & 63 & 52 & 53 & 56 & 52 \\
\hline C. Variável & 606 & 600 & 634 & 650 & 563 & 592 & 583 & 630 & 520 & 533 \\
\hline M-de-Obra & 39 & 41 & 37 & 30 & 41 & 35 & 24 & 31 & 24 & 29 \\
\hline $\mathrm{N}-\mathrm{Q}$ & 22 & 23 & 20 & 16 & 24 & 17 & 11 & 17 & 13 & 16 \\
\hline Qualif & 6 & 6 & 6 & 6 & 8 & 9 & 6 & 5 & 5 & 6 \\
\hline Encargos & 11 & 12 & 11 & 8 & 9 & 9 & 7 & 9 & 6 & 7 \\
\hline Insumos & 465 & 441 & 476 & 499 & 479 & 511 & 437 & 477 & 453 & 462 \\
\hline Emb & 255 & 25 & 25 & 255 & 25 & 255 & 255 & 25 & 255 & 255 \\
\hline Out. & 210 & 188 & 221 & 244 & 224 & 257 & 182 & 222 & 198 & 207 \\
\hline Impostos & 99 & 116 & 119 & 119 & 35 & 37 & 117 & 117 & 40 & 37 \\
\hline Outros & 3 & 2 & 2 & 2 & 8 & 9 & 5 & 5 & 3 & 5 \\
\hline C. Total & 678 & 668 & 690 & 710 & 636 & 655 & 635 & 683 & 576 & 585 \\
\hline Receita & 788 & 788 & 788 & 788 & 788 & 788 & 788 & 788 & 788 & 788 \\
\hline Lucro & 110 & 120 & 98 & 78 & 152 & 133 & 153 & 105 & 212 & 203 \\
\hline
\end{tabular}

Quadro 7 - Custos consolidados, receita e lucro da cadeia produtiva do Leite Longa Vida, por mil litros, por corredor, Agosto/2000 a Julho/2001 $(R \$ 1,00)$.

Fonte: Dados da Pesquisa

O custo variável entre os corredores esteve entre $R \$ 520,00$ (Teutônia) a $\mathrm{R} \$ 650,00$ por mil litros de leite (Sete Lagoas). Um importante item responsável por essa variação foi a política de ICMS adotada pelos estados. Em Minas Gerais a alíquota foi de $12 \%$, enquanto em São Paulo e no Rio Grande do Sul o leite Longa Vida teve isenção. Em geral, os impostos representaram entre $12 \%$ a $15 \%$ da receita nos corredores, ao longo da cadeia, à exceção dos estados citados. Não foram incluídos neste cálculo os impostos incidentes sobre os insumos consumidos no primeiro elo. Por não permitirem diferimento, é de se supor, portanto, que a carga tributária seja maior que a encontrada.

Quanto ao custo médio da mão-de-obra, sua participação percentual variou entre $3,1 \%$ e $5,2 \%$ da receita, incluindo os encargos sociais. Esse item 
onerou o custo menos que o custo do capital fixo e os impostos. Exceção para os corredores de São Paulo.

$O$ item que se destacou, contudo, foi a embalagem cartonada do leite Longa Vida. A metade de todos os custos variáveis foi atribuída a esse item e correspondeu a cerca de $1 / 3$ da receita. A embalagem custou mais que todo o capital fixo, somado aos custos de mão-de-obra e impostos incidentes em todos os quatro elos da cadeia. Juntos, esses itens representaram, em média, cerca de $80 \%$ do custo da embalagem. O conjunto de impostos e embalagem, em média, onerou em mais da metade os custos totais consolidados na cadeia.

Os menores custos totais médios acumulados foram registrados nos corredores do Rio Grande do Sul, com desempenho significativamente mais favorável que os demais. Castro foi o corredor com maior capital imobilizado de todos, em termos absolutos. Os elevados níveis de produção e produtividade, contudo, foram responsáveis pela redução do custo total. O corredor Jundiaí, cujas propriedades não tiveram bom nivel de eficiência produtiva, teve a seu favor a isenção de ICMS e a proximidade de São Paulo, o que fez diminuir o custo de frete. Além disso, o preço da terra em Jundiaí, não era tão elevado como nos estados do sul. Ribeirão Preto contou com esses fatores favoráveis, excetuando-se o preço da terra. Já Teutônia e Carazinho deveram seu bom desempenho à produtividade das fazendas e à não incidência de ICMS. A isenção desse imposto viabilizou os custos de frete até São Paulo.

Os corredores dos estados de Minas Gerais tiveram elevados custos, devido ao ICMS e ao preço ao produtor relativamente alto, o que fez com que o lucro super normal do elo processamento fosse pequeno em Sete Lagoas ( $R \$ 2,00 /$. $)$ e nulo em Ibiá.

Os corredores do Rio Grande do Sul foram os de melhor desempenho econômico, seguidos de Jundiaí, Castro e Ribeirão Preto. 
Os corredores Jataí e Piracanjuba, colocaram-se em posição intermediária em termos de lucros. Os baixos índices de produtividade e a incidência de impostos em Goiás auxiliam na explicação desse comportamento. É relevante registrar, contudo, que não se considerou a ação do Fundo Constitucional do Centro-Oeste - FCO sobre as propriedades e a planta industrial.

\subsubsection{Leite em pó}

A Tabela 29 retrata indicadores obtidos para os corredores extraídos das respectivas Matrizes de Análise Política, que se encontram no Anexo D. Todos os corredores apresentaram lucros privados na produção de leite em pó, e foram, portanto, competitivos. Castro, Teutônia e Carazinho foram os corredores com melhor desempenho, enquanto os corredores de São Paulo e Sete Lagoas colocaram-se em posição inferior. Ademais, todos os corredores apresentaram Lucro Social, ou seja, todos foram eficientes. Nesse contexto, Castro e os corredores do Rio Grande do Sul são cadeias produtivas para Leite em Pó mais eficientes.

Tabela 29. Indicadores privados e sociais da cadeia produtiva do leite em Pó, por corredor.

\begin{tabular}{lccccccc}
\hline Corredores & $\begin{array}{c}\text { Lucro } \\
\text { Priv. } \\
\text { (R\$) }\end{array}$ & $\begin{array}{c}\text { Lucro } \\
\text { Social } \\
\text { (R\$) }\end{array}$ & $\begin{array}{c}\text { Trans. } \\
\text { Líq. } \\
\text { (R\$) }\end{array}$ & $\begin{array}{c}\text { Coef. } \\
\text { Prot. } \\
\text { Nom. }\end{array}$ & $\begin{array}{c}\text { Coef. } \\
\text { Prot. } \\
\text { Efet. }\end{array}$ & $\begin{array}{c}\text { Coef. } \\
\text { Lucrat. }\end{array}$ & $\begin{array}{c}\text { Valor } \\
\text { Comp. } \\
\text { (R\$) }\end{array}$ \\
\hline Piracanjuba & 2,08 & 5,60 & $-3,52$ & 0,63 & 0,48 & 0,37 & $-0,38$ \\
Rio Verde & 2,41 & 5,91 & $-3,50$ & 0,63 & 0,50 & 0,41 & $-0,37$ \\
Ibiá & 2,12 & 5,65 & $-3,53$ & 0,63 & 0,47 & 0,38 & $-0,38$ \\
Sete Lagoas & 1,80 & 5,27 & $-3,47$ & 0,63 & 0,44 & 0,34 & $-0,37$ \\
Jundiaí & 1,70 & 5,19 & $-3,49$ & 0,63 & 0,46 & 0,33 & $-0,37$ \\
Ribeirão Preto & 1,57 & 5,16 & $-3,49$ & 0,63 & 0,43 & 0,30 & $-0,37$ \\
Castro & 2,79 & 6,33 & $-3,54$ & 0,63 & 0,50 & 0,44 & $-0,38$ \\
Mal. Rondon & 2,29 & 5,82 & $-3,53$ & 0,63 & 0,47 & 0,39 & $-0,38$ \\
Teutônia & 2,59 & 6,11 & $-3,52$ & 0,63 & 0,49 & 0,42 & $-0,38$ \\
Carazinho & 2,49 & 5,98 & $-3,49$ & 0,63 & 0,48 & 0,42 & $-0,37$ \\
\hline
\end{tabular}

Fonte: Dados da pesquisa 
Pelo efeito de politicas públicas e falhas de mercado, foram subtraídos de $R \$ 3,49$ a $R \$ 3,54$ por quilo de leite em pó produzido e entregue em São Paulo, de acordo com o indicador TLP. Em todos os corredores ocorreu transferências líquidas negativas.

Em relação aos indicadores de proteção, CPN e CPE demonstraram que as cadeias dos diferentes corredores estiveram desprotegidas em relação ao produto importado - CPN, e no conjunto de insumos transacionáveis e produto importado - CPE. Considerando-se o indicador CPE, o corredor Ribeirão Preto foi aquele em que a cadeia produtiva do Leite em Pó mostrou-se mais desprotegida. A magnitude de desproteção entre os corredores, todavia, apresentou pouca variação entre os corredores.

Os indicadores Coeficiente de Lucratividade e Taxa de Desestímulo aos Agentes também confirmaram a condição de penalização da cadeia, em todos os corredores, por políticas públicas e falhas de mercado. Ribeirão Preto e Castro foram os corredores com maior e menor penalização, respectivamente, pelo indicador $\mathrm{CL}$. Não houve, entretanto, grandes variações entre os corredores em relação aos resultados obtidos para os indicadores citados.

O Quadro 8 apresenta custos, receitas e lucros da cadeia produtiva do Leite em Pó para todos os corredores. Em relação ao custo total, o custo fixo variou entre 11,2\% (Mal. Cândido Rondon), e 17,4\% (Jundiaí). Em termos absolutos, os corredores Mal. Cândido Rondon, Teutônia e Castro obtiveram os menores custos fixos por tonelada de Leite em Pó entregue em São Paulo, enquanto Jundiaí e Piracanjuba apresentaram os maiores. 


\begin{tabular}{|c|c|c|c|c|c|c|c|c|c|c|}
\hline \multirow[t]{2}{*}{ Itens } & \multicolumn{2}{|c|}{ Goiás } & \multicolumn{2}{|c|}{$\begin{array}{l}\text { Minas } \\
\text { Gerais }\end{array}$} & \multicolumn{2}{|c|}{ São Paulo } & \multicolumn{2}{|c|}{ Paraná } & \multicolumn{2}{|c|}{$\begin{array}{c}\text { Rio Grande } \\
\text { do Sul }\end{array}$} \\
\hline & $\begin{array}{c}\text { Piracan } \\
\text { juba }\end{array}$ & Jataí & & $\begin{array}{l}\text { S. La- } \\
\text { goas }\end{array}$ & $\begin{array}{c}\text { Jundi- } \\
\text { aí }\end{array}$ & $\begin{array}{l}\text { Rib. } \\
\text { Preto }\end{array}$ & $\begin{array}{c}\text { Cas- } \\
\text { tro }\end{array}$ & $\begin{array}{l}\text { Mal. } \\
\text { Rond. }\end{array}$ & $\begin{array}{l}\text { Teu- } \\
\text { tônia }\end{array}$ & $\begin{array}{c}\text { Caraz } \\
\text { inho } \\
\end{array}$ \\
\hline Fixo & 75 & 65 & 57 & 61 & 79 & 66 & 52 & 51 & 55 & 51 \\
\hline Variável & 385 & 361 & 413 & 452 & 376 & 405 & 354 & 404 & 305 & 323 \\
\hline M-de-Obra & 38 & 40 & 37 & 38 & 45 & 35 & 22 & 29 & 22 & 27 \\
\hline N-Qualif. & 26 & 26 & 23 & 18 & 28 & 19 & 12 & 21 & 16 & 18 \\
\hline Qualif. & 3 & 03 & 4 & 14 & 8 & 8 & 4 & 2 & 2 & 4 \\
\hline Encargos & 9 & 11 & 10 & 6 & 9 & 8 & 6 & 6 & 4 & 5 \\
\hline Insumos & 267 & 241 & 281 & 319 & 292 & 327 & 235 & 278 & 250 & 260 \\
\hline Outros & 2 & 2 & 1 & 2 & 10 & 11 & 5 & 5 & 4 & 6 \\
\hline Impostos & 78 & 78 & 94 & 93 & 29 & 32 & 92 & 92 & 29 & 30 \\
\hline C. Total & 460 & 426 & 470 & 513 & 455 & 471 & 406 & 455 & 360 & 374 \\
\hline Lucro & 128 & 162 & 118 & 75 & 133 & 117 & 182 & 133 & 228 & 214 \\
\hline Receita & 588 & 588 & 588 & 588 & 588 & 588 & 588 & 588 & 588 & 588 \\
\hline
\end{tabular}

Quadro 8 - Custos consolidados, receita e lucro da cadeia produtiva do Leite em Pó, por 1.000 litros, por corredor., Agosto/2000 a Julho/2001 (R\$ $1,00)$.

Fonte: Dados da pesquisa

O custo variável médio foi menor em Teutônia e maior em Sete Lagoas, em termos absolutos. Em relação ao custo total médio, os corredores Jundiaí e Mal. Cândido Rondon, apresentaram o maior e o menor valores. A aquisição de insumos foi o item que mais onerou a produção, e correspondeu entre $56 \%$ e $70 \%$ do custo total médio. Os corredores Ribeirão Preto e Sete Lagoas foram os que apresentaram os maiores valores, ao passo que Castro obteve o menor. Em relação ao custo total o peso dos impostos variou entre $16 \%$ e $22 \%$ em seis corredores e entre $6 \%$ e $8 \%$ nos estados de São Paulo e Rio Grande do Sul. Em todos os estados a remuneração da mão-de-obra empregada em toda a cadeia foi inferior ao ônus representado pelos impostos.

Os corredores do Rio Grande do Sul foram os que apresentaram os maiores lucros. Contribuiu para esse desempenho a isenção de ICMS naquele estado e a produtividade obtida nas propriedades. Isso mais do que 
compensou os custos de transporte até São Paulo. Também o corredor Castro apresentou desempenho favorável, em função da produção e produtividade das propriedades, bem como o baixo custo de frete até o processamento. Caso houvesse isenção de ICMS também no Paraná, esse corredor teria o menor custo de produção entre todos, pois tem a seu favor a proximidade de São Paulo. Nessa situação hipotética, o corredor Mal. Cândido Rondon melhoraria seu desempenho em termos do lucro obtido na cadeia, mas não na mesma magnitude de Castro, face ao custo do frete de captação e de translado do produto até São Paulo. Nos dois casos - captação e distribuição, as distâncias percorridas são desfavoráveis nesse corredor.

Os corredores de Goiás obtiveram posição intermediária, enquanto São Paulo valeu-se da proximidade de São Paulo e da isenção de ICMS para viabilizar a cadeia produtiva do Leite em pó. O menos favorável desempenho dos corredores se deu em Minas Gerais. O elevado preço do leite no primeiro elo em relação aos demais corredores, somado ao ICMS, contribuem para explicar esse comportamento.

\subsubsection{Análise de sensibilidade}

As figuras 20 e 21 reproduzem a consolidação dos lucros auferidos nas cadeias produtivas de Leite Longa Vida e Leite em Pó para os dez corredores, e a partição entre produtores e demais elos das respectivas cadeias (frete até a usina, processamento, frete até São Paulo). Os dados que deram origem às figuras encontram-se no Anexo $E$. Nas duas cadeias, os produtores dos corredores de Minas Gerais e Castro foram os que, em termos percentuais, mais se apropriaram de lucros. Na cadeia de Leite Longa Vida, os corredores de São Paulo foram aqueles em que os produtores menos se apropriaram. Para o Leite em Pó, essa condição se deu em Ribeirão Preto, embora o percentual de apropriação tenha apresentado pouca variação entre os corredores, à 
exceção dos corredores de Minas Gerais e Castro. Os resultados obtidos em Ibiá praticamente inviabilizam a produção de leite Longa Vida naquele corredor.

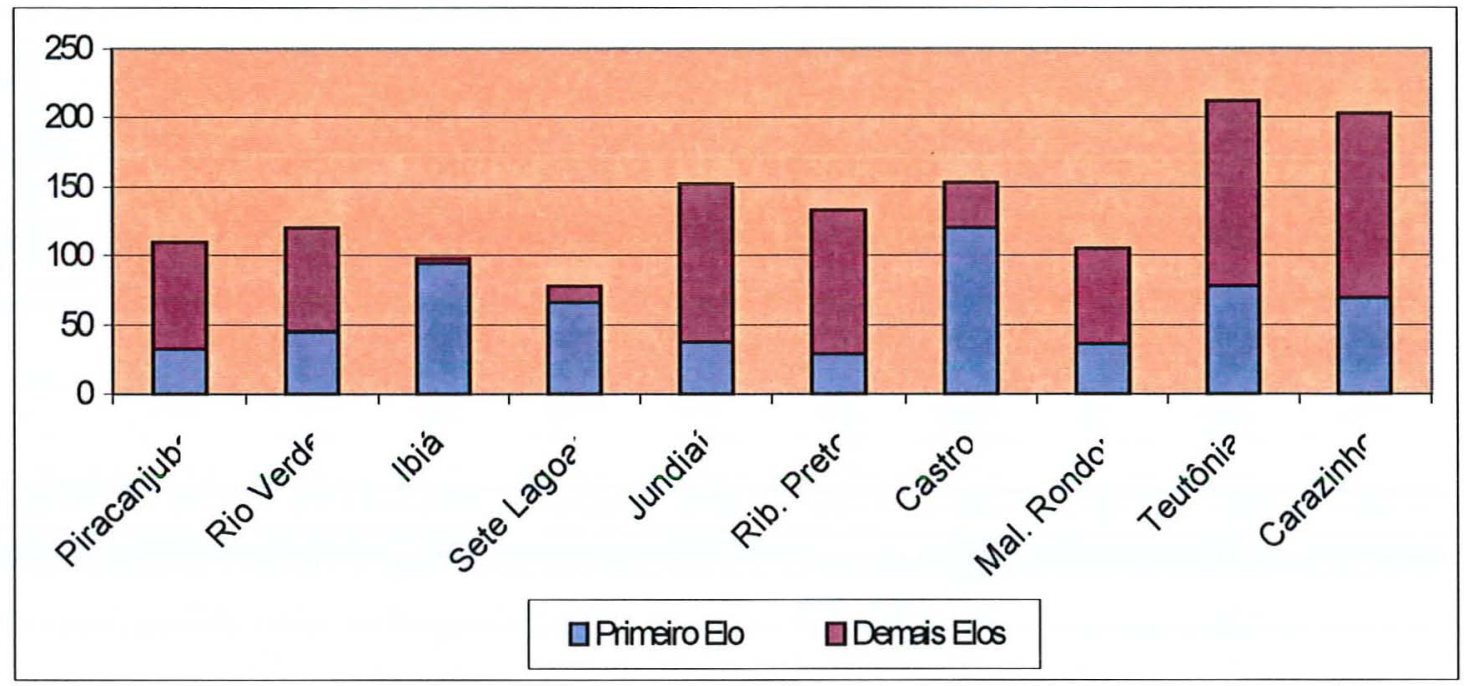

Figura 20 - Lucros consolidados e a partição entre produtores e demais elos da cadeia produtiva do Leite Longa Vida, por mil litros, por corredor.

Fonte: Dados da pesquisa

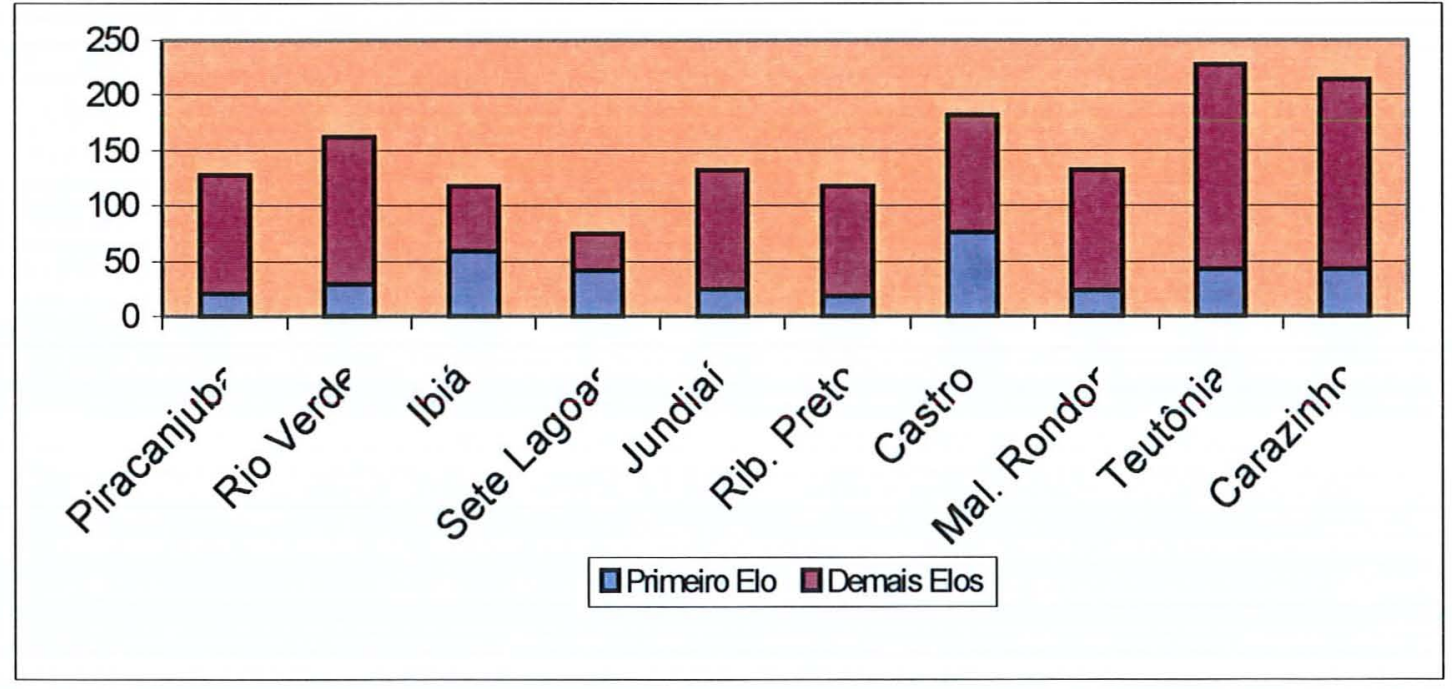

Figura 21 - Lucros consolidados e a partição entre produtores e demais elos da cadeia produtiva do Leite em pó, por mil litros, por corredor.

Fonte: Dados da pesquisa 
As Tabelas 30 e 31 apresentam resultados de simulações por corredor realizadas nas cadeias de leite Longa Vida e Leite em Pó, respectivamente, e relativas ao impacto na eficiência, considerando-se variações no custo dos fatores, no preço do produto e na produtividade. Uma variação em $1 \%$ no custo da mão-de-obra impactaria, em igual sentido, o indicador Razão de Custos Domésticos - RCD, em ambas as cadeias produtivas, embora menos que proporcional à variação. Se o custo da mão-deobra se eleva, haverá redução na eficiência dos corredores. Castro seria o corredor a sofrer o menor impacto para mão-de-obra não qualificada em ambas as cadeias produtivas, enquanto Rio Verde, Ibiá, Jundiaí e Mal. Cândido Rondon sofreriam os maiores impactos na cadeia de Longa Vida e Rio Verde e Mal. Rondon na cadeia de Leite em Pó.

Tabela 30. Variação na Razão do Custo Doméstico da cadeia produtiva do leite Longa Vida, quando ocorre variação de $1 \%$ no valor dos fatores, preço de venda e na produtividade, por corredor.

\begin{tabular}{|c|c|c|c|c|c|}
\hline \multirow[t]{3}{*}{ Corredores } & \multicolumn{3}{|c|}{ Preco Sombra (\%) } & \multirow{3}{*}{$\begin{array}{c}\text { Preço } \\
\text { Leite Longa } \\
\text { Vida }(\%)\end{array}$} & \multirow{3}{*}{$\begin{array}{c}\text { Produti- } \\
\text { Vidade } \\
(\%)\end{array}$} \\
\hline & \multicolumn{2}{|c|}{ Mao-de-obra } & \multirow{2}{*}{ Capital } & & \\
\hline & $\mathrm{N}$-qualif. & Qualif. & & & \\
\hline Piracanjuba & 0,21 & 0,05 & 0,74 & $-2,27$ & $-1,30$ \\
\hline Rio Verde & 0,23 & 0,05 & 0,72 & $-2,17$ & $-1,20$ \\
\hline Ibiá & 0,23 & 0,06 & 0,72 & $-2,40$ & $-1,36$ \\
\hline Sete Lagoas & 0,18 & 0,05 & 0,77 & $-2,60$ & $-1,52$ \\
\hline Jundiai & 0,23 & 0,07 & 0,70 & $-2,56$ & $-1,53$ \\
\hline Rib. Preto & 0,19 & 0,08 & 0,73 & $-2,74$ & $-1,64$ \\
\hline Castro & 0,15 & 0,07 & 0,77 & $-2,15$ & $-1,19$ \\
\hline Mal. Rondon & 0,23 & 0,06 & 0,71 & $-2,33$ & $-1,27$ \\
\hline Teutônia & 0,17 & 0,06 & 0,77 & $-2,17$ & $-1,20$ \\
\hline Carazinho & 0,20 & 0,07 & 0,73 & $-2,24$ & $-1,16$ \\
\hline
\end{tabular}

Fonte: Dados da pesquisa

Nota: Impactos positivos reduzem eficiência 
Tabela 31. Variação na Razão do Custo Doméstico da cadeia produtiva do Leite em Pó quando ocorre variação de $1 \%$ no valor dos fatores, preço de venda e na produtividade, por corredor.

\begin{tabular}{|c|c|c|c|c|c|}
\hline \multirow[t]{3}{*}{ Corredores } & \multicolumn{3}{|c|}{ Preco Sombra (\%) } & \multirow{3}{*}{$\begin{array}{c}\text { Preço } \\
\text { Leite em Pó } \\
(\%)\end{array}$} & \multirow{3}{*}{$\begin{array}{l}\text { Produti- } \\
\text { Vidade } \\
(\%)\end{array}$} \\
\hline & \multicolumn{2}{|c|}{ Mao-de-obra } & \multirow[t]{2}{*}{ Capital } & & \\
\hline & N-qualif. & Qualif. & & & \\
\hline Piracanjuba & 0,24 & 0,02 & 0,74 & $-1,38$ & $-1,23$ \\
\hline Rio Verde & 0,26 & 0,02 & 0,72 & $-1,33$ & $-1,16$ \\
\hline Ibiá & 0,26 & 0,03 & 0,71 & $-1,41$ & $-1,25$ \\
\hline Sete Lagoas & 0,20 & 0,03 & 0,78 & $-1,49$ & $-1,34$ \\
\hline Jundiaí & 0,24 & 0,06 & 0,71 & $-1,44$ & $-1,29$ \\
\hline Rib. Preto & 0,20 & 0,07 & 0,73 & $-1,51$ & $-1,38$ \\
\hline Castro & 0,18 & 0,05 & 0,77 & $-1,32$ & $-1,20$ \\
\hline Mal. Rondon & 0,27 & 0,03 & 0,70 & $-1,40$ & $-1,23$ \\
\hline Teutônia & 0,20 & 0,03 & 0,77 & $-1,34$ & $-1,20$ \\
\hline Carazinho & 0,24 & 0,04 & 0,72 & $-1,36$ & $-1,16$ \\
\hline
\end{tabular}

Fonte: Dados da pesquisa

Nota: Impactos positivos reduzem eficiência

Para mão-de-obra qualificada, Ribeirão Preto foi o corredor com maior sensibilidade em ambas as cadeias. Os corredores Sete Lagoas e os de Goiás foram os de menor sensibilidade para Longa Vida e, novamente, os corredores de Goiás, para Leite em Pó.

Quanto ao fator capital, todos os corredores apresentaram variação em igual sentido, porém menos que proporcionalmente. Embora de magnitude reduzida, as variações de capital foram maiores que as obtidas para o fator trabalho. Os corredores mais sensiveis foram Castro, Sete Lagoas e Teutônia para o Longa Vida e Sete Lagoas para Leite em Pó, enquanto que os menos sensiveis foram Jundiaí, para leite Longa Vida e Mal. Cândido Rondon, para Leite em Pó.

Uma elevação, por hipótese, do preço do leite Longa Vida importado em $1 \%$, motivada por aumento de preços no mercado internacional ou por uma desvalorização na taxa de câmbio, levaria a uma redução mais que 
proporcional do indicador RCD, aumentando a eficiência da cadeia. O inverso se aplica para a hipótese de queda de preços do produto importado. Castro, Rio Verde e Teutônia foram os corredores que apresentaram menor sensibilidade nas duas cadeias produtivas, enquanto os corredores de São Paulo e Minas Gerais foram os mais sensiveis.

Quanto à produtividade, os corredores demonstraram sensibilidade mais que proporcional. Isso significa que um aumento de produtividade impacta sensivel e favoravelmente a eficiência de todos os corredores e cadeias. Os corredores de São Paulo e Minas Gerais foram os mais sensiveis para o Longa Vida, enquanto Ribeirão Preto e Sete Lagoas para o Leite em Pó. Os corredores menos sensiveis foram Castro para Longa Vida e Castro e Rio Verde para Leite em Pó.

Pelas simulações realizadas, a eficiência da cadeia é mais afetada quando ocorrem variações no preço do Leite Longa Vida e Leite em Pó, seguidas por variaçôes na produtividade nessas duas cadeias produtivas. Por outro lado, variações no preço e na mão-de-obra qualificada impactam mais a eficiência do leite Longa Vida, enquanto variações no custo da mão-de-obra qualificada impactam mais a eficiência da cadeia de Leite em Pó. A produtividade impacta a eficiência ligeiramente e em igual sentido o leite Longa Vida, enquanto ambas as cadeias têm sensibilidade semelhante para variações no custo do capital, quanto ao impacto na eficiência.

Simulações sobre competitividade são apresentadas nas Tabelas 32 e 33, para as duas cadeias produtivas e os corredores. Todos os fatores apresentaram capacidade de gerar mudanças menos que proporcional e em igual sentido, no indicador RCP. Isso significa que uma elevação de custos dos fatores de produção elevam aquele indicador, reduzindo a competitividade das cadeias produtivas analisadas. 
Tabela 32. Variação na Razão do Custo Privado da cadeia produtiva do Leite Longa Vida quando ocorre variação de $1 \%$ no valor dos fatores, preço de venda e na produtividade, por corredor.

\begin{tabular}{lccccc}
\hline Corredores & \multicolumn{3}{c}{ Preco Sombra (\%) } & Preço & $\begin{array}{c}\text { Produti- } \\
\text { Mao-de-obra }\end{array}$ \\
& N-qualif. & Qualif. & & $\begin{array}{c}\text { Conga Vida } \\
(\%)\end{array}$ & $(\%)$ \\
\hline Piracanjuba & 0,26 & 0,08 & 0,65 & $-2,39$ & $-1,34$ \\
Rio Verde & 0,29 & 0,09 & 0,62 & $-2,24$ & $-1,22$ \\
lbiá & 0,29 & 0,09 & 0,61 & $-2,45$ & $-1,38$ \\
Sete Lagoas & 0,23 & 0,09 & 0,68 & $-2,73$ & $-1,55$ \\
Jundiaí & 0,27 & 0,10 & 0,63 & $-2,49$ & $-1,47$ \\
Rib. Preto & 0,24 & 0,12 & 0,64 & $-2,77$ & $-1,64$ \\
Castro & 0,19 & 0,11 & 0,69 & $-2,19$ & $-1,21$ \\
Mal. Rondon & 0,27 & 0,11 & 0,62 & $-2,47$ & $-1,32$ \\
Teutônia & 0,19 & 0,12 & 0,69 & $-2,31$ & $-1,22$ \\
Carazinho & 0,22 & 0,13 & 0,64 & $-2,36$ & $-1,22$ \\
\hline
\end{tabular}

Fonte: Dados da pesquisa

Tabela 33. Variação na Razão do Custo Privado da cadeia produtiva do Leite em Pó quando ocorre variação de $1 \%$ no valor dos fatores, preço de venda e na produtividade, por corredor.

\begin{tabular}{|c|c|c|c|c|c|}
\hline \multirow[t]{3}{*}{ Corredores } & \multicolumn{3}{|c|}{ Preco Sombra (\%) } & \multirow{3}{*}{$\begin{array}{c}\text { Preço } \\
\text { Leite em Pó } \\
(\%)\end{array}$} & \multirow{3}{*}{$\begin{array}{l}\text { Produti- } \\
\text { Vidade } \\
(\%)\end{array}$} \\
\hline & Mao-d & -obra & Capital & & \\
\hline & $\mathrm{N}$-qualif. & Qualif. & & & \\
\hline Piracanjuba & 0,30 & 0,04 & 0,66 & $-1,80$ & $-1,60$ \\
\hline Rio Verde & 0,33 & 0,04 & 0,62 & $-1,67$ & $-1,44$ \\
\hline Ibiá & 0,33 & 0,05 & 0,62 & $-1,88$ & $-1,65$ \\
\hline Sete Lagoas & 0,26 & 0,05 & 0,70 & $-2,14$ & $-1,90$ \\
\hline Jundiai & 0,29 & 0,08 & 0,64 & $-1,95$ & $-1,72$ \\
\hline Rib. Preto & 0,26 & 0,09 & 0,65 & $-2,21$ & $-1,99$ \\
\hline Castro & 0,22 & 0,07 & 0,71 & $-1,64$ & $-1,47$ \\
\hline Mal. Rondon & 0,31 & 0,06 & 0,63 & $-1,86$ & $-1,63$ \\
\hline Teutônia & 0,23 & 0,05 & 0,72 & $-1,71$ & $-1,51$ \\
\hline Carazinho & 0,26 & 0,08 & 0,66 & $-1,76$ & $-1,50$ \\
\hline
\end{tabular}

Fonte: Dados da pesquisa

Entre os fatores de produção, a competitividade mostrou-se mais sensivel ao capital. Os corredores Teutônia, Castro e Sete Lagoas 
apresentaram maior sensibilidade, enquanto Ibiá, Rỉo Verde e Mal. Cândido Rondon foram os menos sensiveis, em ambas as cadeias produtivas.

Em termos de mão-de-obra não qualificada, Castro e Teutônia foram os corredores menos sensíveis a variações no custo deste fator, enquanto os corredores Rio Verde e Ibiá demonstraram maior sensibilidade nas duas cadeias produtivas. Quanto à mão-de-obra qualificada, o menor impacto no indicador RCP ocorreu nos corredores de Goiás e Minas Gerais, nas duas cadeias produtivas. O maior se daria em Carazinho, para o leite Longa Vida e em Ribeirão Preto para o Leite em Pó.

Em termos de variações simuladas no preço preço internacional, as duas cadeias nos dez corredores teriam aumento de competitividade mais que proporcional, quando se eleva o preço do produto importado. Em ambas as cadeias, Ribeirão Preto mostrou-se mais sensível a variações de preços internacionais.

Quanto à produtividade, também haveria um impacto mais que proporcional e em sentido contrário, todavia inferior ao impacto relativo à variação do preço. Com efeito, aumento na produtividade leva a aumento em maior magnitude na competitividade de todos os corredores. Ribeirão Preto demonstrou maior sensibilidade em ambas as cadeias produtivas. Castro mostrou-se menos sensivel para a cadeia do Leite Longa Vida e Rio Verde para Leite em Pó.

As simulações demonstraram que a competitividade de ambas as cadeias são mais afetadas quando ocorrem variações no preço do produto, seguidas de variações na produtividade. A mão-de-obra não qualificada e a produtividade afetam mais a competitividade da cadeia do Leite em Pó, enquanto que a mão-de-obra qualificada e o preço impactam proporcionalmente mais a cadeia de Longa Vida. Variações no custo do Capital afetam ligeiramente mais a cadeia de Longa Vida. 
Entre os fatores de produção, a competitividade mostrou-se mais sensivel ao capital. Os corredores Teutônia, Castro e Sete Lagoas apresentaram maior sensibilidade, enquanto Ibiá, Rio Verde e Mal. Cândido Rondon foram os menos sensíveis, em ambas as cadeias produtivas.

Em termos de mão-de-obra não qualificada, Castro e Teutônia foram os corredores menos sensíveis a variações no custo deste fator, enquanto os corredores Rio Verde e Ibiá demonstraram maior sensibilidade nas duas cadeias produtivas. Quanto à mão-de-obra qualificada, o menor impacto no indicador RCP ocorreu nos corredores de Goiás e Minas Gerais, nas duas cadeias produtivas. O maior se daria em Carazinho, para o leite Longa Vida e em Ribeirão Preto para o Leite em Pó.

A Tabela 34 apresenta os indicadores de eficiência e competitividade para todos os corredores, nas duas cadeias produtivas analisadas. Por terem apresentado valores para o indicador Razão do Custo Privado menores que a unidade, todos os corredores mostraram-se competitivos. O RCP sendo inferior à unidade indica que os fatores de produção domésticos receberam mais do que seu retorno normal. As cadeias produtivas mostraram-se capazes de manter os fatores domésticos empregados, podendo inclusive vir a se expandir. Castro e Jundiaí foram, respectivamente, os corredores mais e menos competitivos, tanto para Leite Longa Vida, quanto para Leite em Pó.

O indicador Razão de Custos Domésticos indica quanto se utiliza de recursos domésticos para se economizar um dólar de divisa na importação. No caso de ser inferior à unidade, o valor dos recursos domésticos empregados na produção é inferior ao valor adicionado, indicando que a expansão desta atividade traz ganhos líquidos para o país. Informa, portanto, que o valor adicionado é mais do que suficiente para remunerar os fatores de produção pelo seu custo de oportunidade, dando origem a lucro positivo. Todos os corredores apresentaram eficiência nas duas cadeias analisadas. Novamente, 
Castro e Jundiaí, respectivamente foram os corredores com maior e menor eficiência.

Excetuando os corredores de São Paulo, em que a cadeia de Longa Vida mostrou-se mais competitiva que a do Leite em Pó, nos demais não foram registradas grandes diferenças para o indicador RCP. Quanto ao RCD, a cadeia de Leite em Pó foi signficativamente mais eficiente em todos os corredores, quando comparado com o leite Longa Vida. Em Mal. Cândido Rondon, por exemplo, o RCD do Leite em Pó foi a metade do encontrado para o Longa Vida.

Tabela 34. Indicadores de competitividade e de eficiência para as cadeias produtivas de Leite Longa Vida e Leite em Pó, por corredor.

\begin{tabular}{lcccc}
\hline Corredores & \multicolumn{2}{c}{$\begin{array}{c}\text { Competitividade (RCP) } \\
\text { Longa Vida }\end{array}$} & Leite em Pó & \multicolumn{2}{c}{ Eficiência (RCD) } \\
& 0,35 & 0,35 & 0,30 & Leite em Pó \\
\hline Piracanjuba & 0,30 & 0,31 & 0,26 & 0,17 \\
Rio Verde & 0,30 & 0,31 & 0,27 & 0,15 \\
Ibiá & 0,31 & 0,33 & 0,28 & 0,14 \\
Sete Lagoas & 0,37 & 0,43 & 0,36 & 0,15 \\
Jundiaí & 0,36 & 0,40 & 0,32 & 0,19 \\
Ribeirão Preto & 0,21 & 0,21 & 0,19 & 0,10 \\
Castro & 0,27 & 0,26 & 0,24 & 0,12 \\
Mal. Rondon & 0,24 & 0,23 & 0,21 & 0,11 \\
Teutônia & 0,24 & 0,24 & 0,19 & 0,12 \\
Carazinho & & & & \\
\hline
\end{tabular}

Fonte: Dados da pesquisa

Promoveu-se uma simulação relativa ao limite de preços que anularia a competitividade e a eficiência nas duas cadeias produtivas, para todos os corredores. Os resultados encontram-se na Tabela 35. A competitividade das cadeias deixaria de existir a partir do preço de comercialização do produto em que o indicador RCP fosse igual a unidade, medido em termos privados. Com RCP igual à unidade, é indiferente utilizar os 
fatores de produção nas cadeias em análise ou utilizá-los em outras atividades. Nesse ponto, os fatores estão recebendo valores equivalentes aos seus preços-sombra. Para a cadeia produtiva do leite Longa Vida, os preços limite variaram entre $R \$ 0,51$ (Castro) e $R \$ 0,61$ (Rib. Preto) por litro posto em São Paulo, no atacado. Os corredores que se mostraram mais resistentes à perda de competitividade foram Castro e os do Rio Grande do Sul, enquanto que os menos competitivos foram os de São Paulo.

Para Leite em Pó, os preços limite ficaram numa faixa de $R \$ 3,09$ a $\mathrm{R} \$ 4,17$, por kg de leite em pó colocado no mercado de São Paulo, a preços de atacado, variando por corredor. Novamente Castro e os corredores do Rio Grande do Sul foram mais competitivos, contra os de São Paulo.

Tabela 35. Preços de comercialização em São Paulo, os quais a competitividade e a eficiência são anuladas, cadeias produtivas de Leite Longa Vida e Leite em Pó, por corredor.

\begin{tabular}{lcccccccc}
\hline & \multicolumn{3}{c}{ Competitividade (RCP) } & \multicolumn{3}{c}{ Eficiência (RCD) } \\
& $\mathrm{R} \$$ & LS $\$$ & $\mathrm{R} \$$ & US $\$$ & $\mathrm{R} \$$ & US $\$$ & $\mathrm{R} \$$ & US $\$$ \\
\hline Piracanjuba & 0,68 & 0,32 & 4,58 & 2,16 & 0,669 & 0,32 & 4,54 & 2,15 \\
Rio Verde & 0,67 & 0,32 & 4,25 & 2,01 & 0,666 & 0,31 & 4,23 & 2,00 \\
Ibiá & 0,69 & 0,33 & 4,70 & 2,22 & 0,679 & 0,32 & 4,63 & 2,19 \\
S. Lagoas & 0,72 & 0,34 & 5,01 & 2,37 & 0,719 & 0,34 & 5,01 & 2,37 \\
Jundiaí & 0,63 & 0,30 & 4,46 & 2,11 & 0,625 & 0,30 & 4,43 & 2,09 \\
Rib. Preto & 0,65 & 0,31 & 4,63 & 2,19 & 0,637 & 0,30 & 4,53 & 2,14 \\
Castro & 0,63 & 0,30 & 4,01 & 1,89 & 0,627 & 0,30 & 3,93 & 1,86 \\
Mal. Rond. & 0,68 & 0,32 & 4,51 & 2,13 & 0,677 & 0,32 & 4,46 & 2,11 \\
Teutônia & 0,65 & 0,31 & 3,57 & 1,69 & 0,645 & 0,30 & 3,55 & 1,68 \\
Carazinho & 0,66 & 0,31 & 3,68 & 1,74 & 0,667 & 0,32 & 3,67 & 1,73 \\
\hline
\end{tabular}

Fonte: Dados da pesquisa

Nota: Inclui impostos 
Quanto aos preços limite em termos de eficiência verificou-se que, para o leite Longa Vida, os preços no atacado estiveram entre $\mathrm{R} \$ 0,51$ (Castro) e $R \$ 0,60$ (Rib. Preto e Sete Lagoas) por litro de leite colocado em São Paulo. Aos preços da Tabela 34, por corredor, é indiferente ao país produzir ou importar. Para valores inferiores aos apresentados o recomendável seria a importação, pois o valor adicionado na cadeia a preços internacionais seria insuficiente para remunerar os fatores de produção domésticos pelo seu custo de oportunidade. Não seria, portanto, uma estratégia socialmente eficiente economizar divisas com o estímulo à produção interna em substituição à importação. Para a cadeia de Leite em Pó o limite de preços no atacado e por kg colocado em São Paulo variaria entre $R \$ 3,01$ e $R \$ 4,14$, de acordo com cada corredor. Novamente, Castro e os corredores do Rio Grande do Sul resistem mais a uma queda de preços, enquanto que os de São Paulo são menos resistentes.

\subsection{Comentários finais}

Os resultados obtidos demonstraram que as propriedades são eficientes, embora nem todas sejam competitivas. São Paulo tem, em média, propriedades menos eficientes entre os cinco estados, enquanto que as mais eficientes encontram-se em Castro e Teutônia. Todas as propriedades são desprotegidas e em todas ocorreram transferência de recursos para a economia .

Quanto às cadeias produtivas, embora todos os corredores tenham se mostrado eficientes e competitivos, os corredores de São Paulo novamente apresentaram desempenho menos favorável. O nível de desproteção foi reduzido para Longa Vida e mais acentuado para Leite em Pó. 
O custo representado pela utilização de embalagens cartonadas no Longa Vida merece destaque. A opção brasileira pelo consumo de leite fluido onera o produto. $\mathrm{O}$ custo da embalagem equivale a todos os custos variáveis dessa cadeia produtiva. Para o laticínio, o custo é um pouco menor que o de aquisição, captação e transporte do leite até a unidade de processamento.

Quanto às simulações, é evidente o grande impacto que variações no preço dos produtos lácteos importados têm em suas respectivas cadeias. Decisões de políticas comercial e macroeconômicas têm, portanto, repercussões acentuadas no SAG do Leite em geral, especialmente no ambiente das fazendas e das cadeias. Dado o quadro generalizado de penalizações encontrado, decisões de política externa comercial, de tarifações federais e principalmente estaduais, bem como ações públicas e de coordenação privada, que reduzam o poder de mercado de empresas compradoras, poderiam resultar em compensações, levando os produtores a conviver com preços de insumos e preços artificiais de leite, vigentes no mercado internacional. 


\section{CONCLUSÕES}

A primeira conclusão geral é que a atividade láctea mostrou-se intensamente regulamentada em todo o mundo, colocando-a distante de postulados do livre comércio. Isso leva a distorções sólidas nos mercados domésticos, com reflexos apreciáveis no mercado internacional, que é estreito, por consequência. A União Européia tem, no seu desenho de intervenção, uma explícita concepção social e, dessa forma, atende aos interesses dos grupos de pressão existentes. A sociedade, por meio de preços de derivados lácteos elevados e de comprometimentos orçamentários específicos, paga essa conta sem que sejam perceptíveis pressões contrárias suficientemente fortes, a ponto de superar aquelas advindas dos grupos que se beneficiam com a politica. Nos Estados Unidos e Canadá, situação similar se verifica. No Japão, chaga-se ao extremo de se inserir leite e seus derivados no rol de produtos transacionados pelo Estado.

As vultosas distorções de mercado, derivadas de políticas de intervenção, geram situações em que países como a Suíça colocam-se entre importantes exportadores de derivados lácteos, enquanto paises que remuneram a matéria-prima aos menores preços do mercado, caso do Brasil, apresentam-se como históricos importadores.

A implementação dos pressupostos do Acordo Agrícola não assegurou a abertura de importantes mercados, como o da União Européia, Canadá, Estados Unidos e Japão. No longo processo de negociação, esses países conservaram a base de suas políticas e, consequentemente, a proteção 
aos seus mercados. No caso dos EUA, o critério seletivo de redução de políticas de proteção adotado levou à permanência de proteção em produtos lácteos pouco competitivos e reduziu a proteção em produtos competitivos, como a manteiga. Na UE, o período-base de referência para cálculo de redução da proteção levou a uma situação em que aquele bloco aplica um conjunto de políticas protecionistas aquém do que está autorizado pelo Acordo Agrícola. Por outro lado, a UE aumentou a competitividade de seus produtos lácteos, ao ter promovido redução de restrição à importação de cereais - base da alimentação das cadeias produtivas de proteínas animais.

Quanto aos países em desenvolvimento, visando salvaguardá-los, o Acordo Agrícola previu menor redução de proteção. Decisão inócua, contudo, pois, em geral, já tinham aberto os mercados além do exigido, motivados por políticas de desregulamentação ancoradas em acordos firmados com organismos internacionais, como o Fundo Monetário Internacional e o Banco Mundial.

A construção de blocos econômicos, como a discussão da ALCA, não assegura o livre comércio de produtos lácteos entre os países participantes. Essa é a experiência que deriva do NAFTA, pois os EUA extrapolou o ambiente interno ao bloco, de negociação, levando a OMC a posicionar-se contra a política de proteção adotada no Canadá - um caso concreto que deve ser considerado por agentes que entendem que o simples fato de formação de uma União Aduaneira ou Área de Livre Comércio, garante a entrada facilitada de produtos lácteos nos países que se associem ao Brasil.

No caso específico do Brasil, os 57 anos de história de intervenção governamental no mercado de leite e derivados demonstram que os objetivos perseguidos foram diferentes daqueles dos países desenvolvidos em pauta. A "política de alimentos baratos" tem visado a transferência de renda dos agentes inseridos na cadeia láctea para a sociedade. Num primeiro momento, de forte 
intervenção e mercado autárquico, essa política não assegurou ganhos aos produtores. Ao contrário, desestimulou a produção comercial. A partir de 1991, com a desregulamentação, a ótica continuou sendo o abastecimento, com prioridade ao controle da inflação, pois leite e derivados têm elevado peso na composição de índices de custo de vida. Nesse novo cenário, contudo, o tabelamento foi substituído pela facilidade de importação de produtos a preços reduzidos, consequência das distorções existentes no mercado internacional de lácteos.

Os dados de produção e consumo demonstraram que os lácteos caracterizam-se no Brasil como um produto tipicamente "bem-salário". Nos momentos em que ocorreu aquecimento da economia e/ou redução do imposto inflacionário, principalmente nas décadas de oitenta e noventa, imediatamente ocorreu pressão de consumo, impossivel de ser plenamente atendida pela produção doméstica, o que levou a picos de importação. O inverso também mostrou-se verdadeiro.

A análise do comportamento de preços recebidos pelos produtores nos cinco principais estados brasileiros demonstrou que o preço apresentou tendência de redução desde meados dos anos oitenta. Não é correto, portanto, afirmar que foi a desregulamentação responsável por essa tendência. Esse fato ainda auxilia no entendimento do porquê não ocorreram drásticas quedas de produção e de preços recebidos por produtores logo após a liberação da importação, fato registrado com o trigo e algodão, por exemplo. Os dados também demonstram que é cada vez menor a variação de preços recebidos pelos produtores entre os cinco estados, em contradição com a crença reinante entre os produtores. Quanto mais distante dos atuais dias, maiores foram as variações de preço.

De fato, os critérios adotados na definição dos corredores pesquisados também desautorizam afirmações de que o leite é atividade não 
competitiva, tendo papel acessório, de complemento da receita da fazenda. Dinamismo foi a "pedra de toque" na definição de corredores pesquisados. Nos corredores do Rio Grande do Sul, Rio Verde e Mal. Cândido Rondon, o preço da terra teve como indexador a soja, em Ibiá o café e em Ribeirão Preto a canade-açúcar. Nesses casos, portanto, houve concorrência com produtos de exportação e, ainda assim, o leite mostrou-se competitivo.

Nos demais corredores, a concorrência dos fatores foi com grandes centros. Sete Lagoas dista $76 \mathrm{~km}$ de Belo Horizonte e $43 \mathrm{~km}$ de Betim, importante complexo industrial. A coleta de dados se deu até em propriedades próximas da montadora Fiat. $O$ corredor Jundiaí teve coleta de dados em propriedades localizadas nos municípios próximos a Bragança Paulista, que fica a $89 \mathrm{~km}$ de São Paulo-Capital e a $65 \mathrm{~km}$ de Campinas. Piracanjuba está a 80 $\mathrm{km}$ de Goiânia, enquanto os fatores capital e trabalho do corredor Castro, no Paraná, sofreram duplo impacto: estão a $150 \mathrm{~km}$ de Curitiba e tinham terras dedicadas à produção de exportáveis, como soja. Por outro lado, o contato in loco com os produtores que formaram os corredores do Rio Grande do Sul, Goiás e Mal. Cândido Rondon demonstrou que a maioria optou pela produção de leite na década passada, em decorrência de frustração com outras atividades agrícolas consideradas mais rentáveis.

O levantamento de dados também permite afirmar que não é correta a afirmação de que, dada a transformação estrutural em curso no SAG do leite, pouco espaço de sobrevivência haveria para a produção familiar. Ao que parece, confunde-se produção familiar, conceituada como aquela obtida principalmente com mão-de-obra da família, com produção de subsistência ou pequena produção. Embora a amostragem seja não representativa, o levantamento em 150 propriedades mostrou a vitalidade da produção familiar na atividade primária de leite. Os corredores do sul, onde a produção está estruturada na família, são aqueles que melhor desempenho apresentaram, ao contrário de corredores como os de São Paulo, em que prepondera a mão-de- 
obra contratada. Em condições iguais quanto a frete, preço recebido e incidência de impostos praticados no sul, poucas seriam as propriedades em condições competitivas nesse estado do sudeste.

Este tópico parece requisitar maior atenção de economistas e sociólogos, principalmente quando se verifica, conforme as visitas evidenciaram, a importância da mulher nos sistemas de produção dos estados do sul, no cuidado diário da produção e nas decisões do negócio, ao contrário do que se verificou nos corredores do sudeste/centro-oeste, em que sua participação é coadjuvante - quando muito, ou majoritariamente inexistente.

Durante a década de noventa, após a desregulamentação, a indústria de laticínios adotou o conceito de logística integrada, visando a redução de custos e a melhoria da qualidade e diversificação dos produtos lácteos, motivada pelo aumento da competição. Investimentos foram feitos no sentido de levar produtores a adotarem tecnologias. Trabalho paralelo foi feito por federações estaduais de agricultura e por entidades de interesse dos produtores de leite, que também desenvolveram ações consistentes no sentido de organização de representados.

É nesse contexto que foi encontrado uma segunda conclusão de ordem geral. Considerando-se o fato da amostragem utilizada na pesquisa não ter sido representativa, pois visou produtores mais dinâmicos, posições explicitadas pelos entrevistados demonstraram que ainda muito há o que fazer em termos de estruturação da cadeia produtiva. O produtor típico da amostra conhece pouco o trabalho das instituições que o representa, não se informa sobre decisões de governo e não é sindicalizado. Atribui à indústria de laticínios a responsabilidade pelos principais problemas que $o$ aflige e entende que os poderes executivo e, principalmente, o legislativo, não cumprem o papel de defesa de seus interesses. Sob esse aspecto, o produtor de leite amostrado demonstrou que votou mal nas eleições de 1998. Apesar disso, em quatro dos 
cinco estados pesquisados ocorreram instalações de Comissões Parlamentares de Inquérito, nas quais o produtor de leite mereceu atenção quanto aos seus problemas.

Os produtores também mostraram-se pouco informados sobre critérios de bonificação adotados pelas empresas, base para a política de estímulo ao aumento de produção e produtividade. Numa comparação entre produtores, percebeu-se que aqueles vinculados a cooperativas são melhor informados e mais participativos que os vinculados a empresas privadas típicas.

Em suma, os produtores evoluíram no que se refere aos custos de produção, pois estão cônscios da necessidade de reduzi-los para manter a competitividade. Estão, contudo, pouco sensiveis a fatores que afetam os custos de transação.

O terceiro conjunto conclusivo diz respeito aos resultados obtidos quanto à aferição de competitividade e eficiência. As propriedades pesquisadas mostraram-se competitivas em sua grande maioria (87\%). Aquelas que apresentaram desempenho econômico negativo, em geral obtiveram produção de leite restrita, o que sinaliza ser o volume de leite produzido uma variável relevante na atividade, dado o impacto nos custos fixos, no frete e na receita. As fazendas do sul do país superaram o elevado custo dos fatores de produção com elevada produtividade, enquanto que as de Minas Gerais obtiveram preços de comercialização do leite mais favoráveis, contribuindo decisivamente para o desempenho obtido. Nos corredores de Goiás e São Paulo foram registrados 19 dos 26 casos de propriedades não competitivas, contra 5 no Rio Grande do Sul e Paraná. Nos corredores de Minas Gerais e Teutônia todas propriedades foram competitivas. Por outro lado, todas as propriedades foram eficientes, em todos os corredores. Aquelas que formaram os corredores dos estados do sul foram as mais eficientes, seguidas de um segundo bloco formado pelos 
corredores de Minas Gerais e Goiás. As propriedades de São Paulo foram menos eficientes.

A análise das cadeias produtivas mostrou que todos os corredores de produção de leite Longa Vida foram competitivos e eficientes. Os corredores do sul e Rio Verde foram mais competitivos, contra os menos competitivos de São Paulo, Minas Gerais e Piracanjuba. Essas posições foram mantidas na análise de eficiência.

Merece registro, contudo, o custo elevado da embalagem cartonada, que é o item que mais onera a cadeia, e correspondeu a mais de $50 \%$ de todos os custos variáveis consolidados na cadeia, em todos os corredores. Para a indústria, o custo da embalagem está próximo do custo de obtenção do leite não beneficiado, posto na plataforma de processamento. Pela importância que representa o leite Longa Vida no consumo fluido, tendo contribuído para viabilizar o aumento de produção em estados exportadores líquidos, e dado o fato da embalagem ter mercado altamente oligopolizado, tendendo para o monopólio, é requerida atenção especial de órgãos responsáveis pela defesa da concorrência, como o CADE.

Também todos os corredores de produção de Leite em Pó mostraram-se competitivos e eficientes. As posições relatadas para leite Longa Vida se repetiram para Leite em Pó. Merece registro o fato de os corredores de São Paulo terem se colocado como menos eficientes em termos de produção de leite nas propriedades e na produção de leite Longa Vida e Leite em Pó. Os corredores de Minas Gerais, que obtiveram boas posições quanto à eficiência das propriedades, não reproduziram o mesmo desempenho nas cadeias produtivas. Em Goiás foram encontrados comportamentos distintos: Rio Verde com bom desempenho, enquanto Piracanjuba com desempenho inferior, embora favorável. Os corredores do sul foram os que mais se destacaram positivamente, em todos os aspectos de análise. 
De modo geral, os indicadores permitem concluir que as fazendas são mais desprotegidas que as cadeias. Entre essas, Leite em Pó é bastante desprotegida, enquanto Leite Longa Vida sofre reduzida desproteção.

Além das condições de produção e produtividade das propriedades de cada corredor, dois fatores foram relevantes para viabilizar a competitividade das cadeias produtivas analisadas. O primeiro referiu-se ao custo de frete. $A$ literatura citada ao longo da pesquisa demonstrou que, antes da adoção do processo de captação do leite a granel, esse item correspondeu a até $25 \%$ do preço recebido pelo produtor. A redução de custos com frete na captação viabilizou a redução de custos do produto final. Essa constatação é relevante, pois é recorrente a comparação de produtores em relação aos preços que recebiam e os que hoje recebem. Nos preços comparados está inserido o custo de frete. Logo, é de se esperar que, com custos de frete mais elevados no passado, os preços recebidos também tivessem que ser mais elevados.

Um segundo aspecto diz respeito ao ICMS. A isenção desse imposto sobre os lácteos no Rio Grande do Sul e São Paulo mostrou-se de vital importância para as cadeias produtivas analisadas. No primeiro estado, viabilizou a colocação da produção à longa distância, enquanto, no segundo, permitiu que a produção suportasse a concorrência com corredores que apresentaram melhor desempenho.

Os resultados obtidos nesta pesquisa confirmaram a hipótese inicial. Políticas públicas e falhas de mercado, tanto internacionais quanto domésticas, penalizam a produção de leite nas propriedades e nas cadeias produtivas de dois dos principais produtos lácteos transacionados. O Brasil remunera a produção de leite na propriedade aos preços mais reduzidos do mundo, entre US\$ 0,10 e US\$ 0,20 por litro, e ainda assim sofre impacto de importações competitivas artificialmente. 
Após a desregulamentação do leite no Brasil, a busca de ganhos de eficiência foi tão intensa em todos os elos que compõem a cadeia de lácteos, que se assumiu que o mercado poderia se estabilizar sem a interferência do governo. A experiência relatada em diferentes países e uma avaliação de onze anos de desregulamentação no Brasil, demonstram a necessidade de se tratar leite como assunto de Estado. Sem a intervenção econômica, a atividade láctea continuará a apresentar oscilações de crescimento e retração de demanda, instabilidade que não estimula ganhos tecnológicos de caráter permanente.

Em 2002, o Brasil iniciou decisivo esforço voltado para exportações lácteas. As condições externas parecem favoráveis no longo prazo. Organismos insuspeitos como a FAO antevêem o crescimento da demanda externa. Somese a isso, a necessidade da União Européia reduzir os subsídios aos lácteos, motivada pelo ônus orçamentário que representa num ambiente de relativa escassez, que se intensificará com a entrada de mais dez países no Bloco. Além disso, em termos de geo-política, é de supor que aquele bloco mostre-se cada vez menos refratário às reinvidicações contra os subsídios, como instrumento de troca nas negociações com os países agrícolas como o Brasil. Essa parece ser uma importante forma européia de neutralizar ações norteamericanas, que buscam hegemonia politica e econômica.

A "política de alimentos baratos" adotada pelo governo em relação ao leite, com ou sem intervenção econômica, resultou em danos à sociedade brasileira. Essa atividade demanda políticas, portanto, específicas. Isso se deve aos seguintes fatores: está disseminada em todo o território nacional, demanda investimentos reduzidos e menos complexos em termos tecnológicos que outros setores da economia e emprega mão-de-obra de difícil reinserção em outras atividades.

Dentre as ações especificas requeridas, algumas são prioritárias. A primeira diz respeito a negociações de comércio multi e bilaterais em que o 
Brasil participa. Nestes fóruns, o leite necessita ter espaço de reconhecimento pelos negociadores formais brasileiros. A redução de subsídios internacionais assegura não somente emprego e renda via produção de lácteos. Pode reverter o passivo cambial que a atividade historicamente tem representado. Dado o peso político e econômico do Brasil, não parece proveitoso deixar à Nova Zelândia o papel único de pressão para a redução dos artificialismos do mercado internacional.

A segunda ação está relacionada com a política fiscal. Leite e derivados não devem continuar a ser sobretaxados mais que proporcionalmente, em relação a outros setores da economia. A reforma tributária, sempre discutida e ainda não implementada, precisa desonerar a atividade via ação de governos estaduais. Ademais na esfera federal, torna-se necessário a implementação de estímulos à produção, visando também o mercado externo. Preço mínimo, treinamento de produtores e financiamentos assegurados são instrumentos relevantes a merecer a atenção de formuladores de politicas públicas. 
ANEXO A 
Tabela 36. Custo de produção, receita e resultado econômico por 1.000 litros de leite, por propriedade, corredor Piracanjuba, Agosto/2000 a Julho/2001. (R\$ $1,00)$

\begin{tabular}{|c|c|c|c|c|c|c|c|c|c|}
\hline \multirow{3}{*}{$\begin{array}{l}\text { Proprie- } \\
\text { Dades }\end{array}$} & \multicolumn{9}{|c|}{ Itens de Desempenho } \\
\hline & Custo & & & sto Variá & & & Custo & Receita & Resul- \\
\hline & Fixo & Total & Aliment. & M-obra & Transp. & Outros* & Total & & Tado \\
\hline 001 & 60 & 232 & 134 & 35 & 25 & 38 & 292 & 330 & 38 \\
\hline 002 & 48 & 324 & 214 & 31 & 21 & 57 & 373 & 335 & -38 \\
\hline 003 & 28 & 202 & 130 & 38 & 11 & 23 & 229 & 328 & 99 \\
\hline 004 & 43 & 182 & 104 & 42 & 09 & 27 & 226 & 352 & 126 \\
\hline 005 & 52 & 320 & 224 & 30 & 19 & 47 & 372 & 320 & -52 \\
\hline 006 & 36 & 206 & 123 & 25 & 22 & 37 & 243 & 308 & 65 \\
\hline 007 & 60 & 266 & 157 & 33 & 23 & 53 & 327 & 305 & -22 \\
\hline 008 & 63 & 270 & 170 & 21 & 23 & 55 & 333 & 321 & -12 \\
\hline 009 & 72 & 283 & 200 & 32 & 17 & 35 & 355 & 328 & -28 \\
\hline 010 & 47 & 169 & 094 & 23 & 22 & 30 & 216 & 327 & 111 \\
\hline 011 & 49 & 229 & 112 & 45 & 20 & 52 & 278 & 339 & 61 \\
\hline 012 & 54 & 227 & 148 & 23 & 19 & 37 & 281 & 345 & 64 \\
\hline 013 & 33 & 239 & 125 & 36 & 20 & 58 & 272 & 303 & 30 \\
\hline 014 & 42 & 191 & 123 & 21 & 13 & 35 & 233 & 340 & 107 \\
\hline 015 & 71 & 250 & 138 & 36 & 16 & 61 & 320 & 300 & -20 \\
\hline
\end{tabular}

Fonte: Dados da pesquisa

* Custos de reprodução, sanidade, contribuições a sindicatos, associações, pagamentos de INSS e IPVA.

Tabela 37. Indicadores selecionados de desempenho em propriedades com prejuizo, corredor Piracanjuba, Agosto/2000 a Julho/2001.

\begin{tabular}{lcccccccc}
\hline \multicolumn{1}{c}{ Indicadores } & Corredor & \multicolumn{7}{c}{ Propriedades } \\
& & 002 & 005 & 007 & 008 & 009 & 015 \\
\hline Produção (I./dia) & 492 & 231 & 413 & 234 & 268 & 189 & 486 \\
Vacas em Lactação (cab.) & 50,7 & 23 & $\star$ & 30 & 38 & 29 & $\star$ \\
Vacas Lactação/Nacas (\%) & 73,6 & $\star$ & 62,5 & 65,2 & $\star$ & $\star$ & 69,5 \\
Vacas/Hectare (U.A.) & 2,94 & $\star$ & 0,66 & 0,84 & 2,10 & $\star$ & 1,33 \\
Produção/Hectare(I./ha) & 7.004 & $\star$ & 1.101 & 1.403 & 3.769 & $\star$ & 1.832 \\
Produção/Vaca (I./I.A.) & 3.542 & $\star$ & 2.742 & 2.853 & 2.571 & 2.373 & 2.428 \\
Produção/Concentrado (I./kg) & 4,3 & 2,7 & 2,8 & $\star$ & 2,1 & $\star$ & $\star$ \\
Produção/Mão-de-obra (I./d-h.) & 418 & $\star$ & $\star$ & 276 & $\star$ & 135 & 405 \\
Custo Hora-trator (R\$) & 14,30 & $*$ & 16,70 & 20,00 & $*$ & $\star$ & 20,80 \\
\hline
\end{tabular}

Fonte: Dados da Pesquisa

* Não se aplica 
Tabela 38. Custo de produção, receita e resultado econômico por 1.000 litros de leite, por propriedade, corredor Rio Verde, Agosto/2000 a Julho/2001. (R\$1,00)

\begin{tabular}{cccccccccc}
\hline $\begin{array}{c}\text { Proprie- } \\
\text { dades }\end{array}$ & $\begin{array}{c}\text { Custo } \\
\text { Fixo }\end{array}$ & Total & \multicolumn{9}{c}{$\begin{array}{c}\text { Custens de Desempenho } \\
\text { Aliment. }\end{array}$} & M-obra & Transp. & Outros & Custo & Total & Receita & $\begin{array}{c}\text { Resul- } \\
\text { Tado }\end{array}$ \\
\hline 016 & 46 & 277 & 196 & 34 & 11 & 36 & 323 & 380 & 57 \\
017 & 77 & 200 & 144 & 20 & 10 & 27 & 278 & 360 & 82 \\
018 & 53 & 180 & 120 & 26 & 13 & 21 & 233 & 300 & 67 \\
019 & 48 & 233 & 163 & 18 & 18 & 34 & 282 & 310 & 28 \\
020 & 42 & 190 & 120 & 39 & 18 & 13 & 232 & 345 & 113 \\
021 & 53 & 266 & 183 & 37 & 0 & 46 & 318 & 382 & 63 \\
022 & 91 & 275 & 194 & 18 & 18 & 45 & 366 & 401 & 35 \\
023 & 135 & 228 & 104 & 33 & 24 & 68 & 364 & 303 & -61 \\
024 & 64 & 192 & 116 & 23 & 23 & 30 & 256 & 296 & 40 \\
025 & 22 & 173 & 98 & 30 & 21 & 24 & 196 & 294 & 98 \\
026 & 38 & 240 & 175 & 22 & 12 & 32 & 278 & 405 & 127 \\
027 & 56 & 243 & 134 & 53 & 22 & 34 & 300 & 300 & 0 \\
028 & 68 & 202 & 104 & 49 & 20 & 30 & 270 & 309 & 39 \\
029 & 58 & 348 & 233 & 46 & 19 & 49 & 405 & 395 & -10 \\
030 & 63 & 279 & 183 & 46 & 13 & 37 & 342 & 332 & -10 \\
\hline
\end{tabular}

Fonte: Dados da pesquisa

* Custos de reprodução, sanidade, contribuições a sindicatos, associações, pagamentos de INSS e IPVA.

Tabela 39. Indicadores selecionados de desempenho em propriedade com prejuizo, corredor Rio Verde, Agosto/2000 a Julho/2001.

\begin{tabular}{lcccc}
\hline Indicadores & Corredor & \multicolumn{3}{c}{ Propriedade } \\
& & 023 & 029 & 030 \\
\hline Produção (I./dia) & 612 & 198 & 426 & 458 \\
Vacas em Lactação (cab.) & 67 & 52 & 50 & 41 \\
Vacas Lactação/Nacas (\%) & 72,34 & 48,60 & 61,73 & 65,08 \\
Vacas/Hectare (U.A.) & 2,08 & n.a. & $*$ & 0,48 \\
Produção/Hectare (I./ha) & 4.904 & 2.262 & $*$ & 1.266 \\
Produção/Naca (I./U.A.) & 3.561 & 1.392 & 3.112 & $*$ \\
Produção/Concentrado (1./kg) & 5,25 & $*$ & 3,48 & 3,67 \\
Produção/Mão-de-obra (1./d-h.) & 428 & 198 & 153 & 306 \\
Custo Hora-trator (R\$) & 15,33 & $*$ & $*$ & 16,04 \\
\hline
\end{tabular}

Fonte: Dados da Pesquisa

* Não se aplica 
Tabela 40. Custo de produção, receita e resultado econômico por 1000 litros de leite produzido, corredor Ibiá, Agosto/2000 a Julho/2001. (R\$1,00)

\begin{tabular}{|c|c|c|c|c|c|c|c|c|c|}
\hline \multirow{3}{*}{$\begin{array}{c}\text { Proprie- } \\
\text { Dades }\end{array}$} & \multicolumn{9}{|c|}{ Itens de Desempenho } \\
\hline & \multirow{2}{*}{$\begin{array}{l}\text { Custo } \\
\text { Fixo }\end{array}$} & \multicolumn{5}{|c|}{ Custo Variável } & \multirow{2}{*}{$\begin{array}{l}\text { Custo } \\
\text { Total }\end{array}$} & \multirow[t]{2}{*}{ Receita } & \multirow{2}{*}{$\begin{array}{l}\text { Resul- } \\
\text { Tado }\end{array}$} \\
\hline & & Total & Aliment. & M-obra & Transp. & Outros* & & & \\
\hline 031 & 56 & 234 & 170 & 30 & 14 & 21 & 290 & 430 & 140 \\
\hline 032 & 62 & 218 & 141 & 23 & 14 & 40 & 280 & 421 & 141 \\
\hline 033 & 41 & 284 & 203 & 22 & 14 & 45 & 325 & 404 & 79 \\
\hline 034 & 36 & 204 & 126 & 18 & 14 & 46 & 240 & 395 & 155 \\
\hline 035 & 31 & 302 & 220 & 30 & 15 & 37 & 333 & 419 & 85 \\
\hline 036 & 40 & 230 & 175 & 13 & 14 & 28 & 270 & 369 & 99 \\
\hline 037 & 60 & 272 & 197 & 13 & 17 & 45 & 332 & 358 & 26 \\
\hline 038 & 42 & 286 & 197 & 47 & 16 & 26 & 328 & 415 & 86 \\
\hline 039 & 43 & 227 & 167 & 12 & 15 & 32 & 270 & 392 & 122 \\
\hline 040 & 43 & 283 & 223 & 15 & 17 & 27 & 325 & 370 & 45 \\
\hline 041 & 71 & 319 & 198 & 52 & 13 & 56 & 390 & 392 & 2 \\
\hline 042 & 25 & 239 & 166 & 39 & 12 & 22 & 265 & 374 & 109 \\
\hline 043 & 33 & 253 & 203 & 19 & 11 & 20 & 285 & 363 & 78 \\
\hline 044 & 42 & 187 & 96 & 34 & 12 & 45 & 229 & 349 & 120 \\
\hline 045 & 36 & 183 & 126 & 24 & 4 & 30 & 219 & 349 & 130 \\
\hline
\end{tabular}

Fonte: Dados da pesquisa

* Custos de reprodução, sanidade, contribuições a sindicatos, associações, pagamentos de INSS e IPVA.

Tabela 41. Custo de produção, receita e resultado econômico por 1.000 litros de leite produzido, corredor Sete Lagoas, Agosto/2000 a Julho/2001. (R\$1,00)

\begin{tabular}{|c|c|c|c|c|c|c|c|c|c|}
\hline \multirow{3}{*}{$\begin{array}{l}\text { Proprie- } \\
\text { Dades }\end{array}$} & \multicolumn{9}{|c|}{ Itens de Desempenho } \\
\hline & \multirow{2}{*}{$\begin{array}{l}\text { Custo } \\
\text { Fixo }\end{array}$} & \multicolumn{5}{|c|}{ Custo Variável } & \multirow{2}{*}{$\begin{array}{l}\text { Custo } \\
\text { Total }\end{array}$} & \multirow[t]{2}{*}{ Receita } & \multirow{2}{*}{$\begin{array}{l}\text { Resul- } \\
\text { Tado }\end{array}$} \\
\hline & & Total & Aliment. & M-obra & Transp. & Outros $^{*}$ & & & \\
\hline 046 & 31 & 275 & 209 & 25 & 9 & 32 & 306 & 360 & 54 \\
\hline 047 & 50 & 273 & 190 & 32 & 13 & 38 & 323 & 383 & 60 \\
\hline 048 & 50 & 300 & 220 & 13 & 14 & 52 & 350 & 397 & 47 \\
\hline 049 & 79 & 285 & 215 & 21 & 14 & 34 & 363 & 401 & 38 \\
\hline 050 & 39 & 193 & 129 & 23 & 13 & 29 & 232 & 390 & 157 \\
\hline 051 & 43 & 327 & 245 & 33 & 14 & 35 & 370 & 388 & 18 \\
\hline 052 & 63 & 244 & 182 & 19 & 6 & 36 & 307 & 393 & 86 \\
\hline 053 & 46 & 289 & 204 & 25 & 14 & 46 & 335 & 382 & 47 \\
\hline 054 & 57 & 303 & 243 & 7 & 14 & 39 & 360 & 402 & 42 \\
\hline 055 & 25 & 223 & 150 & 19 & 14 & 40 & 248 & 402 & 154 \\
\hline 056 & 35 & 331 & 251 & 16 & 16 & 48 & 367 & 376 & 9 \\
\hline 057 & 41 & 216 & 155 & 22 & 14 & 25 & 257 & 388 & 131 \\
\hline 058 & 49 & 286 & 212 & 33 & 5 & 36 & 335 & 349 & 14 \\
\hline 059 & 46 & 223 & 149 & 22 & 9 & 43 & 269 & 398 & 129 \\
\hline 060 & 52 & 288 & 217 & 17 & 9 & 45 & 339 & 396 & 57 \\
\hline
\end{tabular}

Fonte: Dados da pesquisa

* Custos de reprodução, sanidade, contribuições a sindicatos, associações, pagamentos de INSS e IPVA. 
Tabela 42. Custo de produção, receita e resultado econômico por 1.000 litros de leite, por propriedade, corredor Jundiaí. Agosto/2000 a Julho/2001. (R\$1,00)

\begin{tabular}{|c|c|c|c|c|c|c|c|c|c|}
\hline \multirow{3}{*}{$\begin{array}{c}\text { Proprie- } \\
\text { dades }\end{array}$} & \multicolumn{9}{|c|}{ Itens de Desempenho } \\
\hline & Custo & & & sto Varie & vel & & Custo & Receita & Resul- \\
\hline & Fixo & Total & Aliment. & M-obra & Transp. & Outros ${ }^{\star}$ & Total & & Tado \\
\hline 061 & 100 & 295 & 192 & 32 & 20 & 52 & 395 & 381 & -14 \\
\hline 062 & 48 & 370 & 245 & 50 & 31 & 44 & 418 & 392 & -26 \\
\hline 063 & 71 & 311 & 217 & 36 & 19 & 39 & 382 & 398 & 16 \\
\hline 064 & 47 & 333 & 249 & 28 & 12 & 43 & 380 & 359 & -21 \\
\hline 065 & 49 & 325 & 212 & 35 & 21 & 57 & 374 & 324 & -50 \\
\hline 066 & 51 & 324 & 183 & 45 & 22 & 75 & 375 & 375 & 0 \\
\hline 067 & 72 & 262 & 154 & 39 & 21 & 49 & 335 & 406 & 71 \\
\hline 068 & 67 & 282 & 140 & 41 & 20 & 81 & 349 & 381 & 31 \\
\hline 069 & 43 & 261 & 169 & 55 & 11 & 27 & 304 & 397 & 93 \\
\hline 070 & 24 & 185 & 129 & 12 & 16 & 28 & 209 & 336 & 127 \\
\hline 071 & 44 & 254 & 171 & 25 & 19 & 39 & 298 & 347 & 49 \\
\hline 072 & 39 & 231 & 156 & 21 & 19 & 35 & 270 & 367 & 97 \\
\hline 073 & 31 & 221 & 146 & 34 & 20 & 22 & 252 & 367 & 115 \\
\hline 074 & 75 & 357 & 200 & 53 & 32 & 73 & 431 & 396 & -35 \\
\hline 075 & 89 & 262 & 152 & 41 & 20 & 48 & 350 & 362 & 12 \\
\hline
\end{tabular}

Fonte: Dados da pesquisa

* Custos de reprodução, sanidade, contribuições a sindicatos, associações, pagamentos de INSS e IPVA.

Tabela 43. Indicadores selecionados de desempenho em propriedades com prejuízo, corredor Jundiaí, Agosto/2000 a Julho/2001.

\begin{tabular}{|c|c|c|c|c|c|c|}
\hline \multirow[t]{2}{*}{ Indicadores } & \multirow[t]{2}{*}{ Corredor } & \multicolumn{5}{|c|}{ Propriedades } \\
\hline & & 061 & 062 & 064 & 065 & 074 \\
\hline Produção & 398 & * & 209 & * & 131 & 194 \\
\hline Vacas em lactação (cab.) & 36,5 & * & 14 & * & 15 & 16 \\
\hline Vacas Lactação/Vacas (\%) & 60,7 & 51,1 & * & 58,3 & * & * \\
\hline Vacas/Hectare (UA) & 2,7 & 1,6 & 1,3 & ${ }^{*}$ & 2,5 & * \\
\hline Produção/Hectare (1.000 I./ha) & 7,24 & 2,73 & 4,86 & 4,59 & 5,04 & * \\
\hline Produção/Vaca(1.000 I./UA) & 4,29 & 4,02 & * & 2,73 & 3,18 & * \\
\hline Produção/Concentrado (l./kg) & 4,0 & 2,0 & 2,2 & 2,5 & $*$ & * \\
\hline Produção/Mão-de-Obra(l./d-h) & 307 & * & 235 & * & 177 & * \\
\hline Preço Terra $(R \$ 1.000,00)$ & 4,21 & * & 5,00 & 5,00 & 6,20 & * \\
\hline Preço Vaca $(R \$ 1.000,00)$ & 0,84 & 1,30 & 0,90 & * & * & 1,00 \\
\hline Custo Hora-trator $(R \$)$ & 11,89 & 13,81 & 16,00 & * & * & 16,00 \\
\hline
\end{tabular}

Fonte: Dados da Pesquisa

* Não se aplica 
Tabela 44. Custo de produção, receita e resultado econômico por 1.000 litros de leite, por propriedade, corredor Ribeirão Preto, Agosto/2000 a Julho/2001. (R\$ $1,00)$

\begin{tabular}{|c|c|c|c|c|c|c|c|c|c|}
\hline \multirow{3}{*}{$\begin{array}{l}\text { Proprie- } \\
\text { dades }\end{array}$} & \multicolumn{9}{|c|}{ Itens de Desempenho } \\
\hline & Custo & & $\mathrm{Cu}$ & sto Vari & vel & & Custo & Receita & Resul- \\
\hline & Fixo & Total & Aliment. & M-obra & Transp. & Outros* & Total & & Tado \\
\hline 076 & 70 & 276 & 205 & 21 & 11 & 39 & 346 & 380 & 34 \\
\hline 077 & 69 & 363 & 284 & 25 & 16 & 38 & 431 & 396 & -36 \\
\hline 078 & 38 & 249 & 171 & 17 & 25 & 37 & 288 & 350 & 62 \\
\hline 079 & 39 & 253 & 179 & 19 & 11 & 44 & 292 & 396 & 105 \\
\hline 080 & 64 & 302 & 240 & 24 & 0 & 39 & 366 & 399 & 33 \\
\hline 081 & 38 & 204 & 149 & 14 & 13 & 29 & 242 & 385 & 143 \\
\hline 082 & 45 & 341 & 260 & 22 & 14 & 44 & 386 & 392 & 6 \\
\hline 083 & 29 & 295 & 221 & 22 & 13 & 39 & 324 & 311 & -12 \\
\hline 084 & 53 & 298 & 228 & 23 & 11 & 36 & 350 & 396 & 46 \\
\hline 085 & 58 & 370 & 273 & 39 & 14 & 44 & 429 & 394 & -35 \\
\hline 086 & 60 & 328 & 215 & 36 & 15 & 62 & 389 & 394 & 5 \\
\hline 087 & 41 & 247 & 95 & 85 & 11 & 56 & 287 & 350 & 63 \\
\hline 088 & 56 & 359 & 249 & 39 & 15 & 56 & 415 & 393 & -22 \\
\hline 089 & 59 & 290 & 164 & 21 & 10 & 95 & 349 & 334 & -15 \\
\hline 090 & 37 & 270 & 182 & 51 & 10 & 27 & 307 & 384 & 77 \\
\hline
\end{tabular}

Fonte: Dados da pesquisa

* Custos de reprodução, sanidade, contribuições a sindicatos, associações, pagamentos de INSS e IPVA.

Tabela 45. Indicadores selecionados de desempenho em propriedades com prejuízo, corredor Ribeirão Preto, Agosto/2000 a Julho/2001.

\begin{tabular}{lcccccc}
\hline \multicolumn{1}{c}{ Indicadores } & Corredor & \multicolumn{5}{c}{ Propriedades } \\
& & 077 & 083 & 085 & 088 & 089 \\
\hline \multicolumn{1}{c}{ Produção (I./dia) } & 749 & $*$ & 163 & 615 & 599 & 398 \\
Vacas em lactação & 46 & $*$ & 17 & 27 & 34 & 40 \\
Vacas Lactação/Nacas (\%) & 74,98 & $*$ & $*$ & 71,05 & 64,15 & 68,97 \\
Vacas/Hectare (UA) & 2,23 & $*$ & $*$ & 1,18 & $*$ & 2,01 \\
Produção/Hectare (I./ha) & 10.334 & $*$ & 9420 & 6957 & $*$ & 5051 \\
Produção/Naca (I./UA) & 6223 & $*$ & 3509 & $*$ & 6432 & 3636 \\
Produção/Concentrado (I./kg) & 3,68 & 1,93 & $*$ & 2,30 & 2,40 & $*$ \\
Produção/Mão-de-Obra(l./d-h) & 696 & $*$ & 409 & 420 & 399 & 614 \\
Preço Terra (R\$) & 3.321 & 4.000 & $*$ & $*$ & $*$ & $*$ \\
Custo Hora-trator (R\$) & 13,81 & 14,64 & $*$ & $*$ & $*$ & $*$ \\
\hline
\end{tabular}

Fonte: Dados da Pesquisa

* Não se aplica 
Tabela 46. Custo de produção, receita e resultado econômico por 1.000 litros de leite, por propriedade, corredor Castro, Agosto/2000 a Julho/2001. (R\$1,00)

\begin{tabular}{|c|c|c|c|c|c|c|c|c|c|}
\hline \multirow{3}{*}{$\begin{array}{c}\text { Proprie- } \\
\text { Dades }\end{array}$} & \multicolumn{9}{|c|}{ Itens de Desempenho } \\
\hline & Custo & & & sto Varié & & & Custo & Receita & Resul- \\
\hline & Fixo & Total & Aliment. & M-obra & Transp. & Outros* & Total & & tado \\
\hline 091 & 75 & 321 & 200 & 32 & 6 & 83 & 396 & 366 & -30 \\
\hline 092 & 43 & 197 & 132 & 21 & 5 & 39 & 241 & 347 & 106 \\
\hline 093 & 32 & 219 & 162 & 28 & 6 & 23 & 251 & 359 & 108 \\
\hline 094 & 39 & 236 & 171 & 23 & 8 & 34 & 275 & 359 & 84 \\
\hline 095 & 48 & 233 & 166 & 16 & 9 & 42 & 281 & 372 & 91 \\
\hline 096 & 52 & 236 & 161 & 15 & 8 & 52 & 288 & 352 & 64 \\
\hline 097 & 42 & 186 & 134 & 20 & 6 & 26 & 228 & 357 & 129 \\
\hline 098 & 37 & 182 & 109 & 17 & 5 & 50 & 219 & 354 & 135 \\
\hline 099 & 42 & 217 & 137 & 39 & 5 & 36 & 259 & 377 & 118 \\
\hline 100 & 40 & 221 & 155 & 10 & 5 & 51 & 262 & 364 & 102 \\
\hline 101 & 36 & 191 & 132 & 11 & 6 & 41 & 226 & 353 & 127 \\
\hline 102 & 37 & 303 & 238 & 17 & 6 & 42 & 340 & 349 & 9 \\
\hline 103 & 35 & 179 & 130 & 11 & 4 & 35 & 215 & 353 & 138 \\
\hline 104 & 59 & 171 & 122 & 18 & 5 & 26 & 230 & 365 & 135 \\
\hline 105 & 38 & 263 & 186 & 23 & 6 & 48 & 302 & 368 & 66 \\
\hline
\end{tabular}

Fonte: Dados da pesquisa

* Custos de reprodução, sanidade, contribuições a sindicatos, associações, pagamentos de INSS e IPVA.

Tabela 47. Custo de produção, receita e resultado econômico por 1.000 litros de leite, por propriedade, corredor Mal. Cândido Rondon, Agosto/2000 a Julho/2001. (R\$1,00)

\begin{tabular}{cccccccccc}
\hline $\begin{array}{c}\text { Proprie- } \\
\text { Dades }\end{array}$ & $\begin{array}{c}\text { Custo } \\
\text { Fixo }\end{array}$ & Total & $\begin{array}{c}\text { Custo Variável } \\
\text { Aliment. }\end{array}$ & M-obra & Transp. & Outros* & $\begin{array}{c}\text { Custo } \\
\text { Total }\end{array}$ & Receita & $\begin{array}{c}\text { Resul- } \\
\text { tado }\end{array}$ \\
\hline 106 & 31 & 274 & 202 & 18 & 12 & 42 & 305 & 318 & 13 \\
107 & 56 & 271 & 193 & 30 & 14 & 35 & 327 & 319 & -8 \\
108 & 38 & 212 & 136 & 22 & 14 & 40 & 250 & 315 & 65 \\
109 & 35 & 270 & 197 & 27 & 14 & 32 & 305 & 332 & 27 \\
110 & 46 & 264 & 171 & 29 & 16 & 49 & 311 & 309 & -2 \\
111 & 41 & 220 & 151 & 17 & 21 & 31 & 262 & 311 & 49 \\
112 & 53 & 237 & 182 & 13 & 13 & 29 & 290 & 317 & 27 \\
113 & 45 & 186 & 129 & 10 & 19 & 28 & 230 & 316 & 86 \\
114 & 32 & 200 & 122 & 26 & 21 & 31 & 232 & 310 & 78 \\
115 & 46 & 212 & 140 & 27 & 13 & 32 & 258 & 313 & 55 \\
116 & 55 & 276 & 174 & 41 & 15 & 47 & 332 & 312 & -20 \\
117 & 42 & 221 & 131 & 43 & 13 & 34 & 263 & 310 & 47 \\
118 & 49 & 264 & 185 & 22 & 13 & 44 & 313 & 310 & -3 \\
119 & 49 & 267 & 210 & 17 & 13 & 27 & 316 & 322 & 6 \\
120 & 39 & 221 & 156 & 13 & 19 & 33 & 259 & 314 & 55 \\
\hline
\end{tabular}

Fonte: Dados da pesquisa

Nota: outros corresponde a custos de reprodução, sanidade, contribuições a sindicatos, associações, pagamentos de INSS e IPVA. 
Tabela 48. Indicadores selecionados de desempenho em propriedades com prejuízo, corredor Mal. Cândido Rondon, Agosto/2000 a Julho/2001.

\begin{tabular}{lccccc}
\hline \multicolumn{1}{c}{ Indicadores } & Corredor & \multicolumn{4}{c}{ Propriedades } \\
& & 107 & 110 & 116 & 118 \\
\hline \multicolumn{1}{c}{ Produção (I./dia) } & 508 & 495 & 366 & 406 & $*$ \\
Vacas em lactação & 29 & 25 & 18 & 32 & 27 \\
Vacas Lactação/Nacas (\%) & 82,91 & 78,13 & 78,26 & 74,42 & $\star$ \\
Vacas/Hectare (UA) & 5,53 & 4,95 & 5,02 & $\star$ & 4,39 \\
Produção/Hectare (1.000 I./ha) & 24,56 & 20,59 & 19,84 & 23,98 & 21,74 \\
Produção/Naca (1.000 I./UA) & 6,45 & $\star$ & $\star$ & 4,63 & $\star$ \\
Produção/Concentrado (I./kg) & 3,53 & 2,99 & 3,04 & 3,01 & 2,24 \\
Produção/Mão-de-Obra(l./d-h) & 344,62 & 247,34 & 230,95 & 270,63 & 193,45 \\
Preço Terra (R $\$ 1.000,00)$ & 6,93 & 9,5 & 4,89 & 4,55 & 6,24 \\
Preço Vaca (R $\$ 1.000,00)$ & 1,26 & 1,5 & 1,5 & $\star$ & 1,5 \\
Custo Hora-trator (R\$) & 15,59 & $\star$ & $\star$ & 19,93 & $\star$ \\
\hline
\end{tabular}

Fonte: Dados da pesquisa

* Não se aplica

Tabela 49. Custo de produção, receita e resultado econômico por 1.000 litros de leite, por propriedade, corredor Teutônia, Agosto/2000 a Julho/2001. (R\$1,00)

\begin{tabular}{|c|c|c|c|c|c|c|c|c|c|}
\hline \multirow{3}{*}{$\begin{array}{l}\text { Proprie- } \\
\text { Dades }\end{array}$} & \multicolumn{9}{|c|}{ Itens de Desempenho } \\
\hline & Custo & & & sto Variá & vel & & Custo & Receita & Resul- \\
\hline & Fixo & Total & Aliment. & M-obra & Transp. & Outros* & Total & & tado \\
\hline 121 & 29 & 209 & 132 & 21 & 32 & 24 & 238 & 331 & 93 \\
\hline 122 & 29 & 266 & 190 & 23 & 20 & 33 & 295 & 343 & 48 \\
\hline 123 & 39 & 237 & 151 & 25 & 27 & 33 & 276 & 352 & 76 \\
\hline 124 & 27 & 262 & 179 & 22 & 25 & 36 & 290 & 339 & 49 \\
\hline 125 & 37 & 251 & 144 & 39 & 20 & 48 & 288 & 290 & 2 \\
\hline 126 & 33 & 235 & 161 & 24 & 14 & 35 & 267 & 343 & 76 \\
\hline 127 & 21 & 218 & 153 & 12 & 18 & 35 & 239 & 319 & 80 \\
\hline 128 & 22 & 235 & 185 & 6 & 9 & 34 & 257 & 355 & 98 \\
\hline 129 & 31 & 158 & 104 & 13 & 16 & 25 & 188 & 308 & 119 \\
\hline 130 & 38 & 249 & 174 & 27 & 15 & 33 & 287 & 337 & 49 \\
\hline 131 & 44 & 209 & 130 & 24 & 10 & 45 & 254 & 309 & 55 \\
\hline 132 & 34 & 193 & 131 & 11 & 29 & 22 & 227 & 301 & 74 \\
\hline 133 & 44 & 197 & 135 & 14 & 20 & 28 & 241 & 326 & 85 \\
\hline 134 & 34 & 229 & 160 & 16 & 20 & 33 & 262 & 330 & 68 \\
\hline 135 & 46 & 134 & 79 & 24 & 12 & 19 & 180 & 309 & 129 \\
\hline
\end{tabular}

Fonte: Dados da pesquisa

* Custos de reprodução, sanidade, contribuições a sindicatos, associações, pagamentos de INSS e IPVA. 
Tabela 50. Custo de produção, receita e resultado econômico por 1.000 litros de leite, por propriedade, corredor Carazinho, Agosto/2000 a Julho/2001. (R\$1,00)

\begin{tabular}{|c|c|c|c|c|c|c|c|c|c|}
\hline \multirow{3}{*}{$\begin{array}{c}\text { Proprie- } \\
\text { Dades }\end{array}$} & \multicolumn{9}{|c|}{ Itens de Desempenho } \\
\hline & Custo & & & to Varis & vel & & Custo & Receita & Resul- \\
\hline & Fixo & Total & Aliment. & M-obra & Transp. & Outros* & Total & & tado \\
\hline 136 & 29 & 212 & 140 & 25 & 11 & 35 & 240 & 337 & 97 \\
\hline 137 & 33 & 209 & 131 & 15 & 19 & 44 & 241 & 303 & 61 \\
\hline 138 & 24 & 235 & 163 & 5 & 19 & 48 & 258 & 299 & 41 \\
\hline 139 & 58 & 209 & 111 & 40 & 14 & 44 & 268 & 300 & 32 \\
\hline 140 & 35 & 182 & 112 & 28 & 17 & 25 & 217 & 327 & 110 \\
\hline 141 & 62 & 308 & 201 & 48 & 21 & 38 & 371 & 340 & -31 \\
\hline 142 & 47 & 210 & 130 & 21 & 28 & 32 & 258 & 340 & 82 \\
\hline 143 & 34 & 215 & 155 & 6 & 14 & 40 & 249 & 402 & 153 \\
\hline 144 & 33 & 245 & 174 & 10 & 17 & 44 & 277 & 373 & 95 \\
\hline 145 & 45 & 260 & 178 & 12 & 20 & 51 & 305 & 323 & 17 \\
\hline 146 & 42 & 293 & 220 & 18 & 19 & 36 & 335 & 341 & 6 \\
\hline 147 & 38 & 239 & 141 & 20 & 25 & 52 & 277 & 325 & 48 \\
\hline 148 & 41 & 216 & 150 & 18 & 8 & 39 & 256 & 350 & 94 \\
\hline 149 & 57 & 251 & 144 & 37 & 28 & 42 & 308 & 310 & 2 \\
\hline 150 & 41 & 295 & 202 & 23 & 24 & 46 & 335 & 304 & -31 \\
\hline
\end{tabular}

Fonte: Dados da pesquisa

* Custos de reprodução, sanidade, contribuições a sindicatos, associações, pagamentos de INSS e IPVA. 
ANEXO B 
Codigo para os corredores:

1. Jundiaí; 2. Ribeirão Preto; 3. Tuetônia; 4. Carazinho; 5. Mal.

Cândido Rondon; 6. Castro; 7. Sete Lagoas; 8. Ibiá; 9. Rio Verde; 10. Piracanjuba

\section{CTOTALR}

Fontes de Variação G.L. Soma de Quadrado Quadrado Médio F Signif.

$\begin{array}{lcccc}\begin{array}{l}\text { REPET } \\ \star * \star \star * * * \\ \text { CORRED }\end{array} & 14 & 0.1205430 \mathrm{E}-01 & 0.8610215 \mathrm{E}-03 & 0.783 \\ \begin{array}{l}\text { 0.00005 } \\ \text { Residuo }\end{array} & 9 & 0.4258758 \mathrm{E}-01 & 0.4731953 \mathrm{E}-02 & 4.301 \\ \text { Coeficiente de Variação } & 126 & 3.735 & 0.1386331 & \end{array}$

T U K E Y

Variável $=$ CTOTALR $\quad(0.1100262 \mathrm{E}-02)$

CORRED Dados Médias Comparações 5\%

\begin{tabular}{rrrr}
1 & 15 & 0.9184 & $\mathrm{~A}$ \\
2 & 15 & 0.9173 & $\mathrm{~A}$ \\
7 & 15 & 0.8960 & $\mathrm{~A} \mathrm{~B}$ \\
9 & 15 & 0.8894 & $\mathrm{~A} \mathrm{~B}$ \\
8 & 15 & 0.8833 & $\mathrm{~A} \mathrm{~B}$ \\
10 & 15 & 0.8823 & $\mathrm{~A} \mathrm{~B}$ \\
5 & 15 & 0.8790 & $\mathrm{~B}$ \\
4 & 15 & 0.8787 & $\mathrm{~B}$ \\
6 & 15 & 0.8692 & $\mathrm{~B}$ \\
3 & 15 & 0.8676 & $\mathrm{~B}$ \\
\hdashline$(.050,126)=$ & 4.470 & Dms $=$ & 0.0383
\end{tabular}

\section{PRECOR}

Eontes de Variação G.L. Soma de Quadrado Quadrado Médio F Signif.

\begin{tabular}{|c|c|c|c|}
\hline $\begin{array}{c}\text { REPET } \\
\star \star \star \star \star \star * \star * t\end{array}$ & 1 & $0.2306641 E-02$ & $0.1647601 E-03$ \\
\hline CORRED & & $0.3349381 E-01$ & $0.3721535 E-02$ \\
\hline Residuo & 126 & $0.2231792 E-01$ & $0.1771264 \mathrm{E}-03$ \\
\hline
\end{tabular}


T U K $E$ E

\begin{tabular}{|c|c|c|c|c|}
\hline \multicolumn{2}{|c|}{ Variável = PRECOR } & \multicolumn{3}{|c|}{$0.1771264 E-03)$} \\
\hline CORRED & Dados & Médias & Com & para \\
\hline 7 & 15 & 0.9418 & A & \\
\hline 8 & 15 & 0.9415 & A & \\
\hline 1 & 15 & 0.9371 & $\mathrm{~A}$ & \\
\hline 2 & 15 & 0.9363 & A & \\
\hline 6 & 15 & 0.9272 & $\mathrm{~A}$ & B \\
\hline 9 & 15 & 0.9166 & & $\mathrm{~B} C$ \\
\hline 4 & 15 & 0.9116 & & C \\
\hline 10 & 15 & 0.9087 & & $\mathrm{C}$ \\
\hline 3 & 15 & 0.9040 & & $\mathrm{C}$ \\
\hline 5 & 15 & 0.9028 & & $\mathrm{C}$ \\
\hline
\end{tabular}

\section{RESULTR}

Fontes de Variação G.L. Soma de Quadrado Quadrado Médio $E$ Signif.

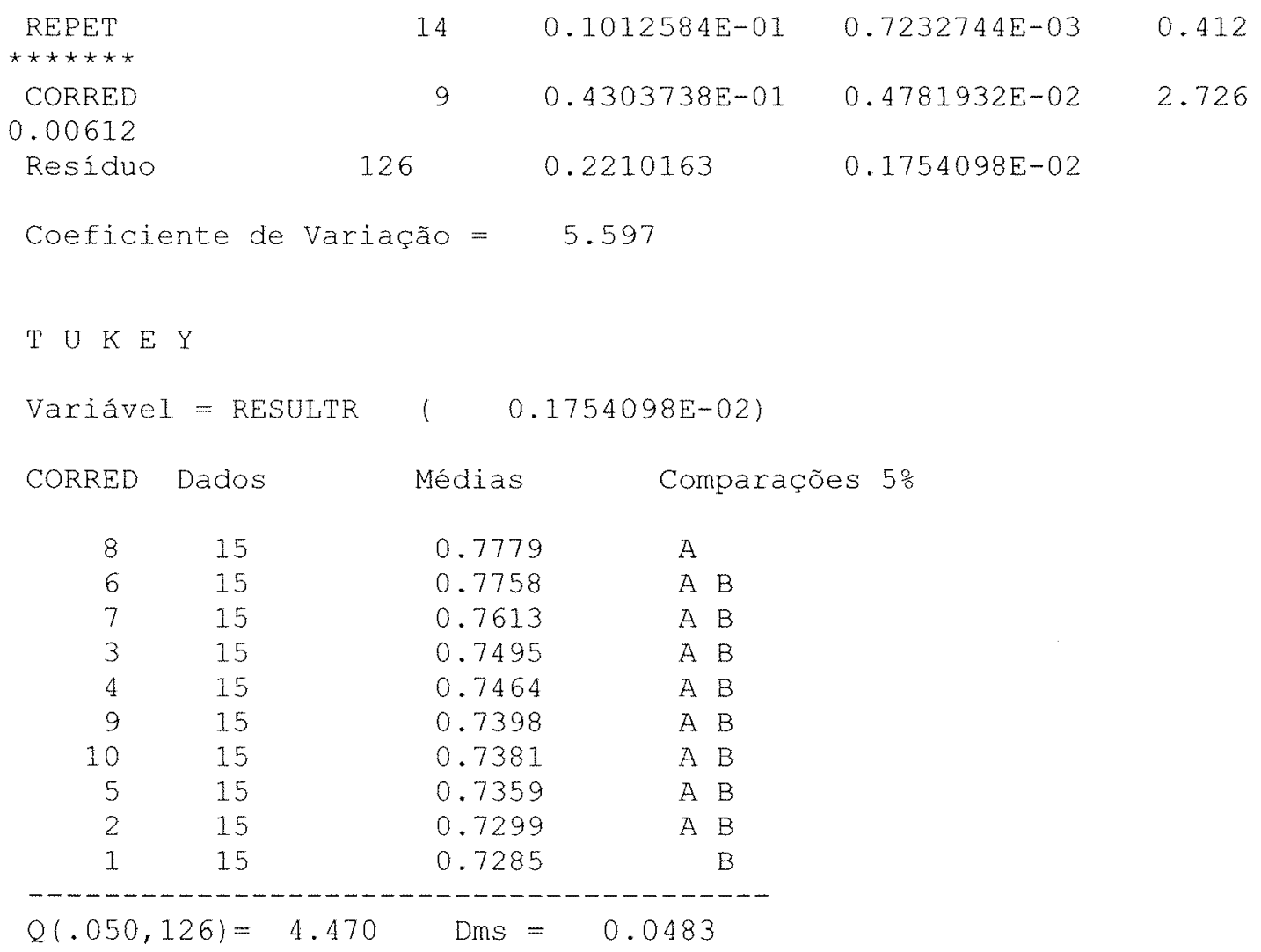




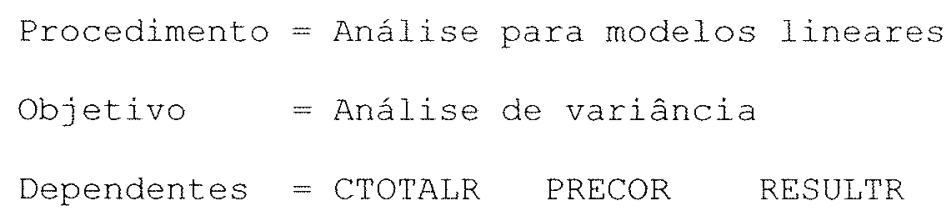


ANEXO C 
Tabela 51. Indicadores privados e sociais de propriedades leiteiras, corredor Piracanjuba.

\begin{tabular}{cccccc}
\hline Prop. Lucro Social & $\begin{array}{c}\text { Transf. } \\
\text { Líquida de } \\
\text { Politicas }\end{array}$ & $\begin{array}{c}\text { Coeficiente } \\
\text { Proteção } \\
\text { Nominal }\end{array}$ & $\begin{array}{c}\text { Coeficiente } \\
\text { Proteção } \\
\text { Efetiva }\end{array}$ & $\begin{array}{c}\text { Desestímulo aos } \\
\text { Agentes }\end{array}$ \\
\hline 001 & 0,21 & $-0,15$ & 0,73 & 0,50 & $-0,29$ \\
002 & 0,26 & $-0,16$ & 0,69 & 0,54 & $-0,32$ \\
003 & 0,30 & $-0,24$ & 0,56 & 0,39 & $-0,47$ \\
004 & 0,24 & $-0,21$ & 0,59 & 0,33 & $-0,43$ \\
005 & 0,30 & $-0,18$ & 0,65 & 0,53 & $-0,37$ \\
006 & 0,19 & $-0,12$ & 0,80 & 0,63 & $-0,24$ \\
007 & 0,17 & $-0,12$ & 0,76 & 0,57 & $-0,24$ \\
008 & 0,12 & $-0,21$ & 0,56 & 0,35 & $-0,44$ \\
009 & 0,27 & $-0,22$ & 0,55 & 0,38 & $-0,44$ \\
010 & 0,31 & $-0,23$ & 0,55 & 0,39 & $-0,45$ \\
011 & 0,26 & $-0,12$ & 0,78 & 0,64 & $-0,23$ \\
012 & 0,24 & $-0,24$ & 0,55 & 0,33 & $-0,48$ \\
013 & 0,26 & $-0,22$ & 0,58 & 0,43 & $-0,44$ \\
014 & 0,14 & $-0,13$ & 0,75 & 0,45 & $-0,26$ \\
015 & 0,18 & $-0,18$ & 0,63 & 0,37 & $-0,36$ \\
\hline
\end{tabular}

Fonte: Dados da pesquisa

Tabela 52. Indicadores privados e sociais de propriedades leiteiras, corredor Rio Verde.

\begin{tabular}{cccccc}
\hline Prop. & Lucro Social & $\begin{array}{c}\text { Transferência } \\
\text { Líquida de } \\
\text { Políticas }\end{array}$ & $\begin{array}{c}\text { Coeficiente } \\
\text { de Proteção } \\
\text { Nominal }\end{array}$ & $\begin{array}{c}\text { Coeficiente } \\
\text { de Proteção } \\
\text { Efetiva }\end{array}$ & $\begin{array}{c}\text { Desestímulo aos } \\
\text { Agentes }\end{array}$ \\
\hline 016 & 0,24 & $-0,19$ & 0,61 & 0,43 & $-0,39$ \\
017 & 0,17 & $-0,19$ & 0,63 & 0,26 & $-0,38$ \\
018 & 0,27 & $-0,18$ & 0,62 & 0,46 & $-0,35$ \\
019 & 0,30 & $-0,15$ & 0,70 & 0,61 & $-0,31$ \\
020 & 0,17 & $-0,20$ & 0,60 & 0,21 & $-0,41$ \\
021 & 0,30 & $-0,21$ & 0,58 & 0,41 & $-0,43$ \\
022 & 0,23 & $-0,22$ & 0,57 & 0,32 & $-0,43$ \\
023 & 0,21 & $-0,19$ & 0,60 & 0,35 & $-0,39$ \\
024 & 0,24 & $-0,26$ & 0,54 & 0,24 & $-0,45$ \\
025 & 0,32 & $-0,19$ & 0,62 & 0,51 & $-0,39$ \\
026 & 0,27 & $-0,19$ & 0,64 & 0,50 & $-0,38$ \\
027 & 0,26 & $-0,18$ & 0,65 & 0,48 & $-0,35$ \\
028 & 0,27 & $-0,22$ & 0,56 & 0,35 & $-0,45$ \\
029 & 0,25 & $-0,14$ & 0,72 & 0,59 & $-0,31$ \\
030 & 0,23 & 0,00 & 0,50 & 0,24 & $-0,46$ \\
\hline
\end{tabular}

Fonte: Dados da pesquisa 
Tabela 53. Indicadores privados e sociais de propriedades leiteiras, corredor Ibiá.

\begin{tabular}{cccccc}
\hline Prop. & Lucro Social & $\begin{array}{c}\text { Transferência } \\
\text { Líquida de } \\
\text { Políticas }\end{array}$ & $\begin{array}{c}\text { Coeficiente } \\
\text { de Proteção } \\
\text { Nominal }\end{array}$ & $\begin{array}{c}\text { Coeficiente de } \\
\text { Proteção } \\
\text { Efetiva }\end{array}$ & $\begin{array}{c}\text { Desestímulo aos } \\
\text { Agentes }\end{array}$ \\
\hline 031 & 0,24 & $-0,09$ & 0,82 & 0,73 & $-0,19$ \\
032 & 0,26 & $-0,09$ & 0,82 & 0,74 & $-0,19$ \\
033 & 0,21 & $-0,11$ & 0,78 & 0,61 & $-0,22$ \\
034 & 0,29 & $-0,12$ & 0,77 & 0,67 & $-0,23$ \\
035 & 0,20 & $-0,09$ & 0,81 & 0,65 & $-0,19$ \\
036 & 0,25 & $-0,14$ & 0,71 & 0,54 & $-0,29$ \\
037 & 0,20 & $-0,15$ & 0,69 & 0,45 & $-0,30$ \\
038 & 0,20 & $-0,10$ & 0,80 & 0,67 & $-0,21$ \\
039 & 0,25 & $-0,12$ & 0,76 & 0,62 & $-0,24$ \\
040 & 0,20 & $-0,14$ & 0,71 & 0,45 & $-0,28$ \\
041 & 0,15 & $-0,13$ & 0,76 & 0,55 & $-0,26$ \\
042 & 0,28 & $-0,14$ & 0,72 & 0,60 & $-0,29$ \\
043 & 0,23 & $-0,15$ & 0,70 & 0,49 & $-0,30$ \\
044 & 0,28 & $-0,17$ & 0,66 & 0,54 & $-0,35$ \\
045 & 0,30 & $-0,16$ & 0,68 & 0,55 & $-0,32$ \\
\hline
\end{tabular}

Fonte: Dados da pesquisa

Tabela 54. Indicadores privados e sociais de propriedades leiteiras, corredor Sete Lagoas .

\begin{tabular}{cccccc}
\hline Prop. & Lucro Social & $\begin{array}{c}\text { Transferência } \\
\text { Líquida de } \\
\text { Políticas }\end{array}$ & $\begin{array}{c}\text { Coeficiente } \\
\text { de Proteção } \\
\text { Nominal }\end{array}$ & $\begin{array}{c}\text { Coeficiente } \\
\text { de Proteção } \\
\text { Efetiva }\end{array}$ & $\begin{array}{c}\text { Subsídio às } \\
\text { Propriedades }\end{array}$ \\
\hline 046 & 0,23 & $-0,16$ & 0,70 & 0,45 & $-0,32$ \\
047 & 0,21 & $-0,13$ & 0,74 & 0,56 & $-0,26$ \\
048 & 0,17 & $-0,11$ & 0,77 & 0,53 & $-0,22$ \\
049 & 0,13 & $-0,12$ & 0,78 & 0,50 & $-0,23$ \\
050 & 0,46 & $-0,25$ & 0,60 & 0,50 & $-0,40$ \\
051 & 0,17 & $-0,13$ & 0,75 & 0,48 & $-0,26$ \\
052 & 0,31 & $-0,27$ & 0,55 & 0,31 & $-0,45$ \\
053 & 0,20 & $-0,13$ & 0,74 & 0,53 & $-0,26$ \\
054 & 0,17 & $-0,11$ & 0,78 & 0,52 & $-0,22$ \\
055 & 0,28 & $-0,11$ & 0,78 & 0,66 & $-0,22$ \\
056 & 0,16 & $-0,13$ & 0,72 & 0,37 & $-0,27$ \\
057 & 0,28 & $-0,12$ & 0,75 & 0,62 & $-0,25$ \\
058 & 0,15 & $-0,16$ & 0,67 & 0,24 & $-0,32$ \\
059 & 0,24 & $-0,11$ & 0,77 & 0,65 & $-0,22$ \\
060 & 0,17 & $-0,12$ & 0,77 & 0,51 & $-0,23$ \\
\hline
\end{tabular}

Fonte: Dados da pesquisa 
Tabela 55. Indicadores privados e sociais de propriedades leiteiras, corredor Jundiaí.

\begin{tabular}{cccccc}
\hline Prop. & Lucro Social & $\begin{array}{c}\text { Transferência } \\
\text { Líquida de } \\
\text { Políticas }\end{array}$ & $\begin{array}{c}\text { Coeficiente } \\
\text { de Proteção } \\
\text { Nominal }\end{array}$ & $\begin{array}{c}\text { Coeficiente } \\
\text { de Proteção } \\
\text { Efetiva }\end{array}$ & $\begin{array}{c}\text { Desestímulo aos } \\
\text { Agentes }\end{array}$ \\
\hline 061 & 0,11 & $-0,12$ & 0,75 & 0,53 & $-0,25$ \\
062 & 0,11 & $-0,11$ & 0,77 & 0,47 & $-0,24$ \\
063 & 0,06 & $-0,11$ & 0,79 & 0,39 & $-0,22$ \\
064 & 0,11 & $-0,13$ & 0,70 & 0,27 & $-0,28$ \\
065 & 0,13 & $-0,17$ & 0,63 & 0,20 & $-0,36$ \\
066 & 0,17 & $-0,13$ & 0,74 & 0,53 & $-0,27$ \\
067 & 0,18 & $-0,10$ & 0,80 & 0,69 & $-0,20$ \\
068 & 0,14 & $-0,10$ & 0,75 & 0,61 & $-0,21$ \\
069 & 0,28 & $-0,10$ & 0,79 & 0,74 & $-0,20$ \\
070 & 0,29 & $-0,15$ & 0,65 & 0,52 & $-0,32$ \\
071 & 0,18 & $-0,05$ & 0,87 & 0,78 & $-0,12$ \\
072 & 0,25 & $-0,13$ & 0,72 & 0,58 & $-0,27$ \\
073 & 0,25 & $-0,14$ & 0,72 & 0,59 & $-0,29$ \\
074 & 0,08 & $-0,10$ & 0,78 & 0,53 & $-0,21$ \\
075 & 0,18 & $-0,14$ & 0,71 & 0,57 & $-0,29$ \\
\hline
\end{tabular}

Fonte: Dados da pesquisa

Tabela 56. Indicadores privados e sociais de propriedades leiteiras, corredor Ribeirão Preto.

\begin{tabular}{cccccc}
\hline Prop. & Lucro Social & $\begin{array}{c}\text { Transferência } \\
\text { Líquida de } \\
\text { Politicas }\end{array}$ & $\begin{array}{c}\text { Coeficiente } \\
\text { de Proteção } \\
\text { Nominal }\end{array}$ & $\begin{array}{c}\text { Coeficiente } \\
\text { de Proteção } \\
\text { Efetiva }\end{array}$ & $\begin{array}{c}\text { Desestímulo aos } \\
\text { Agentes }\end{array}$ \\
\hline 076 & 0,17 & $-0,13$ & 0,75 & 0,53 & $-0,26$ \\
077 & 0,10 & $-0,12$ & 0,77 & 0,40 & $-0,25$ \\
078 & 0,24 & $-0,16$ & 0,67 & 0,46 & $-0,33$ \\
079 & 0,24 & $-0,11$ & 0,78 & 0,63 & $-0,22$ \\
080 & 0,14 & $-0,09$ & 0,81 & 0,60 & $-0,19$ \\
081 & 0,28 & $-0,12$ & 0,75 & 0,64 & $-0,25$ \\
082 & 0,12 & $-0,13$ & 0,77 & 0,46 & $-0,26$ \\
083 & 0,20 & $-0,20$ & 0,60 & 0,22 & $-0,40$ \\
084 & 0,17 & $-0,11$ & 0,78 & 0,56 & $-0,23$ \\
085 & 0,07 & $-0,12$ & 0,77 & 0,33 & $-0,25$ \\
086 & 0,15 & $-0,12$ & 0,77 & 0,53 & $-0,24$ \\
087 & 0,16 & $-0,17$ & 0,68 & 0,41 & $-0,35$ \\
088 & 0,13 & $-0,12$ & 0,77 & 0,50 & $-0,25$ \\
089 & 0,20 & $-0,17$ & 0,65 & 0,39 & $-0,35$ \\
090 & 0,22 & $-0,13$ & 0,75 & 0,60 & $-0,26$ \\
\hline
\end{tabular}

Fonte: Dados da pesquisa 
Tabela 57. Indicadores privados e sociais de propriedades leiteiras, corredor Carambeí.

\begin{tabular}{cccccc}
\hline Prop. & Lucro Social & $\begin{array}{c}\text { Transferência } \\
\text { Líquida de } \\
\text { Políticas }\end{array}$ & $\begin{array}{c}\text { Coeficiente } \\
\text { de Proteção } \\
\text { Nominal }\end{array}$ & $\begin{array}{c}\text { Coeficiente } \\
\text { de Proteção } \\
\text { Efetiva }\end{array}$ & $\begin{array}{c}\text { Desestímulo aos } \\
\text { Agentes }\end{array}$ \\
\hline 091 & 0,14 & $-0,13$ & 0,71 & 0,46 & $-0,26$ \\
092 & 0,30 & $-0,17$ & 0,68 & 0,54 & $-0,33$ \\
093 & 0,28 & $-0,15$ & 0,70 & 0,55 & $-0,30$ \\
094 & 0,24 & $-0,15$ & 0,70 & 0,50 & $-0,31$ \\
095 & 0,20 & $-0,14$ & 0,73 & 0,50 & $-0,27$ \\
096 & 0,25 & $-0,15$ & 0,69 & 0,51 & $-0,31$ \\
097 & 0,30 & $-0,16$ & 0,70 & 0,57 & $-0,31$ \\
098 & 0,32 & $-0,16$ & 0,69 & 0,58 & $-0,32$ \\
099 & 0,28 & $-0,14$ & 0,74 & 0,62 & $-0,27$ \\
100 & 0,27 & $-0,14$ & 0,71 & 0,54 & $-0,29$ \\
101 & 0,31 & $-0,16$ & 0,69 & 0,55 & $-0,31$ \\
102 & 0,18 & $-0,16$ & 0,68 & 0,32 & $-0,32$ \\
103 & 0,33 & $-0,15$ & 0,69 & 0,59 & $-0,30$ \\
104 & 0,32 & $-0,15$ & 0,71 & 0,62 & $-0,29$ \\
105 & 0,25 & $-0,14$ & 0,72 & 0,54 & $-0,28$ \\
\hline
\end{tabular}

Fonte: Dados da pesquisa

Tabela 58. Indicadores privados e sociais de propriedades leiteiras, corredor Mal. Cândido Rondon.

\begin{tabular}{cccccc}
\hline Prop. & Lucro Social & $\begin{array}{c}\text { Transferência } \\
\text { Líquida de } \\
\text { Políticas }\end{array}$ & $\begin{array}{c}\text { Coeficiente } \\
\text { de Proteção } \\
\text { Nominal }\end{array}$ & $\begin{array}{c}\text { Coeficiente de } \\
\text { Proteção } \\
\text { Efetiva }\end{array}$ & $\begin{array}{c}\text { Desestímulo aos } \\
\text { Agentes }\end{array}$ \\
\hline 106 & 0,24 & $-0,21$ & 0,60 & 0,29 & $-0,41$ \\
107 & 0,21 & $-0,20$ & 0,60 & 0,30 & $-0,40$ \\
108 & 0,29 & $-0,21$ & 0,59 & 0,41 & $-0,41$ \\
109 & 0,22 & $-0,19$ & 0,63 & 0,35 & $-0,37$ \\
110 & 0,23 & $-0,21$ & 0,58 & 0,31 & $-0,41$ \\
111 & 0,27 & $-0,21$ & 0,58 & 0,38 & $-0,41$ \\
112 & 0,24 & $-0,20$ & 0,60 & 0,35 & $-0,40$ \\
113 & 0,30 & $-0,20$ & 0,59 & 0,44 & $-0,40$ \\
114 & 0,30 & $-0,21$ & 0,58 & 0,42 & $-0,42$ \\
115 & 0,29 & $-0,21$ & 0,59 & 0,42 & $-0,42$ \\
116 & 0,22 & $-0,22$ & 0,59 & 0,31 & $-0,43$ \\
117 & 0,28 & $-0,21$ & 0,59 & 0,42 & $-0,40$ \\
118 & 0,20 & $-0,19$ & 0,61 & 0,30 & $-0,39$ \\
119 & 0,21 & $-0,20$ & 0,61 & 0,28 & $-0,39$ \\
120 & 0,28 & $-0,21$ & 0,58 & 0,36 & $-0,42$ \\
\hline
\end{tabular}

Fonte: Dados da pesquisa 
Tabela 59. Indicadores privados e sociais de propriedades leiteiras, corredor Teutônia.

\begin{tabular}{cccccc}
\hline Prop. & Lucro Social & $\begin{array}{c}\text { Transferência } \\
\text { Líquida de } \\
\text { Políticas }\end{array}$ & $\begin{array}{c}\text { Coeficiente de } \\
\text { Proteção } \\
\text { Nominal }\end{array}$ & $\begin{array}{c}\text { Coeficiente } \\
\text { de Proteção } \\
\text { Efetiva }\end{array}$ & $\begin{array}{c}\text { Desestímulo aos } \\
\text { Agentes }\end{array}$ \\
\hline 121 & 0,28 & $-0,17$ & 0,64 & 0,48 & $-0,36$ \\
122 & 0,24 & $-0,15$ & 0,69 & 0,47 & $-0,30$ \\
123 & 0,27 & $-0,17$ & 0,66 & 0,49 & $-0,34$ \\
124 & 0,25 & $-0,18$ & 0,63 & 0,39 & $-0,37$ \\
125 & 0,24 & $-0,23$ & 0,54 & 0,29 & $-0,45$ \\
126 & 0,28 & $-0,18$ & 0,65 & 0,45 & $-0,36$ \\
127 & 0,29 & $-0,20$ & 0,60 & 0,38 & $-0,39$ \\
128 & 0,29 & $-0,17$ & 0,67 & 0,46 & $-0,32$ \\
129 & 0,34 & $-0,21$ & 0,58 & 0,45 & $-0,42$ \\
130 & 0,25 & $-0,19$ & 0,63 & 0,41 & $-0,37$ \\
131 & 0,28 & $-0,21$ & 0,58 & 0,38 & $-0,42$ \\
132 & 0,30 & $-0,22$ & 0,55 & 0,38 & $-0,45$ \\
133 & 0,30 & $-0,19$ & 0,61 & 0,45 & $-0,39$ \\
134 & 0,27 & $-0,19$ & 0,62 & 0,41 & $-0,38$ \\
135 & 0,36 & $-0,21$ & 0,58 & 0,49 & $-0,41$ \\
\hline
\end{tabular}

Fonte: Dados da pesquisa

Tabela 60 . Indicadores privados e sociais de propriedades leiteiras, corredor Carazinho.

\begin{tabular}{cccccc}
\hline Prop. & Lucro Social & $\begin{array}{c}\text { Transferência } \\
\text { Líquida de } \\
\text { Políticas }\end{array}$ & $\begin{array}{c}\text { Coeficiente } \\
\text { de Proteção } \\
\text { Nominal }\end{array}$ & $\begin{array}{c}\text { Coeficiente } \\
\text { de Proteção } \\
\text { Efetiva }\end{array}$ & $\begin{array}{c}\text { Desestímulo aos } \\
\text { Agentes }\end{array}$ \\
\hline 136 & 0,30 & $-0,19$ & 0,64 & 0,48 & $-0,37$ \\
137 & 0,31 & $-0,21$ & 0,57 & 0,39 & $-0,43$ \\
138 & 0,29 & $-0,22$ & 0,56 & 0,31 & $-0,44$ \\
139 & 0,27 & $-0,21$ & 0,57 & 0,42 & $-0,42$ \\
140 & 0,31 & $-0,19$ & 0,62 & 0,49 & $-0,38$ \\
141 & 0,17 & $-0,17$ & 0,64 & 0,35 & $-0,35$ \\
142 & 0,28 & $-0,19$ & 0,62 & 0,46 & $-0,37$ \\
143 & 0,28 & $-0,11$ & 0,77 & 0,64 & $-0,22$ \\
144 & 0,25 & $-0,14$ & 0,71 & 0,51 & $-0,28$ \\
145 & 0,24 & $-0,20$ & 0,60 & 0,34 & $-0,39$ \\
146 & 0,19 & $-0,17$ & 0,64 & 0,30 & $-0,35$ \\
147 & 0,26 & $-0,19$ & 0,61 & 0,41 & $-0,38$ \\
148 & 0,29 & $-0,18$ & 0,66 & 0,49 & $-0,34$ \\
149 & 0,24 & $-0,20$ & 0,58 & 0,38 & $-0,41$ \\
150 & 0,18 & $-0,20$ & 0,57 & 0,17 & $-0,41$ \\
\hline
\end{tabular}

Fonte: Dados da pesquisa 
ANEXO D 


\begin{tabular}{|llrrrr|}
\hline \multicolumn{1}{|c}{ Corredores } & & Receitas & \multicolumn{2}{c}{ Custos } & Lucros \\
\cline { 3 - 4 } & & & Transacionáveis & Fatores & \\
\hline Piracanjuba & Privados & 0,788 & 0,467 & 0,111 & 0,210 \\
& Sociais & 0,822 & 0,468 & 0,106 & 0,248 \\
& Divergência & $-0,034$ & $-0,001$ & 0,005 & $-0,038$ \\
\hline Rio Verde & Privados & 0,788 & 0,445 & 0,103 & 0,240 \\
& Sociais & 0,821 & 0,450 & 0,097 & 0,274 \\
& Divergência & $-0,033$ & $-0,005$ & 0,006 & $-0,034$ \\
\hline Ibiá & Privados & 0,788 & 0,475 & 0,094 & 0,219 \\
& Sociais & 0,805 & 0,477 & 0,088 & 0,240 \\
& Divergência & $-0,017$ & $-0,002$ & 0,006 & $-0,021$ \\
\hline Sete Lagoas & Privados & 0,788 & 0,507 & 0,088 & 0,193 \\
& Sociais & 0,816 & 0,510 & 0,086 & 0,220 \\
& Divergência & $-0,028$ & $-0,003$ & 0,002 & $-0,027$ \\
\hline Jundiaí & Privados & 0,788 & 0,479 & 0,113 & 0,196 \\
& Sociais & 0,783 & 0,485 & 0,058 & 0,240 \\
& Divergência & 0,005 & $-0,006$ & 0,055 & $-0,044$ \\
\hline Ribeirão Preto & Privados & 0,788 & 0,511 & 0,099 & 0,178 \\
& Sociais & 0,794 & 0,513 & 0,089 & 0,192 \\
& Divergência & $-0,006$ & $-0,002$ & 0,010 & $-0,014$ \\
\hline Castro & Privados & 0,788 & 0,437 & 0,075 & 0,276 \\
& Sociais & 0,803 & 0,438 & 0,070 & 0,295 \\
& Divergência & $-0,015$ & $-0,001$ & 0,005 & $-0,019$ \\
\hline Mal. Cândido & Privados & 0,788 & 0,477 & 0,084 & 0,227 \\
Rondon & Sociais & 0,824 & 0,479 & 0,082 & 0,263 \\
& Divergência & $-0,036$ & $-0,002$ & 0,002 & $-0,036$ \\
\hline Teutônia & Privados & 0,788 & 0,455 & 0,080 & 0,253 \\
& Sociais & 0,829 & 0,456 & 0,078 & 0,295 \\
& Divergência & $-0,041$ & $-0,001$ & 0,002 & $-0,042$ \\
\hline Carazinho & Privados & 0,788 & 0,462 & 0,078 & 0,248 \\
& Sociais & 0,823 & 0,464 & 0,068 & 0,291 \\
& Divergência & $-0,035$ & $-0,002$ & 0,010 & $-0,043$ \\
\hline
\end{tabular}

Quadro 9 - Matriz de Análise Política, Leite Longa Vida, por corredor.

Fonte: Dados da pesquisa 


\begin{tabular}{|c|c|c|c|c|c|}
\hline Corredore & & Receitas & Custos & & Lucros \\
\hline & & & Transacionáveis & Fatores & \\
\hline Piracanjuba & Privados & 5,88 & 2,67 & 1,13 & 2,08 \\
\hline & Sociais & 9,36 & 2,65 & 1,11 & 5,60 \\
\hline & Divergência & $-3,48$ & 0,02 & 0,02 & $-3,52$ \\
\hline Rio Verde & Privados & 5,88 & 2,41 & 1,06 & 2,41 \\
\hline & Sociais & 9,36 & 2,42 & 1,03 & 5,91 \\
\hline & Divergência & $-3,48$ & $-0,01$ & 0,03 & $-3,50$ \\
\hline Ibiá & Privados & 5,88 & 2,81 & 0,95 & 2,12 \\
\hline & Sociais & 9,34 & 2,80 & 0,89 & 5,65 \\
\hline & Divergência & $-3,46$ & 0,01 & 0,06 & $-3,53$ \\
\hline Sete Lagoas & Privados & 5,88 & 3,19 & 0,89 & 1,80 \\
\hline & Sociais & 9,35 & 3,18 & 0,90 & 5,27 \\
\hline & Divergência & $-3,47$ & 0,01 & $-0,01$ & $-3,47$ \\
\hline Jundiaí & Privados & 5,88 & 2,92 & 1,26 & 1,70 \\
\hline & Sociais & 9,33 & 2,96 & 1,18 & 5,19 \\
\hline & Divergência & $-3,45$ & $-0,04$ & 0,08 & $-3,49$ \\
\hline Ribeirão Preto & Privados & 5,88 & 3,27 & 1,04 & 1,57 \\
\hline & Sociais & 9,38 & 3,25 & 0,97 & 5,16 \\
\hline & Divergência & $-3,40$ & 0,02 & 0,07 & $-3,49$ \\
\hline Castro & Privados & 5,88 & 2,35 & 0,74 & 2,79 \\
\hline & Sociais & 9,34 & 2,33 & 0,68 & 6,33 \\
\hline & Divergência & $-3,46$ & 0,02 & 0,06 & $-3,54$ \\
\hline Mal. Cândido & Privados & 5,88 & 2,78 & 0,81 & 2,29 \\
\hline Rondon & Sociais & 9,36 & 2,76 & 0,78 & 5,82 \\
\hline & Divergência & $-3,48$ & 0,02 & 0,03 & $-3,53$ \\
\hline Teutônia & Privados & 5,88 & 2,51 & 0,78 & 2,59 \\
\hline & Sociais & 9,37 & 2,49 & 0,77 & 6,11 \\
\hline & Divergência & $-3,49$ & 0,02 & 0,01 & $-3,52$ \\
\hline Carazinho & Privados & 5,88 & 2,61 & 0,78 & 2,49 \\
\hline & Sociais & 9,36 & 2,59 & 0,79 & 5,98 \\
\hline & Divergência & $-3,48$ & 0,02 & $-0,01$ & $-3,49$ \\
\hline
\end{tabular}

Quadro 10 - Matriz de Análise Política, Leite em Pó, por corredor.

Fonte: Dados da pesquisa 
ANEXO E 


\begin{tabular}{|l|ccc|ccc|}
\hline \multirow{2}{*}{ Corredores } & \multicolumn{3}{|c|}{ Leite Longa Vida } & \multicolumn{3}{c|}{ Leite em Pó } \\
\cline { 2 - 6 } & $\begin{array}{c}\text { Lucro da } \\
\text { Cadeia (R\$) }\end{array}$ & $\begin{array}{c}\text { Primeiro } \\
\text { Elo (\%) }\end{array}$ & $\begin{array}{c}\text { Demais } \\
\text { Elos (\%) }\end{array}$ & $\begin{array}{c}\text { Lucro da } \\
\text { Cadeia } \\
\text { (R\$) }\end{array}$ & $\begin{array}{c}\text { Primeiro } \\
\text { Elo (\%) }\end{array}$ & $\begin{array}{c}\text { Demais } \\
\text { Elos (\%) }\end{array}$ \\
\hline Piracanjuba & 110 & 30,0 & 70,0 & 128 & 16,2 & 83,8 \\
Rio Verde & 120 & 37,5 & 62,5 & 162 & 17,5 & 82,5 \\
Ibiá & 98 & 95,9 & 04,1 & 118 & 50,1 & 49,9 \\
Sete Lagoas & 78 & 84,6 & 15,4 & 75 & 55,3 & 44,7 \\
Jundiaí & 152 & 25,0 & 75,0 & 133 & 18,0 & 82,0 \\
Rib. Preto & 133 & 21,8 & 78,2 & 117 & 15,6 & 84,4 \\
Castro & 153 & 78,4 & 21,6 & 182 & 41,5 & 58,5 \\
Mal. Rondon & 105 & 34,3 & 65,7 & 133 & 17,0 & 83,0 \\
Teutônia & 212 & 36,8 & 63,2 & 228 & 18,5 & 81,5 \\
Carazinho & 203 & 34,0 & 66,0 & 214 & 20,0 & 80,0 \\
\hline
\end{tabular}

Quadro 11 - Lucros consolidados e a partição entre produtores e demais elos das cadeias produtivas do Leite Longa Vida e Leite em Pó, por mil litros, por corredores.

Fonte: Dados da pesquisa 


\section{REFERÊNCIAS BIBLIOGRÁFICAS}

AGRICULTURAL AND FOOD POLICY CENTER - AFPC. Farm level consequences of canadian and U.S. dairy policies. College Station: Texas A\&M University, 1997. 18p. (Working paper, 97-8)

ALSTON, L.J. A framework for understanding the new Institutional economics (compact disc). In: SEMINÁRIO BRASILEIRO SOBRE NOVA ECONOMIA DAS INSTITUIÇÕES, 1., São Paulo, 1998. Anais. São Paulo: USP, 1998. $22 p$.

ALVES, J.M. Competitividade e tendência da produção de manga para exportação do nordeste do Brasil. Piracicaba, 2002. 144p. Tese (Doutorado)

- Escola Superior de Agricultura "Luiz de Queiroz", Universidade de São Paulo.

ANESINA, A.A.; COULIBALY, O.N. Policy and competitiveness of agroforesrybased technologies for maize production in Cameroon: an application of policy analysis matrix. Agricultural Economics, v.19, n.1-2, p.1-13, 1998.

ARAÚJO, J.G.F. Adoção de tecnologia e eficiência da exploração leiteira no município de Leopoldina-MG. Viçosa, 1981. 60p. Dissertação (M.S.) Universidade Fderal de Viçosa.

ARAÚJJO, C.M.M. Estratégias contratuais indústria-produtor de leite no estado de Minas Gerais. Viçosa, 1999. 88p. Dissertação (M.S.) - Universidade Federal de Viçosa. 
BAILEY, K.W. Marketing and pricing of milk and dairy products in the United States. Ames: lowa State University Press, 1997. 281p.

BARROSO, N.A. Análise do uso e distribuição dos recursos nas empresas rurais das Zonas de Meia Ponte e Mato Grosso de Goiás. Viçosa, 1968. 94p. Dissertação (M.S.) - Universidade Federal de Viçosa.

BARRICHELLO, R.R. The canadian dairy industry: prospects for future trade. Canadian Journal of Agricultural Economics, v.47, p.45-55, 1999.

BARROS, G.S.C.; BACCHI, M.R.P.; GALAN, V.B. Influência das importações nos preços do leite no mercado brasileiro (compact disc). In: CONGRESSO BRASILEIRO DE ECONOMIA E SOCIOLOGIA RURAL, 38., Rio de Janeiro, 2000. Anais. Brasilia: SOBER, 2000.

BENJAMIN, C.; GOHIN, A.; GUYOMARD, H.O. Future of european union dairy policy. Canadian Journal of Agricultural Economics, v.47, p.91-101, 1999.

BOTELHO, M. Sistema de recolha do leite a granel. Revista do Instituto de Laticínios Cândido Tostes, v.52(5), n.300, p.94-98, jul./dez. 1997.

BOUAMARA, Z.; RÉQUILLART, V. Agricultural policy in a vertical structure of production with an application to the milk industry. Paris: INRA, 1998. 14p.

BRANDÃO, A.S.P.; LEITE, J.L.B. Características principais do comércio internacional de leite. In: GOMES, A.T.; LEITE, J.L.B.; CARNEIRO, A.V. (Ed.). O agronegócio do leite no Brasil. Juiz de Fora: Embrapa Gado de Leite, 2001. p.167-180. 
BROOKS, B. Alternative view of the dairy outlook and industry issues. In: Agricultural outlook forum. Washington: USDA, 2001. http://www.usda.gov/oce/waob/oc2002/ program.htm (24 Oct. 2002)

CALEGAR, G.M. Competitividade dos produtos lácteos brasileiros: o caso do estado de Goiás. In: VIEIRA, R.C.M.T.; TEIXEIRA FILHO, A.R.; OLIVEIRA, J.; LOPES, M.R. (Ed.). Cadeias produtivas no Brasil: análise da competitividade. Brasília: Embrapa; Rio de Janeiro: Fundação Getúlio Vargas, 2001. p.205-238.

CAMPOS, B.R. Fatores externos determinantes da competitividade da cadeia agroindustrial do leite. Viçosa, 2001. 76p. Dissertação (M.S.) - Universidade Federal de Viçosa.

CASALI, A.S.D. Análise da estacionalidade da produção de leite na Zona da Mata-MG. Viçosa, 1981. 73p. Dissertação (M.S.) - Universidade Federal de Viçosa.

CASTRO, M.C.D.; NEVES, B.S. Análise da evolução recente e perspectivas da indústria laticinista no Brasil. In: GOMES, A.T.; LEITE, J.L.B.; CARNEIRO, A.V. (Ed.). O agronegócio do leite no Brasil. Juiz de Fora: Embrapa Gado de Leite, 2001. p.63-72.

CARDWELL, M. Milk quotas: European Comunity and United Kingdon law. Oxford: Clarendon Press Oxford, 1996. 220p.

COCHRANE, W.W. Farm prices: myth and reality. Minneapolis: University of Minnessota Press, 1958. 328p.

COX, T.; CHAVAS, J.P. Interregional analysis of the impacts of deregulation on U.S. dairy sector. Madison: University of Wisconsin, 1998. 10p. 
CROPP, R. The canadian dairy industry: prospects for future trade: discussion. Canadian Journal of Agriculture Economics, v.47, p.57-58, 1999.

CRUZ, F.J.C.; TEIXEIRA, E.C.; RAGGI, L.A. Análise da competitividade do leite no Mercosul. Revista de Economia e Sociologia Rural, v.31, n.3, p.17-31, 1993.

DELGADO, C.; ROSEGRANT, M.; STEINFELD, H.; EHUI, S.; COURBOIS, C. Livestock to 2020 the next food revolution. Rome: Food, Agriculture and the Enviroment; Washington: International Food Policy Research Institute, 1999. 85p. (Discussion paper, 28)

DELGADO, C.; NARROT, C. Impact of changing market forces and policies on structural change in the livestock industries of selected fastgrowing developing countries: final research report of phase. Rome: FAO, 2002. 118p.

DE JANVRY, A. Social structure and based technical change in Argentine agriculture. In: BISWANGER, H.P.; RUTTAN, V.W. (Ed.). Induced inovations. Baltimore: The Johns Hopkins University Press, 1978. p.297326.

DE JANVRY, A.; KEY, N.; SADOULET, E. Agricultural and rural development policy in Latin America: new directions and new challenges. Berkeley: University of California at Berkeley, 1997. 43p. (Working paper, 815)

DE NIGRI, J.A. As empresas multinacionais e a reestruturação do complexo lácteo brasileiro nos anos 90 (compact disc). In: CONGRESSO BRASILEIRO DE ECONOMIA E SOCIOLOGIA RURAL, 35., Natal, 1997. Anais. Brasilia: SOBER, 1997. 
DORNELAS, S. A coleta a granel de leite refrigerado e suas implicações sobre as relações contratuais entre o produtor e indústria: um estudo de caso. Piracicaba, 2000. 128p. Dissertação (M.S.) - Escola Superior de Agricultura "Luiz de Queiroz", Universidade de São Paulo.

ENGLER, J.J. Análise da produtividade de recursos na agricultura. Piracicaba, 1968. 102p. Dissertação (M.S.) - Escola Superior de Agricultura "Luiz de Queiroz", Universidade de São Paulo.

\section{EMBRAPA GADO DE LEITE. Leite em números.}

http://www.cnpgl.embrapa.br/leiteemnumeros (15 jun. 2001)

FARINA, E.M.M.Q. A regulamentação do mercado de leite e laticínios no Brasil. São Paulo: IPE, 1983. 119p.

FARINA, E.M.M.Q. Cadeias de produção e negociação de preços. In: SEMINÁRIO: AS COOPERATIVAS E A PRODUÇÃO DE LEITE NO ANO 2000, Belo Horizonte, 1995. Anais. Belo Horizonte: OCEMG, 1995. p.29-40.

FARINA, E.M.M.Q. Regulamentação, política antitruste e política industrial. In: FARINA, E.M.M.Q.; AZEVEDO, P.F.; SAES, M.S.M. Competitividade: mercado, estado e organizações. São Paulo: Singular, 1997. p.115-162.

FARIA, V.P. Produção e cooperativas de produtores de leite no Brasil. In: SEMINÁRIO: AS COOPERATIVAS E A PRODUÇÃO DE LEITE NO ANO 2000, Belo Horizonte, 1995. Anais. Belo Horizonte: OCEMG, 1995. p.56-70.

FEHÉR, I.; PAPP, Z. Analysing competitiveness of the hungarian agro-food chain (compact disc). In: EUROPEAN ASSOCIATION OF AGRICULTURAL ECONOMIST CONGRESS, 10., Saragoza, 2002. Proceedings. Rome: EAAE, 2002. 
FERREIRA, L.R. Taxa de câmbio e política cambial no Brasil. Rio de Janeiro: UERJ, 2002. 56p.

FERREIRA SOBRINHO, F.; COUTINHO, G.H.; COURA, J.D. Coleta de leite a granel. Belo Horizonte: Fundação João Pinheiro, 1995. 108p.

GALAN, V.B. Formas de governança e o cooperativismo do leite no Brasil: uma análise de setor, de casos escolhidos e de incentivos. São Paulo, 2000. 144p. Dissertação (M.S.) - Faculdade de Economia, Administração e Contabilidade, Universidade de São Paulo.

GOMES, S.T.; MELLO, R.P.; MARTINS, P.C. O custo da produção de leite. Brasília: Ministério da Agricultura, 1989. 66p.

GONÇALVES, R.; BAUMANN, R.; PRADO, L.C.D.; CANUTO, O. A nova economia internacional: uma perspectiva brasileira. Rio de Janeiro: Campus, 1998. 392p.

GUYOMARD, H.; MAHE, L.P.; ROE, T.L.; TARDITI, S. The CAP reform and EC-US relations: the GATT as a "CAP" on the CAP. Minneapolis: University of Minnesota, 1993. 36p. (Working paper, 93-6)

HADDAD, P.R. A competitividade do agronegócio e o desenvolvimento regional no Brasil. Brasilia: Embrapa, 1999. 293p.

HAMMOND, J.W. U.S. government intervention in dairy markets: has the 1996 agricultural act reformed the government's role ? Minneapolis: University of Minnesota, 1993. 36p. (Working paper, 96-4)

HILL, D.J.; PIGGOTT, R.R.; GRIFFITH, G.R. Profilability of incremental generic promotion expenditure by Australian dairy farmers. Armidale: University of New England, 1999. 28p. (Working paper, 99-8) 
HOFFMANN, R.; ENGLER, J.S. de C.; SERRANO, O.; THAME, A.C. de M.; NEVES, E.M. Administração da empresa agrícola. São Paulo: Pioneira, 1976. 327p.

HOFFMANN, R. Estatística para economistas. São Paulo: Pioneira, 1980. $379 p$.

HOLANDA, N. Planejamento e projetos. Rio de Janeiro: APEC, 1975. p.236253.

INSTITUTO BRASILEIRO DE GEOGRAFIA E ESTATISSTICA - IBGE. Matriz de relações intersetoriais do Brasil 1996. http://www.ibge.gov.br (21 maio 2000a)

INSTITUTO BRASILEIRO DE GEOGRAFIA E ESTATÍSTICA - IBGE. Censo agropecuário 1995. http://www.ibge.gov.br (21 maio 2000b)

INSTITUTO BRASILEIRO DE GEOGRAFIA E ESTATÍSTICA - IBGE. Pesquisa de orçamentos familiares. http://www.ibge.gov.br (11 jun. 2002)

INSTITUTO GLOBAL McKINSEY. Produtividade no Brasil. São Paulo: Campus, 1999. p.213-221.

JANK, M.S.; FARINA, E.M.M.Q.; GALAN, V.B. O agribusiness do leite no Brasil. São Paulo: USP/PENSA, 1999. 108p.

JANK, M.S.; GALAN, V.B. Desafios do sistema agroindustrial do leite no Brasil. Preços Agrícolas, v.14, n.160, p.9-13, fev. 2000.

KARDEL, J. Tendências de mercado. In: CASTRO, M.C.D.; MARTINS, P.C. (Ed.). Organização da produção primária: um desafio para a indústria de laticínios. Juiz de Fora: Epamig/ILCT, 1999. p.80-84. 
KYDD, J.; PEARCE, R.; STOCKBRIDGE, M. The economic analysis of commodity systems: extending the policy analysis matrix to account for environmental effects and transactions costs. Agricultural Systems, v.55, p.323-345, 1997.

LARUE, B.; VEEMAN, M.; FULTON, M. Protection, price discrimination and inefficient trade: the case for real tariffication. Canadian Journal of Agricultural Economics, v.47, p.77-87, 1999.

LIPS, M.; RIEDER, P. Endogenous adjusted output quotas: the abolishment of the raw milk quota in the European Union (compact disc). In: EUROPEAN ASSOCIATION OF AGRICULTURAL ECONOMIST CONGRESS, 10., Saragoza, 2002. Proceedings. Rome: EAAE, 2002.

LOPES, M.R. O imposto compensatório sobre os subsídios na origem e prática de "dumping" nos mercados agrícolas: um estudo preliminar no caso do Brasil. In: TEIXEIRA, E.C.; AGUIAR, D.R.D. Comércio internacional e comercialização agrícola. Viçosa: UFV, 1995. p.67-98.

LOPES, M.R.; JANK, M.S. O setor leiteiro, a intervenção do Estado e o Mercosul: análise e proposta de estratégias políticas. São Paulo: Associação Brasileria dos Produtores de Leite B - ABPLB, 1992. 80p.

MAGALHÃES, C.A. Análise econômica da pecuária de leite em competição com outros empreendimentos agropecuários na Zona da Mata de Minas Gerais. Viçosa, 1971. 166p. Dissertação (M.S.) - Universidade Federal de Viçosa.

MARTINS, P.C. Relações de troca na pecuária leiteira na Zona da Mata de Minas Gerais. In: CONGRESSO BRASILEIRO DE ECONOMIA E SOCIOLOGIA RURAL, 24., Lavras, 1986. Anais. Brasilia: SOBER, 1986. p.120-122. 
MARTINS, P.C. Análise comparativa entre o sistema de produção de leite da Embrapa e sistemas de produção em fazendas do estado de Minas Gerais. Viçosa, 1987. 112p. Dissertação (M.S.) - Universidade Federal de Viçosa.

MARTINS, P.C. Efeitos de políticas públicas sobre a cadeia produtiva do leite em pó. In: VIEIRA, R.C.M.T.; TEIXEIRA FILHO, A.R.; OLIVEIRA, J.; LOPES, M.R. (Ed.). Cadeias produtivas no Brasil: análise da competitividade. Brasília: Embrapa; Rio de Janeiro: Fundação Getúlio Vargas, 2001. p.239-272.

MARTINS, P.C.; ARAÚJO, P.F.C. Inovação técnica e grupos de interesse no setor de lácteos brasileiro. In: CONGRESSO NACIONAL DE LATICÍNIOS, 17., Juiz de Fora, 2000. Anais. Juiz de Fora: ILCT, 2000. p.196-202.

MARTINS, P.C.; GUILHOTO, J.J.M. Leite e derivados e a geração de emprego, renda e ICMS no contexto da economia brasileira. In: GOMES, A.T.; LEITE, J.L.B.; CARNEIRO, A.V. (Ed.). O agronegócio do leite no Brasil. Juiz de Fora: Embrapa Gado de Leite, 2001. p.181-205

MARTINS, P.C.; GOMES, A.T. Mudança institucional: o grande desafio. In: Perspectivas e avanços em laticínios. Juiz de Fora: Epamig, 2000. p.77104.

MARTINS, P.C.; YAMAGUCHI, L.C.T. Globalização, política de estabilização e os reflexos no agronegócio do leite. In: AGUIAR, D.R.D.; PINHO, J.B. Agronegócio brasileiro: desafios e perspectivas. Brasília: SOBER, 1998. v.1. p.44-52.

MEIRELES, A.J. A (des)razão laticinista: a indústria de laticínios no último quartel do século XX. São Paulo: Cultura Editores Associados, 1996. 267p. 
MEIRELES, A.J.; ALVES, A. Importância do leite longa vida para o desenvolvimento do mercado brasileiro. In: GOMES, A.T.; LEITE, J.L.B.; CARNEIRO, A.V. (Ed.). O agronegócio do leite no Brasil. Juiz de Fora: Embrapa Gado de Leite, 2001. p.73-88.

MELLO, F.B.H. Prioridade agrícola: sucesso ou fracasso? São Paulo: Pioneira, 1985. 200p.

MELLO, F.B.H. A questão da produção e do abastecimento alimentar. Brasilia: Ministério do Planejamento, 1988. 59p.

MENDES, A.S. Estruturação e desafios do setor de produção de leite. In: CASTRO, M.C.D.; MARTINS, P.C. (Ed.). Organização da produção primária: um desafio para a indústria de laticínios. Juiz de Fora: Epamig/ILCT, 1999. p.40-44.

MILGROM, P.; ROBERTS, J. Economics, organization and management. London: Prentice Hall International Editions, 1994. 621p.

MONKE, E.; PEARSON, S.R. The policy analysis matrix for agricultural development. Ithaca: Cornell University Press, 1989. 279p.

MORICOCHI, L. Situação da pecuária leiteira em São Paulo. Agricultura em São Paulo, v.20, n.1/2, p.42, 1973.

NASCIMENTO, R.C. Investimento agroindustrial e capital estrangeiro no Brasil: caso do setor de laticínios. Viçosa, 1999. p.106. Dissertação (M.S.) Universidade Federal de Viçosa.

NASSER, B. Economia regional, desigualdade regional no Brasil e o estudo dos eixos nacionais de desenvolvimento. Revista do BNDES, v.7, n.14, p.145178, dez. 2000. 
NELSON, G.C.; PANGGABEAN, M. The costs of indonesian sugar policy: a policy analysis matrix approach. American Journal Agricultural Economics, v.57, p.703-712, Aug. 1991.

NEVES, M.F.; SPERS, E.E. Agribusiness: a origem, os conceitos e tendências na europa. In: MACHADO FILHO, C.A.P.; SPERS E.E.; CHADDAD, F.R.; NEVES, M.F. Agribusiness europeu. São Paulo: Pioneira, 1996. p.1-15.

NONNENBERG, M.J.B.; MENDONÇA, M.J.C. Criação e desvio de comércio no Mercosul: o caso dos produtos agrícolas. Revista de Economia e Sociologia Rural, v.38, n.1, p.65-85, jan./mar. 2000.

NORONHA, H.F.D. Análise econômica do uso de recursos na produção de leite, Vale do Paraiba, Estado de São Paulo, ano agrícola, 1972/1973. Viçosa, 1974. 50p. Dissertação (M.S.) - Universidade Federal de Viçosa.

NORONHA, J.F. Projetos agropecuários: administração financeira, orçamento e viabilidade econômica. São Paulo: Atlas, 1987. 269p.

NORTH, C.D. Institutions. Journal of Economic Perspectives, v.5, n.1, p.97112, Winter 1991.

ORGANIZAÇÃO PARA A COOPERAÇÃO E DESENVOLVIMENTO ECONÔMICO - OCDE. The Uruguay round: a preliminary evaluation of the impacts of the agreement on agriculture in the OECD countries. Paris: 1994, $116 p$.

PÉRES, F.C. Produtividade dos recursos na bacia leiteira de Brasilia, 1967/68: subsídios a um programa de crédito. Viçosa, 1974. 57p. Dissertação (M.S.) - Universidade Federal de Viçosa. 
PRITCHARD, W.N. The emerging contourns of the third food regime: evidence from australian dairy and wheat sectors. Economic Geography, v.47, n.1, p.64-75, 1998.

RAMSDEN, S.; GIBBONS, J.; WILSON, P. Impacts of changing relative prices on farm evel dairy production in the UK. Agricultural System, v.62, p.201215, 1999.

REIS, M.H.V.; REIS, R.P.; REIS, A.J. De Minas ou do Mercosul. Agroanalysis, v.18, n.2, p.13-15, fev. 1998.

RÉQUILLART, V. Domestic price regulations and trade policy: milk marketing orders in the United States: discussion. Canadian Journal of Agricultural Economics, v.47, p.17-18, 1999.

RODRIGUES, G.V. Estruturação e desafios do setor de produção de leite. In: CASTRO, M.C.D.; MARTINS, P.C. (Ed.). Organização da produção primária: um desafio para a indústria de laticínios. Juiz de Fora: Epamig/ILCT, 1999. p.36-40.

ROSADO, P.L. Competitividade e expansão da avicultura e suinocultura no contexto do Mercosul. Viçosa, 1997. 105p. Dissertação (M.S.) Universidade Federal de Viçosa.

SHARMA, R.; KONANDREAS, P. ; GREENFIELD J. An overview of assessment of the impact of the Uruguai Round on agricultural prices and incomes. Food Policy, v.21, n.4/5, p.351-363, 1996.

SILVA, I.C.V. Custos e otimização de rotas no transporte de leite a latão e a granel: um estudo de caso. Lavras, 1999. 71p. Dissertação (M.S.) Universidade Federal de Lavras. 
SILVA, C.A.B.; BATALHA, M.O. Competitividade em sistemas agroindustriais: metodologia e estudo de caso. In: NEVES, M.F.; AZEVEDO, P.F.; SAAB, M.S.M.; VAL, A.M.; CASTRO, L.T. II Workshop brasileiro de gestão de distemas agroalimentares. Ribeirão Preto: USP, 1999. p.9-20.

STAAL, S.J.; SHAPIRO, B.I. The effects of recent price liberalization on kenyan peri-urban dairy: a case study using the policy analysis matrix approach. Food Policy, v.19, n.6, p.553-549, 1994.

SUMNER, D.A. Domestic price regulations and trade policy: milk marketing orders in the United States. Canadian Journal of Agricultural Economics, v.47, p.5-16, 1999.

TSAKOK, I. Agricultural price policy: a practitioner's guide to partial: equilibrium analysis. Ithaca: Cornell University Press, 1990. 305p.

TEIXEIRA FILHO, A.R. Análise da produtividade marginal dos recursos agrícolas em dois municípios do Estado de Minas Gerais: Ituiutaba e Caratinga: no ano agrícola 1961/62. Viçosa, 1964. 102p. Dissertação (M.S.) - Universidade Federal de Viçosa.

TOLLINI, H. Produtividade marginal e uso dos recursos de funções de produção de leite em Leopoldina, MG. Viçosa, 1964. 89p. Dissertação (M.S.) Universidade Federal de Viçosa.

TUPY, O. Impacto de tecnologias de produção na lucratividade privada e econômica do segmento de leite pasteurizado tipo $B$ no estado de São Paulo. In: VIEIRA, R.C.M.T.; TEIXEIRA FILHO, A.R.; OLIVEIRA,J.; LOPES, M.R. (Ed.). Cadeias produtivas no Brasil: análise da competitividade. Brasília: Embrapa; Rio de Janeiro: Fundação Getúlio Vargas, 2001. p.273285. 
TURNBULL, A.D.A indústria leiteira da Nova Zelândia e o mercado global de laticínio. In: CASTRO, M.C.D. O agronegócio do leite e os alimentos funcionais. Juiz de Fora: Epamig/ILCT, 2001. p.17-34.

VEIGA, A. Uso e produtividade de recursos na agricultura: município de Jaguariuna, Estado de São Paulo. Agricultura em São Paulo, v.23, n.20, p.43-69, 1978.

VIEIRA, L.C. Efeitos de políticas públicas sobre a produção de milho, soja e trigo, no Brasil e na Argentina. Piracicaba, 1996. 104p. Dissertação (M.S.) Escola Superior de Agricultura "Luiz de Queiroz", Universidade de São Paulo.

YAO, S. Rice production in Thailand seen through a policy analysis matrix. Food Policy, v.22, n.6, p.547-560, 1997.

YAMAGUCHI, L.C.T.; MARTINS, P.C.; CARNEIRO, A.V. Produção de leite no Brasil nas três últimas décadas. In: GOMES, A.T.; LEITE, J.L.B.; CARNEIRO, A.V. (Ed.). O agronegócio do leite no Brasil. Juiz de Fora: Embrapa Gado de Leite, 2001. p.33-48

YAMAGUCHI, L.C.T.; CARNEIRO, A.V.; MARTINS, P.C. Custo da produção de leite: abrindo a caixa preta. Curvelo: Embrapa, 2002. 72p.

WSTHOFF, P.; BROWN, S.D. The U.S. dairy sector without prices supports. Canadian Journal of Agricultural Economics, v.47, p.19-27, 1999.

ZHU, Y.; COX, T.L.; CHAVAS, J.P. An economic analysis of the effects of the Uruguay round agreement and full trade liberalization on the word dairy sector. Canadian Journal of Agricultural Economics, v.47, p.187-200, 1999. 
ZYLBERSZTAJN, D. Estruturas de governança e coordenação do agribusiness: uma aplicação da Nova Economia das Instituições. São Paulo: USP, 1995. 86p.

ZYLBERSZTAJN, D. Entre o mercado e a hierarquia: análise de casos de quebra contratual no agribusiness. In: CONGRESSO DA SOCIEDADE BRASILEIRA DE ECONOMIA E SOCIOLOGIA RURAL, 34., Aracaju, 1996. Anais. Brasilia: SOBER, 1996. p.671-688.

ZOBBE, $\mathrm{H}$. The economic and historical foundation of the common agricultural policy in Europe (compact disc). In: EUROPEAN ASSOCIATION OF AGRICULTURAL ECONOMIST CONGRESS, 10., Saragoza, 2002. Proceedings. Rome: EAAE, 2002.

WEYERBROCK, S. Reform of european union: common agricultural policy: how to reach GATT: compatibility? European Economic Review, v.42, p.375$411,1998$.

WILLIAMSON, O. Transaction costs economics. In: SCHMALENSEE, R.; WILLIG, R.D. Handbook of industrial organization. New York: Elsevier Science, 1989. p.136-178. 